\title{
Analysis of Watersheds Monitored by the U.S. Geological Survey Streamflow-gaging Station Network in the Upper Colorado River Basin
}

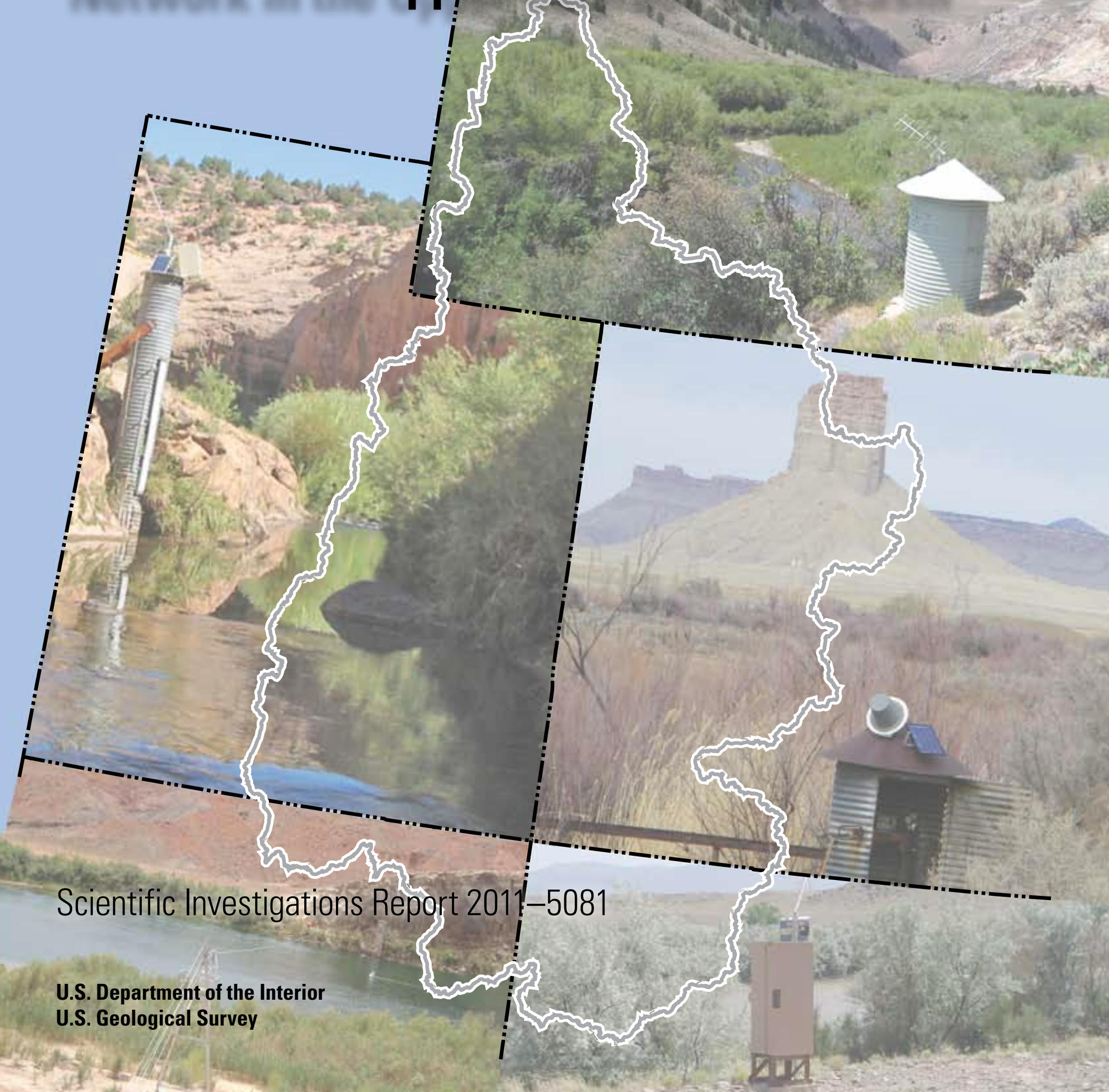


Cover: Photographs of U.S. Geological Survey stream-gaging stations in Wyoming, Colorado, New Mexico, Arizona, and Utah. 


\section{Analysis of Watersheds Monitored by the U.S. Geological Survey Streamflow-gaging Station Network in the Upper Colorado River Basin}

By Terry A. Kenney, Susan G. Buto, and David D. Susong

Scientific Investigations Report 2011-5081 


\title{
U.S. Department of the Interior \\ KEN SALAZAR, Secretary \\ U.S. Geological Survey \\ Marcia K. McNutt, Director
}

\author{
U.S. Geological Survey, Reston, Virginia: 2011
}

For more information on the USGS - the Federal source for science about the Earth, its natural and living resources, natural hazards, and the environment, visit http://www.usgs.gov or call 1-888-ASK-USGS.

For an overview of USGS information products, including maps, imagery, and publications, visit http://www.usgs.gov/pubprod

To order this and other USGS information products, visit http://store.usgs.gov

Any use of trade, product, or firm names is for descriptive purposes only and does not imply endorsement by the U.S. Government.

Although this report is in the public domain, permission must be secured from the individual copyright owners to reproduce any copyrighted materials contained within this report.

Suggested citation:

Kenney, T.A., Buto, S.G., and Susong, D.D., 2011, Analysis of watersheds monitored by the U.S. Geological Survey streamflow-gaging station network in the Upper Colorado River Basin: U.S. Geological Survey Scientific Investigations Report 2011-5081, 47 p. 


\section{Contents}

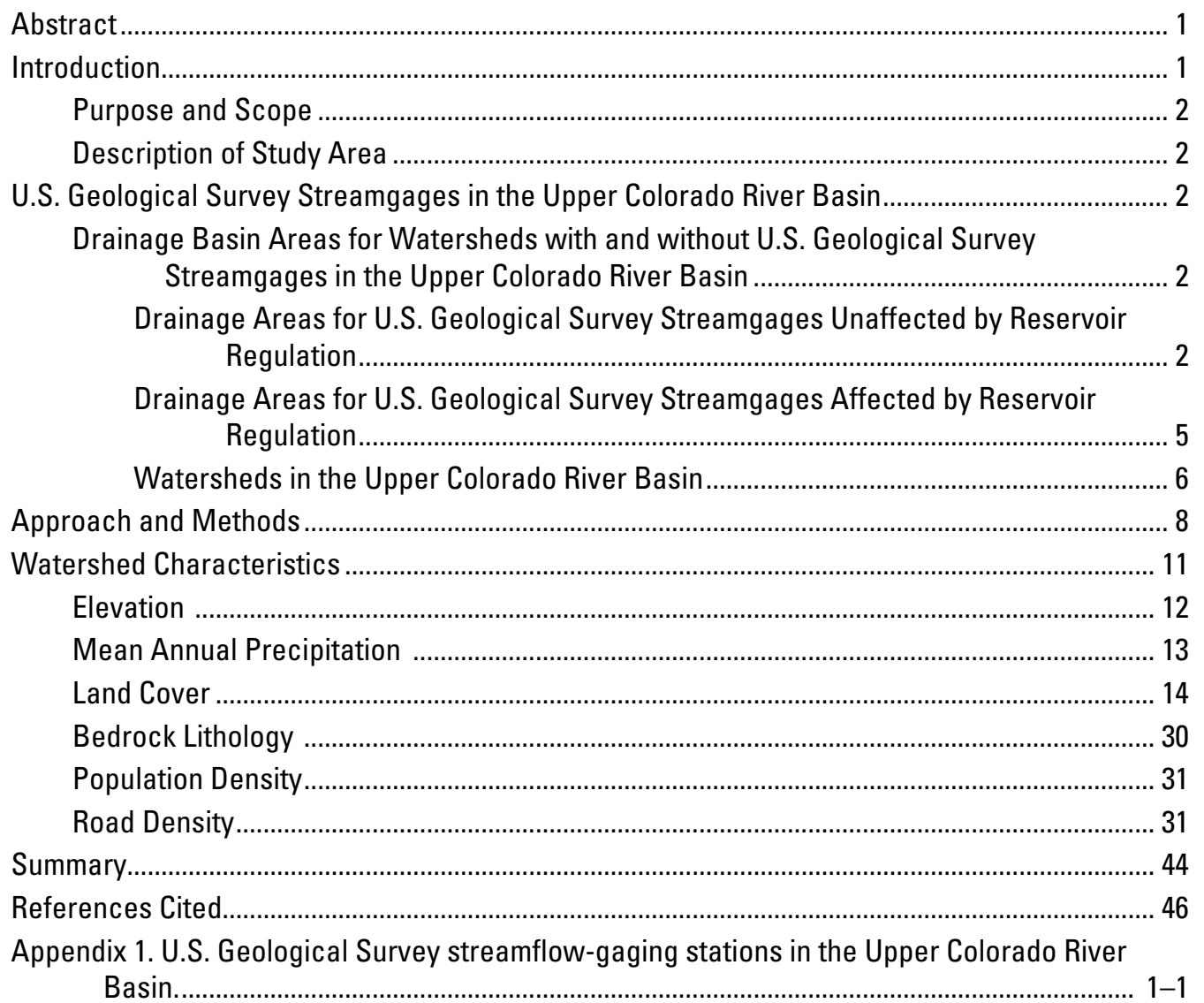

\section{Figures}

1. Map showing upper Colorado River Basin study area .................................................. 3

2. Map showing U.S. Geological Survey streamflow-gaging station network for the Upper Colorado River Basin ......................................................................................... 4

3. Graph showing number of streamgages unaffected by reservoirs (unregulated) with normal capacities of 5,000 acre-feet or more by drainage areas............................. 5

4. Graph showing number of streamgages unaffected by reservoirs (unregulated) with normal capacities of 5,000 acre-feet or more in drainage areas between 0.03 and 400 square miles

5. Graph showing number of streamgages affected by reservoir storage (regulated) of 5,000 acre feet or more by drainage areas .............................................................. 7

6. Graph showing number of streamgages affected by reservoir storage (regulated) of 5,000 acre feet or more in drainage areas between 36.7 and 10,000 square miles ..... 7

7. Diagram showing incremental catchments composing a watershed ................................ 8

8. Graph showing outlets of the watersheds of the Upper Colorado River Basin ............... 9

9. Graph showing number of watersheds in the Upper Colorado River Basin by drainage area 
10. Graph showing number of watersheds in the Upper Colorado River Basin with drainage areas less than 5,000 square miles.

11. Graph showing mean drainage basin elevation for watersheds and U.S. Geological Survey streamgage locations in the Upper Colorado River Basin that are unaffected by reservoir regulation

12. Graph showing mean drainage basin elevation for watersheds and U.S. Geological Survey streamgage locations in the Upper Colorado River Basin that are affected by reservoir regulation

13. Graph showing mean annual precipitation for watersheds and U.S. Geological Survey streamgages in the Upper Colorado River Basin that are unaffected by reservoir regulation

14. Graph showing mean annual precipitation for watersheds and U.S. Geological Survey streamgages in the Upper Colorado River Basin that are affected by reservoir regulation

15. Map showing distribution of seven land cover classifications from the National Land Cover Dataset for the Upper Colorado River Basin

16. Graph showing percentage of drainage area covered by deciduous forest for watersheds and U.S. Geological Survey streamgages in the Upper Colorado River Basin that are unaffected by reservoir regulation

17. Graph showing percentage of drainage area covered by evergreen forest for watersheds and U.S. Geological Survey streamgages in the Upper Colorado River Basin that are unaffected by reservoir regulation

18. Graph showing percentage of drainage area covered by shrubs, young or stunted trees, for watersheds and U.S. Geological Survey streamgages in the Upper Colorado River Basin that are unaffected by reservoir regulation

19. Graph showing percentage of drainage area covered by barren land for watersheds and U.S. Geological Survey streamgages in the Upper Colorado River Basin that are unaffected by reservoir regulation

20. Graph showing percentage of drainage area covered by grass or herbaceous land for watersheds and U.S. Geological Survey streamgages in the Upper

Colorado River Basin that are unaffected by reservoir regulation

21. Graph showing percentage of drainage area covered by mixed forest for watersheds and U.S. Geological Survey streamgages in the Upper Colorado River Basin that are unaffected by reservoir regulation

22. Graph showing percentage of drainage area covered by developed land for watersheds and U.S. Geological Survey streamgages in the Upper Colorado River Basin that are unaffected by reservoir regulation

23. Graph showing percentage of drainage area covered by deciduous forest for watersheds and U.S. Geological Survey streamgages in the Upper Colorado River Basin that are affected by reservoir regulation.

24. Graph showing percentage of drainage area covered by evergreen forest for watersheds and U.S. Geological Survey streamgages in the Upper Colorado River Basin that are affected by reservoir regulation

25. Graph showing percentage of drainage area covered by shrubs, young or stunted trees for watersheds and U.S. Geological Survey streamgages in the Upper Colorado River Basin that are affected by reservoir regulation

26. Graph showing percentage of drainage area covered by barren land for watersheds and U.S. Geological Survey streamgages in the Upper Colorado River Basin that are affected by reservoir regulation. 
27. Graph showing percentage of drainage area covered by grass or herbaceous land for watersheds and U.S. Geological Survey streamgages in the Upper

Colorado River Basin that are affected by reservoir regulation

28. Graph showing percentage of drainage area covered by mixed forest for watersheds and U.S. Geological Survey streamgages in the Upper Colorado River Basin that are affected by reservoir regulation

29. Graph showing percentage of drainage area covered by developed land for watersheds and U.S. Geological Survey streamgages in the Upper Colorado River Basin that are affected by reservoir regulation

30. Map showing the distribution of the six lithologic classifications in the Upper Colorado River Basin

31. Graph showing percentage of drainage basin area having sedimentary, clastic lithology (Mesozoic) for watersheds and U.S. Geological Survey streamgages in the Upper Colorado River Basin that are unaffected by reservoir regulation

32. Graph showing percentage of drainage basin area having sedimentary, clastic (continental) lithology (Tertiary) for watersheds and U.S. Geological Survey streamgages in the Upper Colorado River Basin that are unaffected by reservoir regulation

33. Graph showing percentage of area having igneous or metamorphic lithologies for watersheds and U.S. Geological Survey streamgages in the Upper Colorado River Basin that are unaffected by reservoir regulation

34. Graph showing percentage of drainage basin area having sedimentary, mixed (continental and marine) lithology for watersheds and U.S. Geological Survey streamgages in the Upper Colorado River Basin that are affected by reservoir regulation

35. Graph showing percentage of drainage basin area having sedimentary, carbonate (marine) lithology for watersheds and U.S. Geological Survey streamgages in the Upper Colorado River Basin that are unaffected by reservoir regulation

36. Graph showing percentage of drainage basin area having sedimentary, clastic lithology (Mesozoic) for watersheds and U.S. Geological Survey streamgages in the Upper Colorado River Basin that are affected by reservoir regulation .

37. Graph showing percentage of drainage basin area having sedimentary, clastic (continental) lithology (Tertiary) for watersheds and U.S. Geological Survey streamgages in the Upper Colorado River Basin that are affected by reservoir regulation

38. Graph showing percentage of drainage basin area having igneous or metamorphic lithology for watersheds and U.S. Geological Survey streamgages in the Upper Colorado River Basin that are affected by reservoir regulation

39. Graph showing percentage of drainage basin area having sedimentary, mixed (continental and marine) lithology for watersheds and U.S. Geological Survey streamgages in the Upper Colorado River Basin that are affected by reservoir regulation

40. Graph showing percentage of drainage basin area having sedimentary, carbonate (marine) lithology for watersheds and U.S. Geological Survey streamgages in the Upper Colorado River Basin that are affected by reservoir regulation

41. Graph showing population density for watersheds and U.S. Geological Survey streamgage locations in the Upper Colorado River Basin that are unaffected by reservoir regulation 
42. Graph showing population density for watersheds and U.S. Geological Survey streamgage locations in the Upper Colorado River Basin that are affected by reservoir regulation

43. Graph showing road density for watersheds and U.S. Geological Survey streamgage locations in the Upper Colorado River Basin that are unaffected by reservoir regulation

44. Graph showing road density for watersheds and U.S. Geological Survey streamgage locations in the Upper Colorado River Basin that are affected by reservoir regulation

\section{Tables}

1. Number of unregulated and regulated U.S. Geological Survey streamflow-gaging stations and Upper Colorado River Basin watersheds examined ..................................... 5

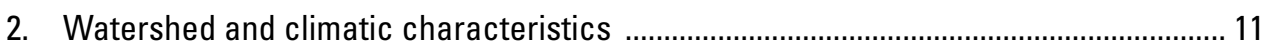

3. Description of land cover classifications from the National Land Cover Dataset ......... 15

4. Six lithologic classifications in the Upper Colorado River Basin (Kenney and others, 2009)

Appendix

A-1. Watershed characteristics for the U.S. Geological Survey streamgage network in the Upper Colorado River Basin

\section{Conversion Factors}

Inch/Pound to SI

\begin{tabular}{|c|c|c|}
\hline Multiply & By & To obtain \\
\hline \multicolumn{3}{|c|}{ Length } \\
\hline inch (in.) & 2.54 & centimeter $(\mathrm{cm})$ \\
\hline foot $(\mathrm{ft})$ & 0.3048 & $\operatorname{meter}(\mathrm{m})$ \\
\hline mile (mi) & 1.609 & kilometer $(\mathrm{km})$ \\
\hline \multicolumn{3}{|c|}{ Area } \\
\hline square mile $\left(\mathrm{mi}^{2}\right)$ & 2.590 & square kilometer $\left(\mathrm{km}^{2}\right)$ \\
\hline \multicolumn{3}{|c|}{ Volume } \\
\hline acre-foot (acre ft) & 1,233 & cubic meter $\left(\mathrm{m}^{3}\right)$ \\
\hline
\end{tabular}

Vertical coordinate information is referenced to the North American Vertical Datum of 1988 (NAVD 88).

Horizontal coordinate information is referenced to the North American Datum of 1983 (NAD 83). 


\title{
Analysis of Watersheds Monitored by the U.S. Geological Survey Streamflow-gaging Station Network in the Upper Colorado River Basin
}

\author{
By Terry A. Kenney, Susan G. Buto, and David D. Susong
}

\section{Abstract}

The U.S. Geological Survey (USGS) has operated streamflow-gaging stations in 1,053 watersheds in the Upper Colorado River Basin (UCRB) since 1894. Currently, 223 of these streamgages are active. This report presents selected watershed characteristics for 10,338 watersheds in the UCRB. These watersheds are compared to the watersheds upstream of USGS streamgages to assess how well the USGS streamgage network represents the physical characteristics of the watersheds in the entire basin. To conduct this assessment, 17 watershed characteristics, including physiographic parameters, land cover types, lithology, and parameters that describe anthropogenic influence, were computed for each of the gaging station drainage basins. The set of 10,338 watersheds in the UCRB was constructed from a previously developed stream-reach network, and the same 17 basin characteristics were computed for each watershed to facilitate comparisons.

The USGS streamgage watersheds and the UCRB watersheds were split into those that are currently unaffected by upstream reservoir regulation and those currently affected by upstream reservoir regulation. In general, for unregulated watersheds, the streamgage network represents the range of most basin characteristics in the watersheds of the UCRB. However, the active streamgage network for unregulated watersheds is generally lacking in representation of most basin characteristics compared with watersheds in the UCRB. At regulated locations, the streamgage network including the active network, generally represents the range of most basin characteristics well.

\section{Introduction}

The U.S. Geological Survey (USGS) began gaging streamflow in the Upper Colorado River Basin (UCRB) with the installation of the Green River at Green River, Utah, streamgage in 1894. Since that time, the USGS has operated streamgages at more than 1,050 sites in the UCRB. The purposes for these gaging stations vary and have changed with the needs for differing water information over the last century.

In the late 19th and early 20th centuries, gaging stations in the UCRB were established to quantify the amount of water in the basin as a result of the Sundry Civil Appropriations Act of 1888. The act mandated that the USGS, under the direction of the Secretary of the Interior, investigate the extent to which the arid region of the United States could be redeemed by irrigation and for selecting sites for reservoirs and other hydraulic works (Corbett and others, 1943). Following the signing of the Colorado Compact in 1922, gaging stations were established to assist the Upper Basin States of Colorado, Utah, Wyoming, New Mexico, and Arizona, with accounting for their allocation of Colorado River water. As water development projects, specifically reservoirs, were conceived, streamgages were established to aid in both assessing the utility of sites and ultimately, in the design of the structures. As the population of the region grew both within and bordering the UCRB, for example, in the Colorado Front Range, the need to develop municipal water supplies expanded the USGS streamgage network in the UCRB. The number of gaging stations also increased to assist in managing and distributing water, specifically for agricultural use and water rights management. Infrastructure improvements, such as highways and roads, in the middle of the 20th century also led to the establishment of streamgages to provide data for the design and construction of bridges. Streamflow data in the latter part of the 20th century and into the 21 st century are used for understanding the relation between streamflow and water quality, streamflow and climate, and streamflow and ecology. Over time there has been an evolution in water resource issues, and the USGS streamgage network has evolved and changed with the issues. With the changing needs for streamflow data, existing gages are discontinued, new gages are established, and older gages, in some cases, are reactivated. In addition to the scientific and engineering needs for streamgages, socioeconomic factors have influenced the growth and decline of the USGS streamgage network in the UCRB. 


\section{Purpose and Scope}

The purpose of this report is to present the results of an examination of the USGS streamgage network, both past and present, in the UCRB in terms of the physical watershed characteristics of the UCRB. The watersheds monitored by the current network of active streamgages and watersheds previously monitored by inactive USGS streamgages are compared with watersheds in the UCRB in terms of drainage basin size and selected watershed characteristics. The UCRB is subdivided into a set of 10,338 watersheds, which are compared to the subset of watersheds instrumented with USGS streamgages. The objective of this comparison is to assess how well the watersheds instrumented with USGS streamgages represent the varied landscapes in all UCRB watersheds.

\section{Description of Study Area}

The Colorado River Basin, which drains portions of seven states, is the largest river basin in the southwestern United States. The UCRB, for purposes of this assessment, is defined as the drainage basin upstream of USGS streamflow-gaging station 09380000, Colorado River at Lees Ferry, Arizona. The UCRB has a contributing drainage area of about $108,000 \mathrm{mi}^{2}$ and includes parts of Wyoming, Colorado, Utah, New Mexico, and Arizona (fig. 1). The UCRB drains a large portion of the Rocky Mountains west of the Continental Divide, from the Wind River Mountains in Wyoming south to the San Juan Mountains in Colorado. Major drainages in the UCRB include those of the Colorado, Green, and San Juan Rivers.

\section{U.S. Geological Survey Streamgages in the Upper Colorado River Basin}

The earliest computed daily mean discharge value in the UCRB is for October 1, 1894, from USGS streamflow-gaging station 09315000, Green River at Green River, Utah. As of 2010, there were 1,067 USGS streamgages in the UCRB, with at least 365 daily mean discharge values contained in the USGS National Water Information System (NWIS) database (fig. 2; table 1; Appendix A). This compilation of streamgages includes both active and inactive gages, as well as 14 inactive gages whose locations are currently inundated by reservoirs. Active gages are those in operation by the USGS in 2010. Inactive gages are gages that have been historically operated by the USGS and have a minimum of 365 days of daily mean discharge values. These inactive gages have varying periods of record (Appendix A). Of the 1,053 streamgages in the UCRB, 223 were active in 2010 (U.S. Geological Survey National Water Information System; http://nwis.waterdata. usgs.gov). Thus, for the purposes of this report, the USGS streamgage network is referenced in three ways: the entire USGS streamgage network, which includes 1,053 inactive and active gages; the inactive USGS streamgage network, which includes 830 inactive gages; and the active USGS streamgage network, which includes the 223 gages in operation in 2010. Streamgages located on unnatural watercourses, such as canals, are not included in this analysis.

There are 80 water-storage reservoirs greater than 5,000 acre-ft in the UCRB (Ruddy and Hitt, 1990). Agricultural activities and the human population in the UCRB are dependent upon these reservoirs. Water storage in these reservoirs substantially alters the natural streamflow patterns of the streams they impound as well as those downstream. Of the 1,053 streamgages in the UCRB, 226 gages are located downstream of reservoirs with capacities of at least 5,000 acre- $\mathrm{ft}$ (Ruddy and Hitt, 1990). To distinguish between regulated and unregulated streamflow in this investigation, streamgages and watersheds in the UCRB were divided into two groups: 1) unregulated, which are gages and watersheds that are unaffected by upstream reservoir regulation, and 2) regulated, which are gages and watersheds that were affected by reservoir regulation as of 1990 (Ruddy and Hitt, 1990). Reservoir regulation, as defined for this study, pertains to gages that are located downstream of at least 5,000 acre- $\mathrm{ft}$ of reservoir capacity. Other human influenced water development, such as diversion canals and transbasin diversions, was not considered in the regulated/unregulated classification of watersheds. Because of the availability of data on reservoirs in the UCRB and because, in general, unless the watershed is very small, a reservoir smaller than 5,000 acre-ft does not have much affect on downstream streamflow, 5,000 acre-ft was selected as the minimum amount of reservoir capacity to be considered a regulated watershed in this report.

\section{Drainage Basin Areas for Watersheds with and without U.S. Geological Survey Streamgages in the Upper Colorado River Basin}

Drainage basin area is a fundamental landscape characteristic that is used when classifying or studying streams and streamflow. In this study, drainage area is used as the firstorder watershed descriptor by which other landscape characteristics are presented. All USGS streamgage locations have the contributing drainage area computed; drainage areas for the set of UCRB watersheds were also computed.

\section{Drainage Areas for U.S. Geological Survey Streamgages Unaffected by Reservoir Regulation}

Drainage areas for the 827 unregulated streamgage locations in the UCRB range from 0.03 to $4,040 \mathrm{mi}^{2}$. In 2010, 125 of these gages were active. Drainage areas for active gage locations range from 2.27 to $4,040 \mathrm{mi}^{2}$. The number of unregulated streamgages by drainage area, grouped in $200 \mathrm{mi}^{2}$ increments, is shown in figure 3 . There are 112 currently active 


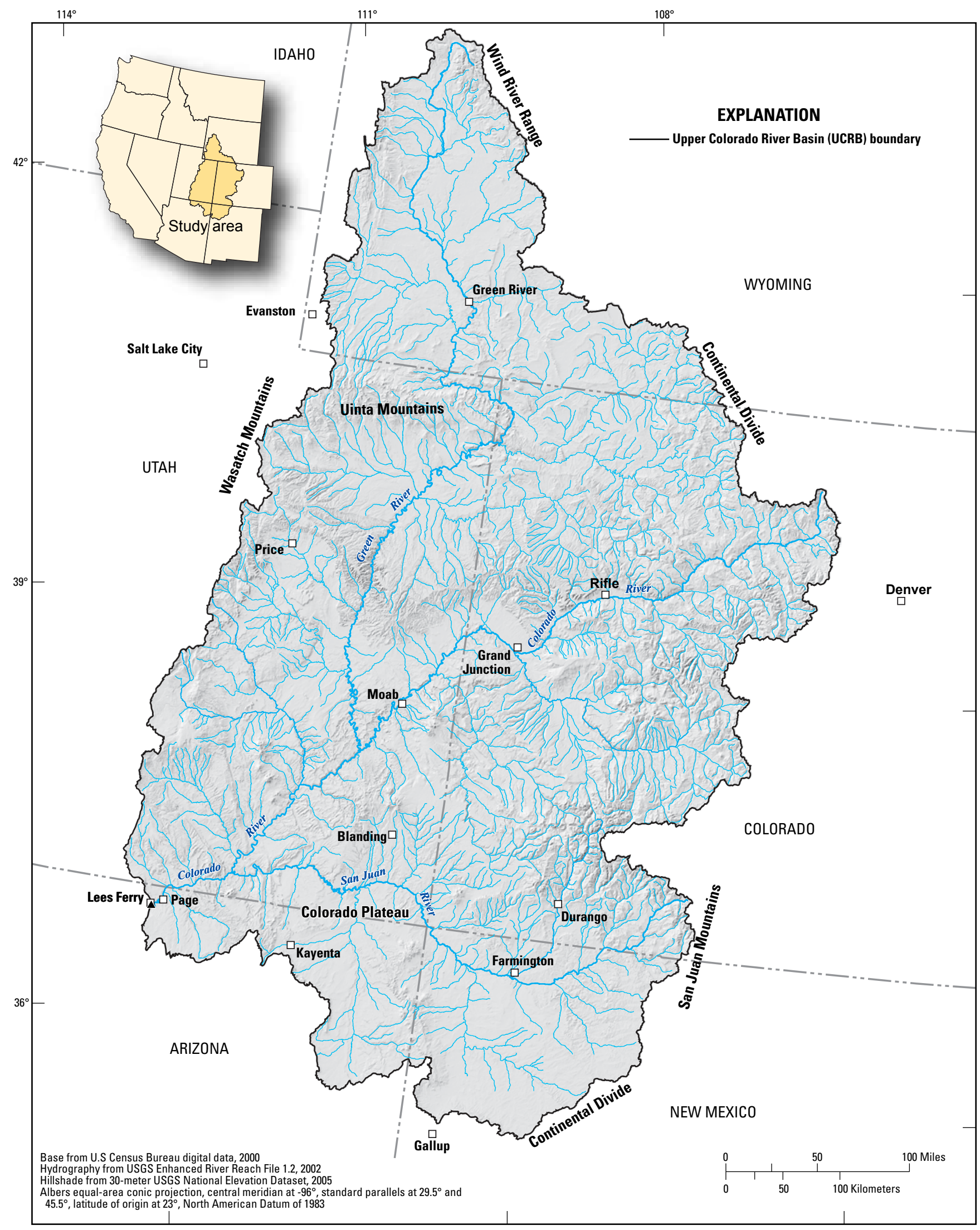

Figure 1. Upper Colorado River Basin study area. 


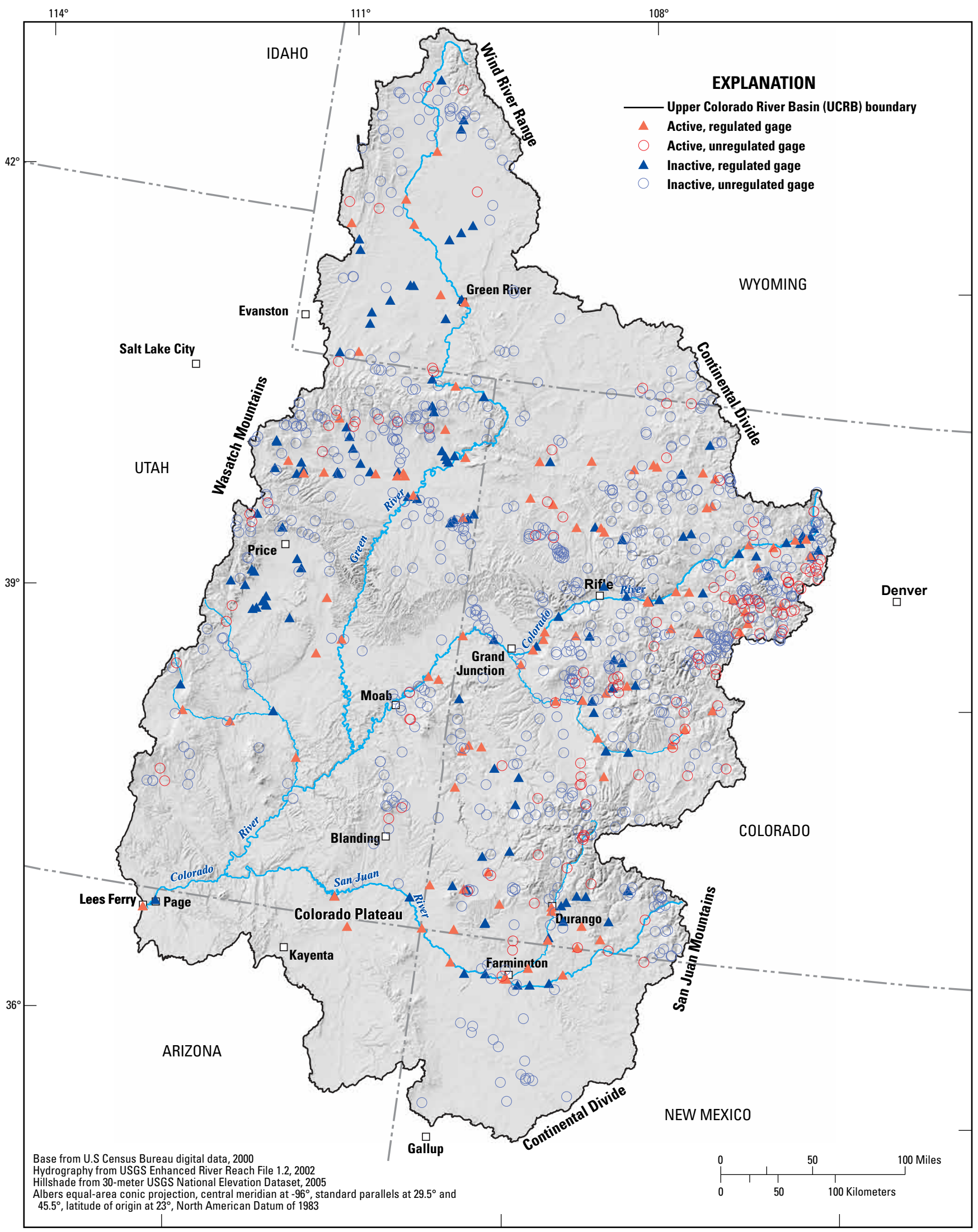

Figure 2. U.S. Geological Survey streamflow-gaging station network for the Upper Colorado River Basin. 
Table 1. Number of unregulated and regulated U.S. Geological Survey streamflow-gaging stations and Upper Colorado River Basin watersheds examined.

\begin{tabular}{lcccr}
\hline \multicolumn{1}{c}{ Site } & Total number & $\begin{array}{c}\text { Number where out- } \\
\text { let is not inundated } \\
\text { by reservoir }\end{array}$ & $\begin{array}{c}\text { Number that are } \\
\text { unregulated }\end{array}$ & $\begin{array}{c}\text { Number that are } \\
\text { regulated }\end{array}$ \\
\hline U.S. Geological Survey streamgages & 1,067 & 1,053 & 827 & 226 \\
$\quad$ Active & 223 & 223 & 112 & 98 \\
$\quad$ Inactive & 844 & 830 & 715 & 128 \\
& & & & 1,353 \\
\hline Upper Colorado River Basin watersheds & 10,679 & 10,338 & 8,985 & \\
\hline
\end{tabular}

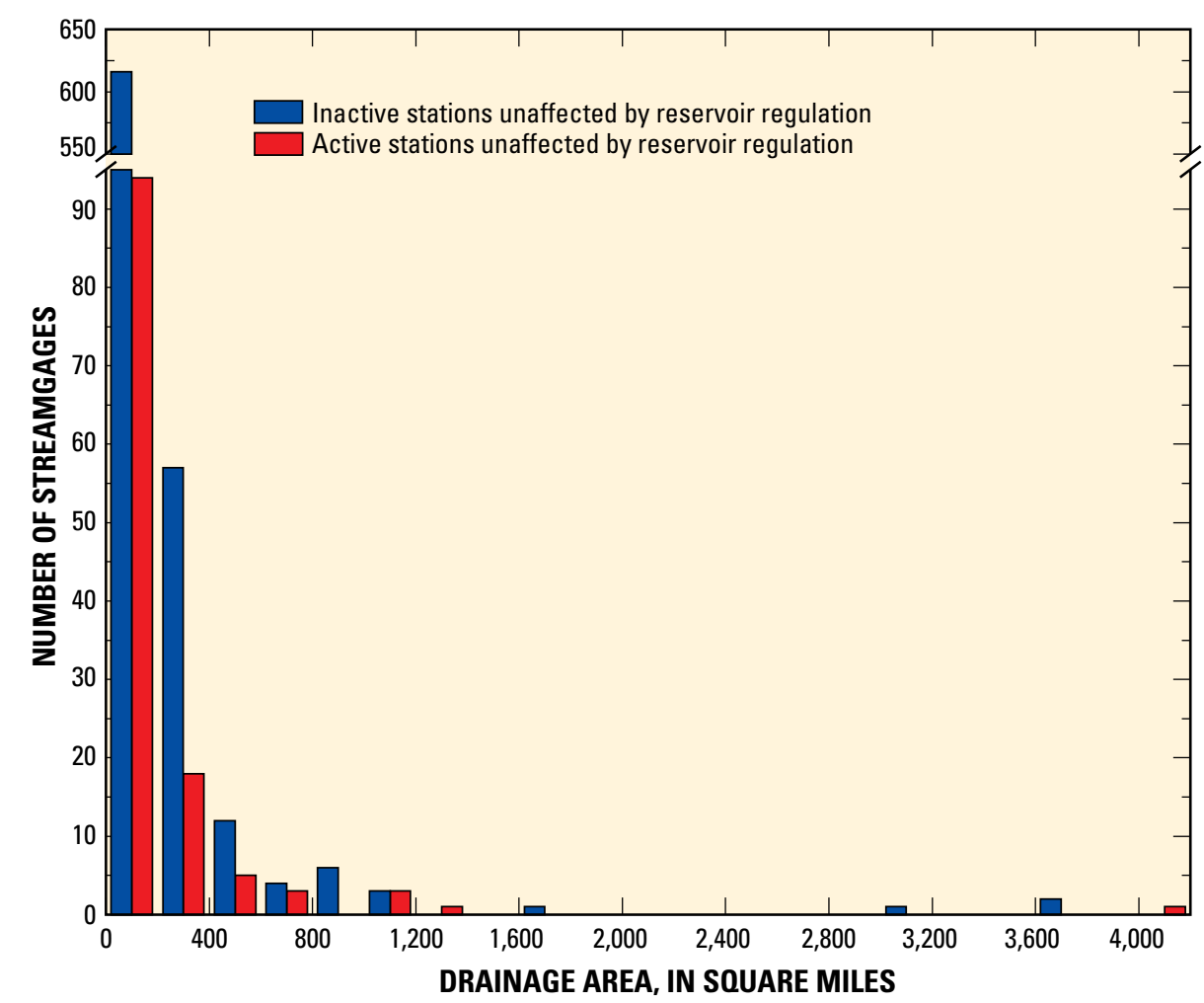

Figure 3. Number of streamgages unaffected by reservoirs (unregulated) with normal capacities of 5,000 acre-feet or more by drainage areas.

stations out of 785 stations that have drainage areas ranging from 0.03 to $400 \mathrm{mi}^{2}$. The average period of record for the 785 gages is 17 years, whereas the average period of record for the 112 active gages is 42 years. The number of streamgages having drainage areas from 0.03 to $400 \mathrm{mi}^{2}$, grouped in $25 \mathrm{mi}^{2}$ increments, is shown in figure 4 . There are only 25 currently active streamgages out of 332 that have drainage areas less than $25 \mathrm{mi}^{2}$ in the UCRB. The 332 streamgage locations having drainage areas less than $25 \mathrm{mi}^{2}$ have an average period of record of about 13 years, whereas the 25 active stations have an average period of record of about 32 years. Finally, there are 88 gages, 4 of which are active, in drainage areas less than $5 \mathrm{mi}^{2}$.

\section{Drainage Areas for U.S. Geological Survey Streamgages Affected by Reservoir Regulation}

Of the 1,053 USGS streamgages in the UCRB, 226 are downstream of water-storage reservoirs with a normal capacity of at least 5,000 acre $\mathrm{ft}$ (Ruddy and Hitt, 1990). The period of record for many of these gages begins prior to any upstream water development. Thus, data from these gages potentially represent a mix of unregulated and regulated streamflow conditions, but for the purposes of this investigation, all of these 226 streamgages are considered affected by reservoir regulation. Drainage areas for the gages affected by upstream reservoir regulation range from 8.2 to $108,000 \mathrm{mi}^{2}$. Of the 226 gages affected by regulation, 98 active gages have 


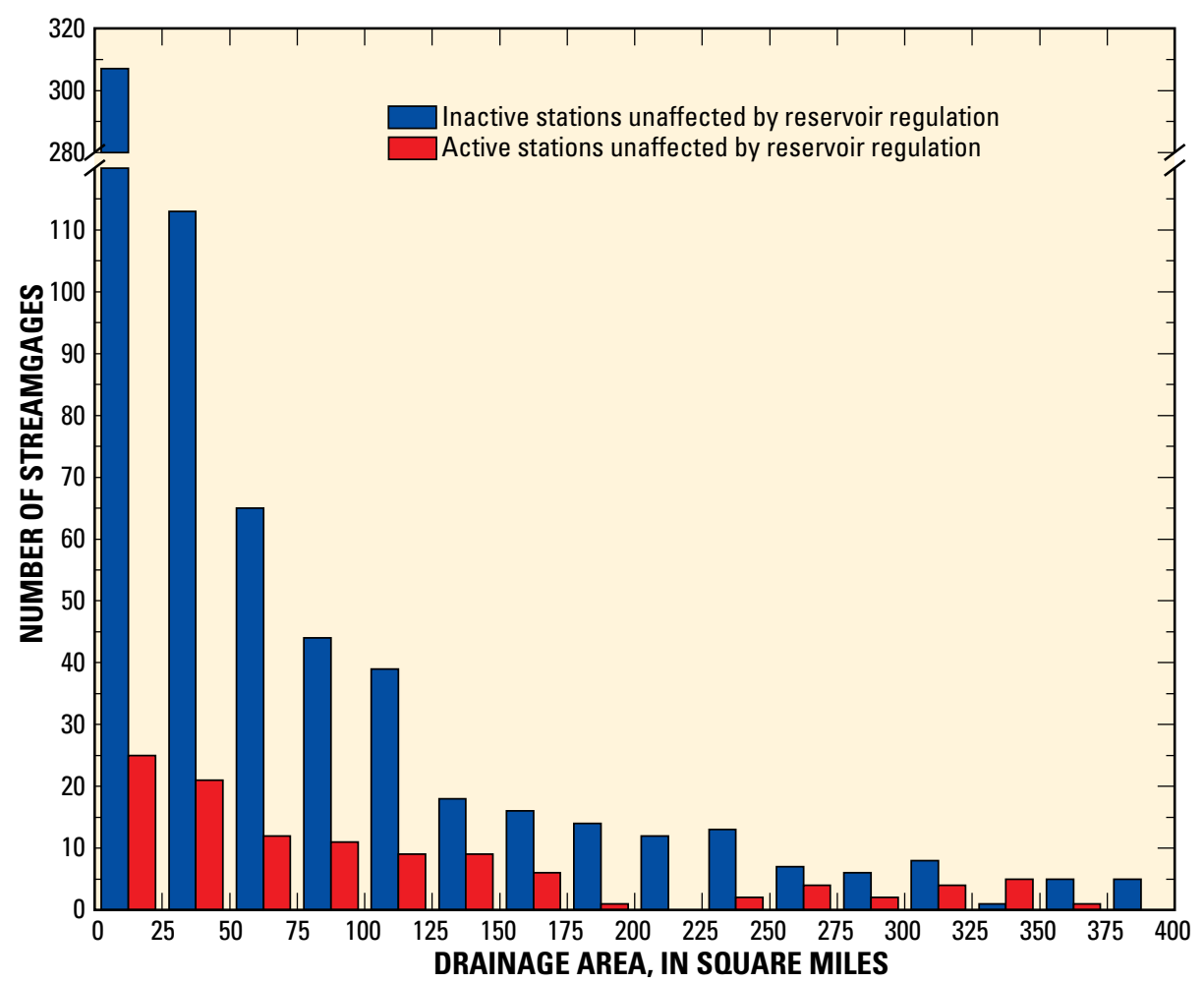

Figure 4. Number of streamgages unaffected by reservoirs (unregulated) with normal capacities of 5,000 acre-feet or more in drainage areas between 0.03 and 400 square miles.

drainage areas ranging from 36.7 to $108,000 \mathrm{mi}^{2}$. The number of regulated streamgages by drainage area, grouped in 5,000 $\mathrm{mi}^{2}$ increments, is shown in figure 5 . A total of 15 gages, 10 of which are active, have drainage areas greater than $10,000 \mathrm{mi}^{2}$. Only two gages, one of which is active, have drainage areas greater than $50,000 \mathrm{mi}^{2}$. The number of regulated streamgages with drainage areas less than $10,000 \mathrm{mi}^{2}$, grouped in $1,000 \mathrm{mi}^{2}$ increments, is shown in figure 6.

\section{Watersheds in the Upper Colorado River Basin}

To assess the representation of the watersheds in the UCRB by the USGS streamgage network, the watersheds with streamgages need to be compared with a dataset that represents all of the watersheds within the UCRB. For this assessment, a dataset of the watersheds in the UCRB was created from a synthetic stream-reach network consisting of 10,679 incremental catchments that were developed for a dissolvedsolids surface-water quality model of the UCRB (Kenney and others, 2009). The stream-reach network consists of stream reaches and associated incremental catchments. These incremental catchments are bound upstream and downstream by other catchments and, therefore, do not represent entire watersheds unless they are the upstream-most, or headwater, catchment (fig. 7). The drainage areas of the incremental catchments of the synthetic stream-reach network ranged in size from $0.5 \mathrm{mi}^{2}$ to $78 \mathrm{mi}^{2}$, with an average area of about 10 $\mathrm{mi}^{2}$ (Kenney and others, 2009). This network of unique stream reaches is linked by to- and from- nodes and a hydrologic sequence number that allows for downstream accumulation of constituent mass (used in the water-quality model) or, for the benefit of this analysis, provides a means to sum the upstream watershed characteristics of the incremental catchments to create a dataset of watersheds. By taking advantage of the linkages and sequencing of this network, a set of 10,679 watersheds of the UCRB was created for this assessment (fig. 8), and the areas of each of these watersheds were computed. The drainage areas of the resulting watershed dataset range in size from $0.5 \mathrm{mi}$ to $108,000 \mathrm{mi}^{2}$. As would be expected, all of the watersheds are nested in watersheds that are located in the downstream direction.

Once the UCRB watershed dataset was constructed, it was compared to locations of reservoirs in the UCRB. Using the 24,000-scale National Hydrography Dataset (NHD 24k; U.S. Geological Survey, 1999), 341 of the 10,679 watersheds were found to have the outlet location inundated by one of the many reservoirs in the UCRB. These watersheds were removed from the analysis, leaving 10,338 watersheds to compare with the 1,053 watersheds represented by the USGS streamgage network in the UCRB. The practical lower limit of drainage basin area for the UCRB watershed dataset is about $5 \mathrm{mi}^{2}$. This is a function of the reach network and catchments that were used to generate the UCRB watershed dataset. Therefore, most comparisons of the UCRB streamgage net- 


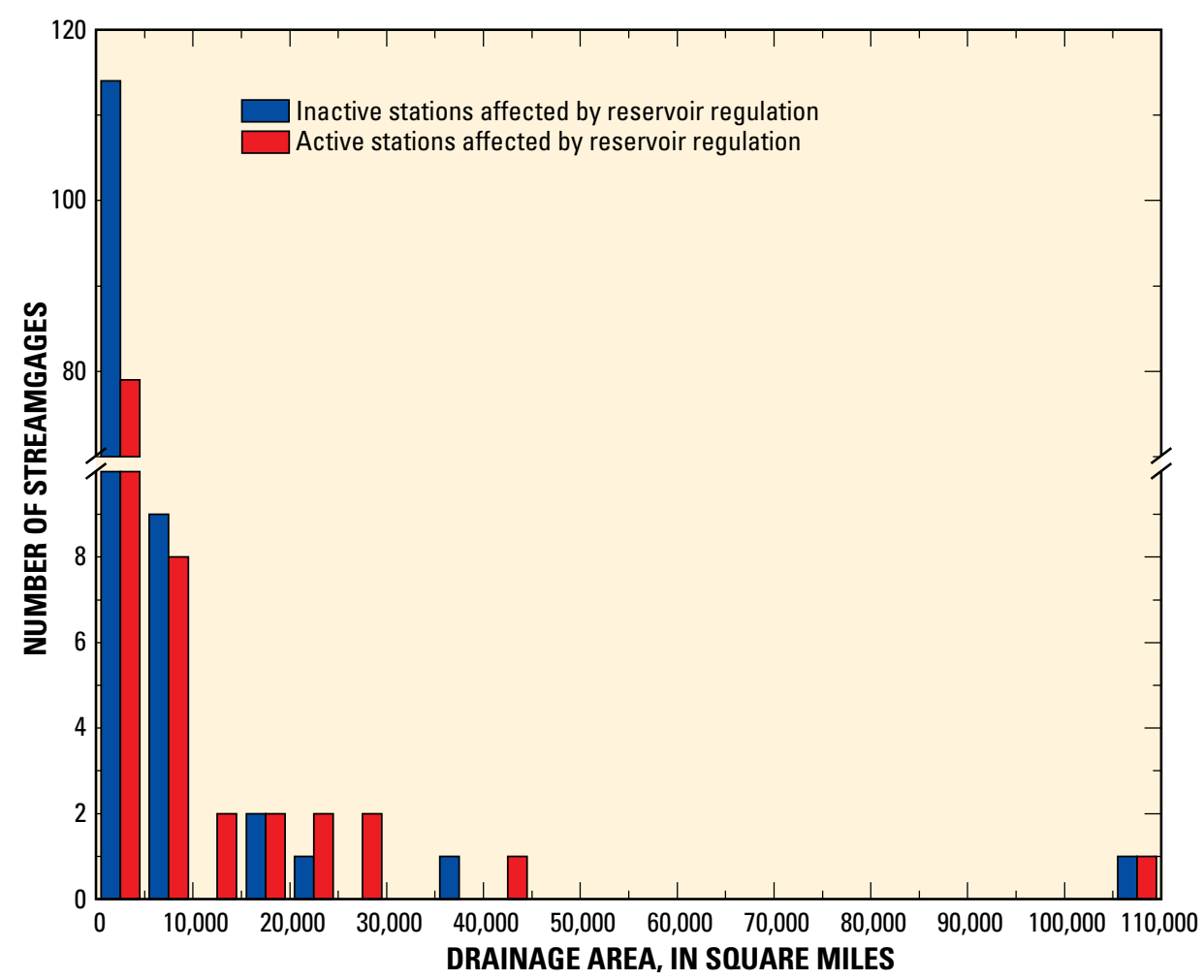

Figure 5. Number of streamgages affected by reservoir storage (regulated) of 5,000 acre feet or more by drainage areas.

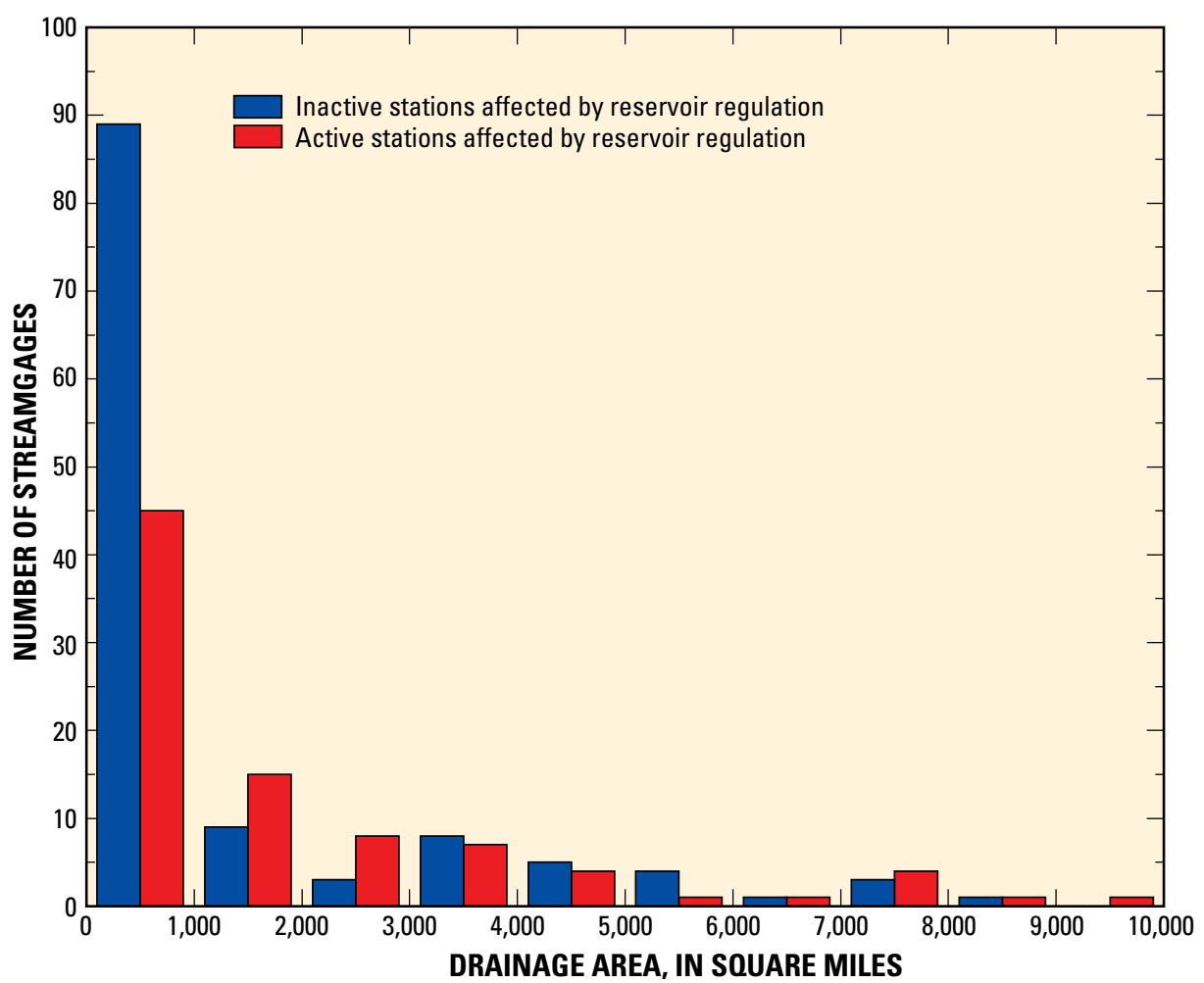

Figure 6. Number of streamgages affected by reservoir storage (regulated) of 5,000 acre feet or more in drainage areas between 36.7 and 10,000 square miles. 


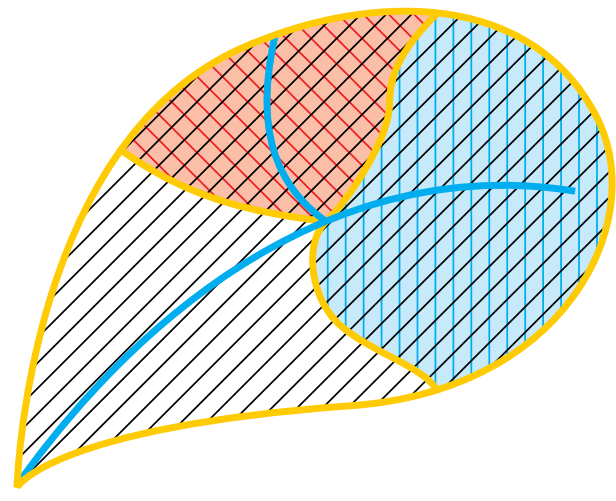

Incremental watershed 1

Incremental watershed 2

Incremental watershed 3

Watershed 1

Watershed 2

Watershed 3

Stream

Watershed boundary
Figure 7. Diagram showing incremental catchments composing a watershed.

work with the watershed dataset will focus on basins greater than $5 \mathrm{mi}^{2}$. The number of unregulated and regulated watersheds in the UCRB by drainage area, grouped in $5,000 \mathrm{mi}^{2}$ increments, is shown in figure 9. All unregulated watersheds in the UCRB have drainage areas that are less than 5,000 $\mathrm{mi}^{2}$, which is similar to the largest drainage area for an unregulated USGS streamgage of $4,040 \mathrm{mi}^{2}$. About 900 regulated UCRB watersheds have drainage areas that are less than 5,000 $\mathrm{mi}^{2}$. The number of watersheds by drainage area that are less than $5,000 \mathrm{mi}^{2}$, grouped in $250 \mathrm{mi}^{2}$ increments, is shown in figure 10 .

\section{Approach and Methods}

Characteristics of watersheds instrumented with USGS streamgages are compared with characteristics of watersheds in the UCRB watershed dataset to assess how well the USGS streamgage network represents the varied landscapes in the UCRB. These comparisons are presented graphically in scatter plots with corresponding bar graphs for each watershed characteristic for both regulated and unregulated watersheds. The scatter plots are constructed with drainage area on the y-axis and the watershed characteristic, such as mean basin elevation or percent evergreen forest cover, on the x-axis. Computed characteristic values for watersheds with active USGS gages are represented by solid red circles, and computed values for watersheds with inactive USGS gages are represented by solid blue circles. Computed characteristic values for the UCRB watersheds that do not have USGS streamgages are shown as light gray circles.

This graphical presentation provides a visual representation of how well the USGS streamgage network, both current and historical, captures the varied landscapes of the watersheds in the UCRB. Gaps and (or) bias in representation of specific watershed characteristics and drainage areas by the USGS streamgage network can be easily identified using the graphs. For example, if the characteristic values for watersheds instrumented with USGS gages are evenly distributed across the range of values and drainage areas for all watersheds in the UCRB, this indicates that watersheds instrumented with USGS streamgages are representative of the watershed characteristic. Conversely, if there are gaps or the watersheds with USGS gages are biased for a watershed characteristic, it indicates that the USGS streamgage network is not repesenting the full range of watersheds in the UCRB for that watershed characteristic.

To provide a more quantitative measure of how well the USGS streamgage network represents the watersheds in the UCRB, the ratio of the number of USGS streamgages to the number of watersheds for each watershed characteristic was computed at various intervals along the range of each watershed characteristic. This ratio is presented as a percentage and is represented with bar graphs at the top of the scatter plots. The bar graphs share the same $\mathrm{x}$-axis as the scatter plots and the bars correspond to intervals of the watershed characteristic being examined. The green bar is the percentage of UCRB watersheds instrumented with USGS gages (entire USGS network) that share the same range of values of a specific watershed characteristic. The red bar is the percentage of UCRB watersheds having active USGS gages that share the same range of values of a specific watershed characteristic. Drainage areas below $5 \mathrm{mi}^{2}$ were not included in the calculations for the bar graphs. The watershed characteristic values shown for a gaging station (red and blue dots) may not exactly correspond to, or overlap, the watershed characteristic for a watershed in the UCRB because streamgages may not be located in the exact location on the stream as the watershed outlet. Because of this, the bar graphs, particularly where the number of UCRB watersheds is small, may indicate a larger representation of the watershed characteristic by the gage network.

Scatter plots and bar graphs for each watershed characteristic were developed for both regulated and unregulated watersheds and are discussed in following sections of the report. The discussion for each of the watershed characteristics is limited to brief general statements about how well the USGS streamgage network represents watershed characteristics in the UCRB as shown by the scatter plots and bar graphs.

To assess how well the USGS streamgage network represents a specific watershed characteristic, a comparison of the number of watersheds with USGS streamgages to the total number of watersheds that share the same values of a specific watershed characteristic is used. By treating each of the watersheds in the UCRB as an independent watershed with the potential for locating a streamgage, it can be determined that the entire USGS streamgage network measures streamflow in about 9.2 percent of the unregulated watersheds in the UCRB ( 827 gages and 8,985 watersheds). The active USGS streamgage network measures streamflow in about 1.4 percent of the unregulated watersheds in the UCRB (125 gages and 8,985 watersheds). For a specific watershed characteristic, if the ratio, presented as a percentage, of unregulated USGS 


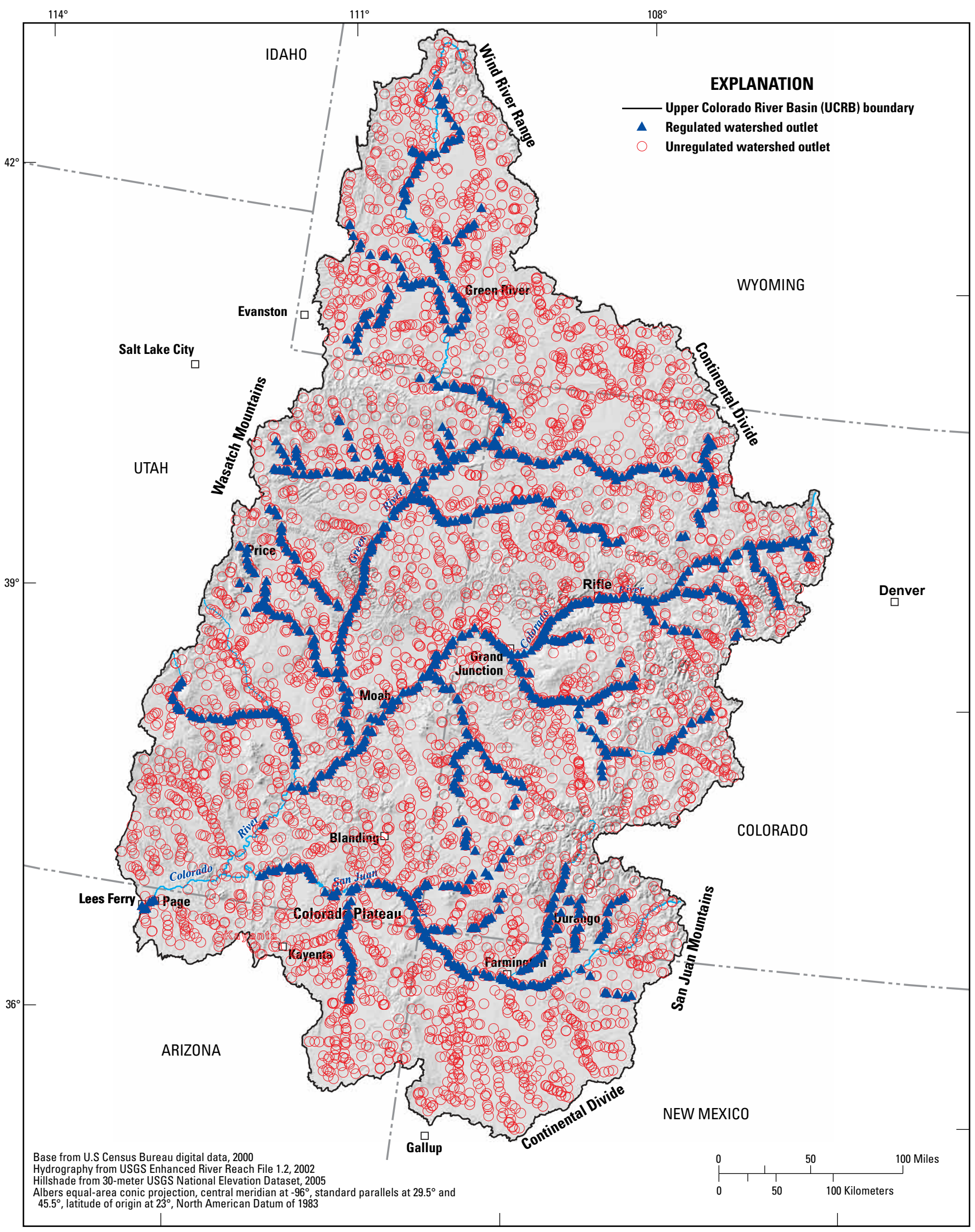

Figure 8. Outlets of the watersheds of the Upper Colorado River Basin. 


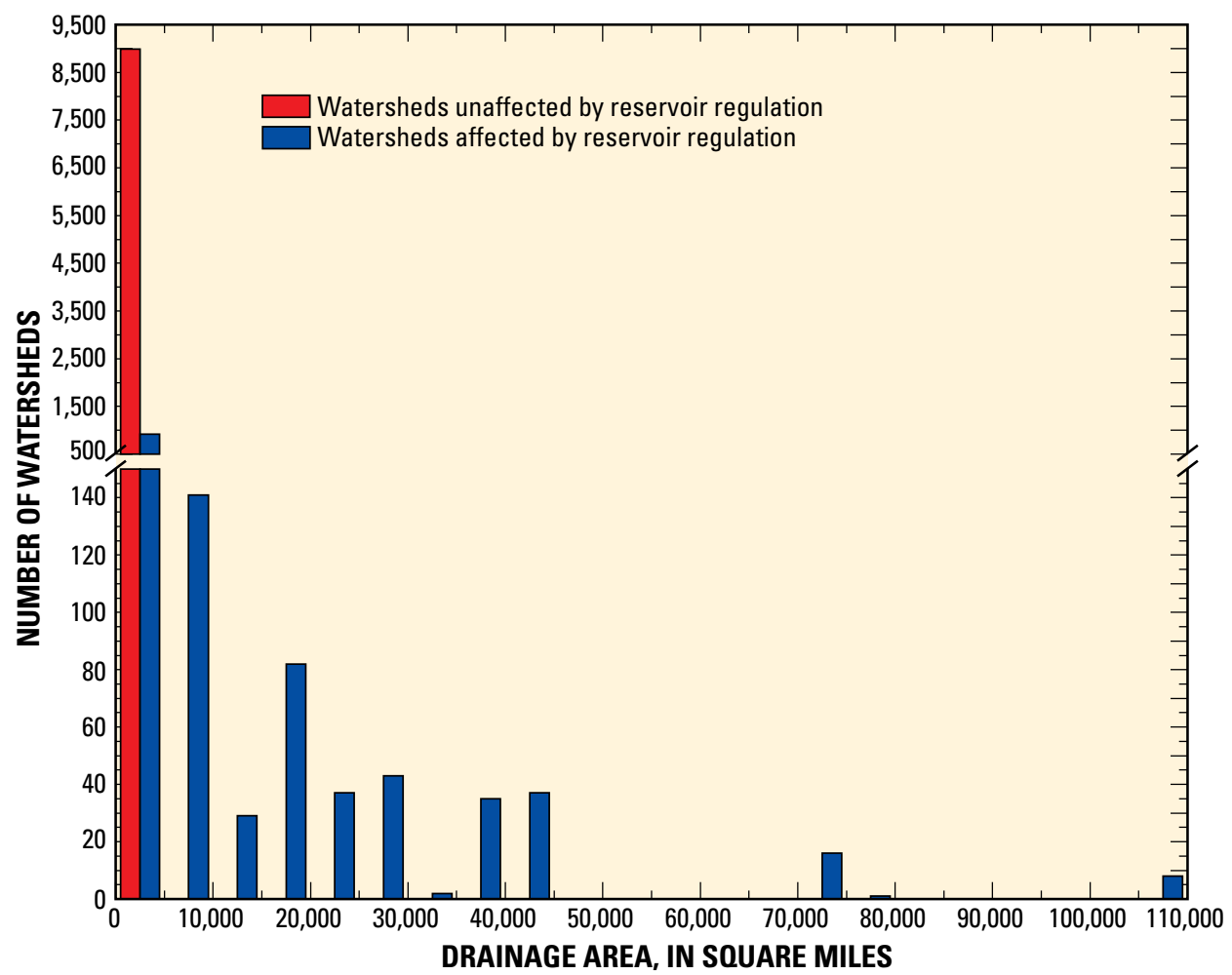

Figure 9. Number of watersheds in the Upper Colorado River Basin by drainage area.

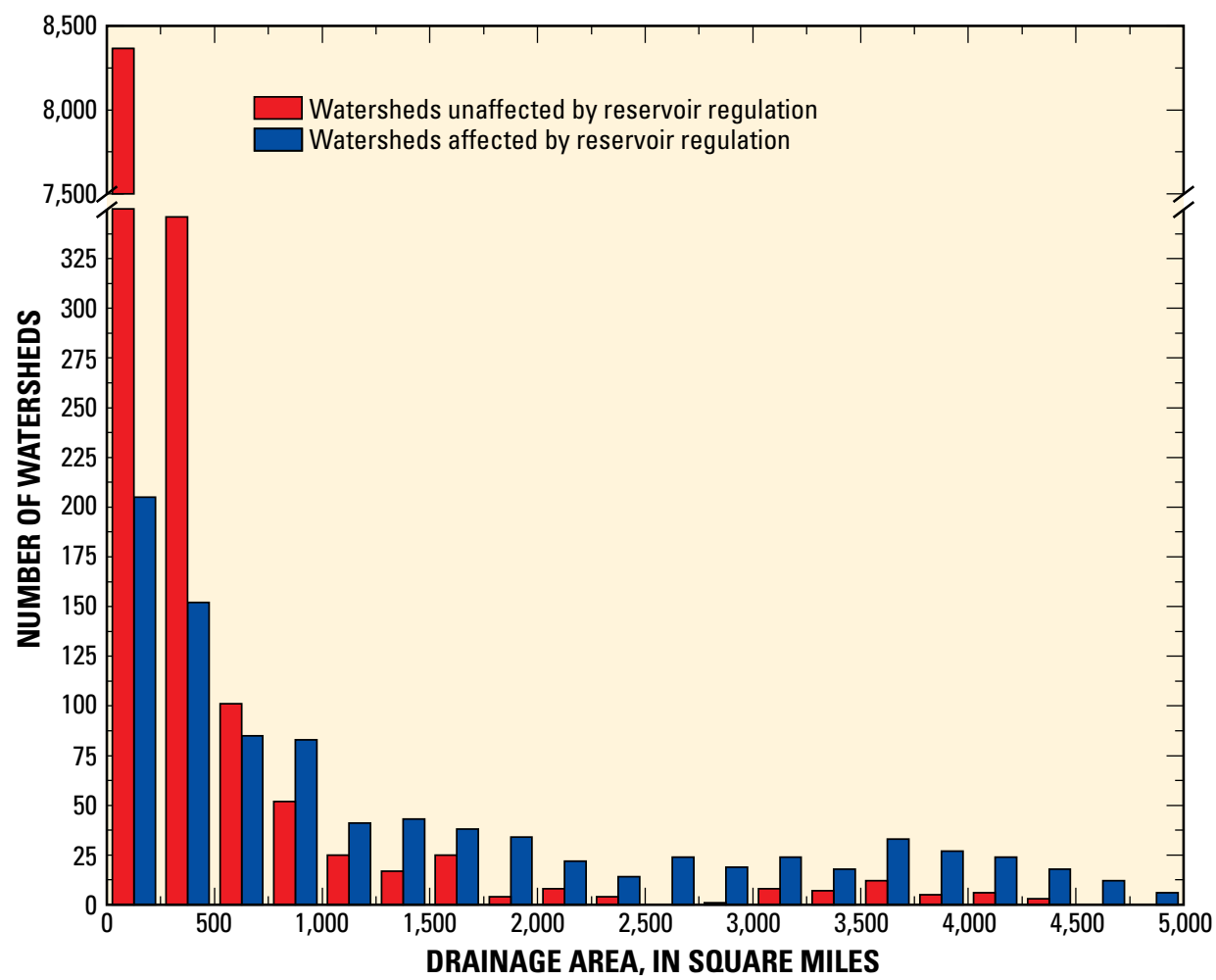

Figure 10. Number of watersheds in the Upper Colorado River Basin with drainage areas less than 5,000 square miles. 
gages to unregulated UCRB watersheds is at least 10 percent across the range of values of the watershed characteristic, then the USGS streamgage network is considered to represent that watershed characteristic. For the unregulated active USGS streamgage network, a criterion of 2 percent of the unregulated UCRB watersheds across the range of values for the watershed characteristic is used.

For regulated watersheds, the USGS streamgage network measures streamflow in about 17 percent of regulated UCRB watersheds (226 gages and 1,353 watersheds), and the active gaging station network measures streamflow in about 7.2 percent (98 gages and 1,353 watersheds) of the watersheds. Therefore, if the ratio of regulated USGS gages to regulated UCRB watersheds is at least 20 percent across the range of values for a specific watershed characteristic then the USGS streamgage network is considered to represent that watershed characteristic. The criterion of 10 percent is used for the ratio of regulated active USGS streamgages to regulated UCRB watersheds.

\section{Watershed Characteristics}

As discussed above, drainage area is a fundamental physical characteristic of a watershed that is commonly used to classify watersheds and is the basis from which many other watershed characteristics are calculated. For example, the percentage of a watershed covered by forest is computed in relation to the drainage area of the watershed; area covered by forest divided by the total area of the watershed. The discussion of watershed characteristics that follows in this section of the report is presented in terms of drainage area.

For this analysis, 16 watershed characteristics and one climatic characteristic were computed for the 1,053 watersheds with USGS streamgages and 10,338 watersheds in the UCRB using geographic information system (GIS) techniques (table 2). These characteristics include physiographic watershed attributes, such as mean basin elevation; land cover parameters, such as percentage of basin covered by evergreen forest; parameters that can assist in evaluating the anthropogenic influence upon basins, such as population density and

Table 2. Watershed and climatic characteristics.

[NED, National Elevation Dataset; PRISM, Parameter-elevation Regressions on Independent Slopes Model; NLCD, National Land Cover Dataset]

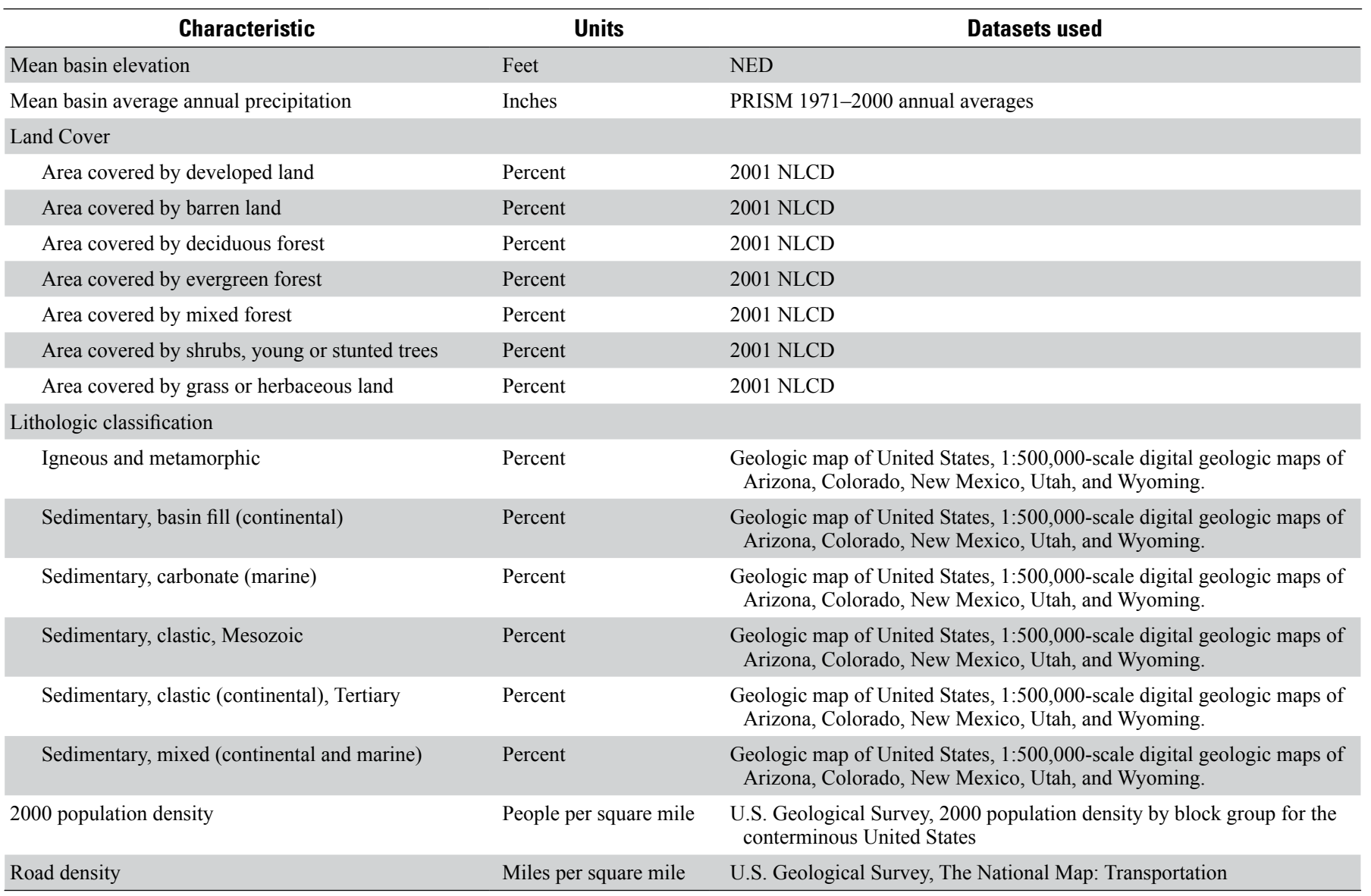


road density; and bedrock lithology. The watershed characteristics were selected to generally examine the physical, ecological, and climatological aspects of watersheds in the UCRB to assess how well the USGS streamgage network has monitored the spectrum of watersheds within the basin. The selected watershed characteristics are also widely used in hydrologic, biologic, and ecological studies of watersheds. The watersheds of the UCRB are further partitioned as either regulated or unregulated.

\section{Elevation}

Elevation in the UCRB ranges from $14,400 \mathrm{ft}$ near the Continental Divide in Colorado to about 3,200 ft at Lees Ferry, Arizona. The mean elevation for the UCRB is 7,070 ft. Mean watershed elevation was computed for unregulated (fig. 11) and regulated (fig. 12) watersheds with USGS streamgages and watersheds in the UCRB.
The comparison between unregulated watersheds with USGS gages and UCRB watersheds for mean drainage basin elevation is shown in figure 11. In the scatter plot, unregulated watersheds with USGS gages are fairly evenly distributed across the range of drainage area and mean elevations of UCRB watersheds with one exception. A small gap in the entire USGS streamgage network exists for watersheds between 20 and $70 \mathrm{mi}^{2}$ with mean drainage basin elevations between 5,000 and $6,000 \mathrm{ft}$, indicating that the USGS streamgage network underrepresents watersheds in this mean elevation range and drainage area. Watersheds instrumented with active USGS gages are more common in watersheds with mean basin elevations greater than about 7,000 ft, indicating a bias in the active USGS streamgage network toward high elevation watersheds. Further, no less than 20 percent of the UCRB watersheds with mean basin elevations greater than 9,000 ft have been monitored by a USGS gaging station, whereas less than 5 percent of watersheds with a mean

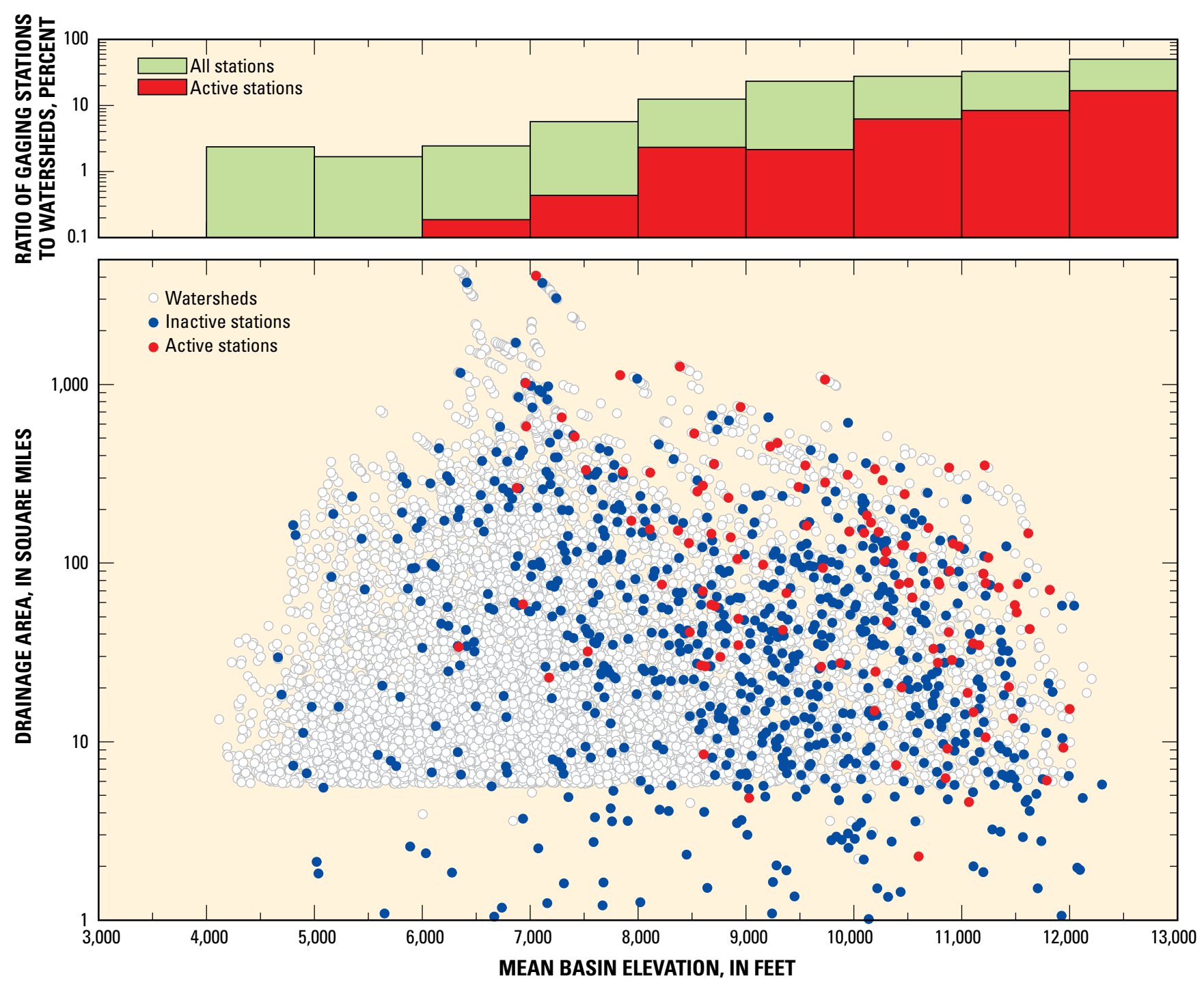

Figure 11. Mean drainage basin elevation for watersheds and U.S. Geological Survey streamgage locations in the Upper Colorado River Basin that are unaffected by reservoir regulation. 


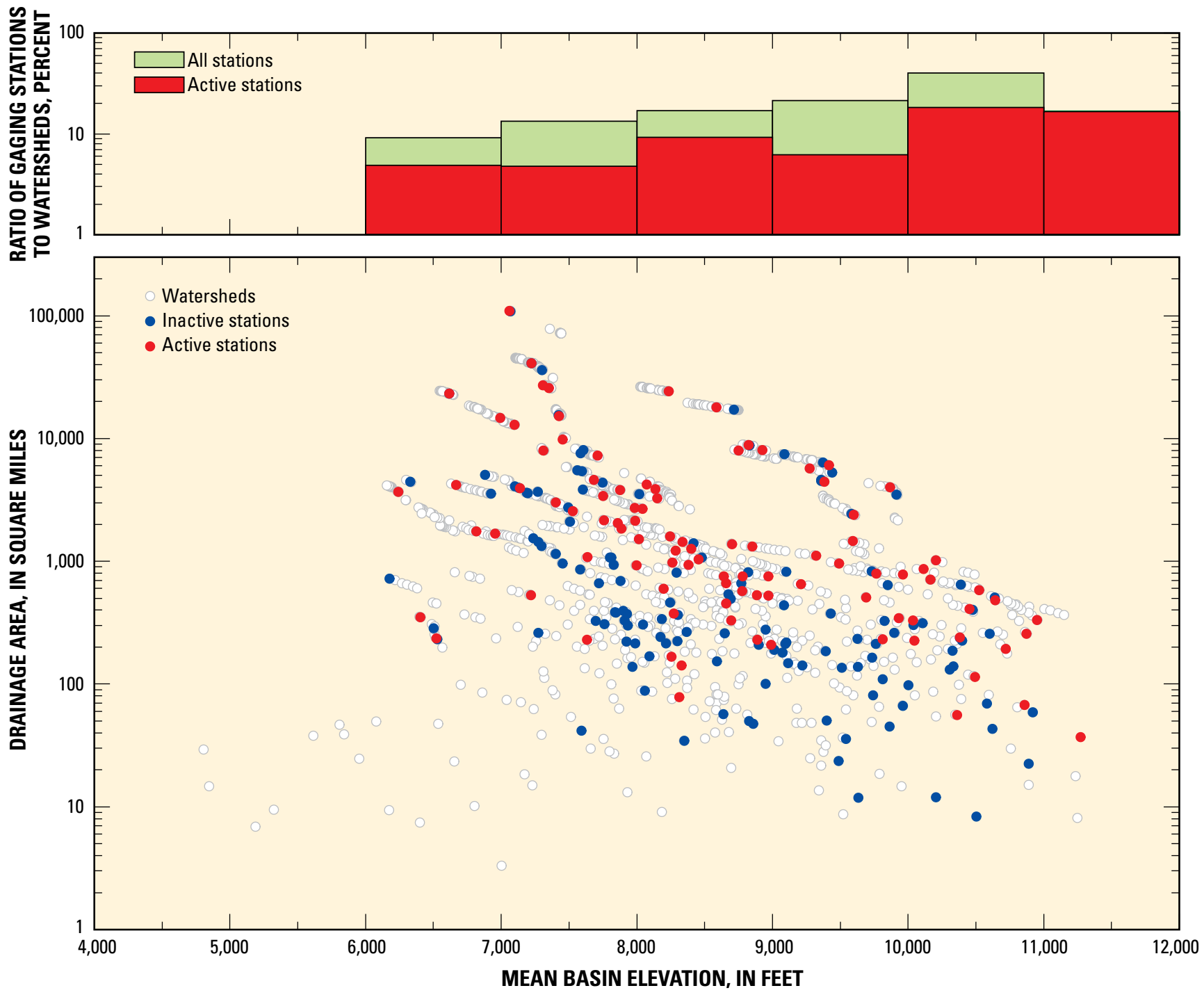

Figure 12. Mean drainage basin elevation for watersheds and U.S. Geological Survey streamgage locations in the Upper Colorado River Basin that are affected by reservoir regulation.

elevation of less than $8,000 \mathrm{ft}$ have been monitored by a USGS gaging station. Therefore, small unregulated drainage basins with low mean basin elevations are not being represented well by the streamgage network in the UCRB.

Regulated watersheds typically have watershed areas greater than $100 \mathrm{mi}^{2}$ and mean basin elevations greater than $8,000 \mathrm{ft}$ (fig. 12). The distribution of mean basin elevations for the regulated active USGS gages is similar to the distribution for the regulated inactive streamgage locations. Approximately 10 percent or more of the regulated UCRB watersheds with mean basin elevations greater than $6,000 \mathrm{ft}$ have been monitored by a USGS streamgage and approximately 5 percent or more are being monitored currently.

\section{Mean Annual Precipitation}

The estimated annual precipitation in the UCRB ranges from about 50 in., mostly as snow, near the Continental Divide to about $10 \mathrm{in}$. on the Colorado Plateau. Mean watershed average annual precipitation was computed from PRISM (Precipitation-elevation Regressions on Independent Slopes Model) mean annual precipitation data for 1971-2000 (PRISM Group, Oregon State University, 2007) for unregulated (fig. 13) and regulated (fig. 14) UCRB watersheds and USGS streamgages.

On the basis of a criterion of 10 percent of unregulated UCRB watersheds with USGS streamgages and 2 percent of unregulated watersheds with active USGS streamgages, the USGS streamgage network and active USGS streamgages underrepresent UCRB watersheds having mean annual precipitation less than 25 in. For watersheds with an average annual precipitation greater than 25 in., the USGS streamgage 


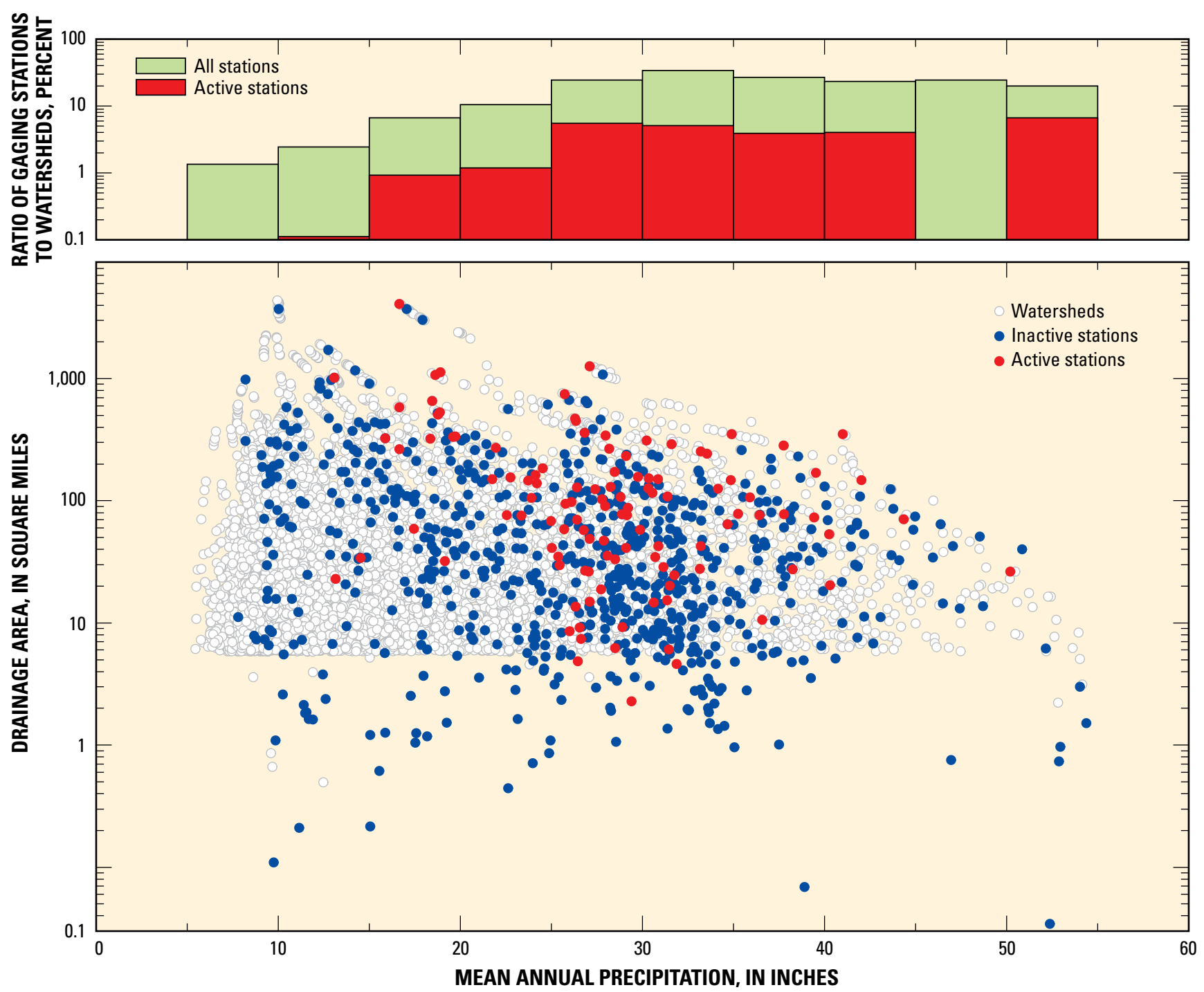

Figure 13. Mean annual precipitation for watersheds and U.S. Geological Survey streamgages in the Upper Colorado River Basin that are unaffected by reservoir regulation.

network and active USGS gages exceed the criteria for representing the UCRB watersheds. This overrepresentation can be explained in part by the fact that in the UCRB, many watersheds at lower elevations with low mean annual precipitation have ephemeral streams. Ephemeral streams are less likely to be measured as part of the USGS streamgage network because there is less interest in low amounts of streamflow. Conversely, surface-water resources in the UCRB generally are associated with higher elevation areas having greater average annual precipitation. As a result, USGS streamgages are more likely to be located in these watersheds.

For regulated watersheds, both the entire USGS streamgage network and active USGS gages underrepresent UCRB watersheds having a mean annual precipitation of less than 20 in. (fig. 14). In contrast, watersheds with an average annual precipitation greater than $20 \mathrm{in}$. are represented well by the USGS streamgage network, including the active gages.

\section{Land Cover}

The vegetation and ecology of the UCRB vary primarily because of differences in elevation, latitude, and climate. Because it is important to take ecological issues into account as the region develops, the extent to which the USGS streamgage network represents these various landscapes is important for managing water, land, and ecological resources. The 2001 National Land Cover Dataset (NLCD; Homer and others, 2004) provides a geospatial classification of land cover for the Nation. The NLCD classes of land cover in the UCRB used in this assessment include developed land, barren land, deciduous forest, evergreen forest, mixed forest, shrubscrub land, and grass or herbaceous land (fig. 15). These land cover classes are described in table 3 . The developed lands class is a sum of the four developed land classifications in the NLCD: developed open space, developed low intensity, developed medium intensity, and developed high intensity. 

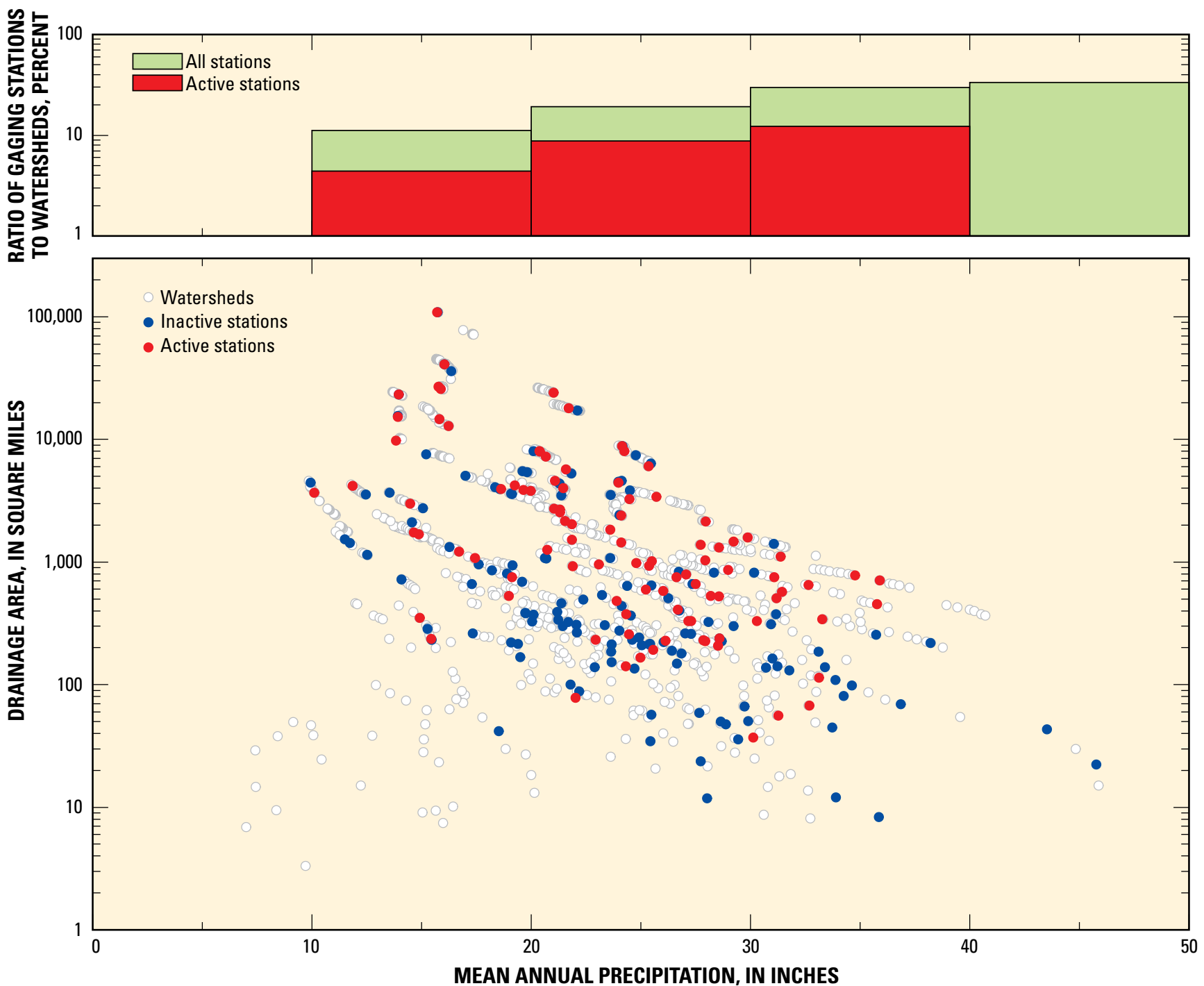

Figure 14. Mean annual precipitation for watersheds and U.S. Geological Survey streamgages in the Upper Colorado River Basin that are affected by reservoir regulation.

Table 3. Description of land cover classifications from the National Land Cover Dataset.

Developed: Areas characterized by a high percentage (30 percent or greater) of constructed materials (e.g., asphalt, concrete, buildings, etc.).

Barren Land (Rock/Sand/Clay): Barren areas of bedrock, desert pavement, scarps, talus, slides, volcanic material, glacial debris, sand dunes, strip mines, gravel pits and other accumulations of earthen material. Generally, vegetation accounts for less than 15 percent of total cover.

Deciduous Forest: Areas dominated by trees generally greater than 5 meters tall and composing greater than 20 percent of total vegetation cover. More than 75 percent of the tree species shed foliage simultaneously in response to seasonal change.

Evergreen Forest: Areas dominated by trees generally greater than 5 meters tall and composing greater than 20 percent of total vegetation cover. More than 75 percent of the tree species maintain their leaves all year. Canopy is never without green foliage.

Mixed Forest: Areas dominated by trees generally greater than 5 meters tall and composing greater than 20 percent of total vegetation cover. Neither deciduous nor evergreen species are greater than 75 percent of total tree cover.

Shrub/Scrub: Areas dominated by shrubs less than 5 meters tall with shrub canopy typically composing greater than 20 percent of total vegetation. This class includes true shrubs, young trees in an early successional stage, or trees stunted from environmental conditions.

Grassland/Herbaceous: Areas dominated by grammanoid or herbaceous vegetation generally composing greater than 80 percent of total vegetation. These areas are not subject to intensive management such as tilling, but can be utilized for grazing. 


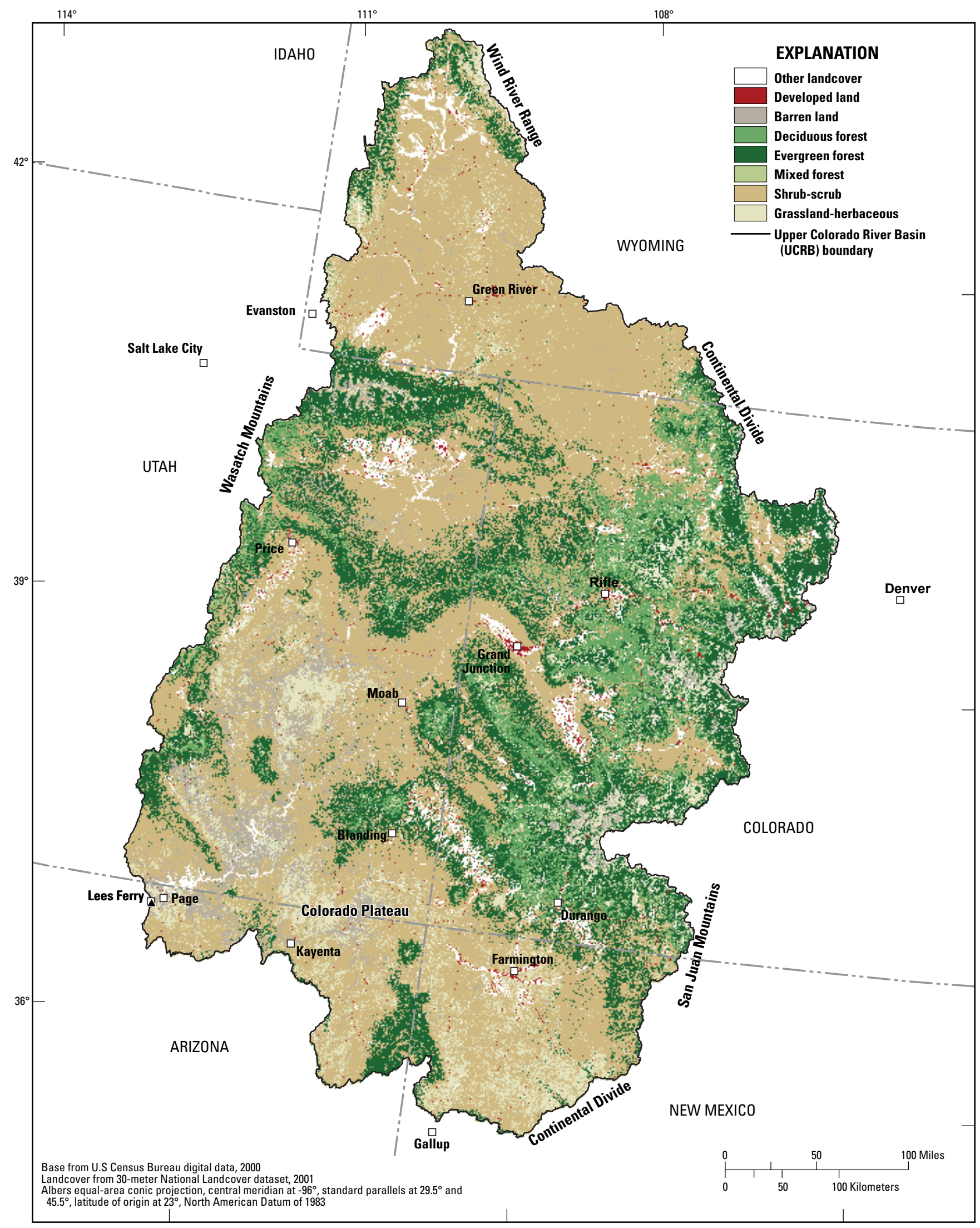

Figure 15. Distribution of seven land cover classifications from the National Land Cover Dataset for the Upper Colorado River Basin. 
The percentage of the drainage area covered by each of the seven land classifications was computed for unregulated and regulated UCRB watersheds both instrumented and not instrumented with USGS streamgages (figs. 16 through 29). The most prevalent land cover in the UCRB is shrub-scrub, which accounts for about 50 percent of the land cover. Conversely, lands classified as developed compose about 1 percent of the total land cover in the UCRB. The land cover characteristics, as well as their distribution in watersheds of various sizes in the UCRB, are presented in figures 16 through 29.

For unregulated watersheds, the USGS streamgage network generally is not evenly distributed across the drainage basin area for the land cover classes, except in the cases of deciduous and evergreen forest land cover (figs. 16 and 17). USGS streamgages, including active gages, are not as evenly distributed across drainage basin size and percent of land cover for the other five land cover classes in unregulated watersheds as the forest cover types (figs. 18-22). For the shrub-scrub class, the most prevalent land cover class in the UCRB, the USGS streamgage network usually better represents watersheds with less than 20 percent shrub-scrub land cover than ones with greater shrub-scrub coverage (fig. 18). This could be because watersheds dominated by shrub-scrub are at lower elevations and tend to be drier, which would suggest that there are fewer perennial streams. This same pattern and explanation can apply to the barren land and grassland classes as well (figs. 19 and 20). The biases visible in the graphs most likely are a function of the distribution of water within the UCRB and thus, within the watershed dataset. It is important to understand that although a watershed has been delineated, this does not mean there is perennial flow in the watershed to measure. For unregulated watersheds, the USGS streamgage network is more representative of the UCRB landscape when the drier land cover classes (shrub-scrub, grassland, and barren land) compose relatively small percentages of the total land cover.

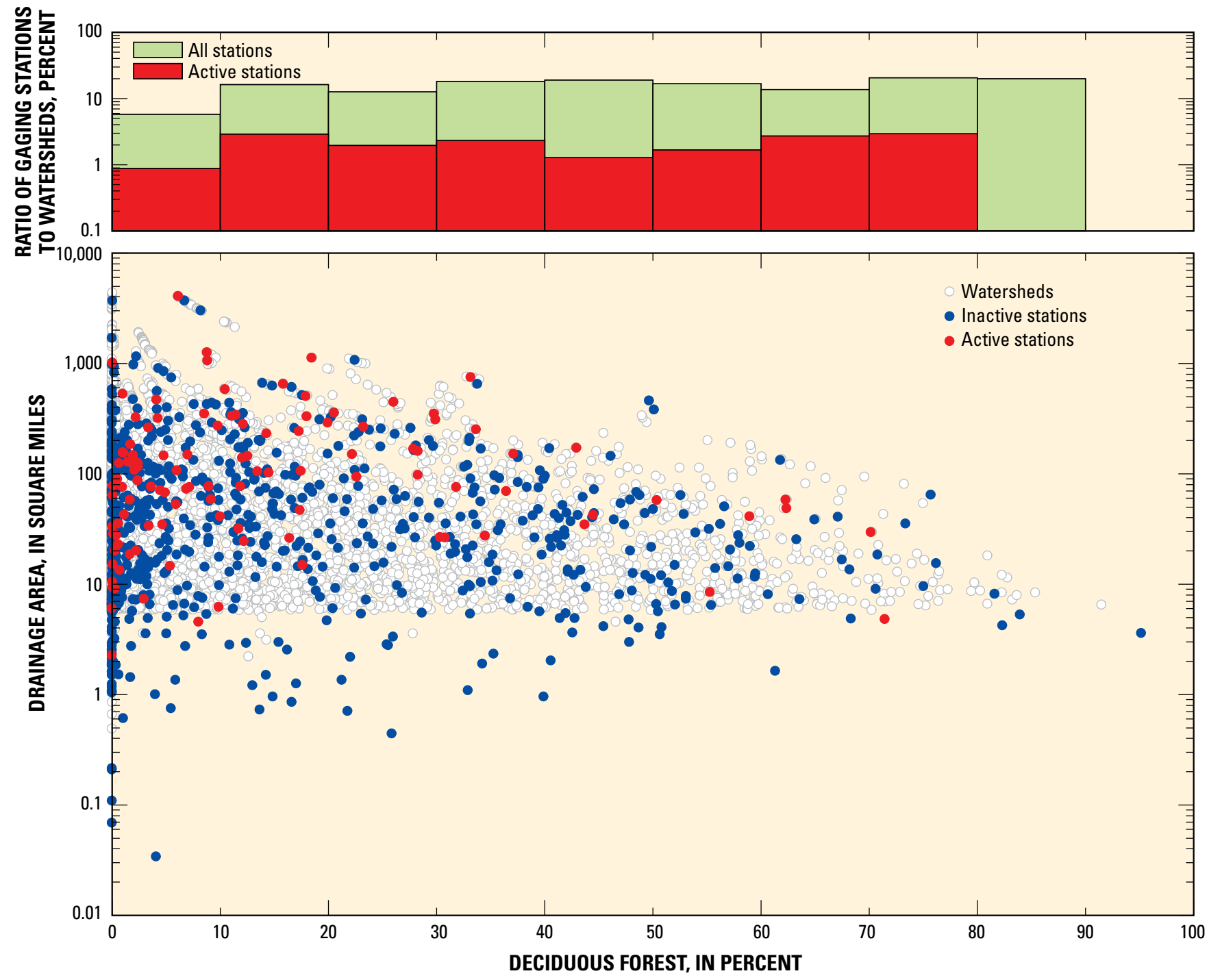

Figure 16. Percentage of drainage area covered by deciduous forest for watersheds and U.S. Geological Survey streamgages in the Upper Colorado River Basin that are unaffected by reservoir regulation. 


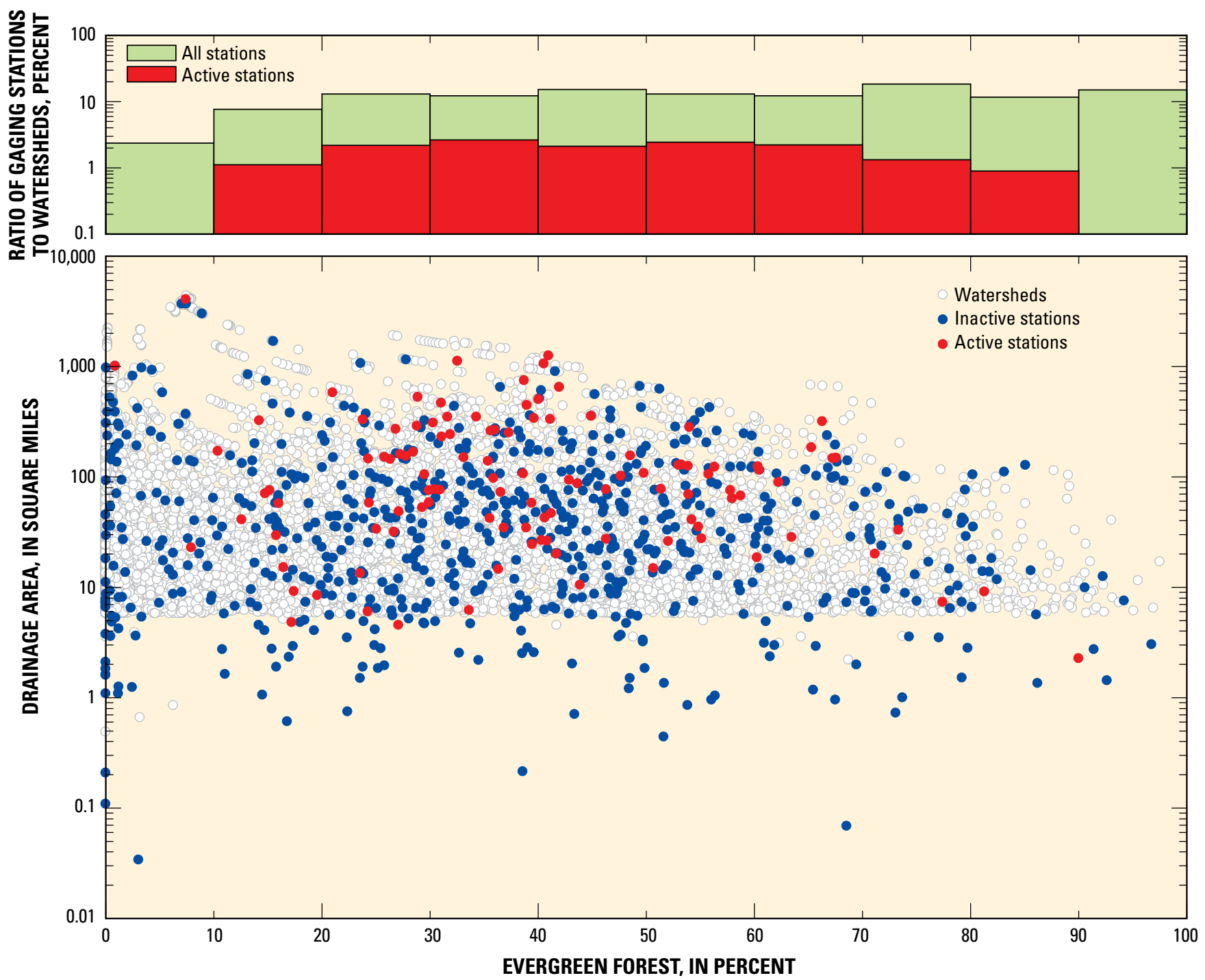

Figure 17. Percentage of drainage area covered by evergreen forest for watersheds and U.S. Geological Survey streamgages in the Upper Colorado River Basin that are unaffected by reservoir regulation. 


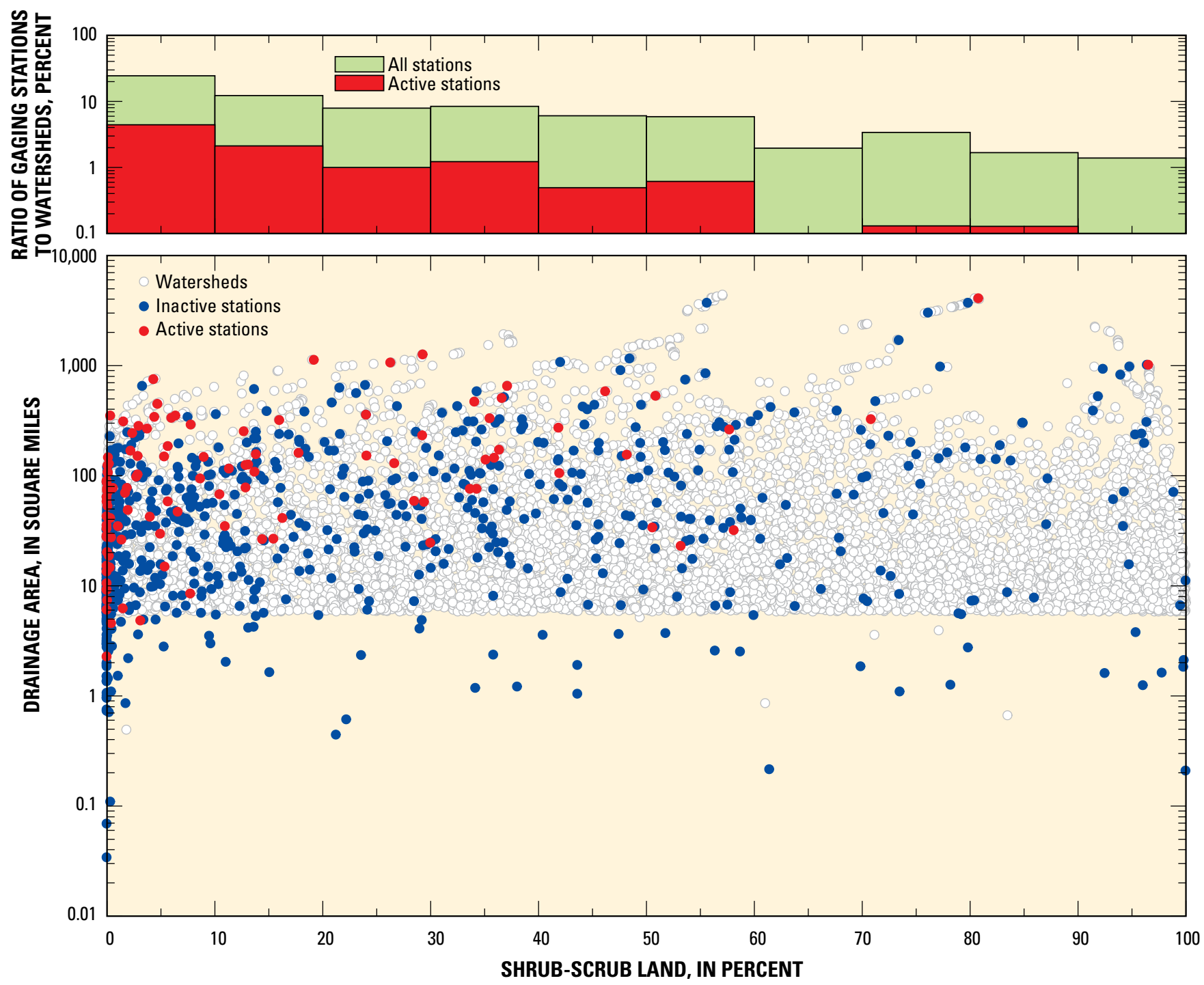

Figure 18. Percentage of drainage area covered by shrubs, young or stunted trees, for watersheds and U.S. Geological Survey streamgages in the Upper Colorado River Basin that are unaffected by reservoir regulation. 


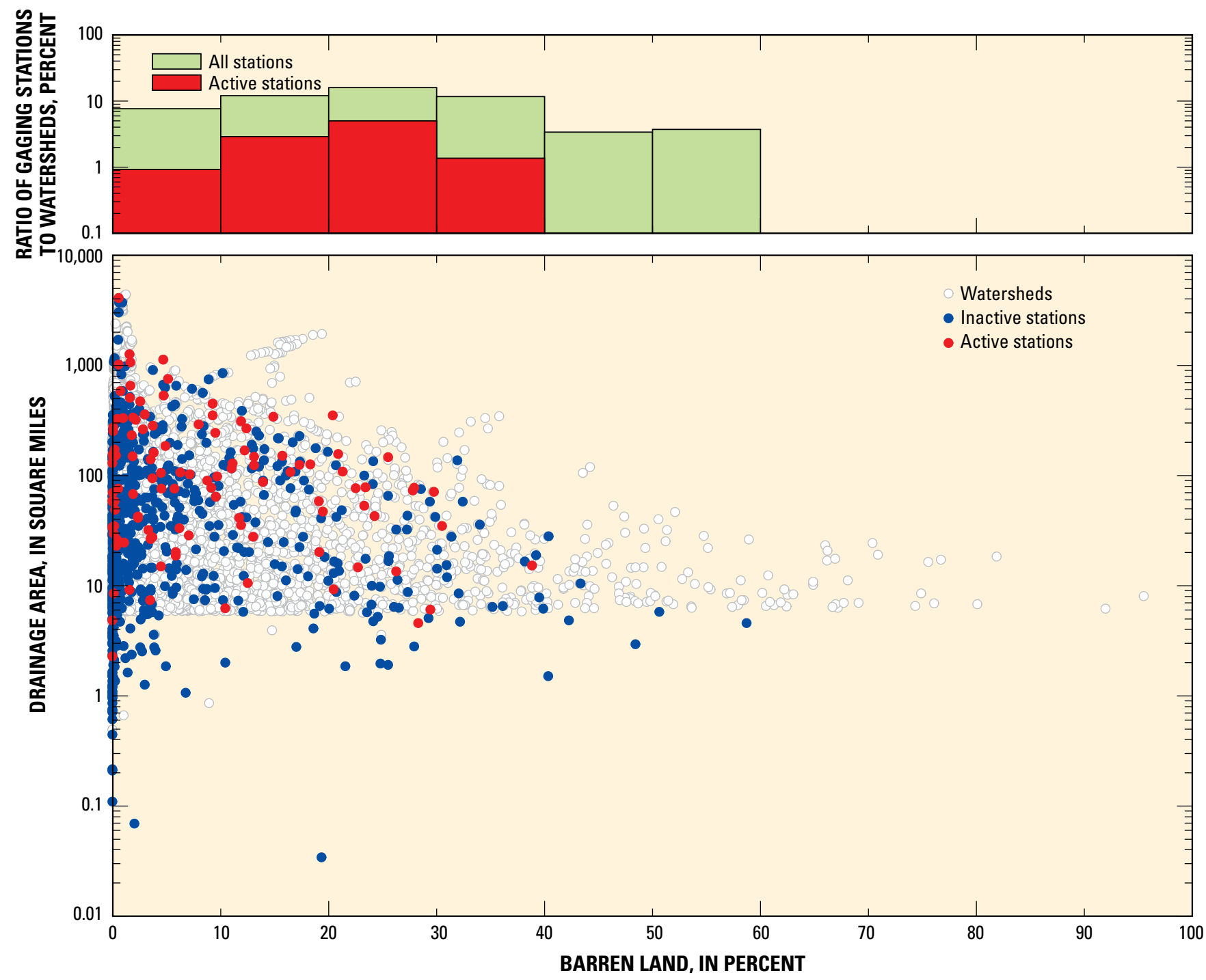

Figure 19. Percentage of drainage area covered by barren land for watersheds and U.S. Geological Survey streamgages in the Upper Colorado River Basin that are unaffected by reservoir regulation. 


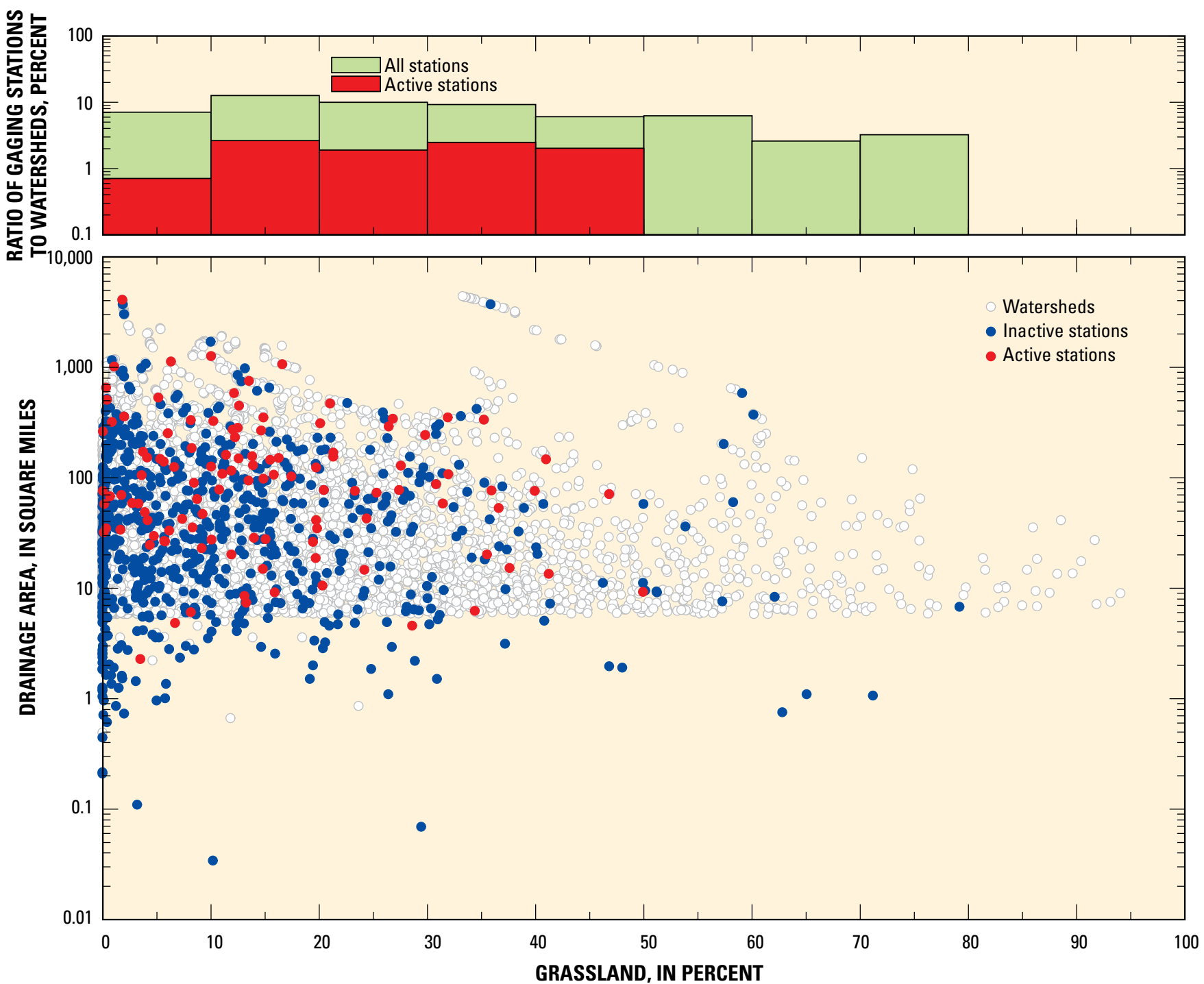

Figure 20. Percentage of drainage area covered by grass or herbaceous land for watersheds and U.S. Geological Survey streamgages in the Upper Colorado River Basin that are unaffected by reservoir regulation. 


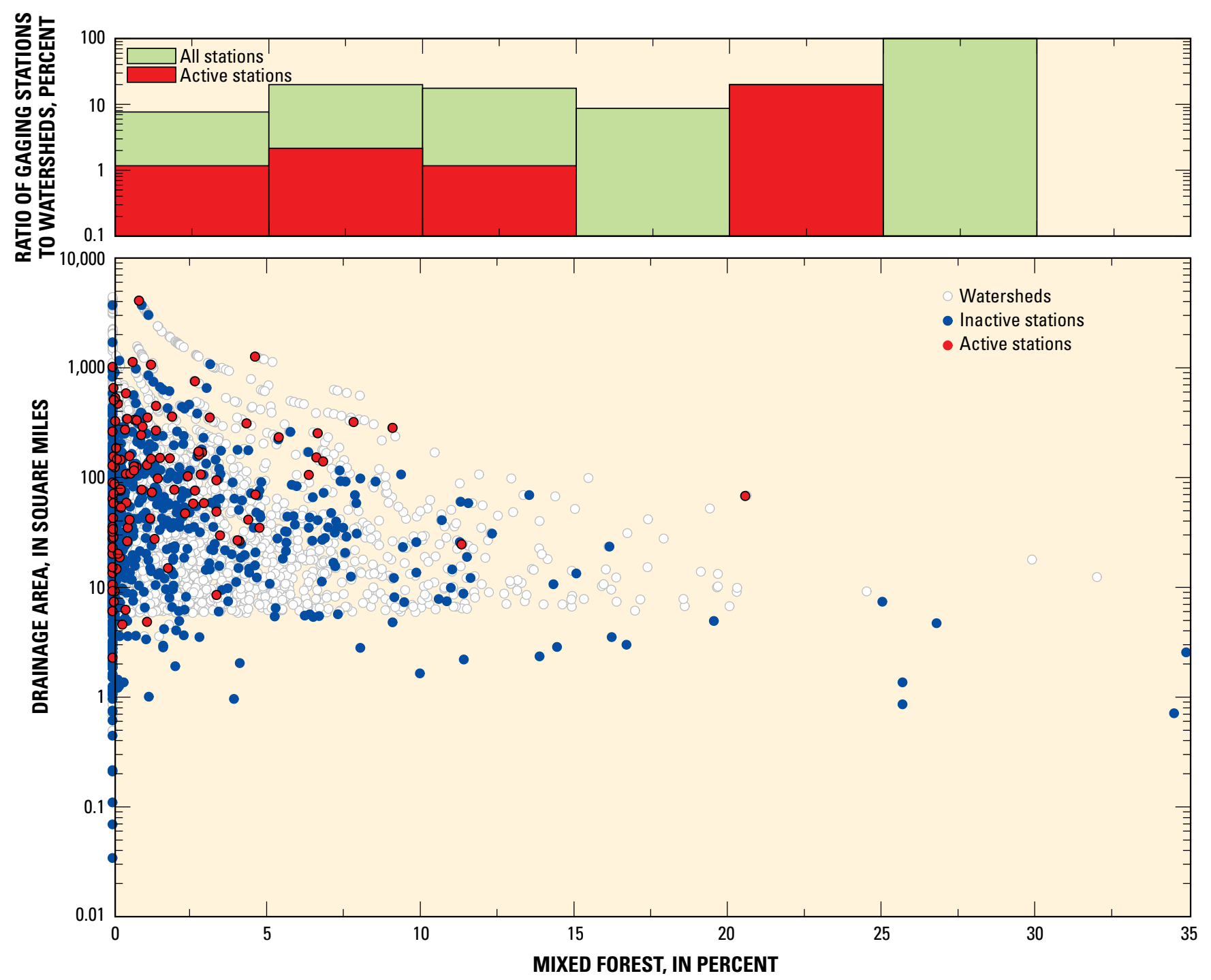

Figure 21. Percentage of drainage area covered by mixed forest for watersheds and U.S. Geological Survey streamgages in the Upper Colorado River Basin that are unaffected by reservoir regulation. 


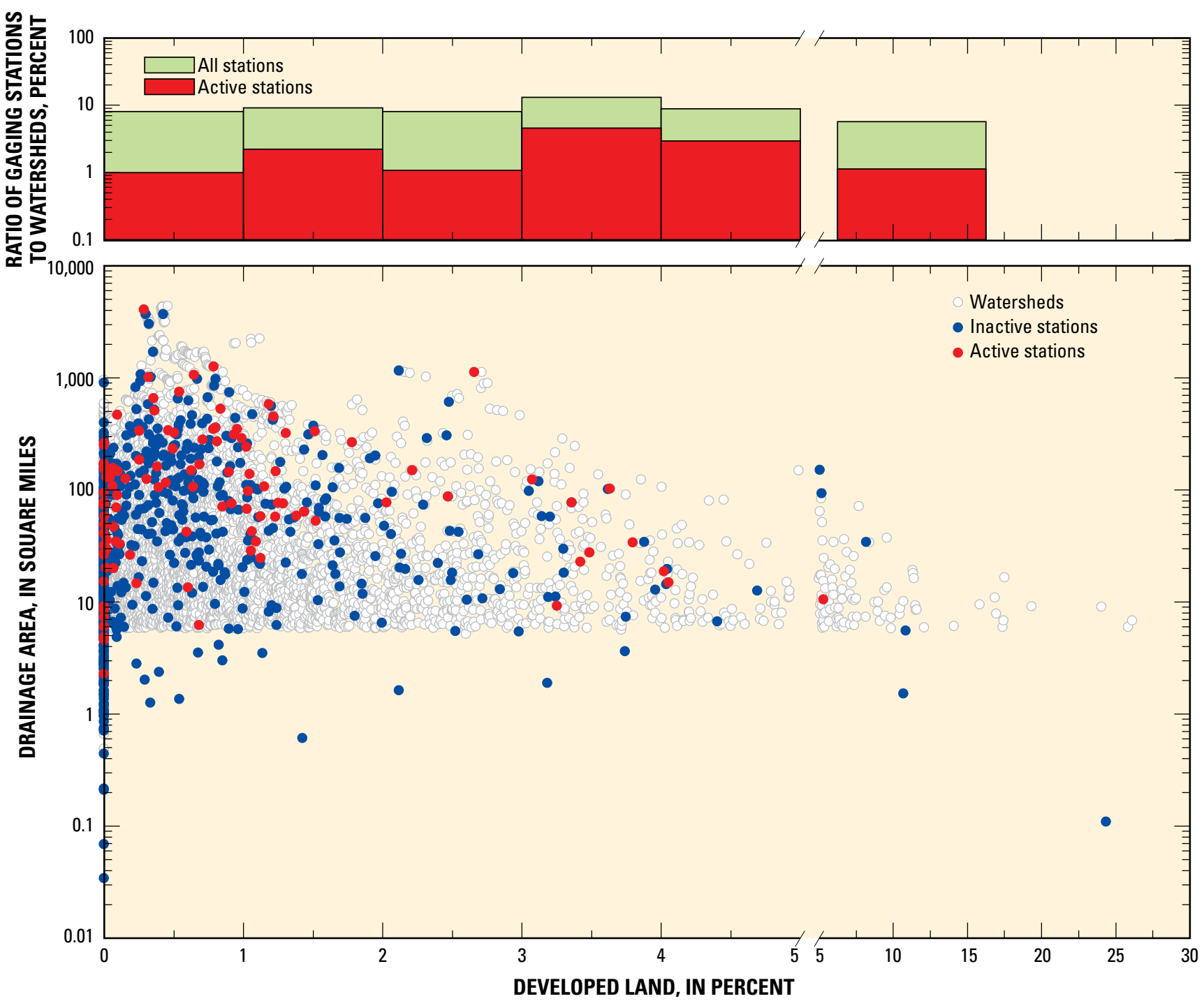

Figure 22. Percentage of drainage area covered by developed land for watersheds and U.S. Geological Survey streamgages in the Upper Colorado River Basin that are unaffected by reservoir regulation. 


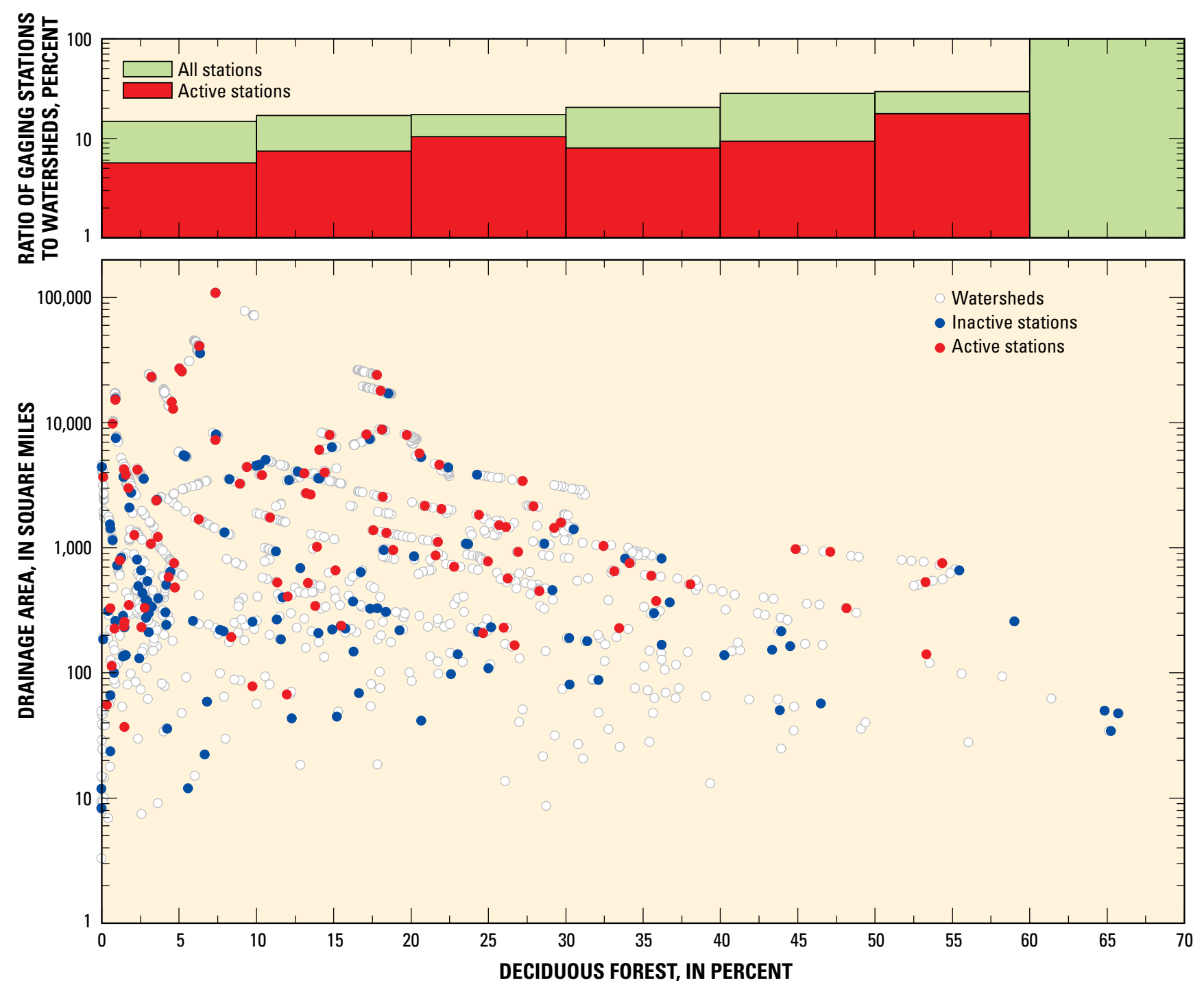

Figure 23. Percentage of drainage area covered by deciduous forest for watersheds and U.S. Geological Survey streamgages in the Upper Colorado River Basin that are affected by reservoir regulation. 


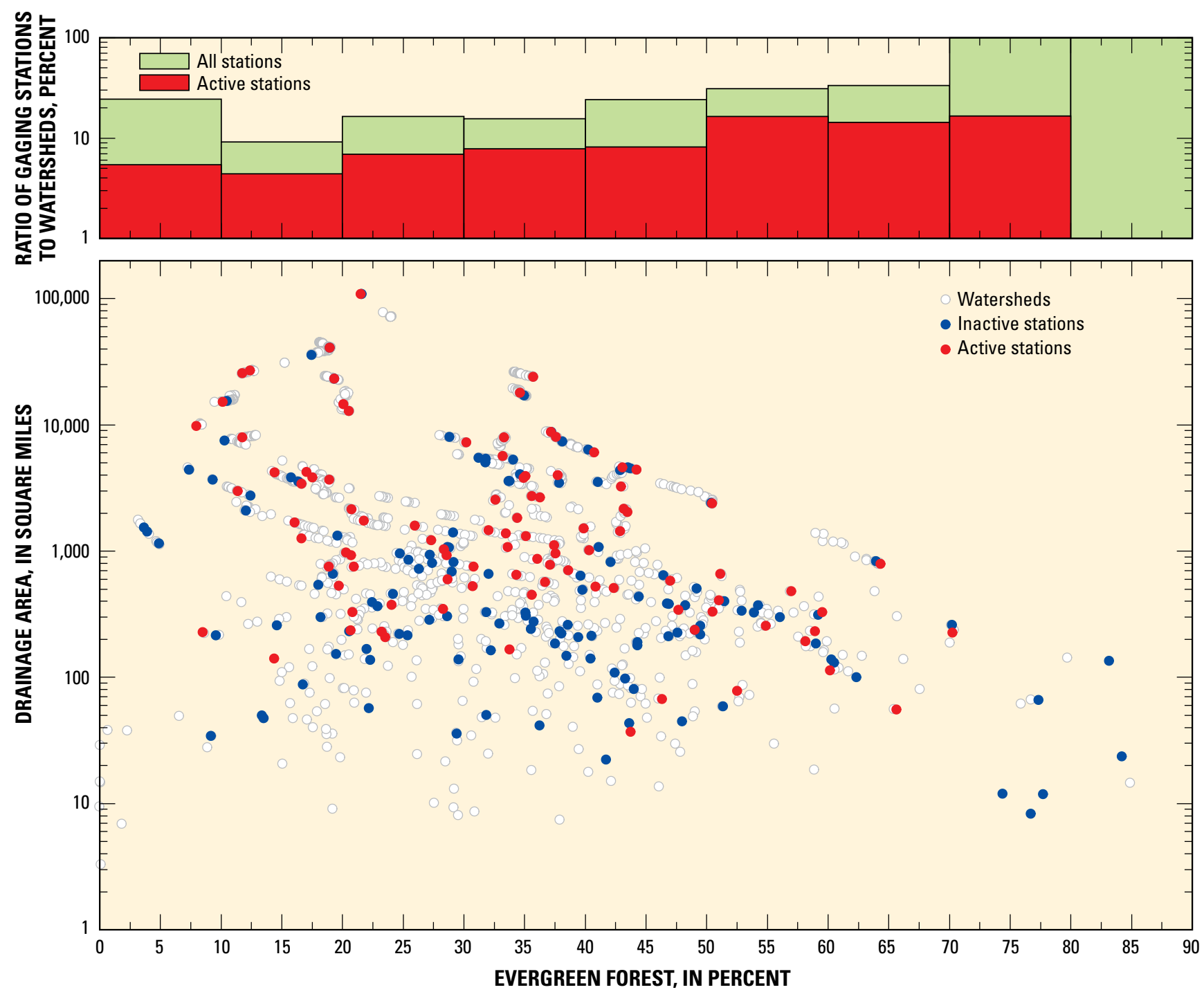

Figure 24. Percentage of drainage area covered by evergreen forest for watersheds and U.S. Geological Survey streamgages in the Upper Colorado River Basin that are affected by reservoir regulation. 

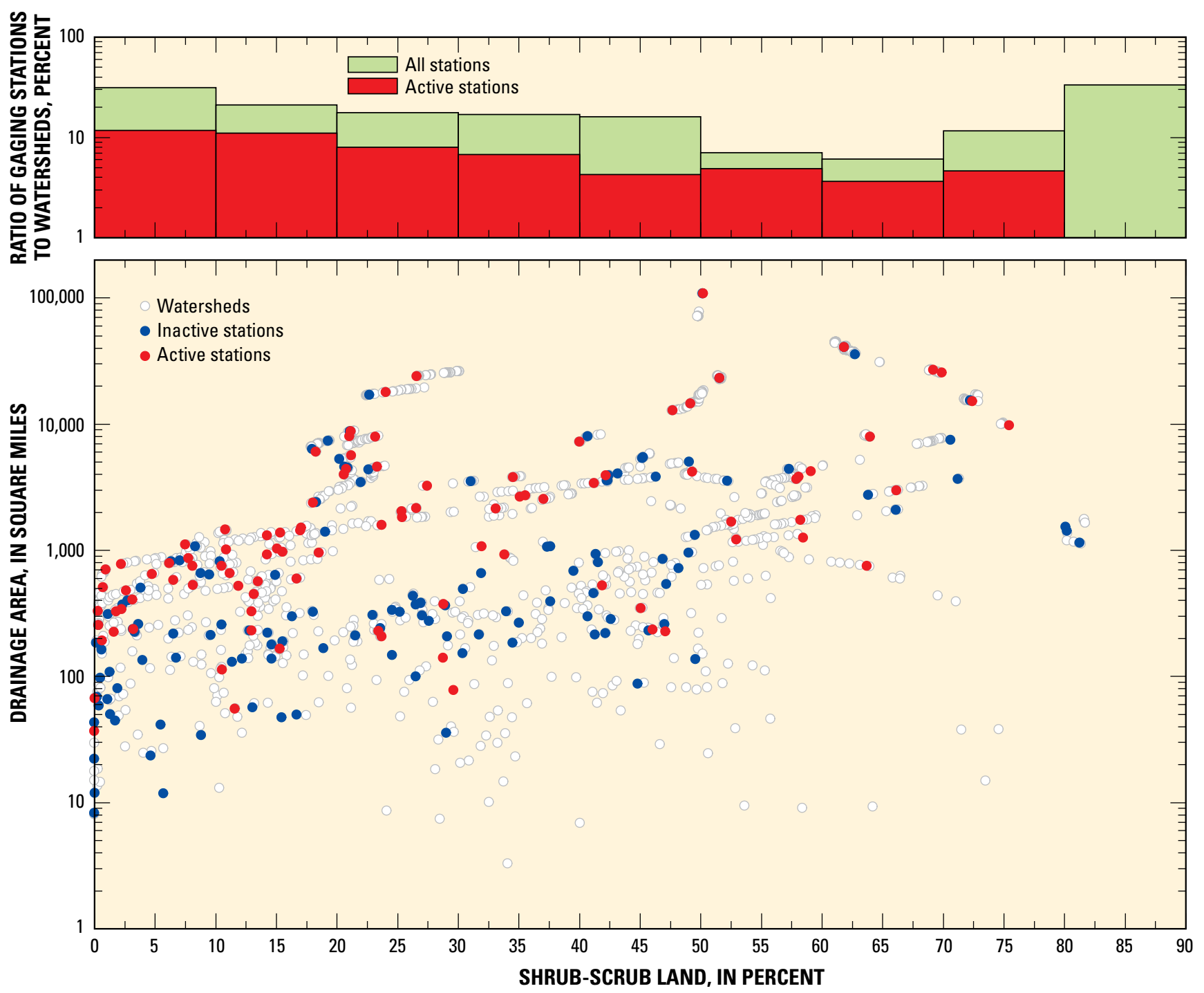

Figure 25. Percentage of drainage area covered by shrubs, young or stunted trees for watersheds and U.S. Geological Survey streamgages in the Upper Colorado River Basin that are affected by reservoir regulation. 


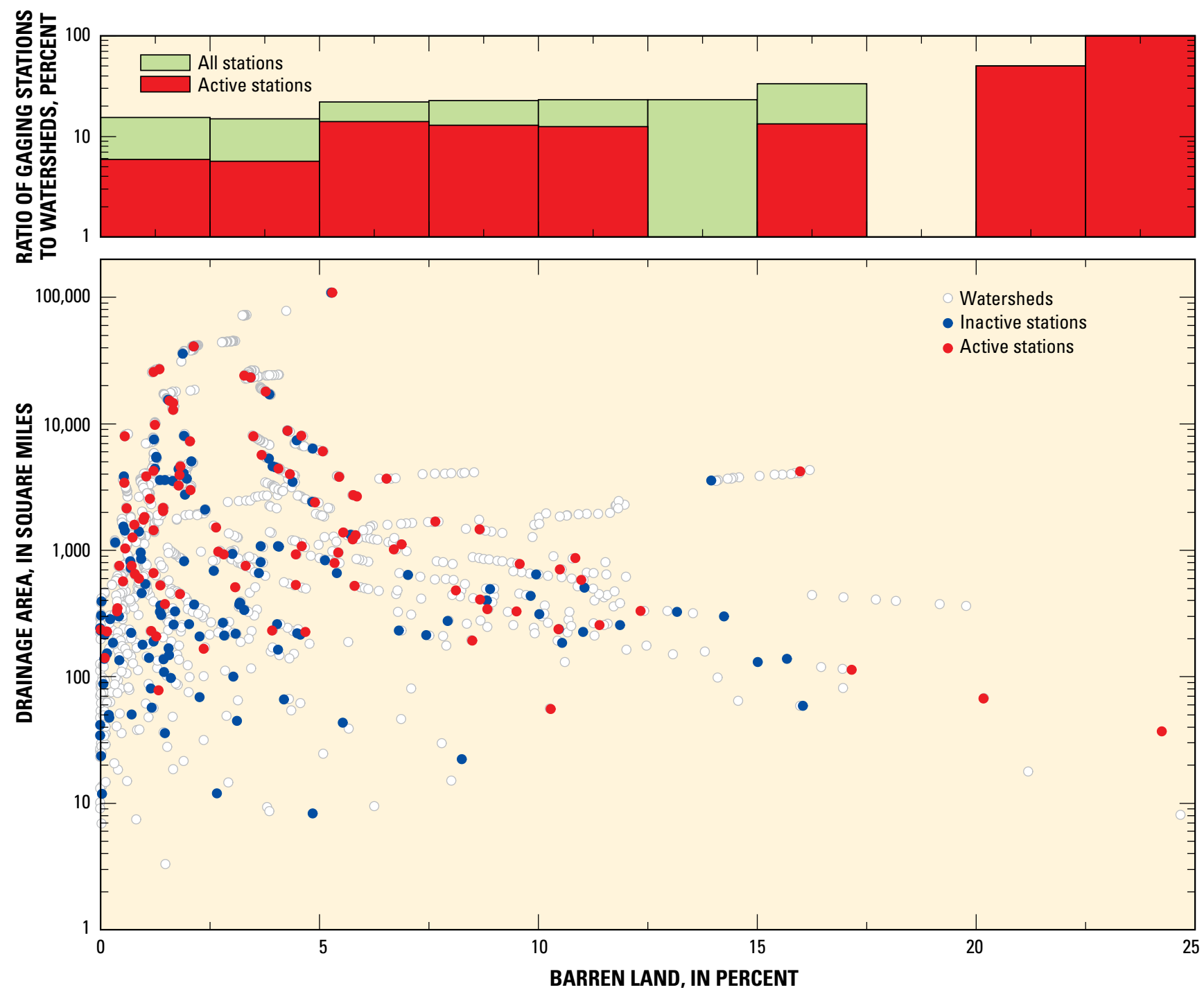

Figure 26. Percentage of drainage area covered by barren land for watersheds and U.S. Geological Survey streamgages in the Upper Colorado River Basin that are affected by reservoir regulation. 


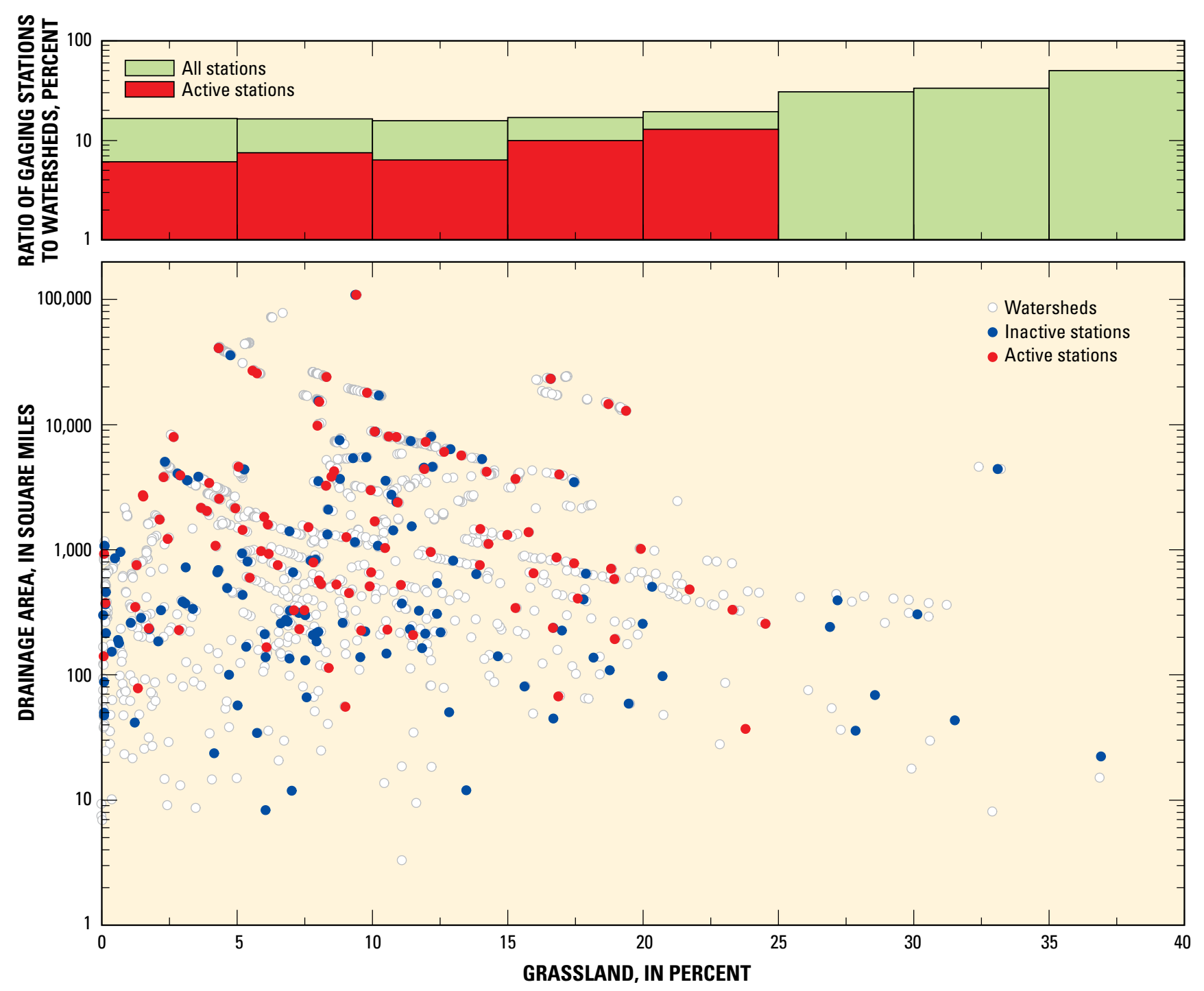

Figure 27. Percentage of drainage area covered by grass or herbaceous land for watersheds and U.S. Geological Survey streamgages in the Upper Colorado River Basin that are affected by reservoir regulation. 


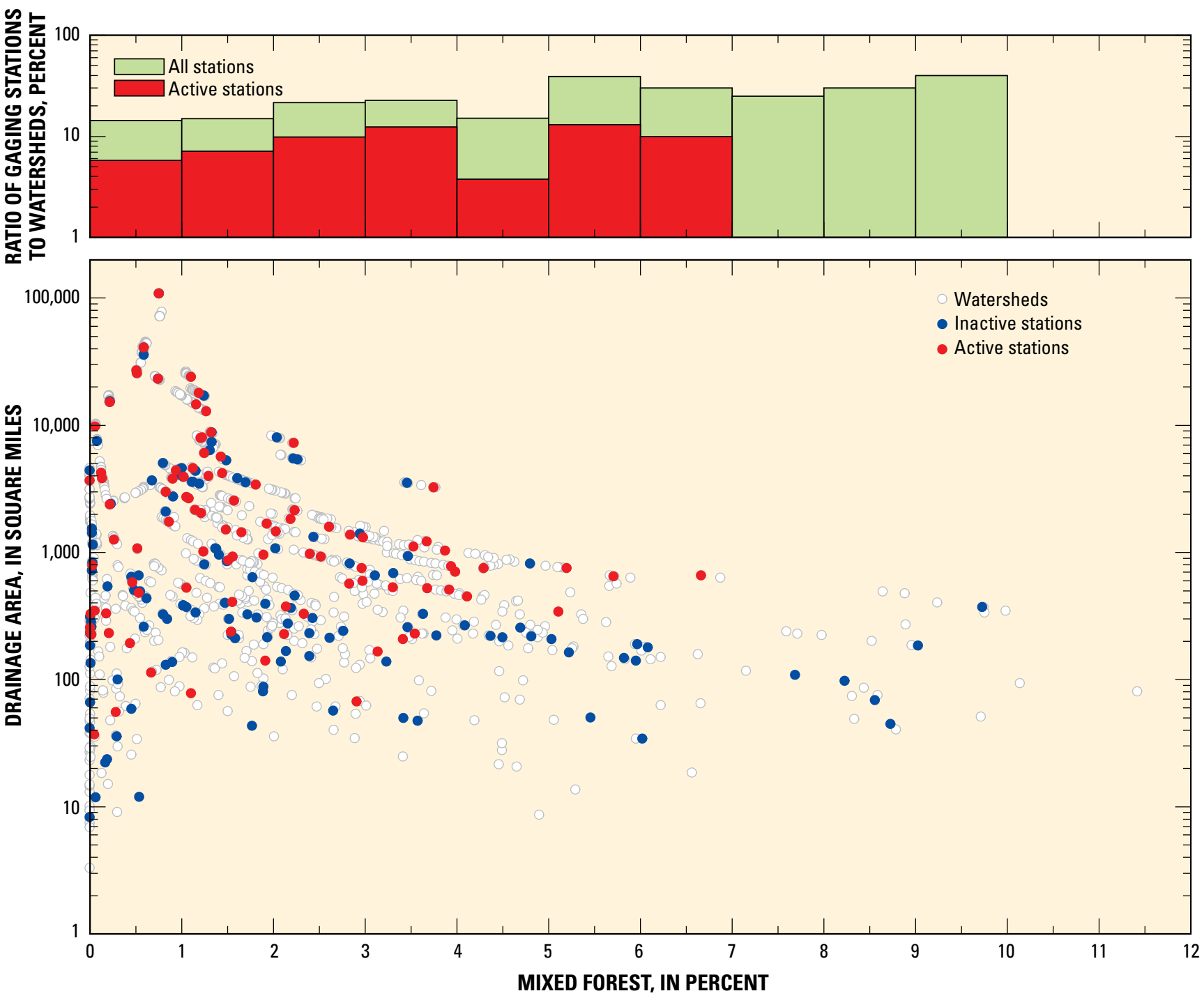

Figure 28. Percentage of drainage area covered by mixed forest for watersheds and U.S. Geological Survey streamgages in the Upper Colorado River Basin that are affected by reservoir regulation. 


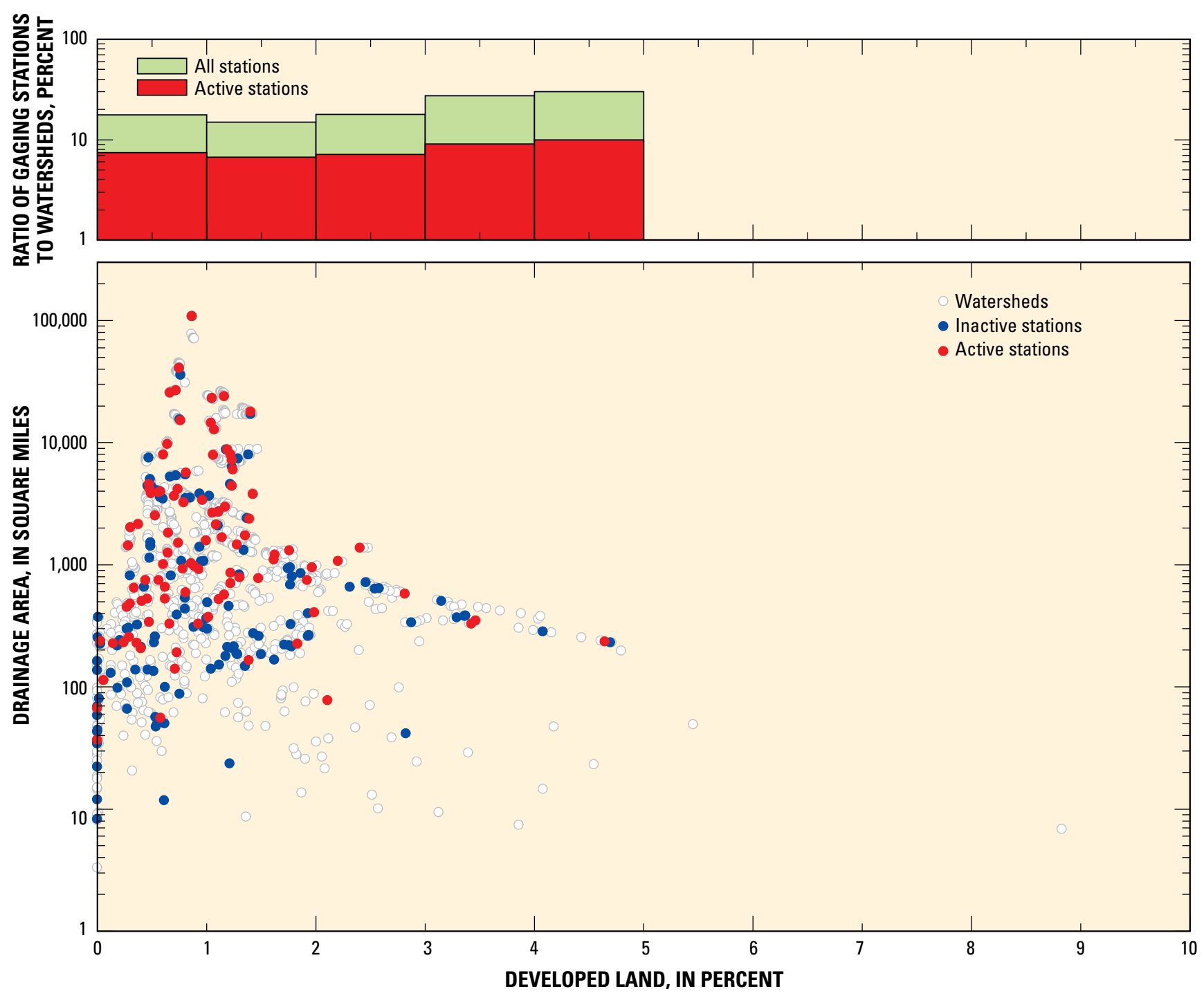

Figure 29. Percentage of drainage area covered by developed land for watersheds and U.S. Geological Survey streamgages in the Upper Colorado River Basin that are affected by reservoir regulation.

Similarly, regulated watersheds instrumented with USGS streamgages tend to represent well the deciduous and evergreen forest classes for UCRB watersheds (figs. 23 and 24), although watersheds with active USGS gages slightly underrepresent UCRB watersheds for these two land cover classes. Watersheds with USGS streamgages, including active USGS gages, for the remaining five land cover classes underrepresent UCRB watersheds, with the exception of the developed land class (fig. 29). For the shrub-scrub land cover class, watersheds with greater than 50 percent shrub-scrub land cover are underrepresented (fig. 25).

\section{Bedrock Lithology}

The geology of the UCRB is diverse, encompassing the Wind River Mountains in Wyoming, the San Juan Mountains in Colorado, and the Uinta Mountains in Utah. The undeformed rocks of the Colorado Plateau, which generally covers the lower one-third of the UCRB, stand in distinct contrast to the highly deformed crustal blocks of the surrounding mountains. As part of this assessment of the USGS streamgage network, the bedrock geology of UCRB watersheds and watersheds with USGS streamgages was mapped and compared to evaluate how well the USGS streamgaging network represents the bedrock geology of watersheds in the UCRB. Six distinct lithologic classifications of bedrock (table 4) from a simplified 1:500,000 geologic map of the UCRB (Kenney and others, 2009) were developed (fig. 30). Because there are less than $9 \mathrm{mi}^{2}$ of sedimentary, basin-fill deposits (continental) in the UCRB, this lithology was not evaluated. The percentage of the drainage area for each of the remaining five lithologies was computed for unregulated and regulated watersheds with USGS streamgages and UCRB watersheds (figs. 31-40).

The lithologic classes sedimentary, clastic-Tertiary, and sedimentary, clastic-Mesozoic, account for about 80 percent of the bedrock geology in the UCRB, and the other lithologic 
classes account for about 5 to 10 percent each. In unregulated watersheds for these two lithologic classes, the USGS streamgage network and the active USGS network are representative of the watersheds in the UCRB, with the exception of watersheds having greater than 80 percent of either of these two classes (figs. 31 and 32). It is likely that these watersheds are within the Colorado Plateau at lower elevations, where there are few perennial streams and thus, fewer USGS gages. The USGS streamgage network and active USGS network underrepresent unregulated UCRB watersheds with small percentages (less than 10 percent) of the other three lithologic classes (figs. 33-35). In addition, the active USGS network does not represent the watersheds well at a variety of percentages for these three lithologic classes, indicating gaps in the active streamgage network. The USGS streamgage network and active USGS network exceed the criteria for representing the UCRB watersheds having $90-100$ percent igneous and metamorphic lithologies. Again, this can be a function of where perennial streams are located as many of these watersheds are dominated by snowmelt runoff at high elevations and thus, are more likely to contain perennial streamflow.

For regulated watersheds, the USGS streamgage network and active USGS network adequately represent UCRB watersheds for all lithologic classes, with the exception of the sedimentary, mixed (continental and marine) lithology. The active USGS gages were not representative of watersheds (figs 36-40) having 30-40 percent and 50-80 percent of the sedimentary, mixed (continental and marine) lithology (fig. 39).

\section{Population Density}

Anthropogenic activities in a watershed can cause changes in streamflow patterns, timing, and volume. For example, land development affects the natural rainfall-runoff relation by changing the natural infiltration characteristics of the watershed. This often leads to increased surface runoff and streamflow, as well as increases in the rate at which runoff moves through the watershed. For this assessment, population density was used as a surrogate measure of anthropogenic activity upon watersheds in the UCRB. The 2000 population density (Hitt, 2003) was computed for unregulated and

Table 4. Six lithologic classifications in the Upper Colorado River Basin (Kenney and others, 2009).

\begin{tabular}{lc}
\hline \multicolumn{1}{c}{ Lithologic classifications } & $\begin{array}{c}\text { Total area } \\
\text { (square miles) }\end{array}$ \\
\hline Sedimentary, clastic, Mesozoic & 50,200 \\
Sedimentary, clastic (continental), Tertiary & 38,000 \\
Igneous and metamorphic & 9,660 \\
Sedimenatry, mixed (continental and marine) & 5,910 \\
Sedimentary, carbonate (marine) & 4,240 \\
Sedimentary, basin-fill (continental) & 8.91 \\
\hline
\end{tabular}

regulated UCRB watersheds and watersheds instrumented with USGS streamgages (figs. 41 and 42).

The UCRB is largely a rural region that has a population density of 1.8 people $/ \mathrm{mi}^{2}$. Much of the land development is associated with agriculture rather than urban or suburban development. The population density of unregulated watersheds is skewed toward low population densities. The USGS streamgage network and the active USGS gages slightly underrepresent UCRB unregulated watersheds for population densities less then 15 people $/ \mathrm{mi}^{2}$. Unregulated UCRB watersheds where population density is greater than 15 people $/ \mathrm{mi}^{2}$ are not represented well in the USGS streamgage network. In addition, there are no regulated USGS streamgages in watersheds with populations greater than 10 people $/ \mathrm{mi}^{2}$. This shows that the USGS streamgage network underrepresents high population density watersheds relative to the UCRB. Overall, for regulated watersheds, the criteria of 20 percent coverage for the entire USGS network and 10 percent for the active USGS network are rarely met for population density.

\section{Road Density}

The density of roads in a watershed also can provide an indication of the amount of anthropogenic activity in a watershed. Similar to development, roads have a direct influence on the runoff characteristics of a watershed. Roads are often constructed of impervious materials such as concrete or asphalt, or can be simply bare ground. Surface runoff from all road types is generally greater than natural conditions because of the impervious nature of the material, the compact condition of the road bed, and (or) the lack of vegetation compared with the surrounding landscape. The density of all road types, in $\mathrm{mi} / \mathrm{mi}^{2}$, was computed from mapped roads (U.S. Geological Survey, 2010) for unregulated and regulated watersheds in the UCRB as well as those instrumented with USGS streamgages (figs. 43 and 44). The average road density for the entire UCRB is $1.6 \mathrm{mi} / \mathrm{mi}^{2}$. Computed road densities can be considered a minimum road density because the mapped roads' dataset often does not include many smaller and minor, dirt and gravel roads. This is particularly true in areas of recent energy development and in areas where recreational roads have grown and propagated (Buto and others, 2010).

The UCRB is a rural region, thus, road densities are low, ranging from 0 to about $9 \mathrm{mi} / \mathrm{mi}^{2}$. For unregulated watersheds, the USGS streamgage network and the active USGS gages are representative of UCRB watersheds having road densities less than $2 \mathrm{mi} / \mathrm{mi}^{2}$, but the USGS streamgage network underrepresents UCRB watersheds with road densities greater than 2 $\mathrm{mi} / \mathrm{mi}^{2}$. Many unregulated watersheds in the UCRB have road densities greater than $3 \mathrm{mi} / \mathrm{mi}^{2}$, yet there are only 19 gages, 3 of which are active, in watersheds where road densities exceed $3 \mathrm{mi} / \mathrm{mi}^{2}$. Regulated watersheds where roads densities are less than $1.5 \mathrm{mi} / \mathrm{mi}^{2}$ are represented well by the USGS streamgage network, including the active gages, but watersheds where road densities are greater than $1.5 \mathrm{mi} / \mathrm{mi}^{2}$ are underrepresented by the USGS streamgage network. 


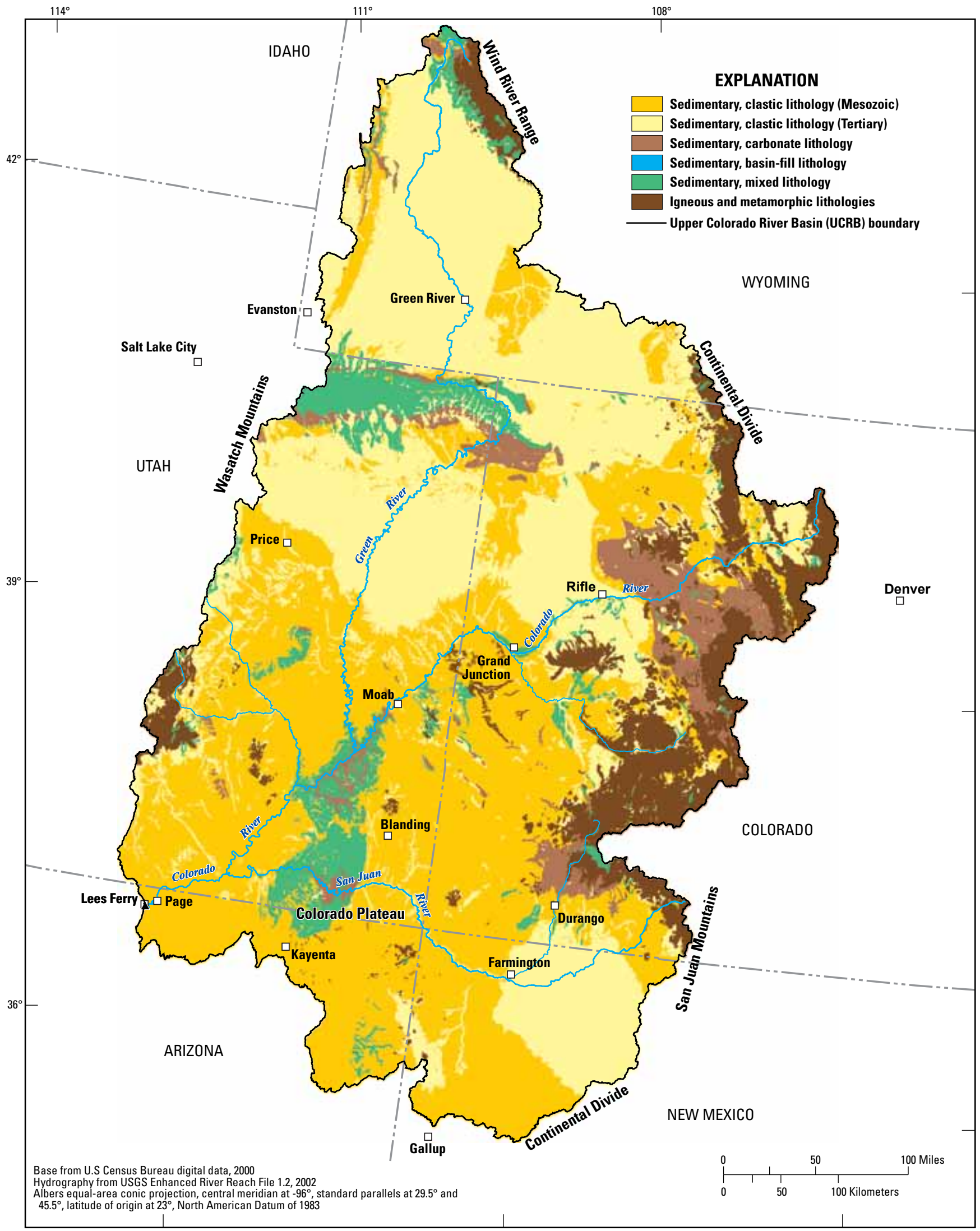

Figure 30. Distribution of the six lithologic classifications in the Upper Colorado River Basin. 


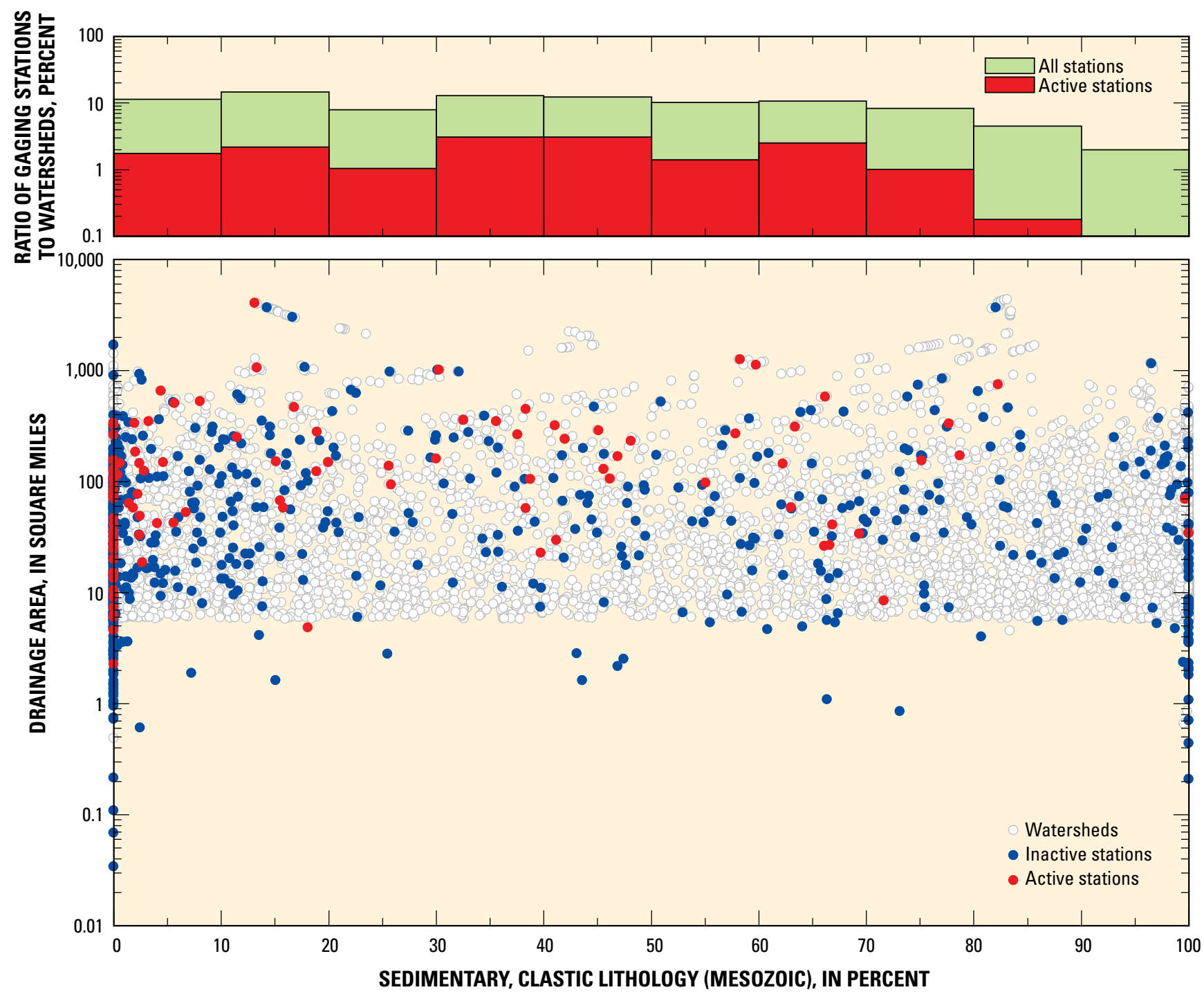

Figure 31. Percentage of drainage basin area having sedimentary, clastic lithology (Mesozoic) for watersheds and U.S. Geological Survey streamgages in the Upper Colorado River Basin that are unaffected by reservoir regulation. 


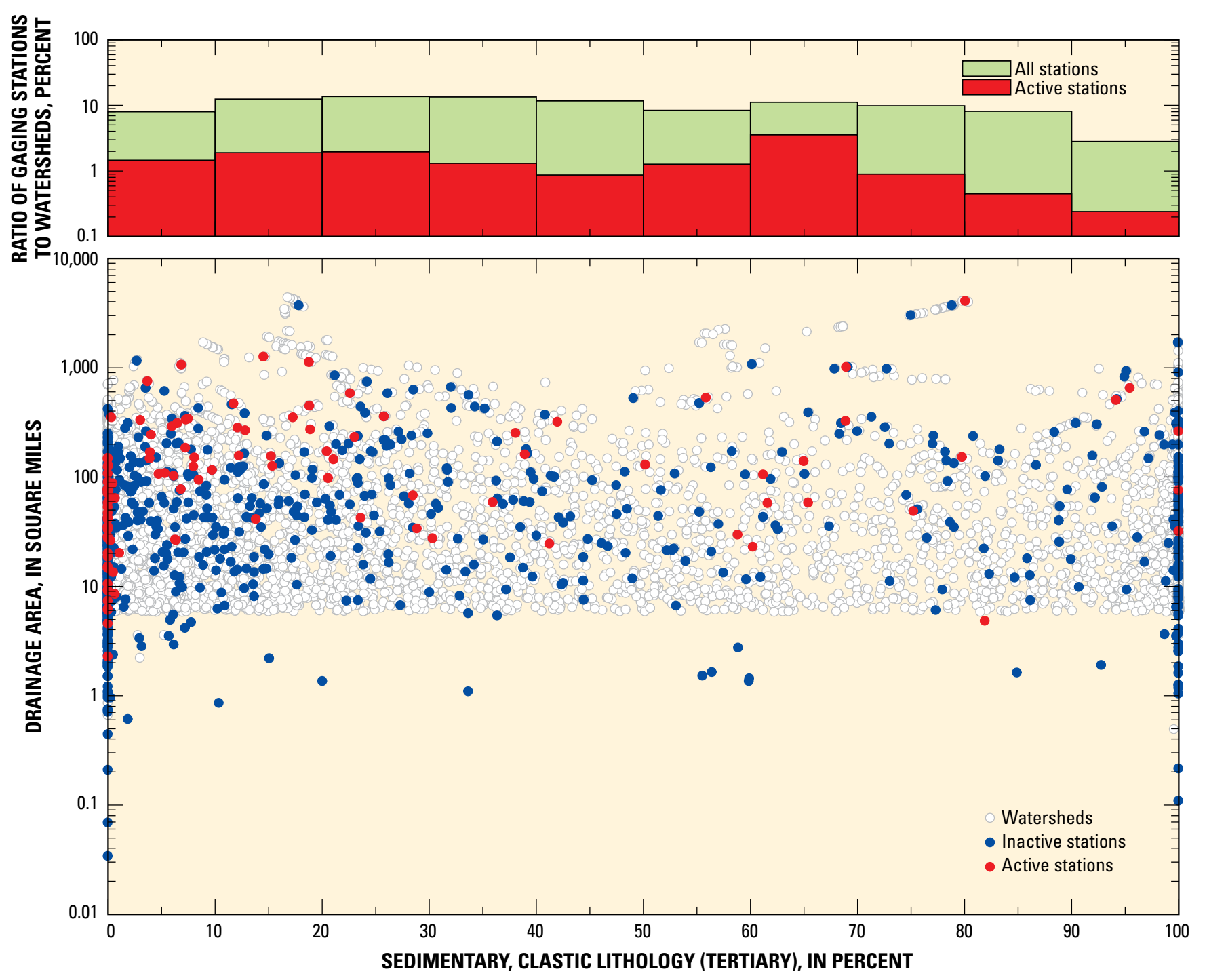

Figure 32. Percentage of drainage basin area having sedimentary, clastic (continental) lithology (Tertiary) for watersheds and U.S. Geological Survey streamgages in the Upper Colorado River Basin that are unaffected by reservoir regulation. 


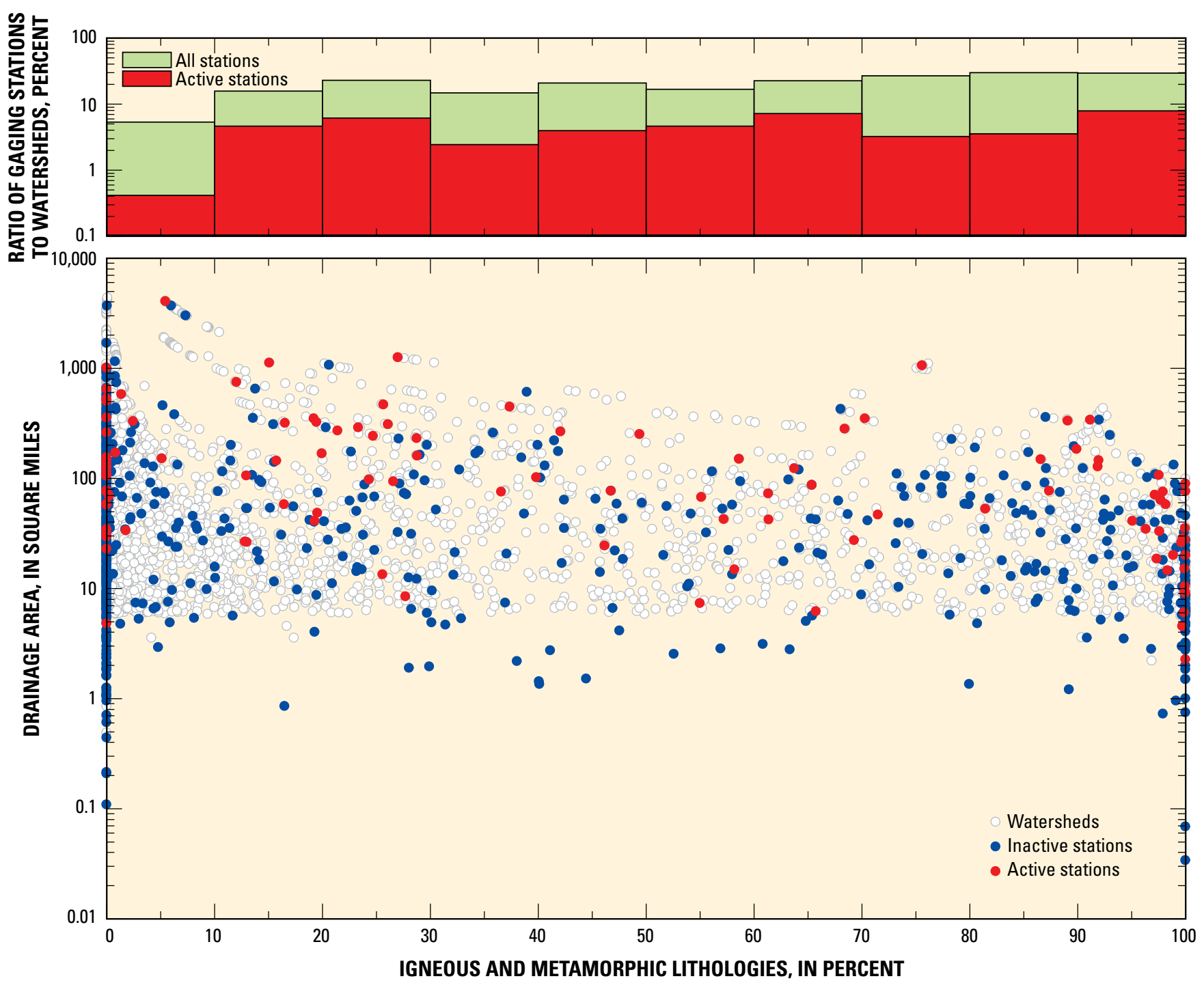

Figure 33. Percentage of area having igneous or metamorphic lithologies for watersheds and U.S. Geological Survey streamgages in the Upper Colorado River Basin that are unaffected by reservoir regulation. 


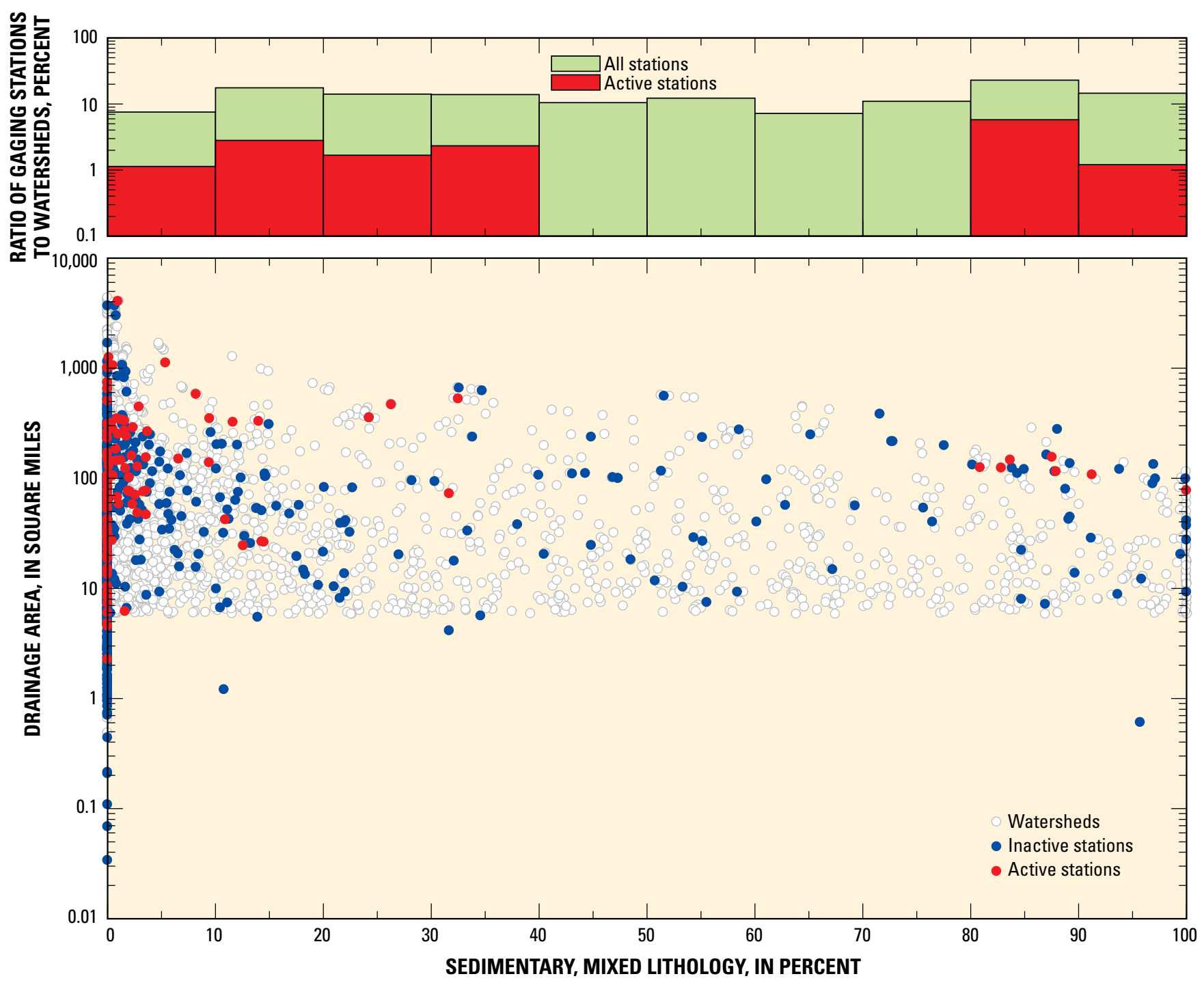

Figure 34. Percentage of drainage basin area having sedimentary, mixed (continental and marine) lithology for watersheds and U.S. Geological Survey streamgages in the Upper Colorado River Basin that are affected by reservoir regulation. 


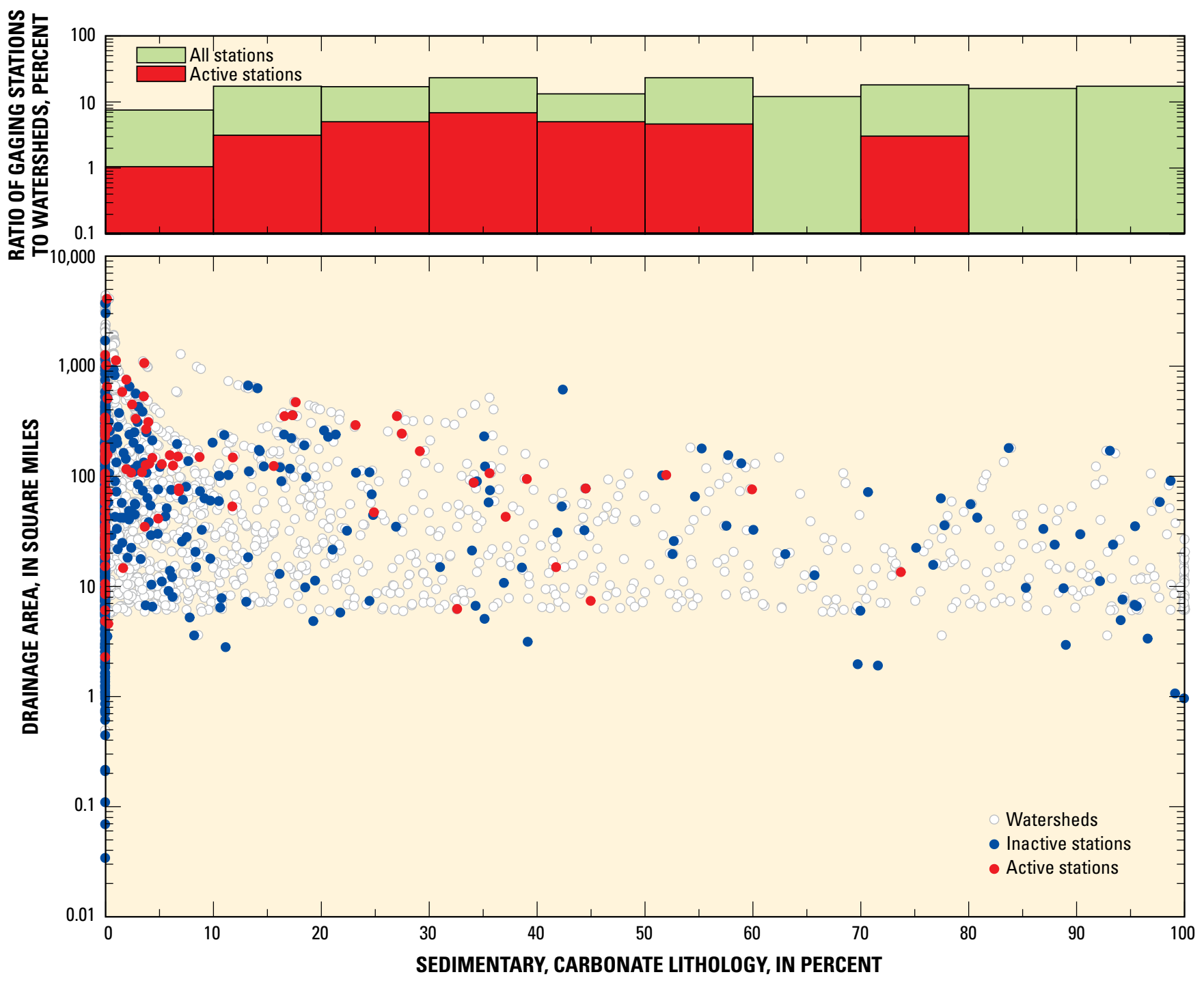

Figure 35. Percentage of drainage basin area having sedimentary, carbonate (marine) lithology for watersheds and U.S. Geological Survey streamgages in the Upper Colorado River Basin that are unaffected by reservoir regulation. 


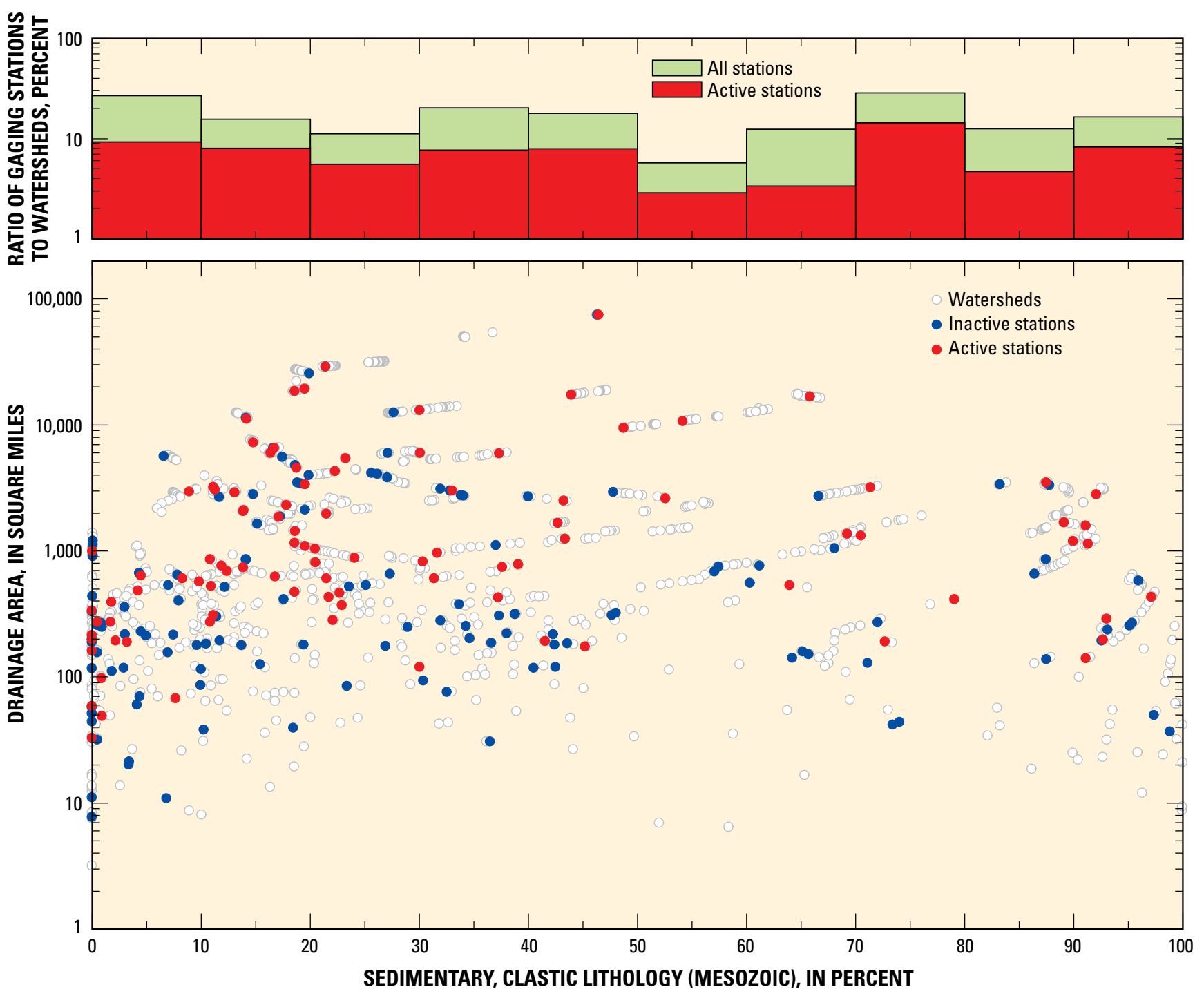

Figure 36. Percentage of drainage basin area having sedimentary, clastic lithology (Mesozoic) for watersheds and U.S. Geological Survey streamgages in the Upper Colorado River Basin that are affected by reservoir regulation. 


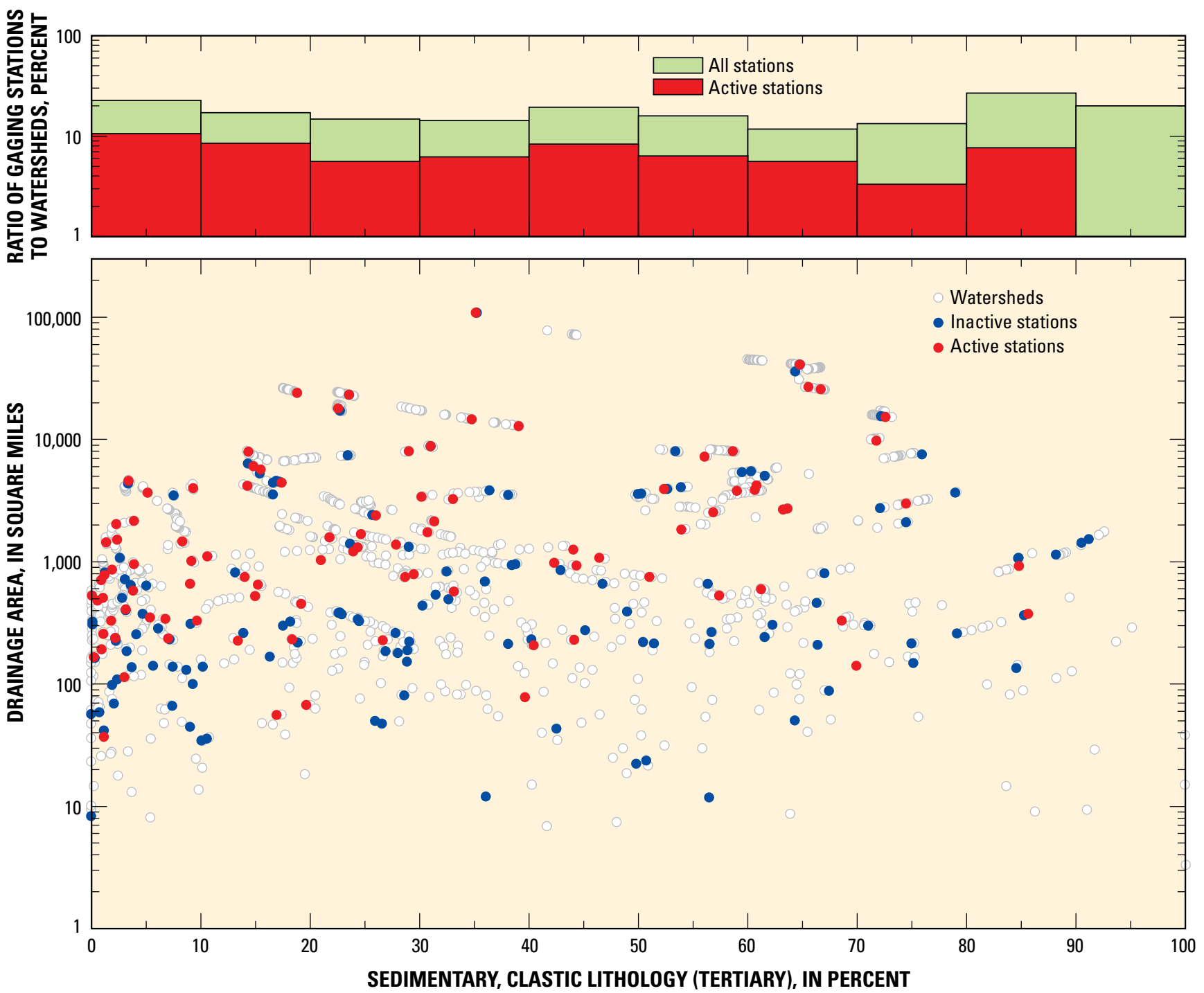

Figure 37. Percentage of drainage basin area having sedimentary, clastic (continental) lithology (Tertiary) for watersheds and U.S. Geological Survey streamgages in the Upper Colorado River Basin that are affected by reservoir regulation. 


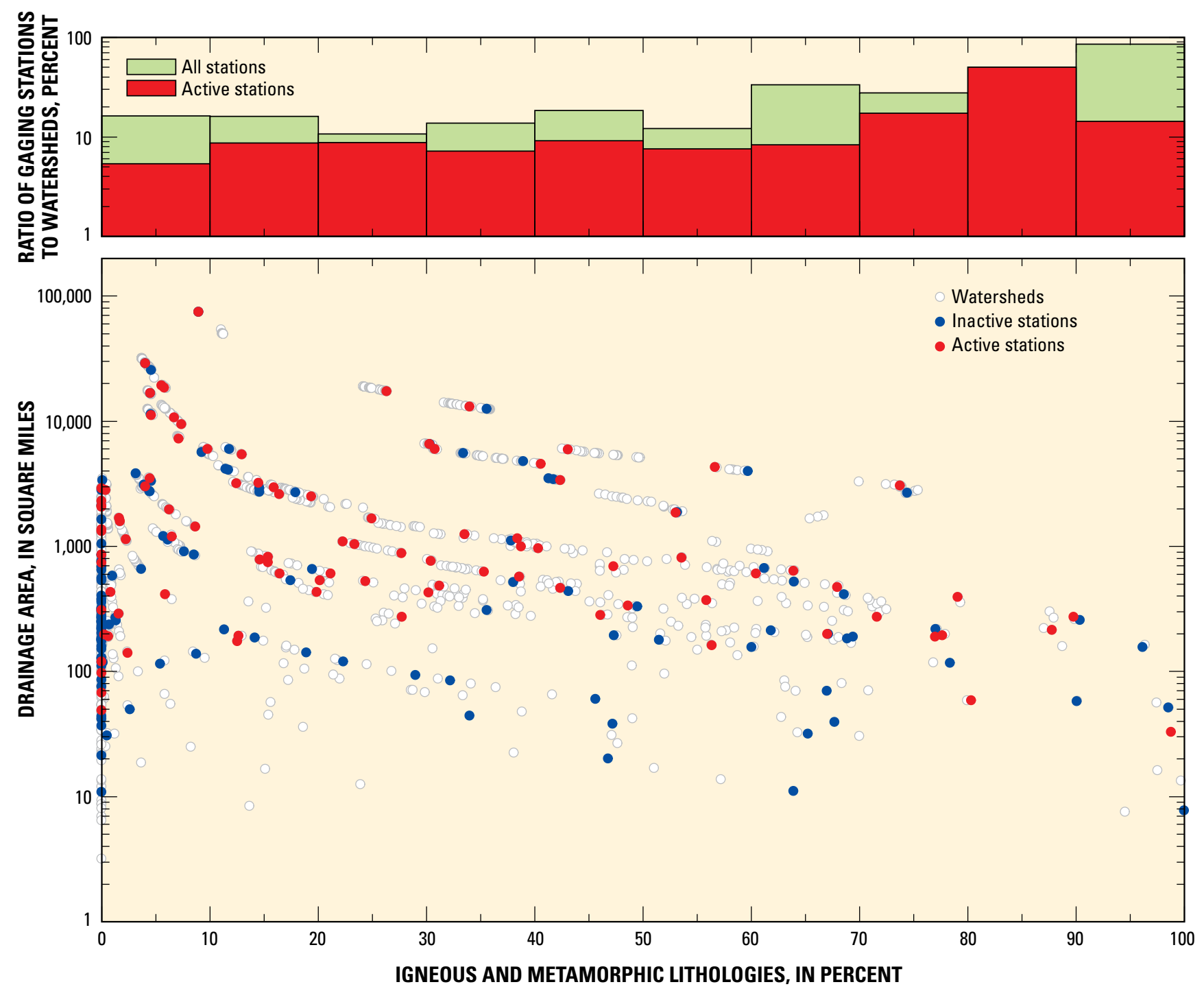

Figure 38. Percentage of drainage basin area having igneous or metamorphic lithology for watersheds and U.S. Geological Survey streamgages in the Upper Colorado River Basin that are affected by reservoir regulation. 


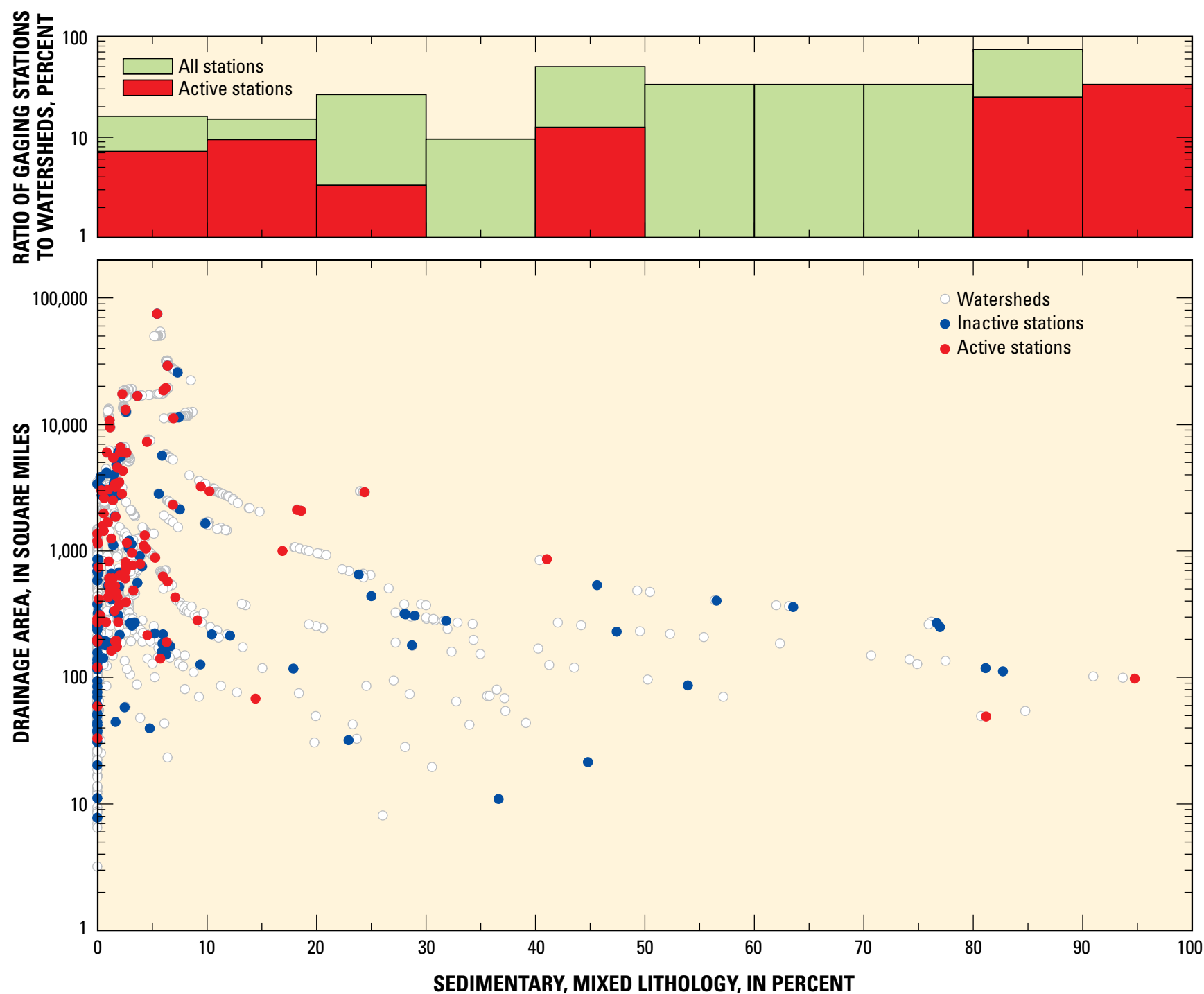

Figure 39. Percentage of drainage basin area having sedimentary, mixed (continental and marine) lithology for watersheds and U.S. Geological Survey streamgages in the Upper Colorado River Basin that are affected by reservoir regulation. 

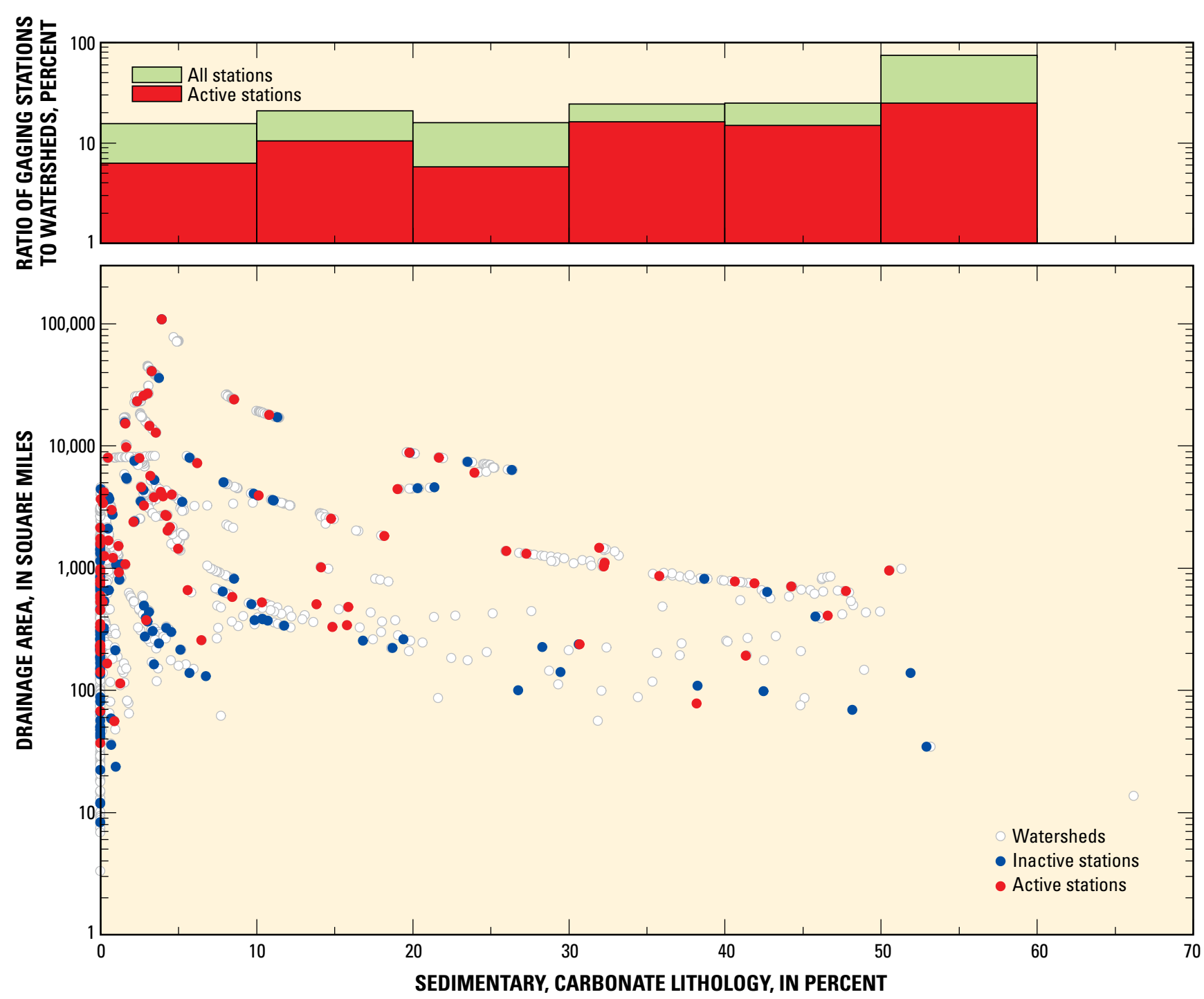

Figure 40. Percentage of drainage basin area having sedimentary, carbonate (marine) lithology for watersheds and U.S. Geological Survey streamgages in the Upper Colorado River Basin that are affected by reservoir regulation. 


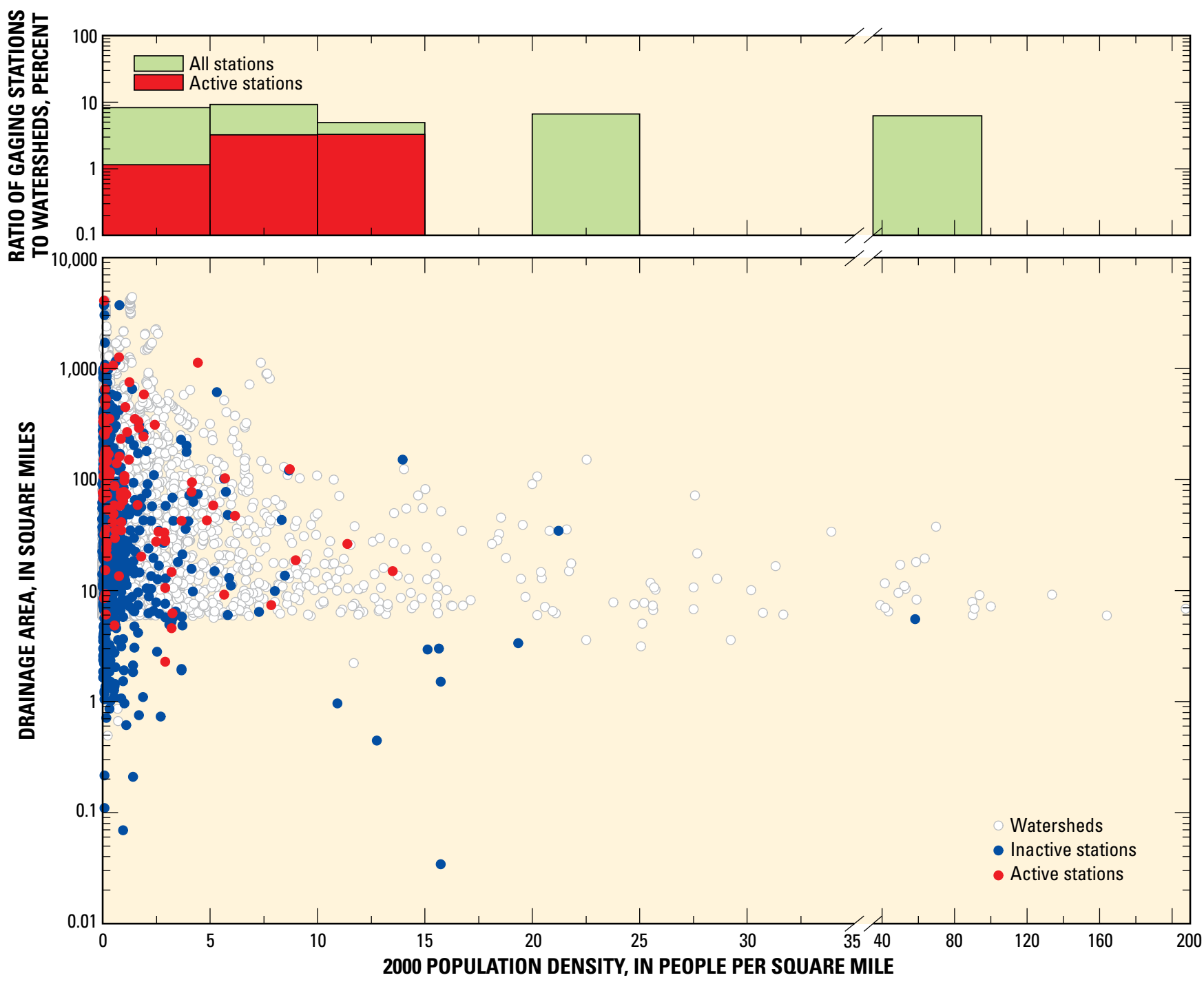

Figure 41. Population density for watersheds and U.S. Geological Survey streamgage locations in the Upper Colorado River Basin that are unaffected by reservoir regulation. 


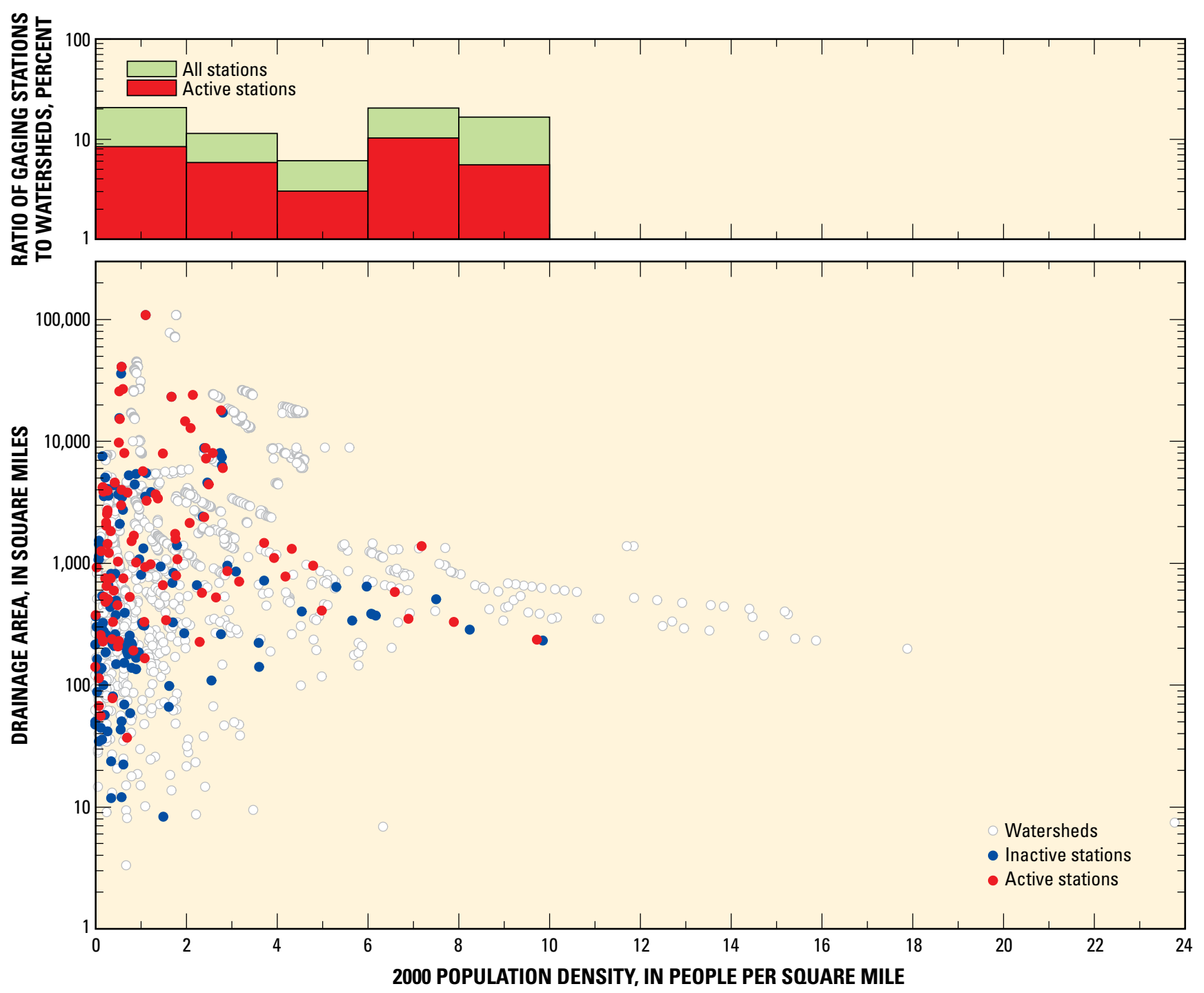

Figure 42. Population density for watersheds and U.S. Geological Survey streamgage locations in the Upper Colorado River Basin that are affected by reservoir regulation. 


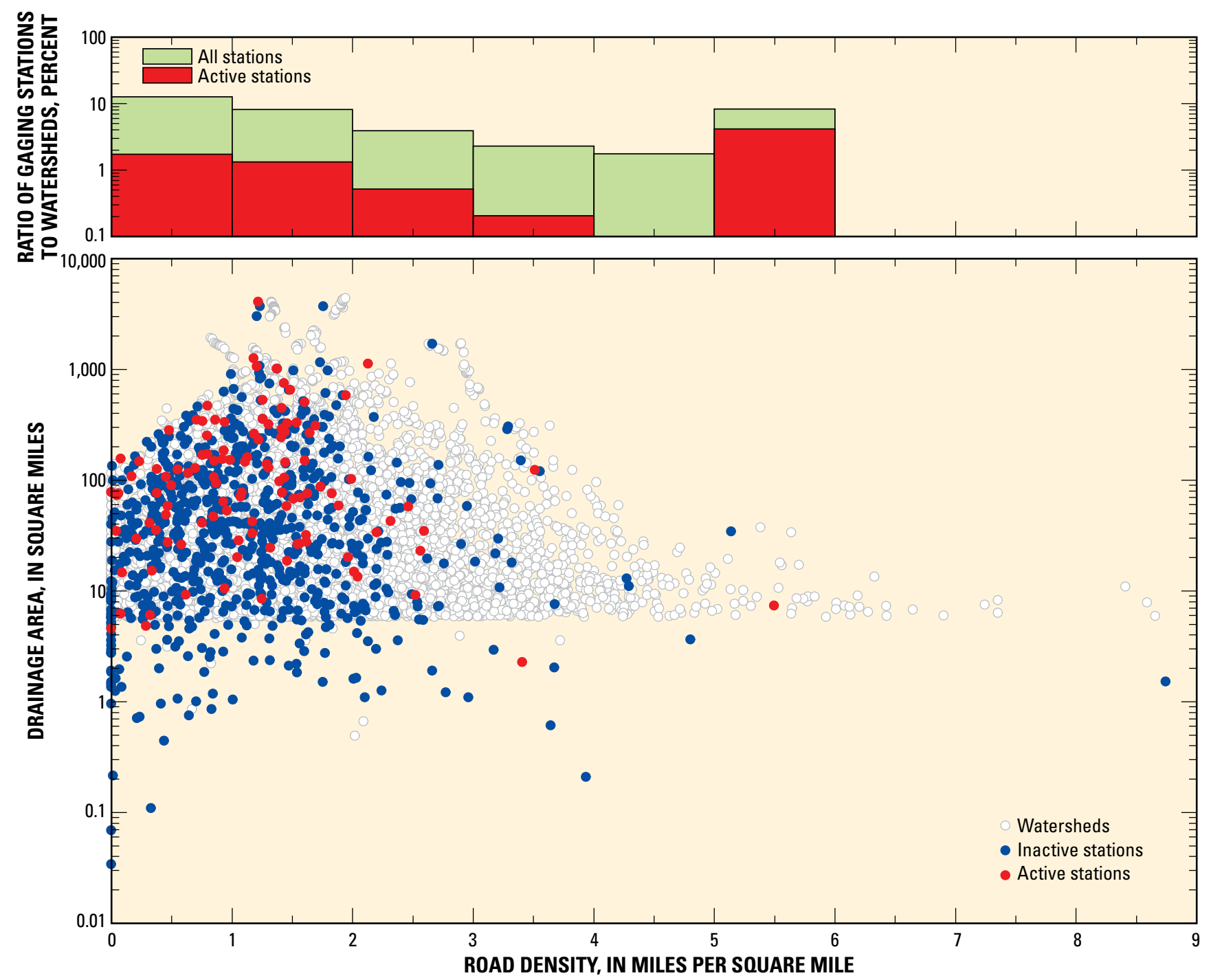

Figure 43. Road density for watersheds and U.S. Geological Survey streamgage locations in the Upper Colorado River Basin that are unaffected by reservoir regulation. 


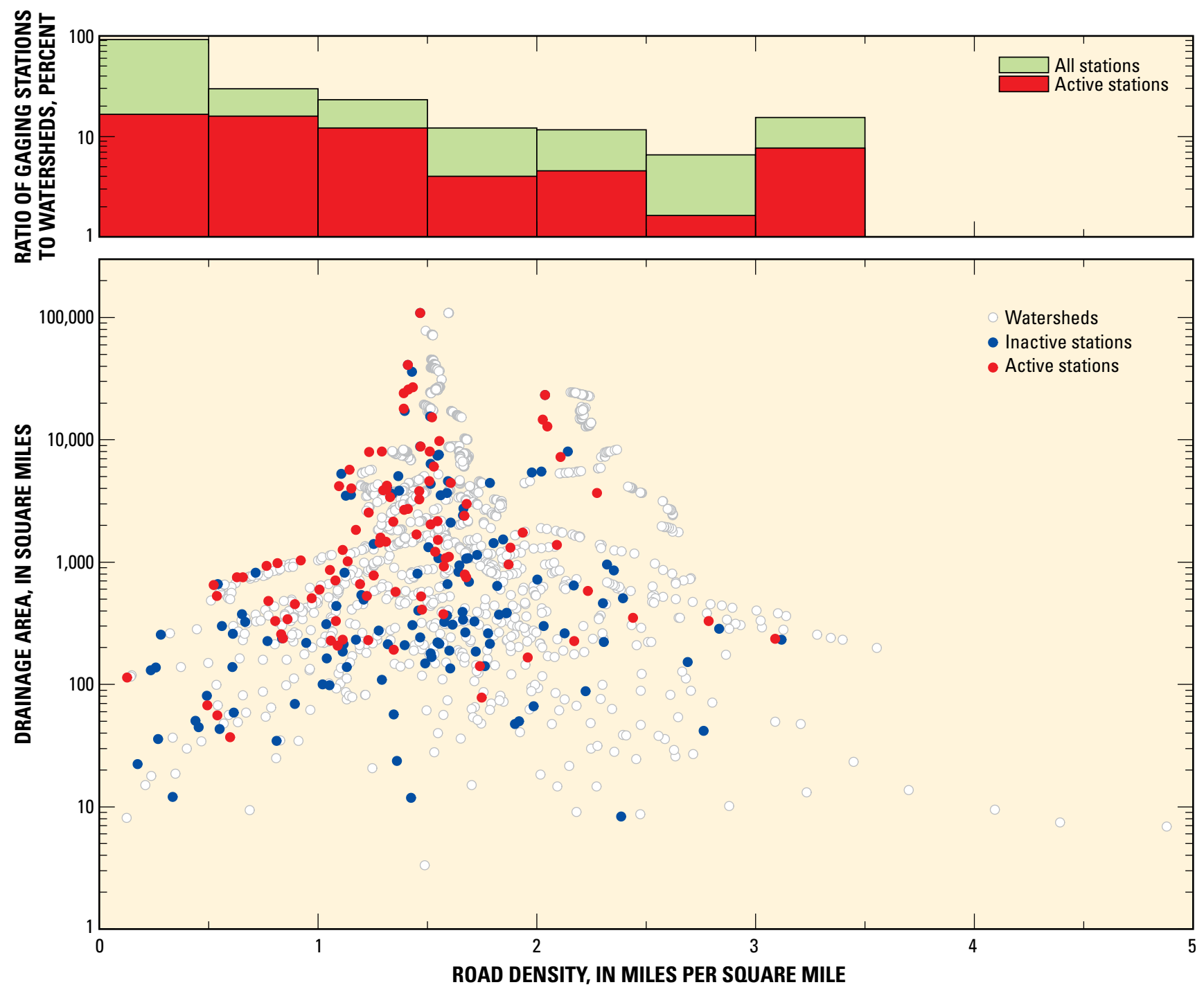

Figure 44. Road density for watersheds and U.S. Geological Survey streamgage locations in the Upper Colorado River Basin that are affected by reservoir regulation.

\section{Summary}

The U.S. Geological Survey (USGS) has been gaging streamflow in the Upper Colorado River Basin (UCRB) since 1894. Since then, the USGS has operated 1,053 streamgages, of which 223 are active as of 2010 . To assess how the USGS streamgage network represents the landscapes in the UCRB, 17 watershed characteristics were computed for each of the watersheds associated with these streamgages. The 17 watershed characteristics include physiographic parameters, land cover types, lithology, and parameters that describe anthropogenic influence. A set of 10,338 watersheds in the UCRB was constructed from a previously developed stream-reach network and the same 17 watershed characteristics were computed for each watershed. This set of watersheds was used to assess how well the streamgage network, both historically and currently, represents the landscapes in the UCRB. Computed watershed characteristics for UCRB watersheds and each watershed instrumented with a USGS streamgage were plotted together to graphically identify watersheds, in terms of drainage area and the watershed characteristics, that are represented well by the USGS streamgage network and watersheds that are not represented well by the network. Active streamgages were identified in these plots to assess how the active network compares with the inactive network as well as with the watersheds in the basin. In many watersheds on the Colorado Plateau, much of the streamflow is ephemeral or intermittent. These types of watersheds are rarely monitored with streamgages, which creates an inherent bias in the USGS streamgage network toward watersheds that have perennial streamflow.

Watersheds were divided into those that are unaffected by upstream reservoir regulation and those affected by upstream reservoir regulation. In most cases, the streamgage network adequately represented the range of basin characteristics considered in this report for the unregulated watersheds of the UCRB, although the active USGS streamgage network tended 
to underrepresent most basin characteristics in unregulated watersheds. In regulated watersheds, the streamgage network, including the active network, generally represented the range of most basin characteristics in the watersheds of the UCRB.

\section{References Cited}

Buto, S.G., Kenney, T.A., and Gerner, S.J., 2010, Land disturbance associated with oil and gas development and effects of development-related land disturbance on dissolved-solids loads in streams in the Upper Colorado River Basin, 1991, 2007, and 2025: U.S. Geological Survey Scientific Investigations Report 2010-5064, 56 p. Available at http://pubs. usgs.gov/sir/2010/5064/.

Corbett, D.M., and others, 1943, Stream-gaging procedure; a manual describing methods and practices of the Geological Survey: U.S. Geological Survey Water-Supply Paper 888, $245 \mathrm{p}$.

Hitt, K.J., 2003, 2000 population density by block group for the conterminous United States: U.S. Geological Survey raster digital data, accessed August 2009 at http:/water. usgs.gov/GIS/metadata/usgswrd/XML/uspopd00x10g.xml.

Homer, C., Huang, C., Yang, L., Wylie B., and Coan, M., 2004, Development of a 2001 national land cover database for the United States: Photogrammetric Engineering and Remote Sensing, v. 70, no. 7, p. 829-840, accessed April 2010 at http://www.mrlc.gov/publications.php.
Kenney, T.A., Gerner, S.J., Buto, S.G., and Spangler, L.E., 2009, Spatially referenced statistical assessment of dissolved-solids load sources and transport in streams of the Upper Colorado River Basin: U.S. Geological Survey Scientific Investigations Report 2009-5007, 50 p. Available at http://pubs.usgs.gov/sir/2009/5007.

PRISM Group, Oregon State University, 2007, Digital climate data, accessed August 2009 at http://www.ocs.oregonstate. edu/prism/index.phtml.

Ruddy, B.C. and Hitt, K.J., 1990, Summary of selected characteristics of large reservoirs: U.S. Geological Survey Open-File Report 90-163, accessed March 2010 at http:// water.usgs.gov/lookup/getspatial?reservoir.

U.S. Geological Survey, 1999, The National Hydrography Dataset: U.S. Geological Survey Fact Sheet 109-99, accessed September 2006 at http://erg.usgs.gov/isb/pubs/ factsheets/fs 10699.html.

U.S. Geological Survey, 2010, The National Map: Transportation, vector digital data, accessed July 2010 at http://nationalmap.gov/transport.html. 
Appendix 1. U.S. Geological Survey streamflow-gaging stations in the Upper Colorado River Basin. 
Appendix 1-1. Watershed characteristics for the U.S. Geological Survey streamgage network in the Upper Colorado River Basin.

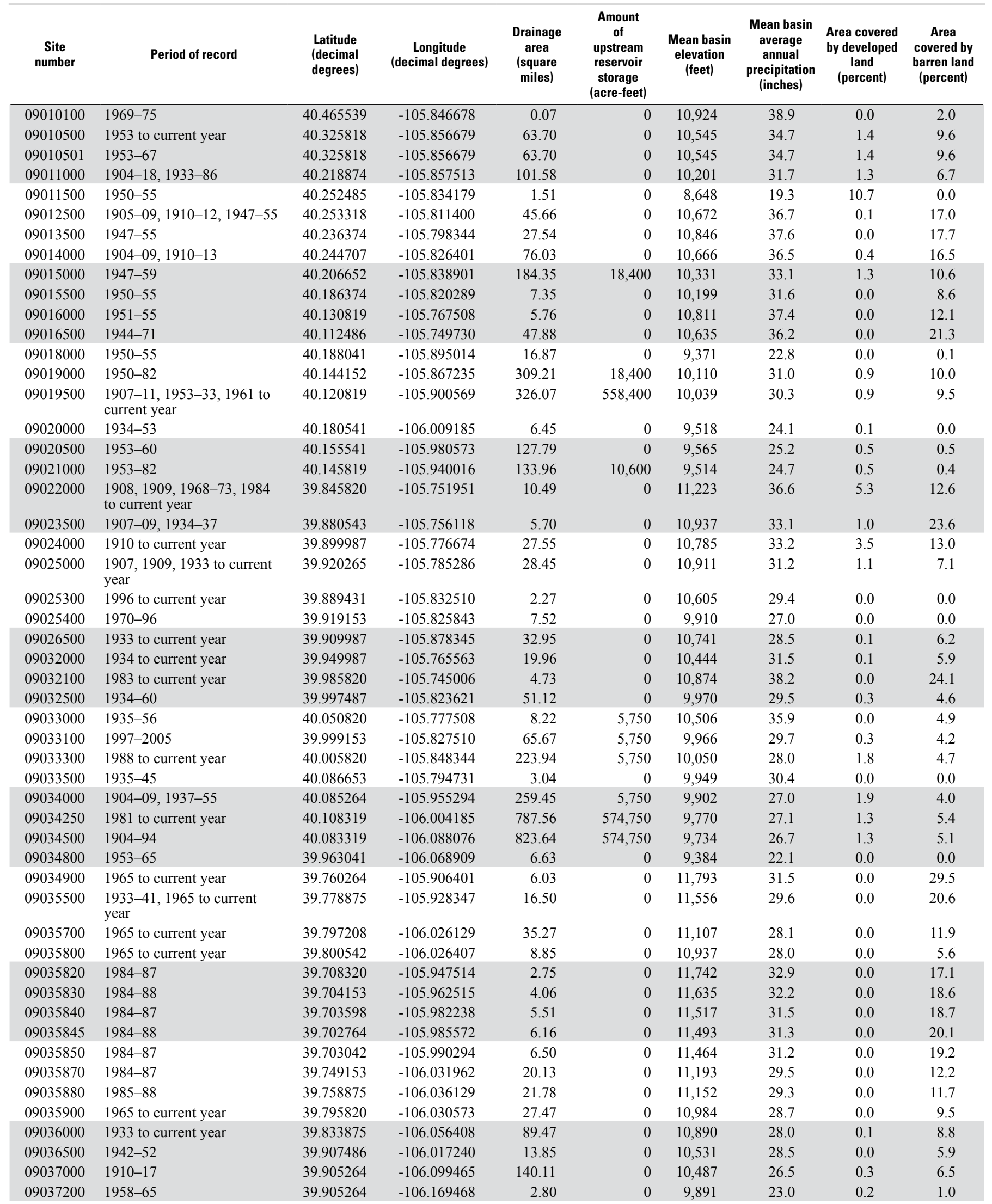




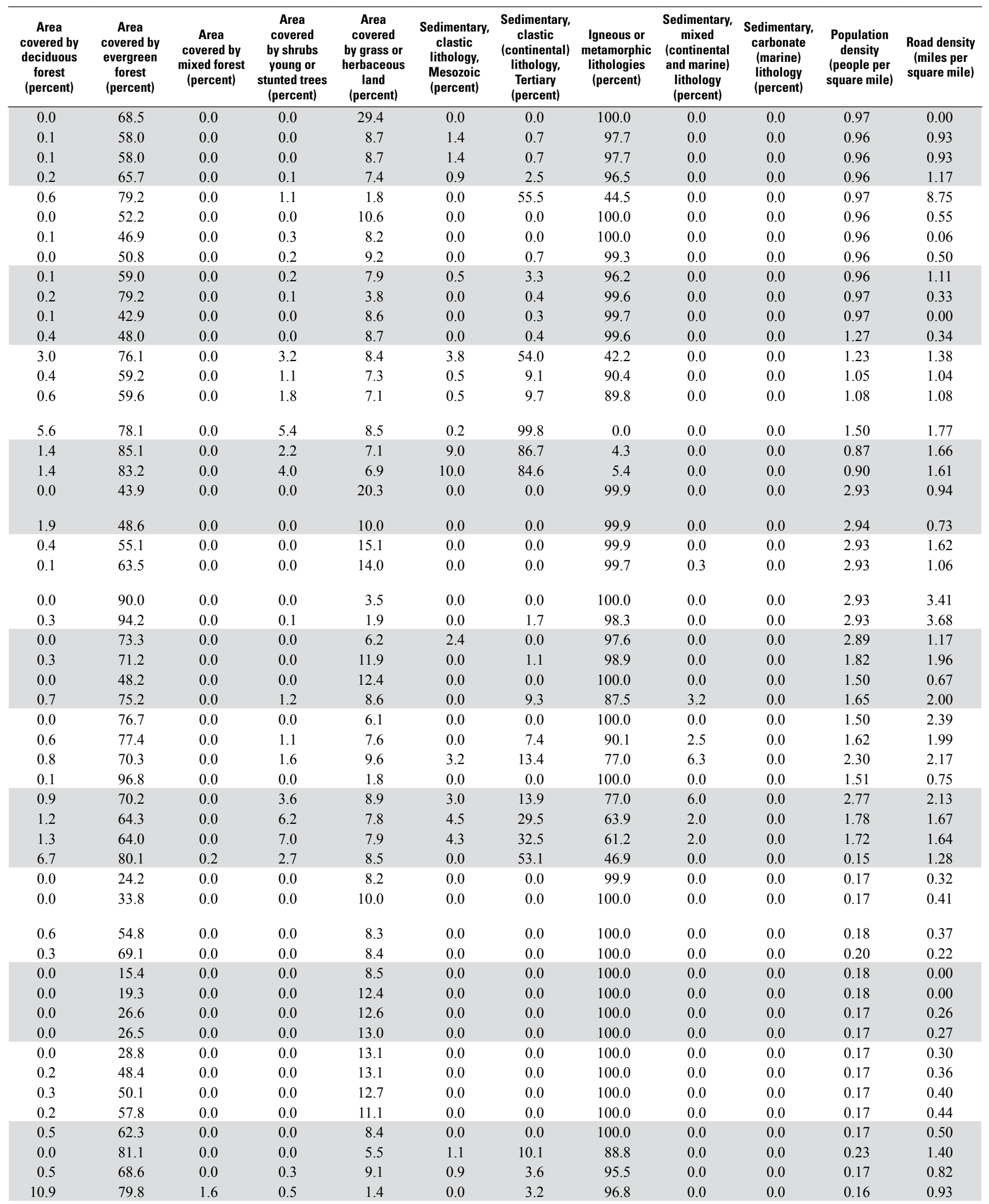


Appendix 1-1. Watershed characteristics for the U.S. Geological Survey streamgage network in the Upper Colorado River Basin.-Continued

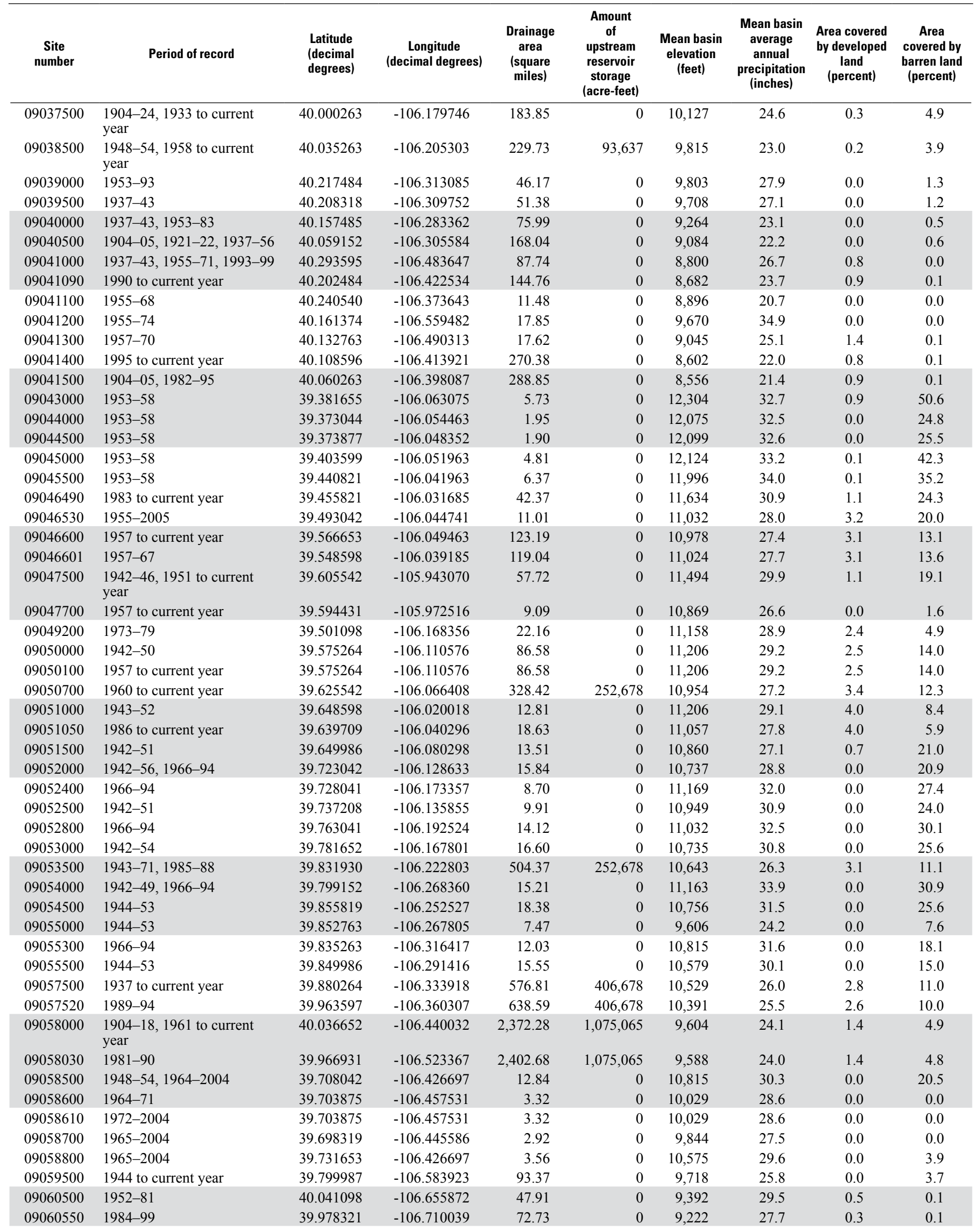




\begin{tabular}{|c|c|c|c|c|c|c|c|c|c|c|c|}
\hline $\begin{array}{c}\text { Area } \\
\text { covered by } \\
\text { deciduous } \\
\text { forest } \\
\text { (percent) }\end{array}$ & $\begin{array}{c}\text { Area } \\
\text { covered by } \\
\text { evergreen } \\
\text { forest } \\
\text { (percent) }\end{array}$ & $\begin{array}{c}\text { Area } \\
\text { covered by } \\
\text { mixed forest } \\
\text { (percent) }\end{array}$ & $\begin{array}{c}\text { Area } \\
\text { covered } \\
\text { by shrubs } \\
\text { young or } \\
\text { stunted trees } \\
\text { (percent) }\end{array}$ & $\begin{array}{c}\text { Area } \\
\text { covered } \\
\text { by grass or } \\
\text { herbaceous } \\
\text { land } \\
\text { (percent) }\end{array}$ & $\begin{array}{l}\text { Sedimentary, } \\
\text { clastic } \\
\text { lithology, } \\
\text { Mesozoic } \\
\text { (percent) }\end{array}$ & $\begin{array}{l}\text { Sedimentary, } \\
\text { clastic } \\
\text { (continental) } \\
\text { lithology, } \\
\text { Tertiary } \\
\text { (percent) }\end{array}$ & $\begin{array}{l}\text { Igneous or } \\
\text { metamorphic } \\
\text { lithologies } \\
\text { (percent) }\end{array}$ & $\begin{array}{c}\text { Sedimentary, } \\
\text { mixed } \\
\text { (continental } \\
\text { and marine) } \\
\text { lithology } \\
\text { (percent) }\end{array}$ & $\begin{array}{c}\text { Sedimentary, } \\
\text { carbonate } \\
\text { (marine) } \\
\text { lithology } \\
\text { (percent) }\end{array}$ & $\begin{array}{l}\text { Population } \\
\text { density } \\
\text { (people per } \\
\text { square mile) }\end{array}$ & $\begin{array}{c}\text { Road density } \\
\text { (miles per } \\
\text { square mile) }\end{array}$ \\
\hline 1.7 & 65.3 & 0.1 & 5.7 & 8.2 & 2.0 & 7.2 & 89.9 & 0.8 & 0.0 & 0.17 & 0.93 \\
\hline 2.6 & 58.9 & 0.2 & 13.0 & 7.3 & 2.2 & 18.4 & 77.7 & 1.7 & 0.0 & 0.17 & 1.12 \\
\hline 3.2 & 75.6 & 0.2 & 7.8 & 8.6 & 0.0 & 14.9 & 85.1 & 0.0 & 0.0 & 0.15 & 0.84 \\
\hline 2.8 & 79.5 & 0.1 & 6.8 & 7.8 & 0.0 & 89.6 & 10.4 & 0.0 & 0.0 & 0.15 & 0.37 \\
\hline 2.4 & 60.4 & 0.1 & 20.6 & 8.0 & 0.7 & 63.0 & 34.2 & 2.1 & 0.0 & 0.15 & 0.83 \\
\hline 13.2 & 34.6 & 0.3 & 23.8 & 17.3 & 52.6 & 23.4 & 23.9 & 0.0 & 0.0 & 0.19 & 1.46 \\
\hline 12.5 & 26.3 & 0.3 & 35.9 & 15.5 & 62.3 & 21.1 & 15.7 & 0.8 & 0.0 & 0.17 & 1.44 \\
\hline 13.3 & 22.9 & 0.1 & 42.7 & 17.7 & 24.8 & 59.6 & 15.5 & 0.0 & 0.0 & 0.15 & 0.96 \\
\hline 0.1 & 11.0 & 0.0 & 0.0 & 21.8 & 0.0 & 0.0 & 78.2 & 0.0 & 21.8 & 3.72 & 1.78 \\
\hline 0.0 & 25.8 & 0.0 & 0.0 & 46.8 & 0.0 & 0.0 & 29.9 & 0.0 & 69.7 & 3.69 & 0.07 \\
\hline 0.0 & 23.8 & 0.0 & 0.0 & 48.1 & 0.0 & 0.0 & 28.0 & 0.0 & 71.6 & 3.69 & 0.00 \\
\hline 1.6 & 18.0 & 0.0 & 0.0 & 23.3 & 0.0 & 0.0 & 80.7 & 0.0 & 19.3 & 3.73 & 1.34 \\
\hline 0.2 & 29.4 & 0.0 & 0.0 & 23.6 & 0.0 & 0.0 & 89.3 & 0.0 & 10.7 & 7.30 & 2.02 \\
\hline 1.1 & 40.6 & 0.0 & 0.0 & 24.4 & 5.6 & 0.0 & 57.2 & 0.0 & 37.1 & 4.87 & 2.32 \\
\hline 2.6 & 59.9 & 0.0 & 0.0 & 11.3 & 39.8 & 0.0 & 54.0 & 0.8 & 5.2 & 5.98 & 4.29 \\
\hline 2.4 & 56.3 & 0.1 & 0.1 & 19.7 & 18.9 & 0.0 & 63.8 & 1.6 & 15.6 & 8.73 & 3.51 \\
\hline 2.2 & 55.8 & 0.1 & 0.0 & 20.0 & 17.9 & 0.0 & 64.2 & 1.7 & 16.2 & 8.70 & 3.55 \\
\hline 1.7 & 39.4 & 0.0 & 0.0 & 31.4 & 1.8 & 0.0 & 98.2 & 0.0 & 0.0 & 5.17 & 1.46 \\
\hline 0.3 & 81.3 & 0.1 & 0.0 & 15.9 & 0.0 & 0.0 & 100.0 & 0.0 & 0.0 & 5.68 & 2.52 \\
\hline 0.9 & 45.2 & 0.0 & 0.0 & 11.8 & 1.5 & 0.0 & 98.5 & 0.0 & 0.0 & 0.25 & 0.20 \\
\hline 1.4 & 47.4 & 0.0 & 0.6 & 13.3 & 1.5 & 0.0 & 98.5 & 0.0 & 0.0 & 0.24 & 0.59 \\
\hline 3.4 & 29.5 & 0.1 & 0.0 & 18.5 & 1.8 & 12.1 & 86.0 & 0.0 & 0.0 & 0.24 & 0.27 \\
\hline 4.2 & 33.4 & 0.1 & 1.5 & 18.0 & 2.3 & 11.5 & 86.2 & 0.0 & 0.0 & 0.24 & 0.34 \\
\hline 4.2 & 49.2 & 0.5 & 3.8 & 20.4 & 17.6 & 2.8 & 68.6 & 1.3 & 9.7 & 7.51 & 2.40 \\
\hline 2.6 & 28.7 & 0.2 & 0.1 & 9.9 & 0.0 & 5.3 & 94.7 & 0.0 & 0.0 & 0.25 & 0.03 \\
\hline 6.0 & 28.4 & 0.3 & 6.1 & 9.0 & 0.0 & 8.6 & 91.4 & 0.0 & 0.0 & 0.25 & 0.37 \\
\hline 8.4 & 54.4 & 0.7 & 16.6 & 4.9 & 13.9 & 0.0 & 86.1 & 0.0 & 0.0 & 0.23 & 0.57 \\
\hline 2.9 & 44.3 & 0.4 & 0.9 & 7.0 & 4.6 & 6.7 & 88.7 & 0.0 & 0.0 & 0.24 & 0.72 \\
\hline 4.0 & 44.1 & 0.7 & 5.0 & 7.8 & 5.7 & 8.9 & 85.4 & 0.0 & 0.0 & 0.24 & 1.00 \\
\hline 4.3 & 47.0 & 0.5 & 6.5 & 19.0 & 18.6 & 3.8 & 68.0 & 1.1 & 8.5 & 6.60 & 2.24 \\
\hline 4.5 & 46.5 & 0.5 & 9.5 & 17.9 & 23.6 & 3.6 & 64.0 & 1.0 & 7.8 & 5.98 & 2.17 \\
\hline 3.6 & 50.5 & 0.2 & 18.0 & 11.0 & 17.1 & 26.0 & 53.0 & 1.7 & 2.1 & 2.40 & 1.67 \\
\hline 3.6 & 50.4 & 0.2 & 18.3 & 10.9 & 17.3 & 25.7 & 53.2 & 1.6 & 2.2 & 2.37 & 1.66 \\
\hline 10.9 & 35.4 & 0.2 & 0.0 & 15.6 & 0.0 & 0.0 & 83.9 & 0.0 & 16.1 & 5.90 & 0.23 \\
\hline 26.0 & 49.7 & 1.1 & 0.0 & 19.6 & 0.4 & 3.0 & 0.0 & 0.0 & 96.6 & 19.37 & 1.56 \\
\hline 26.0 & 49.7 & 1.1 & 0.0 & 19.6 & 0.4 & 3.0 & 0.0 & 0.0 & 96.6 & 19.37 & 1.56 \\
\hline 12.4 & 65.7 & 1.7 & 0.0 & 14.7 & 0.0 & 6.2 & 4.8 & 0.0 & 89.0 & 15.15 & 3.17 \\
\hline 3.1 & 74.3 & 0.2 & 0.0 & 5.2 & 0.9 & 0.0 & 90.9 & 0.0 & 8.3 & 0.12 & 0.00 \\
\hline 22.6 & 42.9 & 3.4 & 8.7 & 13.5 & 25.8 & 8.5 & 26.6 & 0.0 & 39.1 & 4.19 & 0.87 \\
\hline 2.6 & 74.2 & 0.3 & 0.4 & 15.3 & 10.1 & 3.3 & 84.4 & 0.0 & 2.2 & 0.25 & 1.41 \\
\hline 3.5 & 70.3 & 0.4 & 5.5 & 14.8 & 11.6 & 2.2 & 77.5 & 0.0 & 8.8 & 0.26 & 1.10 \\
\hline
\end{tabular}


Appendix 1-1. Watershed characteristics for the U.S. Geological Survey streamgage network in the Upper Colorado River Basin.-Continued

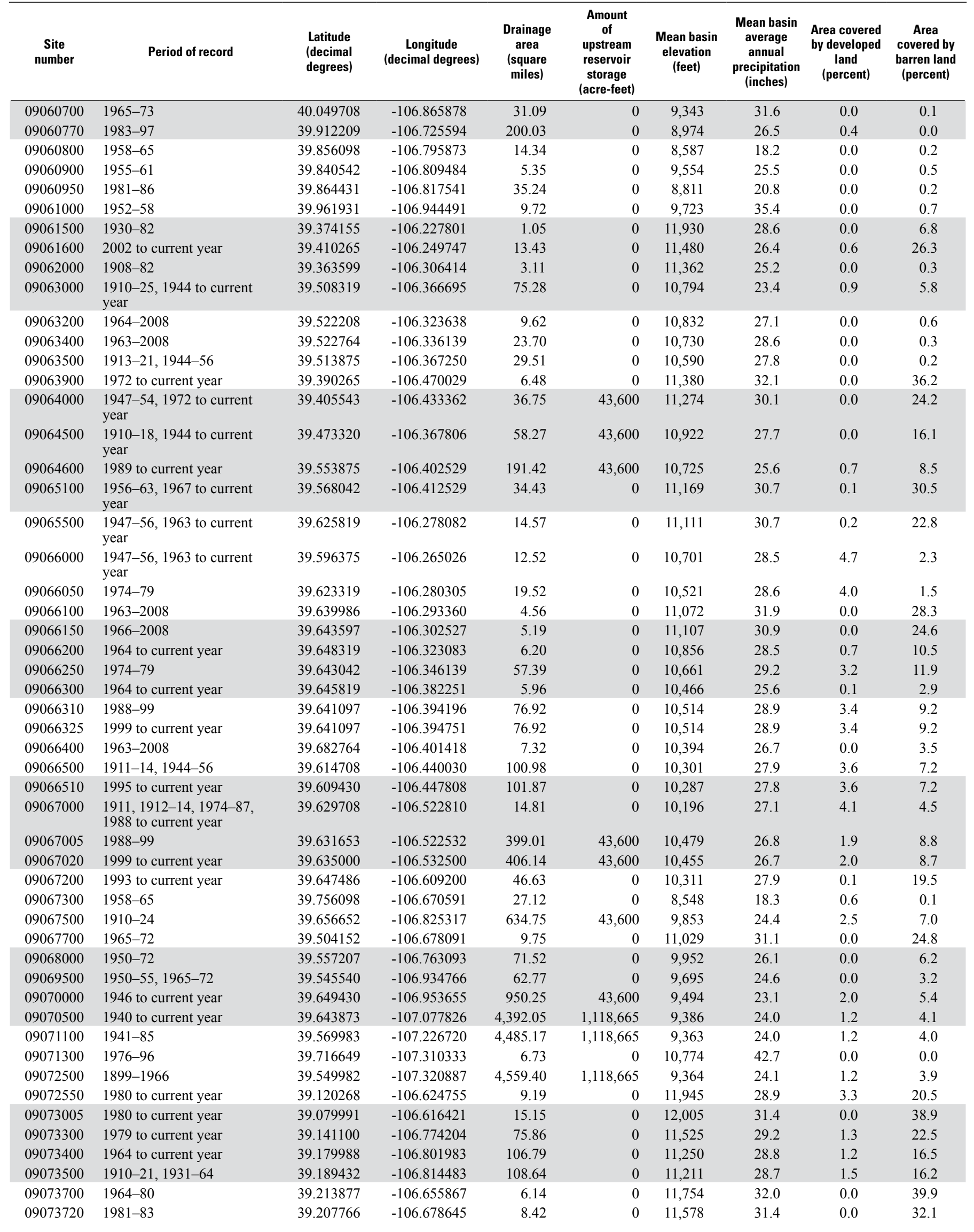




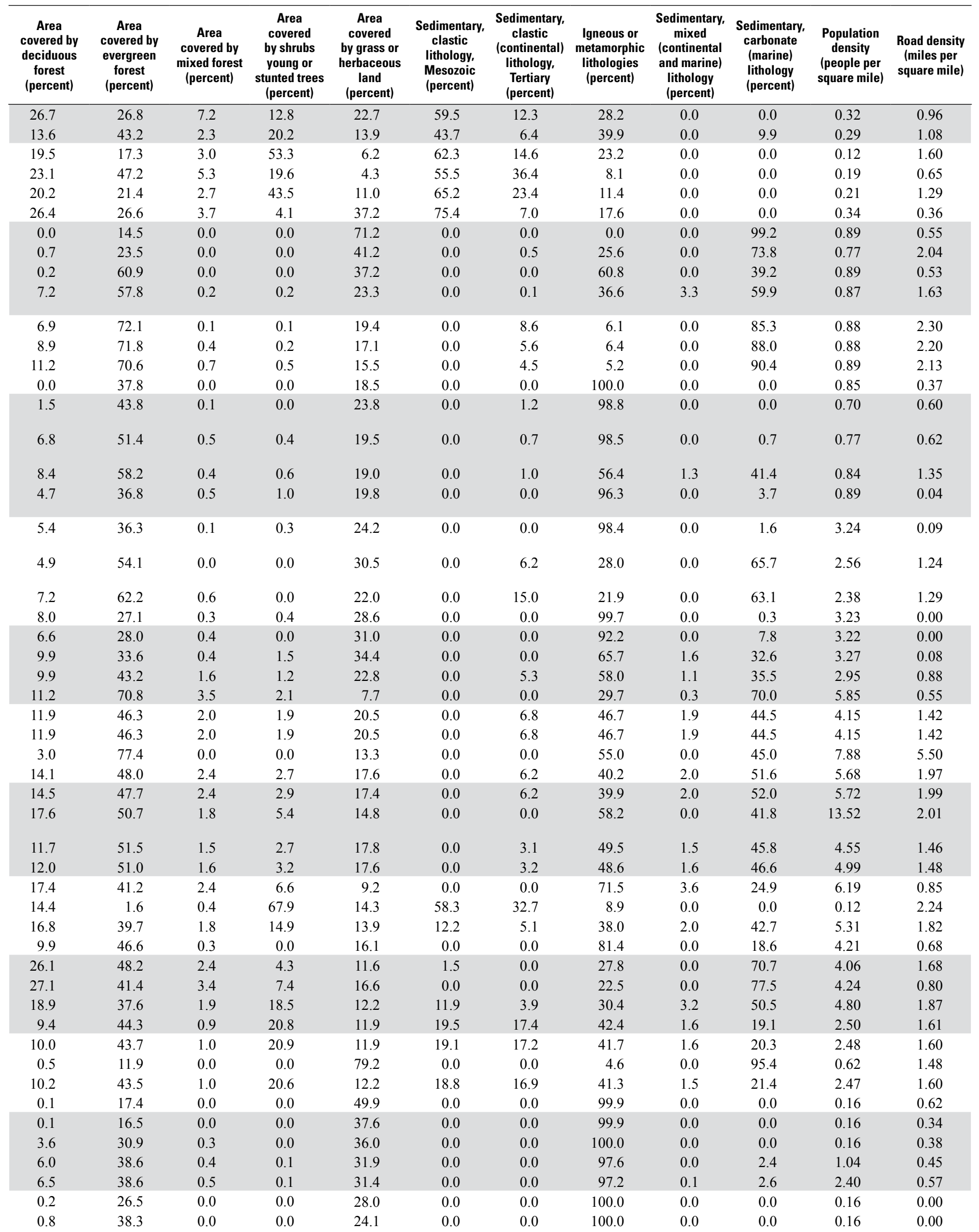


Appendix 1-1. Watershed characteristics for the U.S. Geological Survey streamgage network in the Upper Colorado River Basin.-Continued

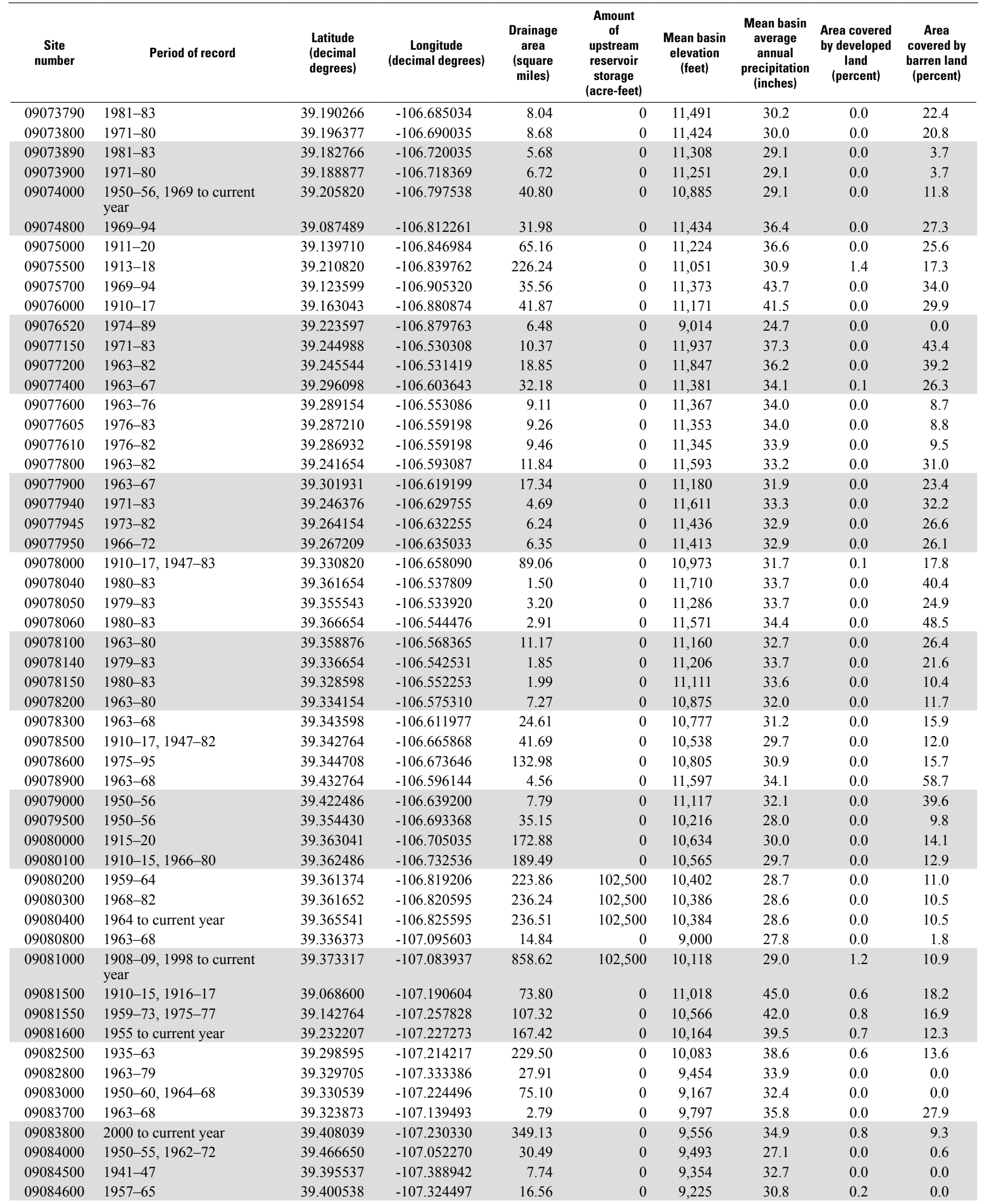




\begin{tabular}{|c|c|c|c|c|c|c|c|c|c|c|c|}
\hline $\begin{array}{c}\text { Area } \\
\text { covered by } \\
\text { deciduous } \\
\text { forest } \\
\text { (percent) }\end{array}$ & $\begin{array}{c}\text { Area } \\
\text { covered by } \\
\text { evergreen } \\
\text { forest } \\
\text { (percent) }\end{array}$ & $\begin{array}{c}\text { Area } \\
\text { covered by } \\
\text { mixed forest } \\
\text { (percent) }\end{array}$ & $\begin{array}{c}\text { Area } \\
\text { covered } \\
\text { by shrubs } \\
\text { young or } \\
\text { stunted trees } \\
\text { (percent) }\end{array}$ & $\begin{array}{c}\text { Area } \\
\text { covered } \\
\text { by grass or } \\
\text { herbaceeous } \\
\text { land } \\
\text { (percent) }\end{array}$ & $\begin{array}{c}\text { Sedimentary, } \\
\text { clastic } \\
\text { lithology, } \\
\text { Mesozoic } \\
\text { (percent) }\end{array}$ & $\begin{array}{l}\text { Sedimentary, } \\
\text { clastic } \\
\text { (continental) } \\
\text { lithology, } \\
\text { Tertiary } \\
\text { (percent) }\end{array}$ & $\begin{array}{c}\text { Igneous or } \\
\text { metamorphic } \\
\text { lithologies } \\
\text { (percent) }\end{array}$ & $\begin{array}{c}\text { Sedimentary, } \\
\text { mixed } \\
\text { (continental } \\
\text { and marine) } \\
\text { lithology } \\
\text { (percent) }\end{array}$ & $\begin{array}{c}\text { Sedimentary, } \\
\text { carbonate } \\
\text { (marine) } \\
\text { lithology } \\
\text { (percent) }\end{array}$ & $\begin{array}{c}\text { Population } \\
\text { density } \\
\text { (people per } \\
\text { square mile) }\end{array}$ & $\begin{array}{c}\text { Road density } \\
\text { (miles per } \\
\text { square mile) }\end{array}$ \\
\hline 0.4 & 44.1 & 0.0 & 0.0 & 30.0 & 0.0 & 0.0 & 100.0 & 0.0 & 0.0 & 0.15 & 0.00 \\
\hline 0.3 & 47.3 & 0.1 & 0.0 & 28.5 & 0.0 & 0.0 & 100.0 & 0.0 & 0.0 & 0.15 & 0.00 \\
\hline 0.0 & 59.1 & 0.0 & 0.0 & 31.2 & 0.0 & 0.0 & 100.0 & 0.0 & 0.0 & 0.15 & 0.00 \\
\hline 12.8 & 28.4 & 0.4 & 0.0 & 28.5 & 0.0 & 0.0 & 55.6 & 0.0 & 44.4 & 0.15 & 0.86 \\
\hline 15.5 & 30.6 & 1.0 & 0.1 & 25.0 & 0.0 & 0.0 & 45.4 & 0.0 & 54.6 & 1.53 & 0.71 \\
\hline 11.4 & 38.4 & 0.8 & 0.3 & 26.3 & 0.2 & 0.0 & 78.3 & 0.8 & 20.7 & 3.68 & 0.84 \\
\hline 11.9 & 21.2 & 0.6 & 0.0 & 28.7 & 0.0 & 0.0 & 22.2 & 0.0 & 77.8 & 3.88 & 0.12 \\
\hline 15.7 & 23.9 & 0.8 & 0.0 & 26.6 & 0.3 & 0.0 & 18.8 & 0.0 & 80.8 & 4.01 & 0.17 \\
\hline 0.1 & 34.2 & 0.0 & 0.0 & 51.2 & 0.0 & 0.0 & 99.9 & 0.0 & 0.0 & 0.37 & 1.13 \\
\hline 0.1 & 34.2 & 0.0 & 0.0 & 51.2 & 0.0 & 0.0 & 99.9 & 0.0 & 0.0 & 0.37 & 1.16 \\
\hline 0.1 & 34.6 & 0.0 & 0.0 & 50.2 & 0.0 & 0.0 & 99.9 & 0.0 & 0.0 & 0.37 & 1.13 \\
\hline 0.5 & 37.8 & 0.0 & 0.0 & 25.5 & 0.0 & 0.0 & 100.0 & 0.0 & 0.0 & 0.33 & 0.01 \\
\hline 1.3 & 48.7 & 0.6 & 0.0 & 22.1 & 0.0 & 0.0 & 100.0 & 0.0 & 0.0 & 0.34 & 0.08 \\
\hline 0.0 & 33.7 & 0.0 & 0.0 & 30.2 & 0.0 & 0.0 & 100.0 & 0.0 & 0.0 & 0.34 & 0.00 \\
\hline 0.5 & 40.6 & 0.0 & 0.0 & 29.3 & 0.0 & 0.0 & 100.0 & 0.0 & 0.0 & 0.34 & 0.07 \\
\hline 0.5 & 41.6 & 0.0 & 0.0 & 28.8 & 0.0 & 0.0 & 100.0 & 0.0 & 0.0 & 0.34 & 0.14 \\
\hline 5.6 & 47.6 & 0.7 & 0.9 & 23.1 & 0.0 & 0.0 & 99.1 & 0.0 & 0.9 & 0.35 & 0.55 \\
\hline 0.0 & 23.5 & 0.0 & 0.0 & 30.9 & 0.0 & 0.0 & 100.0 & 0.0 & 0.0 & 0.37 & 0.00 \\
\hline 0.3 & 49.7 & 0.0 & 0.0 & 20.6 & 0.0 & 0.0 & 100.0 & 0.0 & 0.0 & 0.35 & 0.00 \\
\hline 0.0 & 17.3 & 0.0 & 0.0 & 26.7 & 0.0 & 0.0 & 100.0 & 0.0 & 0.0 & 0.45 & 0.00 \\
\hline 8.0 & 27.4 & 0.1 & 0.0 & 18.6 & 0.0 & 0.0 & 89.2 & 0.0 & 10.8 & 0.61 & 0.81 \\
\hline 23.2 & 46.5 & 2.2 & 1.1 & 14.1 & 0.0 & 0.0 & 42.4 & 0.0 & 57.6 & 0.45 & 1.38 \\
\hline 11.7 & 49.6 & 1.2 & 1.7 & 18.1 & 0.0 & 0.3 & 85.5 & 0.0 & 14.2 & 0.37 & 0.75 \\
\hline 12.6 & 50.0 & 1.3 & 2.3 & 17.4 & 0.0 & 1.0 & 80.5 & 0.0 & 18.5 & 0.37 & 0.73 \\
\hline 15.8 & 47.6 & 1.5 & 3.3 & 17.0 & 0.0 & 2.3 & 69.4 & 0.0 & 28.3 & 0.38 & 0.77 \\
\hline 15.5 & 49.0 & 1.5 & 3.2 & 16.7 & 0.0 & 2.2 & 67.1 & 0.0 & 30.6 & 0.37 & 0.84 \\
\hline 15.5 & 49.0 & 1.5 & 3.2 & 16.7 & 0.0 & 2.2 & 67.1 & 0.0 & 30.7 & 0.37 & 0.84 \\
\hline 52.0 & 20.6 & 4.1 & 12.4 & 6.7 & 67.4 & 0.6 & 23.6 & 0.0 & 8.4 & 5.24 & 1.48 \\
\hline 21.6 & 36.1 & 1.5 & 7.8 & 16.8 & 12.4 & 1.9 & 47.3 & 2.6 & 35.8 & 2.91 & 1.06 \\
\hline 14.2 & 24.5 & 1.0 & 0.3 & 33.7 & 44.2 & 0.5 & 19.6 & 0.0 & 35.7 & 0.13 & 0.59 \\
\hline 22.4 & 24.5 & 2.3 & 1.3 & 26.0 & 40.9 & 6.1 & 28.5 & 0.0 & 24.5 & 0.14 & 0.73 \\
\hline 27.9 & 28.4 & 2.9 & 2.2 & 21.3 & 46.9 & 4.0 & 20.0 & 0.0 & 29.2 & 0.29 & 0.76 \\
\hline 26.1 & 30.1 & 3.0 & 3.0 & 19.9 & 34.9 & 2.9 & 27.1 & 0.0 & 35.1 & 0.37 & 0.63 \\
\hline 41.9 & 41.2 & 6.9 & 0.7 & 8.8 & 3.8 & 96.2 & 0.0 & 0.0 & 0.0 & 0.65 & 1.25 \\
\hline 38.4 & 42.8 & 4.8 & 5.6 & 7.9 & 43.4 & 51.7 & 0.0 & 0.0 & 4.9 & 0.61 & 0.85 \\
\hline 25.5 & 25.5 & 8.1 & 5.3 & 6.2 & 25.5 & 0.0 & 63.3 & 0.0 & 11.2 & 2.54 & 0.83 \\
\hline 29.8 & 31.6 & 3.2 & 6.4 & 14.9 & 35.6 & 17.3 & 19.2 & 0.9 & 27.0 & 1.52 & 0.86 \\
\hline 41.8 & 36.9 & 7.9 & 3.2 & 9.2 & 34.3 & 0.0 & 23.8 & 0.0 & 41.9 & 0.74 & 1.53 \\
\hline 53.1 & 24.5 & 10.6 & 0.2 & 9.7 & 0.0 & 100.0 & 0.0 & 0.0 & 0.0 & 2.50 & 1.77 \\
\hline 67.5 & 13.8 & 7.2 & 1.7 & 8.3 & 3.2 & 96.8 & 0.0 & 0.0 & 0.0 & 2.64 & 1.57 \\
\hline
\end{tabular}


Appendix 1-1. Watershed characteristics for the U.S. Geological Survey streamgage network in the Upper Colorado River Basin.-Continued

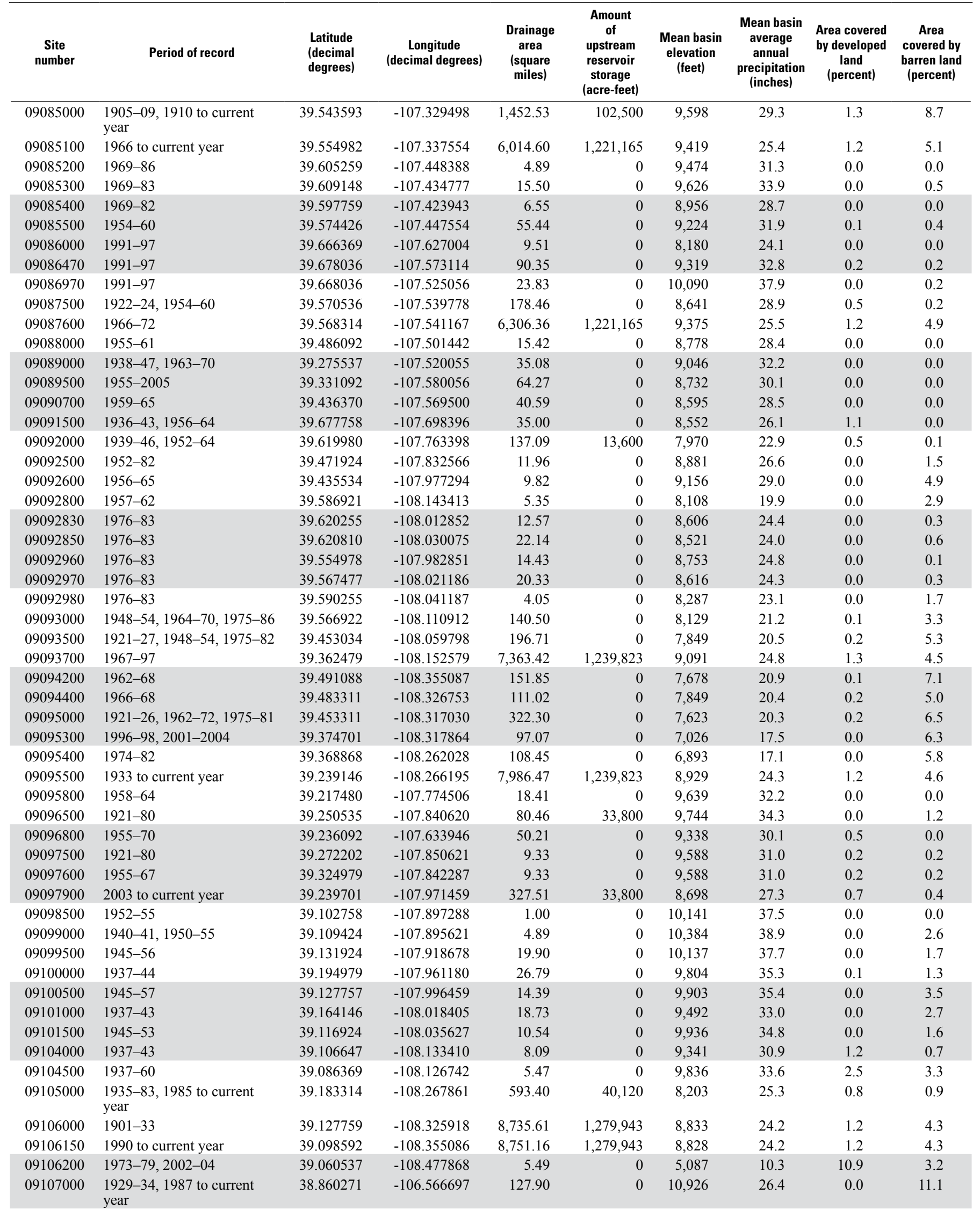




\begin{tabular}{|c|c|c|c|c|c|c|c|c|c|c|c|}
\hline $\begin{array}{c}\text { Area } \\
\text { covered by } \\
\text { deciduous } \\
\text { forest } \\
\text { (percent) }\end{array}$ & $\begin{array}{c}\text { Area } \\
\text { covered by } \\
\text { evergreen } \\
\text { forest } \\
\text { (percent) }\end{array}$ & $\begin{array}{c}\text { Area } \\
\text { covered by } \\
\text { mixed forest } \\
\text { (percent) }\end{array}$ & $\begin{array}{c}\text { Area } \\
\text { covered } \\
\text { by shrubs } \\
\text { young or } \\
\text { stunted trees } \\
\text { (percent) }\end{array}$ & $\begin{array}{c}\text { Area } \\
\text { covered } \\
\text { by grass or } \\
\text { herbaceous } \\
\text { land } \\
\text { (percent) }\end{array}$ & $\begin{array}{c}\text { Sedimentary, } \\
\text { clastic } \\
\text { lithology, } \\
\text { Mesozoic } \\
\text { (percent) }\end{array}$ & $\begin{array}{c}\text { Sedimentary, } \\
\text { clastic } \\
\text { (continental) } \\
\text { lithology, } \\
\text { Tertiary } \\
\text { (percent) }\end{array}$ & $\begin{array}{c}\text { Igneous or } \\
\text { metamorphic } \\
\text { lithologies } \\
\text { (percent) }\end{array}$ & $\begin{array}{c}\text { Sedimentary, } \\
\text { mixed } \\
\text { (continental } \\
\text { and marine) } \\
\text { lithology } \\
\text { (percent) }\end{array}$ & $\begin{array}{c}\text { Sedimentary, } \\
\text { carbonate } \\
\text { (marine) } \\
\text { lithology } \\
\text { (percent) }\end{array}$ & $\begin{array}{l}\text { Population } \\
\text { density } \\
\text { (people per } \\
\text { square mile) }\end{array}$ & $\begin{array}{c}\text { Road density } \\
\text { (miles per } \\
\text { square mile) }\end{array}$ \\
\hline 26.2 & 32.1 & 2.0 & 10.8 & 14.0 & 18.6 & 8.3 & 38.4 & 2.7 & 32.0 & 3.72 & 1.31 \\
\hline 14.1 & 40.7 & 1.3 & 18.3 & 12.7 & 18.8 & 14.8 & 40.6 & 1.8 & 24.0 & 2.81 & 1.53 \\
\hline 50.3 & 24.4 & 1.9 & 7.3 & 15.3 & 0.0 & 0.0 & 4.4 & 0.0 & 95.6 & 0.62 & 1.43 \\
\hline 28.4 & 30.1 & 2.1 & 9.3 & 25.9 & 0.0 & 2.5 & 17.3 & 0.0 & 80.2 & 1.09 & 0.89 \\
\hline 75.0 & 13.5 & 2.0 & 2.5 & 4.3 & 11.2 & 0.0 & 0.0 & 0.0 & 88.8 & 1.67 & 1.24 \\
\hline 33.2 & 26.2 & 4.8 & 4.8 & 29.3 & 0.0 & 0.0 & 1.2 & 0.0 & 98.8 & 2.10 & 0.78 \\
\hline 14.1 & 45.7 & 1.3 & 1.0 & 36.7 & 0.0 & 0.0 & 6.6 & 0.0 & 93.4 & 2.16 & 0.55 \\
\hline 28.1 & 32.7 & 2.9 & 10.4 & 20.6 & 14.7 & 0.1 & 1.5 & 0.0 & 83.8 & 2.06 & 1.06 \\
\hline 67.1 & 15.6 & 6.7 & 7.4 & 2.3 & 0.5 & 99.5 & 0.0 & 0.0 & 0.0 & 0.74 & 1.32 \\
\hline 56.3 & 18.7 & 7.0 & 3.5 & 12.6 & 0.0 & 4.6 & 0.0 & 0.0 & 95.4 & 0.47 & 1.18 \\
\hline 40.3 & 29.6 & 3.2 & 14.6 & 9.6 & 40.5 & 7.4 & 0.1 & 0.0 & 51.9 & 0.80 & 1.13 \\
\hline 50.8 & 27.1 & 1.7 & 9.5 & 8.9 & 10.9 & 84.7 & 4.4 & 0.0 & 0.0 & 0.46 & 1.57 \\
\hline 33.0 & 42.3 & 11.0 & 4.3 & 3.2 & 0.0 & 90.7 & 9.3 & 0.0 & 0.0 & 8.04 & 0.51 \\
\hline 33.1 & 3.3 & 0.0 & 60.0 & 0.5 & 0.0 & 100.0 & 0.0 & 0.0 & 0.0 & 0.15 & 1.58 \\
\hline 48.2 & 15.4 & 0.5 & 29.0 & 6.6 & 0.0 & 100.0 & 0.0 & 0.0 & 0.0 & 0.16 & 1.42 \\
\hline 41.5 & 16.4 & 0.3 & 35.5 & 5.6 & 0.0 & 100.0 & 0.0 & 0.0 & 0.0 & 0.16 & 1.48 \\
\hline 57.0 & 5.9 & 0.2 & 30.0 & 6.7 & 0.0 & 100.0 & 0.0 & 0.0 & 0.0 & 0.17 & 0.89 \\
\hline 57.2 & 6.3 & 0.2 & 30.5 & 5.3 & 0.0 & 100.0 & 0.0 & 0.0 & 0.0 & 0.16 & 0.78 \\
\hline 50.9 & 14.7 & 0.0 & 29.0 & 3.2 & 0.0 & 100.0 & 0.0 & 0.0 & 0.0 & 0.15 & 0.86 \\
\hline 37.6 & 13.6 & 0.1 & 41.9 & 2.3 & 0.0 & 100.0 & 0.0 & 0.0 & 0.0 & 0.16 & 1.45 \\
\hline 39.7 & 42.7 & 4.2 & 0.5 & 10.4 & 7.7 & 44.4 & 47.9 & 0.0 & 0.0 & 0.39 & 0.12 \\
\hline 30.3 & 44.0 & 1.9 & 1.9 & 15.6 & 4.4 & 28.6 & 67.0 & 0.0 & 0.0 & 0.39 & 0.49 \\
\hline 56.6 & 25.9 & 4.1 & 4.2 & 7.5 & 0.0 & 75.6 & 23.2 & 1.2 & 0.0 & 0.39 & 0.63 \\
\hline 43.8 & 26.2 & 3.6 & 1.7 & 24.2 & 0.0 & 100.0 & 0.0 & 0.0 & 0.0 & 0.40 & 0.27 \\
\hline 43.8 & 26.2 & 3.6 & 1.7 & 24.2 & 0.0 & 100.0 & 0.0 & 0.0 & 0.0 & 0.40 & 0.27 \\
\hline 48.2 & 20.9 & 2.3 & 13.0 & 7.5 & 1.7 & 68.6 & 27.7 & 1.9 & 0.0 & 0.39 & 0.81 \\
\hline 4.0 & 73.7 & 1.2 & 0.0 & 5.8 & 0.0 & 0.0 & 100.0 & 0.0 & 0.0 & 0.39 & 0.71 \\
\hline 3.3 & 61.1 & 0.5 & 0.0 & 26.3 & 0.0 & 0.0 & 100.0 & 0.0 & 0.0 & 0.39 & 0.36 \\
\hline 15.8 & 57.4 & 3.9 & 0.0 & 15.6 & 0.0 & 5.5 & 94.5 & 0.0 & 0.0 & 0.42 & 0.82 \\
\hline 23.7 & 49.7 & 6.8 & 0.7 & 12.9 & 0.0 & 7.2 & 92.8 & 0.0 & 0.0 & 0.42 & 0.95 \\
\hline 24.3 & 51.6 & 11.1 & 0.3 & 4.6 & 0.0 & 13.0 & 87.0 & 0.0 & 0.0 & 0.43 & 0.89 \\
\hline 31.3 & 43.8 & 11.5 & 1.8 & 3.8 & 0.0 & 20.8 & 79.2 & 0.0 & 0.0 & 0.43 & 0.94 \\
\hline 18.6 & 58.5 & 14.3 & 0.0 & 3.3 & 0.0 & 6.7 & 93.3 & 0.0 & 0.0 & 0.42 & 0.54 \\
\hline 46.9 & 22.8 & 9.2 & 6.2 & 5.9 & 0.0 & 13.7 & 86.3 & 0.0 & 0.0 & 0.42 & 1.46 \\
\hline 28.7 & 49.2 & 6.3 & 0.4 & 3.7 & 0.0 & 6.1 & 93.9 & 0.0 & 0.0 & 0.42 & 1.54 \\
\hline 35.6 & 28.7 & 3.0 & 16.7 & 5.5 & 4.2 & 61.3 & 31.2 & 3.3 & 0.0 & 0.41 & 1.01 \\
\hline 18.2 & 37.2 & 1.3 & 21.1 & 10.1 & 16.6 & 31.1 & 30.3 & 2.1 & 19.8 & 2.40 & 1.47 \\
\hline 18.2 & 37.2 & 1.3 & 21.1 & 10.1 & 16.7 & 31.1 & 30.3 & 2.1 & 19.8 & 2.43 & 1.47 \\
\hline 0.0 & 0.6 & 0.0 & 79.2 & 0.0 & 86.0 & 0.1 & 0.0 & 13.9 & 0.0 & 58.51 & 2.56 \\
\hline 1.5 & 53.0 & 0.0 & 0.2 & 27.6 & 0.0 & 0.0 & 91.9 & 2.8 & 5.3 & 0.12 & 0.70 \\
\hline
\end{tabular}


Appendix 1-1. Watershed characteristics for the U.S. Geological Survey streamgage network in the Upper Colorado River Basin.-Continued

\begin{tabular}{|c|c|c|c|c|c|c|c|c|c|}
\hline $\begin{array}{c}\text { Site } \\
\text { number }\end{array}$ & Period of record & $\begin{array}{l}\text { Latitude } \\
\text { (decimal } \\
\text { degrees) }\end{array}$ & $\begin{array}{c}\text { Longitude } \\
\text { (decimal degrees) }\end{array}$ & $\begin{array}{c}\text { Drainage } \\
\text { area } \\
\text { (square } \\
\text { miles) }\end{array}$ & $\begin{array}{c}\text { Amount } \\
\text { of } \\
\text { upstream } \\
\text { reservoir } \\
\text { storage } \\
\text { (acre-feet) }\end{array}$ & $\begin{array}{c}\text { Mean basin } \\
\text { elevation } \\
\text { (feet) }\end{array}$ & $\begin{array}{l}\text { Mean basin } \\
\text { average } \\
\text { annual } \\
\text { precipitation } \\
\text { (inches) }\end{array}$ & $\begin{array}{c}\text { Area covered } \\
\text { by developed } \\
\text { land } \\
\text { (percent) }\end{array}$ & $\begin{array}{c}\text { Area } \\
\text { covered by } \\
\text { barren land } \\
\text { (percent) }\end{array}$ \\
\hline 09108000 & $1913-14,1929-34$ & 38.816105 & -106.529473 & 59.20 & 0 & 10,968 & 22.3 & 0.5 & 7.9 \\
\hline 09109000 & $\begin{array}{l}1929-34,1938 \text { to current } \\
\text { year }\end{array}$ & 38.818327 & -106.609198 & 254.46 & 106,200 & 10,875 & 24.5 & 0.3 & 11.4 \\
\hline 09110000 & 1910 to current year & 38.664437 & -106.845317 & 477.40 & 106,200 & 10,647 & 23.9 & 0.3 & 8.1 \\
\hline 09111000 & $1941-46$ & 38.856382 & -107.055881 & 8.79 & 0 & 10,563 & 32.9 & 1.2 & 0.9 \\
\hline 09111500 & $1940-51,1993-2006$ & 38.869715 & -106.969489 & 68.33 & 0 & 10,333 & 33.2 & 1.5 & 7.8 \\
\hline 09112000 & $1910-13,1940-51$ & 38.824437 & -106.852817 & 33.04 & 0 & 10,807 & 32.0 & 0.0 & 5.8 \\
\hline 09112200 & $\begin{array}{l}1963-72,1979-81,1993 \text { to } \\
\text { current year }\end{array}$ & 38.784160 & -106.870874 & 240.93 & 0 & 10,473 & 33.6 & 1.0 & 9.5 \\
\hline 09112500 & $\begin{array}{l}1905,1910-22,1934 \text { to cur- } \\
\text { rent year }\end{array}$ & 38.664437 & -106.848095 & 288.85 & 0 & 10,271 & 31.6 & 1.0 & 8.0 \\
\hline 09113980 & 1998 to current year & 38.587770 & -106.931432 & 160.56 & 0 & 9,566 & 24.2 & 0.4 & 3.8 \\
\hline 09114000 & $1944-50$ & 38.575269 & -106.938655 & 163.20 & 0 & 9,540 & 23.9 & 0.4 & 3.8 \\
\hline 09114500 & $\begin{array}{l}1910-28,1944 \text { to current } \\
\text { year }\end{array}$ & 38.541936 & -106.949766 & $1,010.15$ & 106,200 & 10,210 & 25.5 & 0.6 & 6.7 \\
\hline 09115500 & $\begin{array}{l}\text { 1916-22, 1937-72, } 1992 \text { to } \\
\text { current year }\end{array}$ & 38.411663 & -106.422806 & 148.45 & 0 & 10,234 & 21.8 & 0.6 & 1.9 \\
\hline 09116000 & $1944-50$ & 38.412495 & -106.507253 & 194.89 & 0 & 10,088 & 21.3 & 0.7 & 1.6 \\
\hline 09117000 & $1944-51,1963-70$ & 38.497214 & -106.726147 & 426.73 & 0 & 9,605 & 18.5 & 0.7 & 0.9 \\
\hline 09118000 & $1937-50,1959-70$ & 38.559715 & -106.636422 & 106.94 & 0 & 10,617 & 23.5 & 0.1 & 6.3 \\
\hline 09118450 & 1981 to current year & 38.335549 & -106.772260 & 333.76 & 0 & 10,198 & 19.8 & 0.3 & 1.9 \\
\hline 09118500 & $1940-48$ & 38.399992 & -106.765315 & 360.08 & 0 & 10,116 & 19.3 & 0.3 & 1.8 \\
\hline 09119000 & 1910,1937 to current year & 38.521658 & -106.940877 & $1,058.59$ & 0 & 9,735 & 18.7 & 0.6 & 1.6 \\
\hline 09124700 & $1963-68$ & 38.452214 & -107.348112 & $3,456.67$ & $1,046,900$ & 9,919 & 21.4 & 0.6 & 4.4 \\
\hline 09125000 & $1945-72$ & 38.487767 & -107.415057 & 35.02 & 0 & 9,671 & 21.8 & 0.0 & 0.1 \\
\hline 09126000 & 1954 to current year & 38.257213 & -107.546726 & 66.88 & 13,520 & 10,862 & 32.7 & 0.0 & 20.2 \\
\hline 09126500 & $1902-05,1962-67$ & 38.441099 & -107.554225 & 210.95 & 13,520 & 9,764 & 25.4 & 0.4 & 7.4 \\
\hline 09127000 & $1942-52$ & 38.446377 & -107.555614 & 230.46 & 13,520 & 9,631 & 24.6 & 0.5 & 6.8 \\
\hline 09127500 & $1916-19,1945-54,1960-69$ & 38.551933 & -107.506169 & 42.27 & 0 & 9,623 & 20.3 & 0.0 & 0.4 \\
\hline 09128000 & 1903 to current year & 38.529153 & -107.648947 & $3,970.10$ & $1,202,856$ & 9,872 & 21.5 & 0.6 & 4.3 \\
\hline 09128500 & $1935-94$ & 38.727768 & -107.506723 & 43.09 & 0 & 9,164 & 25.7 & 0.0 & 4.8 \\
\hline 09129000 & $1954-60$ & 38.710544 & -107.576169 & 63.69 & 0 & 8,920 & 24.8 & 0.1 & 3.7 \\
\hline 09129600 & $1976-87$ & 38.707486 & -107.710336 & 166.86 & 23,395 & 8,096 & 19.5 & 1.6 & 1.6 \\
\hline 09129800 & $1965-73$ & 39.143318 & -107.431165 & 38.37 & 0 & 9,300 & 33.3 & 0.0 & 0.3 \\
\hline 09130500 & $1934-53$ & 39.013322 & -107.358385 & 132.97 & 0 & 8,692 & 28.6 & 0.6 & 2.0 \\
\hline 09130600 & $1955-65$ & 39.130817 & -107.575334 & 7.40 & 0 & 9,423 & 29.7 & 0.0 & 0.5 \\
\hline 09130800 & $1968-74$ & 39.115540 & -107.524500 & 27.57 & 0 & 9,275 & 29.2 & 0.7 & 0.1 \\
\hline 09131100 & $1968-82$ & 39.104150 & -107.584501 & 11.90 & 5,990 & 10,208 & 33.9 & 0.0 & 2.7 \\
\hline 09131200 & $1961-73$ & 39.089708 & -107.505333 & 49.82 & 5,990 & 9,403 & 29.9 & 0.6 & 0.7 \\
\hline 09131500 & $1949-55$ & 38.939990 & -107.358108 & 257.13 & 26,940 & 8,651 & 27.3 & 0.5 & 1.7 \\
\hline 09132000 & $1938-43,1954-58$ & 38.863048 & -107.163939 & 21.12 & 0 & 10,323 & 36.3 & 0.8 & 7.7 \\
\hline 09132050 & $1977-81$ & 38.953880 & -107.273662 & 95.25 & 0 & 9,631 & 32.9 & 0.4 & 9.4 \\
\hline 09132500 & 1933 to current year & 38.925823 & -107.434221 & 526.23 & 26,940 & 8,888 & 28.2 & 0.5 & 4.5 \\
\hline 09132700 & $1960-68$ & 39.056928 & -107.629502 & 1.35 & 0 & 10,320 & 34.2 & 0.0 & 0.3 \\
\hline 09132800 & $1960-68$ & 39.049428 & -107.620891 & 1.43 & 0 & 10,438 & 34.5 & 0.0 & 0.1 \\
\hline
\end{tabular}




\begin{tabular}{|c|c|c|c|c|c|c|c|c|c|c|c|}
\hline $\begin{array}{c}\text { Area } \\
\text { covered by } \\
\text { deciduous } \\
\text { forest } \\
\text { (percent) }\end{array}$ & $\begin{array}{c}\text { Area } \\
\text { covered by } \\
\text { evergreen } \\
\text { forest } \\
\text { (percent) }\end{array}$ & $\begin{array}{c}\text { Area } \\
\text { covered by } \\
\text { mixed forest } \\
\text { (percent) }\end{array}$ & $\begin{array}{c}\text { Area } \\
\text { covered } \\
\text { by shrubs } \\
\text { young or } \\
\text { stunted trees } \\
\text { (percent) }\end{array}$ & $\begin{array}{c}\text { Area } \\
\text { covered } \\
\text { by grass or } \\
\text { herbaceous } \\
\text { land } \\
\text { (percent) }\end{array}$ & $\begin{array}{c}\text { Sedimentary, } \\
\text { clastic } \\
\text { lithology, } \\
\text { Mesozoic } \\
\text { (percent) }\end{array}$ & $\begin{array}{c}\text { Sedimentary, } \\
\text { clastic } \\
\text { (continental) } \\
\text { lithology, } \\
\text { Tertiary } \\
\text { (percent) }\end{array}$ & $\begin{array}{c}\text { Igneous or } \\
\text { metamorphic } \\
\text { lithologies } \\
\text { (percent) }\end{array}$ & $\begin{array}{c}\text { Sedimentary, } \\
\text { mixed } \\
\text { (continental } \\
\text { and marine) } \\
\text { lithology } \\
\text { (percent) }\end{array}$ & $\begin{array}{c}\text { Sedimentary, } \\
\text { carbonate } \\
\text { (marine) } \\
\text { lithology } \\
\text { (percent) }\end{array}$ & $\begin{array}{l}\text { Population } \\
\text { density } \\
\text { (people per } \\
\text { square mile) }\end{array}$ & $\begin{array}{l}\text { Road density } \\
\text { (miles per } \\
\text { square mile) }\end{array}$ \\
\hline 1.8 & 64.0 & 0.0 & 0.1 & 20.5 & 0.0 & 0.0 & 83.9 & 5.5 & 10.5 & 0.12 & 1.36 \\
\hline 1.5 & 54.9 & 0.0 & 0.3 & 24.5 & 0.0 & 1.1 & 87.8 & 4.6 & 6.5 & 0.12 & 0.83 \\
\hline 6.1 & 69.3 & 0.0 & 0.0 & 18.0 & 0.0 & 30.0 & 70.0 & 0.0 & 0.0 & 2.16 & 2.19 \\
\hline 18.5 & 35.6 & 0.4 & 1.3 & 28.4 & 65.9 & 9.2 & 24.8 & 0.0 & 0.0 & 3.26 & 2.11 \\
\hline 13.3 & 42.0 & 1.5 & 0.7 & 33.3 & 2.4 & 0.0 & 10.7 & 0.0 & 87.0 & 0.67 & 0.77 \\
\hline 17.3 & 31.9 & 0.9 & 2.4 & 29.9 & 42.0 & 4.0 & 24.7 & 1.8 & 27.5 & 1.91 & 1.41 \\
\hline 20.0 & 28.8 & 1.0 & 7.8 & 26.4 & 45.1 & 6.0 & 23.3 & 2.4 & 23.2 & 1.71 & 1.41 \\
\hline 28.3 & 27.3 & 2.8 & 17.8 & 11.4 & 30.0 & 38.9 & 28.8 & 2.2 & 0.0 & 0.79 & 1.13 \\
\hline 27.9 & 26.9 & 2.8 & 18.3 & 11.2 & 29.5 & 39.2 & 29.0 & 2.2 & 0.0 & 0.79 & 1.19 \\
\hline 13.9 & 40.4 & 1.2 & 10.9 & 19.9 & 20.5 & 9.2 & 53.6 & 2.6 & 14.1 & 0.90 & 1.14 \\
\hline 7.0 & 67.6 & 1.9 & 5.3 & 12.6 & 4.6 & 0.0 & 86.6 & 0.0 & 8.8 & 0.08 & 0.86 \\
\hline 7.2 & 67.5 & 2.0 & 6.6 & 11.4 & 3.5 & 0.1 & 89.7 & 0.0 & 6.7 & 0.08 & 0.73 \\
\hline 7.6 & 49.6 & 1.8 & 26.9 & 7.8 & 20.4 & 8.5 & 68.0 & 0.0 & 3.1 & 0.08 & 1.05 \\
\hline 6.6 & 62.1 & 1.4 & 3.8 & 17.4 & 0.8 & 0.0 & 75.9 & 0.0 & 23.3 & 0.13 & 1.60 \\
\hline 11.1 & 41.1 & 0.7 & 6.0 & 35.2 & 1.9 & 7.3 & 89.1 & 1.6 & 0.0 & 0.04 & 0.94 \\
\hline 11.0 & 39.2 & 1.0 & 10.1 & 33.1 & 4.2 & 7.2 & 87.0 & 1.5 & 0.0 & 0.04 & 0.99 \\
\hline 8.8 & 40.6 & 1.3 & 26.3 & 16.6 & 13.4 & 6.9 & 75.6 & 0.5 & 3.6 & 0.51 & 1.21 \\
\hline 12.1 & 37.9 & 1.2 & 22.0 & 17.5 & 11.7 & 7.5 & 74.4 & 1.1 & 5.2 & 0.59 & 1.13 \\
\hline 26.9 & 52.7 & 1.1 & 3.9 & 14.6 & 0.0 & 10.1 & 89.9 & 0.0 & 0.0 & 0.04 & 0.55 \\
\hline 12.0 & 46.4 & 2.9 & 0.0 & 16.9 & 0.0 & 19.7 & 80.3 & 0.0 & 0.0 & 0.08 & 0.50 \\
\hline 24.4 & 40.5 & 2.6 & 9.6 & 12.0 & 9.6 & 38.1 & 51.5 & 0.8 & 0.0 & 0.60 & 1.12 \\
\hline 25.2 & 37.9 & 2.4 & 12.8 & 11.4 & 11.7 & 40.3 & 47.3 & 0.7 & 0.0 & 0.74 & 1.18 \\
\hline 43.1 & 31.8 & 1.6 & 6.9 & 15.5 & 20.7 & 13.4 & 65.8 & 0.1 & 0.0 & 0.08 & 0.92 \\
\hline 14.4 & 37.8 & 1.3 & 20.6 & 16.9 & 11.3 & 9.3 & 73.8 & 1.0 & 4.6 & 0.58 & 1.15 \\
\hline 52.9 & 15.6 & 4.8 & 6.3 & 14.9 & 39.2 & 13.0 & 47.8 & 0.0 & 0.0 & 0.14 & 0.33 \\
\hline 52.6 & 16.0 & 4.0 & 8.1 & 13.1 & 44.1 & 13.4 & 42.4 & 0.0 & 0.0 & 0.46 & 0.42 \\
\hline 36.2 & 22.0 & 2.1 & 18.9 & 5.4 & 64.2 & 16.3 & 18.9 & 0.5 & 0.0 & 0.90 & 1.52 \\
\hline 65.0 & 19.4 & 2.0 & 1.8 & 10.8 & 19.5 & 78.7 & 0.0 & 1.8 & 0.0 & 0.14 & 0.18 \\
\hline 61.8 & 12.6 & 3.1 & 9.4 & 6.8 & 11.0 & 79.0 & 6.6 & 3.3 & 0.0 & 0.15 & 0.64 \\
\hline 36.8 & 32.3 & 10.9 & 0.3 & 16.0 & 0.0 & 86.2 & 2.7 & 11.1 & 0.0 & 0.58 & 0.26 \\
\hline 57.9 & 17.7 & 5.4 & 1.1 & 14.9 & 0.0 & 76.5 & 20.5 & 3.0 & 0.0 & 0.58 & 0.39 \\
\hline 5.6 & 74.4 & 0.5 & 0.0 & 13.5 & 0.0 & 36.1 & 63.9 & 0.0 & 0.0 & 0.58 & 0.34 \\
\hline 43.9 & 31.9 & 5.5 & 1.3 & 12.9 & 0.0 & 64.3 & 34.0 & 1.7 & 0.0 & 0.58 & 0.44 \\
\hline 59.0 & 14.6 & 3.5 & 10.5 & 6.6 & 7.5 & 79.2 & 11.3 & 2.1 & 0.0 & 0.24 & 0.61 \\
\hline 18.2 & 53.6 & 0.9 & 0.1 & 15.0 & 15.5 & 52.2 & 32.3 & 0.0 & 0.0 & 0.65 & 1.52 \\
\hline 40.1 & 29.3 & 2.1 & 3.3 & 12.9 & 30.7 & 39.8 & 29.5 & 0.0 & 0.0 & 0.24 & 0.54 \\
\hline 53.3 & 19.7 & 3.3 & 8.1 & 8.1 & 21.7 & 57.4 & 19.9 & 1.0 & 0.0 & 0.20 & 0.54 \\
\hline 5.9 & 86.2 & 0.4 & 0.0 & 5.9 & 0.0 & 59.9 & 40.1 & 0.0 & 0.0 & 0.58 & 0.00 \\
\hline 1.7 & 92.6 & 0.2 & 0.1 & 3.1 & 0.0 & 59.9 & 40.1 & 0.0 & 0.0 & 0.58 & 0.00 \\
\hline
\end{tabular}


Appendix 1-1. Watershed characteristics for the U.S. Geological Survey streamgage network in the Upper Colorado River Basin.-Continued

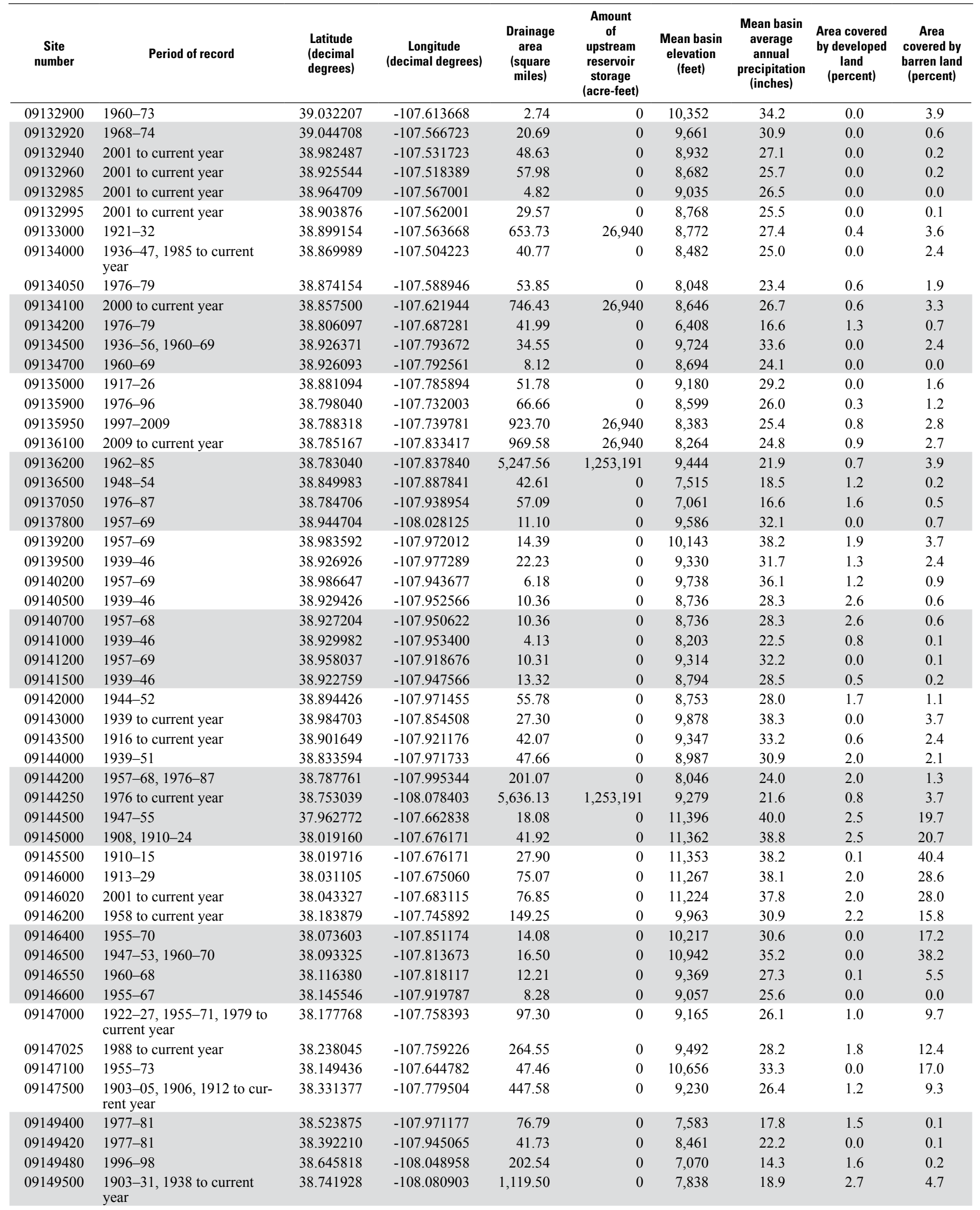




\begin{tabular}{|c|c|c|c|c|c|c|c|c|c|c|c|}
\hline $\begin{array}{c}\text { Area } \\
\text { covered by } \\
\text { deciduous } \\
\text { forest } \\
\text { (percent) }\end{array}$ & $\begin{array}{c}\text { Area } \\
\text { covered by } \\
\text { evergreen } \\
\text { forest } \\
\text { (percent) }\end{array}$ & $\begin{array}{c}\text { Area } \\
\text { covered by } \\
\text { mixed forest } \\
\text { (percent) }\end{array}$ & $\begin{array}{c}\text { Area } \\
\text { covered } \\
\text { by shrubs } \\
\text { young or } \\
\text { stunted trees } \\
\text { (percent) }\end{array}$ & $\begin{array}{c}\text { Area } \\
\text { covered } \\
\text { by grass or } \\
\text { herbaceous } \\
\text { land } \\
\text { (percent) }\end{array}$ & $\begin{array}{c}\text { Sedimentary, } \\
\text { clastic } \\
\text { lithology, } \\
\text { Mesozoic } \\
\text { (percent) }\end{array}$ & $\begin{array}{l}\text { Sedimentary, } \\
\text { clastic } \\
\text { (continental) } \\
\text { lithology, } \\
\text { Tertiary } \\
\text { (percent) }\end{array}$ & $\begin{array}{l}\text { Igneous or } \\
\text { metamorphic } \\
\text { lithologies } \\
\text { (percent) }\end{array}$ & $\begin{array}{c}\text { Sedimentary, } \\
\text { mixed } \\
\text { (continental } \\
\text { and marine) } \\
\text { lithology } \\
\text { (percent) }\end{array}$ & $\begin{array}{c}\text { Sedimentary, } \\
\text { carbonate } \\
\text { (marine) } \\
\text { lithology } \\
\text { (percent) }\end{array}$ & $\begin{array}{l}\text { Population } \\
\text { density } \\
\text { (people per } \\
\text { square mile) }\end{array}$ & $\begin{array}{c}\text { Road density } \\
\text { (miles per } \\
\text { square mile) }\end{array}$ \\
\hline 1.8 & 91.4 & 0.0 & 0.1 & 2.3 & 0.0 & 58.9 & 41.1 & 0.0 & 0.0 & 0.58 & 0.00 \\
\hline 32.7 & 53.5 & 4.7 & 0.1 & 7.8 & 0.0 & 56.4 & 37.1 & 6.5 & 0.0 & 0.58 & 0.30 \\
\hline 62.4 & 27.1 & 3.4 & 2.0 & 3.9 & 2.4 & 75.2 & 19.5 & 2.8 & 0.0 & 0.53 & 0.45 \\
\hline 70.1 & 15.8 & 3.5 & 5.0 & 4.7 & 41.2 & 58.8 & 0.0 & 0.0 & 0.0 & 0.58 & 0.21 \\
\hline 55.5 & 19.2 & 3.1 & 8.8 & 7.1 & 25.1 & 56.4 & 17.5 & 1.0 & 0.0 & 0.29 & 0.54 \\
\hline 59.0 & 12.6 & 4.4 & 16.3 & 4.2 & 66.9 & 13.8 & 19.3 & 0.0 & 0.0 & 0.49 & 0.76 \\
\hline 47.0 & 13.5 & 3.4 & 27.5 & 3.1 & 70.9 & 13.3 & 15.2 & 0.7 & 0.0 & 1.41 & 0.91 \\
\hline 54.4 & 18.9 & 3.0 & 10.5 & 6.5 & 31.4 & 51.1 & 16.4 & 1.1 & 0.0 & 0.62 & 0.66 \\
\hline 33.4 & 32.7 & 1.3 & 11.9 & 10.4 & 41.8 & 24.0 & 23.7 & 10.5 & 0.0 & 1.82 & 0.83 \\
\hline 47.1 & 20.7 & 2.5 & 14.3 & 6.2 & 37.6 & 44.4 & 15.4 & 2.6 & 0.0 & 1.10 & 0.77 \\
\hline 44.9 & 20.3 & 2.4 & 15.5 & 5.9 & 39.1 & 42.3 & 14.6 & 3.9 & 0.0 & 1.22 & 0.82 \\
\hline 20.7 & 34.1 & 1.5 & 20.2 & 14.1 & 19.9 & 15.4 & 59.7 & 1.5 & 3.5 & 0.74 & 1.11 \\
\hline 33.4 & 26.8 & 0.1 & 27.8 & 1.5 & 70.1 & 18.4 & 0.3 & 11.3 & 0.0 & 1.93 & 0.75 \\
\hline 25.0 & 23.0 & 0.1 & 34.9 & 1.1 & 67.8 & 14.2 & 0.2 & 17.8 & 0.0 & 2.32 & 1.12 \\
\hline 49.9 & 30.1 & 4.0 & 1.3 & 9.6 & 6.0 & 73.0 & 20.9 & 0.0 & 0.0 & 1.14 & 0.21 \\
\hline 17.2 & 54.8 & 3.2 & 0.4 & 10.3 & 0.0 & 14.8 & 85.2 & 0.0 & 0.0 & 1.73 & 1.53 \\
\hline 30.0 & 44.9 & 2.4 & 4.0 & 6.9 & 12.7 & 23.4 & 57.7 & 6.3 & 0.0 & 1.54 & 1.66 \\
\hline 38.5 & 38.3 & 2.3 & 0.6 & 8.5 & 0.0 & 10.2 & 89.8 & 0.0 & 0.0 & 2.15 & 1.91 \\
\hline 34.1 & 34.9 & 1.4 & 8.1 & 5.3 & 11.6 & 13.6 & 53.8 & 21.0 & 0.0 & 2.07 & 2.29 \\
\hline 34.1 & 34.9 & 1.4 & 8.1 & 5.3 & 11.6 & 13.6 & 53.8 & 21.0 & 0.0 & 2.07 & 2.29 \\
\hline 20.6 & 33.2 & 1.4 & 21.2 & 13.3 & 22.3 & 15.5 & 56.7 & 2.3 & 3.2 & 1.05 & 1.15 \\
\hline 11.7 & 27.9 & 0.8 & 0.1 & 35.3 & 0.0 & 0.0 & 97.9 & 0.0 & 2.1 & 1.09 & 1.32 \\
\hline 9.7 & 28.3 & 0.8 & 0.4 & 35.8 & 0.0 & 0.0 & 92.4 & 6.0 & 1.7 & 0.93 & 1.04 \\
\hline 7.8 & 29.1 & 1.1 & 0.3 & 19.4 & 3.5 & 0.0 & 88.9 & 0.0 & 7.6 & 1.09 & 0.74 \\
\hline 8.9 & 29.6 & 0.9 & 0.5 & 27.9 & 1.8 & 0.0 & 88.4 & 3.7 & 6.1 & 1.00 & 1.07 \\
\hline 9.0 & 30.4 & 0.9 & 0.6 & 27.4 & 2.2 & 0.0 & 87.4 & 3.6 & 6.8 & 1.00 & 1.08 \\
\hline 22.2 & 33.1 & 1.5 & 2.9 & 16.3 & 20.0 & 8.1 & 58.6 & 6.6 & 6.7 & 1.25 & 1.61 \\
\hline 22.4 & 48.4 & 1.9 & 0.2 & 9.9 & 22.6 & 31.6 & 45.8 & 0.0 & 0.0 & 1.08 & 0.68 \\
\hline 17.7 & 32.0 & 3.1 & 0.1 & 8.1 & 3.0 & 26.3 & 70.7 & 0.0 & 0.0 & 1.10 & 0.38 \\
\hline 37.6 & 46.7 & 4.7 & 0.3 & 4.4 & 31.6 & 39.7 & 28.8 & 0.0 & 0.0 & 1.08 & 0.88 \\
\hline 26.8 & 9.8 & 0.0 & 1.2 & 62.1 & 100.0 & 0.0 & 0.0 & 0.0 & 0.0 & 0.92 & 1.93 \\
\hline 28.3 & 35.9 & 1.5 & 2.7 & 14.9 & 55.1 & 20.6 & 24.3 & 0.0 & 0.0 & 1.04 & 1.39 \\
\hline 23.2 & 36.0 & 1.4 & 3.7 & 14.7 & 37.6 & 12.8 & 42.1 & 3.7 & 3.8 & 1.15 & 1.65 \\
\hline 14.8 & 39.8 & 2.5 & 0.6 & 24.5 & 2.2 & 2.9 & 92.5 & 0.0 & 2.4 & 1.08 & 0.15 \\
\hline 26.0 & 39.0 & 1.4 & 4.7 & 12.6 & 38.4 & 18.8 & 37.4 & 2.9 & 2.5 & 1.08 & 1.41 \\
\hline 22.8 & 40.6 & 0.2 & 16.1 & 1.4 & 92.4 & 0.1 & 0.0 & 7.4 & 0.0 & 5.75 & 2.05 \\
\hline 38.9 & 51.5 & 0.4 & 6.3 & 2.3 & 100.0 & 0.0 & 0.0 & 0.0 & 0.0 & 0.78 & 0.98 \\
\hline 13.7 & 33.4 & 0.3 & 34.2 & 2.8 & 84.4 & 5.5 & 0.0 & 10.1 & 0.0 & 1.47 & 1.84 \\
\hline 18.5 & 32.6 & 0.7 & 19.2 & 6.3 & 59.8 & 18.8 & 15.1 & 5.4 & 1.0 & 4.46 & 2.13 \\
\hline
\end{tabular}


Appendix 1-1. Watershed characteristics for the U.S. Geological Survey streamgage network in the Upper Colorado River Basin.-Continued

\begin{tabular}{|c|c|c|c|c|c|c|c|c|c|}
\hline $\begin{array}{c}\text { Site } \\
\text { number }\end{array}$ & Period of record & $\begin{array}{l}\text { Latitude } \\
\text { (decimal } \\
\text { degrees) }\end{array}$ & $\begin{array}{c}\text { Longitude } \\
\text { (decimal degrees) }\end{array}$ & $\begin{array}{c}\text { Drainage } \\
\text { area } \\
\text { (square } \\
\text { miles) }\end{array}$ & $\begin{array}{c}\text { Amount } \\
\text { of } \\
\text { upstream } \\
\text { reservoir } \\
\text { storage } \\
\text { (acre-feet) }\end{array}$ & $\begin{array}{l}\text { Mean basin } \\
\text { elevation } \\
\text { (feet) }\end{array}$ & $\begin{array}{l}\text { Mean basin } \\
\text { average } \\
\text { annual } \\
\text { precipitation } \\
\text { (inches) }\end{array}$ & $\begin{array}{c}\text { Area covered } \\
\text { by developed } \\
\text { land } \\
\text { (percent) }\end{array}$ & $\begin{array}{c}\text { Area } \\
\text { covered by } \\
\text { barren land } \\
\text { (percent) }\end{array}$ \\
\hline 09149900 & $1980-81$ & 38.479710 & -108.313414 & 8.57 & 0 & 8,856 & 31.2 & 0.3 & 0.0 \\
\hline 09149910 & $1980-81$ & 38.614986 & -108.206742 & 26.38 & 0 & 7,688 & 19.1 & 0.1 & 1.5 \\
\hline 09150500 & $1938-54,1976-83$ & 38.734984 & -108.161740 & 248.74 & 0 & 7,272 & 17.1 & 1.0 & 1.0 \\
\hline 09152500 & $\begin{array}{l}1896-99,1901-06,1916 \text { to } \\
\text { current year }\end{array}$ & 38.983316 & -108.450645 & $7,920.38$ & $1,258,943$ & 8,753 & 20.4 & 1.1 & 3.5 \\
\hline 09152520 & $2000-2003$ & 38.989149 & -108.448700 & 7.30 & 0 & 4,809 & 9.3 & 3.7 & 10.2 \\
\hline 09152900 & $1973-83$ & 39.136925 & -108.697320 & 15.62 & 0 & 5,230 & 10.8 & 2.3 & 1.7 \\
\hline 09153000 & $1907-23$ & 39.137481 & -108.730933 & $17,049.88$ & $2,538,886$ & 8,719 & 22.1 & 1.4 & 3.9 \\
\hline 09153270 & $1973-77$ & 39.163592 & -108.750933 & 170.92 & 0 & 5,994 & 13.5 & 0.3 & 2.4 \\
\hline 09160000 & $1976-82$ & 39.331090 & -108.930940 & 1.82 & 0 & 5,040 & 11.5 & 0.0 & 0.2 \\
\hline 09160500 & $1976-82$ & 39.323312 & -108.930662 & 2.11 & 0 & 5,024 & 11.4 & 0.0 & 0.2 \\
\hline 09161000 & $1976-82$ & 39.329423 & -108.943163 & 0.21 & 0 & 5,037 & 11.2 & 0.0 & 0.0 \\
\hline 09163050 & $1973-82$ & 39.293313 & -108.933718 & 6.61 & 0 & 4,933 & 10.9 & 0.1 & 0.1 \\
\hline 09163310 & $1973-82$ & 39.297201 & -108.866771 & 196.78 & 0 & 6,350 & 15.1 & 0.5 & 1.9 \\
\hline 09163340 & $1973-82$ & 39.265813 & -108.842881 & 15.56 & 0 & 4,980 & 9.9 & 0.8 & 0.1 \\
\hline 09163490 & $1973-83$ & 39.221647 & -108.892883 & 436.42 & 0 & 6,160 & 14.4 & 0.9 & 1.6 \\
\hline 09163500 & 1951 to current year & 39.132760 & -109.027055 & $17,848.75$ & $2,538,886$ & 8,591 & 21.7 & 1.4 & 3.8 \\
\hline 09163570 & $1983-88$ & 38.850817 & -108.782879 & 0.71 & 0 & 9,332 & 24.0 & 0.0 & 0.0 \\
\hline 09163675 & $1983-86$ & 39.081652 & -109.217615 & 171.19 & 0 & 6,207 & 13.7 & 0.1 & 1.3 \\
\hline 09165000 & $\begin{array}{l}1951-96,1998 \text { to current } \\
\text { year }\end{array}$ & 37.638884 & -108.060352 & 105.53 & 0 & 10,631 & 35.9 & 0.6 & 6.3 \\
\hline 09168500 & $1953-56$ & 37.912769 & -108.650096 & 168.19 & 0 & 7,812 & 20.8 & 0.0 & 0.6 \\
\hline 09168730 & $\begin{array}{l}1997-2003,2008 \text { to current } \\
\text { year }\end{array}$ & 38.044437 & -108.905382 & $1,430.17$ & 21,711 & 8,342 & 24.1 & 0.3 & 1.2 \\
\hline 09168800 & $1979-81$ & 38.113603 & -108.858713 & 44.15 & 0 & 6,245 & 14.1 & 0.5 & 1.9 \\
\hline 09169500 & $\begin{array}{l}1917-22,1971 \text { to current } \\
\text { year }\end{array}$ & 38.310268 & -108.885381 & $2,020.43$ & 21,711 & 7,863 & 21.9 & 0.3 & 1.4 \\
\hline 09170500 & $1944-52$ & 38.383322 & -108.996773 & 24.04 & 0 & 7,743 & 23.9 & 0.0 & 0.0 \\
\hline 09170800 & $1971-73$ & 38.331656 & -108.900381 & 54.61 & 0 & 6,663 & 19.4 & 1.7 & 0.7 \\
\hline 09171000 & $1944-52$ & 38.329990 & -108.871769 & 55.91 & 0 & 6,625 & 19.2 & 1.9 & 0.7 \\
\hline 09171100 & 1971 to current year & 38.356934 & -108.833435 & $2,142.65$ & 21,711 & 7,763 & 21.6 & 0.4 & 1.4 \\
\hline 09171200 & $1959-65$ & 37.948049 & -107.877009 & 42.76 & 0 & 11,173 & 36.8 & 2.5 & 27.3 \\
\hline 09171500 & $1895-99,1910$ & 37.992770 & -108.023957 & 175.95 & 0 & 10,482 & 33.1 & 1.3 & 18.8 \\
\hline 09172000 & $1941-59$ & 37.958326 & -108.005901 & 1.08 & 0 & 9,247 & 25.0 & 0.0 & 0.0 \\
\hline 09172100 & $1955-63$ & 38.101658 & -107.923398 & 9.52 & 0 & 9,658 & 27.2 & 0.8 & 5.9 \\
\hline 09172500 & $\begin{array}{l}1909-12,1930-34,1942 \text { to } \\
\text { current year }\end{array}$ & 38.042491 & -108.132296 & 309.74 & 0 & 9,944 & 30.2 & 0.9 & 11.9 \\
\hline 09172600 & $1976-80$ & 37.923326 & -108.131741 & 4.77 & 0 & 10,125 & 35.1 & 0.0 & 0.5 \\
\hline 09172800 & $1976-80$ & 37.889159 & -108.197578 & 5.34 & 0 & 10,612 & 36.6 & 0.0 & 4.3 \\
\hline 09173000 & $1941-61,1962-67,1975-81$ & 37.969992 & -108.195633 & 40.73 & 0 & 10,084 & 34.5 & 0.0 & 3.8 \\
\hline 09173500 & $1942-51$ & 38.203878 & -108.057570 & 29.26 & 0 & 8,985 & 25.3 & 0.0 & 0.0 \\
\hline 09174000 & $1953-62$ & 38.263045 & -108.397863 & 650.18 & 0 & 9,212 & 26.9 & 0.5 & 5.9 \\
\hline 09174500 & $1942-51$ & 38.273601 & -108.362862 & 38.28 & 0 & 7,645 & 19.7 & 0.6 & 0.0 \\
\hline 09174600 & 1995 to current year & 38.244157 & -108.502034 & 743.95 & 0 & 8,955 & 25.7 & 0.5 & 5.2 \\
\hline
\end{tabular}




\begin{tabular}{|c|c|c|c|c|c|c|c|c|c|c|c|}
\hline $\begin{array}{c}\text { Area } \\
\text { covered by } \\
\text { deciduous } \\
\text { forest } \\
\text { (percent) }\end{array}$ & $\begin{array}{c}\text { Area } \\
\text { covered by } \\
\text { evergreen } \\
\text { forest } \\
\text { (percent) }\end{array}$ & $\begin{array}{c}\text { Area } \\
\text { covered by } \\
\text { mixed forest } \\
\text { (percent) }\end{array}$ & $\begin{array}{c}\text { Area } \\
\text { covered } \\
\text { by shrubs } \\
\text { young or } \\
\text { stunted trees } \\
\text { (percent) }\end{array}$ & $\begin{array}{c}\text { Area } \\
\text { covered } \\
\text { by grass or } \\
\text { herbaceous } \\
\text { land } \\
\text { (percent) }\end{array}$ & $\begin{array}{c}\text { Sedimentary, } \\
\text { clastic } \\
\text { lithology, } \\
\text { Mesozoic } \\
\text { (percent) }\end{array}$ & $\begin{array}{c}\text { Sedimentary, } \\
\text { clastic } \\
\text { (continental) } \\
\text { lithology, } \\
\text { Tertiary } \\
\text { (percent) }\end{array}$ & $\begin{array}{l}\text { Igneous or } \\
\text { metamorphic } \\
\text { lithologies } \\
\text { (percent) }\end{array}$ & $\begin{array}{c}\text { Sedimentary, } \\
\text { mixed } \\
\text { (continental } \\
\text { and marine) } \\
\text { lithology } \\
\text { (percent) }\end{array}$ & $\begin{array}{c}\text { Sedimentary, } \\
\text { carbonate } \\
\text { (marine) } \\
\text { lithology } \\
\text { (percent) }\end{array}$ & $\begin{array}{l}\text { Population } \\
\text { density } \\
\text { (people per } \\
\text { square mile) }\end{array}$ & $\begin{array}{c}\text { Road density } \\
\text { (miles per } \\
\text { square mile) }\end{array}$ \\
\hline 51.8 & 42.2 & 0.7 & 0.9 & 3.8 & 100.0 & 0.0 & 0.0 & 0.0 & 0.0 & 0.39 & 0.82 \\
\hline 28.0 & 46.9 & 0.2 & 21.3 & 1.4 & 100.0 & 0.0 & 0.0 & 0.0 & 0.0 & 0.39 & 1.00 \\
\hline 23.8 & 36.9 & 0.4 & 28.7 & 0.9 & 93.0 & 0.0 & 0.3 & 4.0 & 2.7 & 0.41 & 1.17 \\
\hline 19.8 & 33.3 & 1.2 & 23.2 & 10.9 & 37.3 & 14.4 & 43.1 & 2.7 & 2.5 & 1.49 & 1.23 \\
\hline 0.0 & 0.0 & 0.0 & 80.4 & 0.1 & 77.7 & 22.3 & 0.0 & 0.0 & 0.0 & 1.66 & 2.10 \\
\hline 0.4 & 9.5 & 0.0 & 62.4 & 0.0 & 91.7 & 0.1 & 0.0 & 8.2 & 0.0 & 4.15 & 1.72 \\
\hline 18.6 & 35.0 & 1.2 & 22.7 & 10.3 & 27.7 & 22.7 & 35.6 & 2.6 & 11.3 & 2.81 & 1.40 \\
\hline 6.8 & 28.5 & 0.0 & 55.0 & 0.4 & 75.1 & 24.6 & 0.0 & 0.3 & 0.0 & 1.68 & 1.11 \\
\hline 0.0 & 0.0 & 0.0 & 99.8 & 0.0 & 100.0 & 0.0 & 0.0 & 0.0 & 0.0 & 1.43 & 1.54 \\
\hline 0.0 & 0.0 & 0.0 & 99.8 & 0.0 & 100.0 & 0.0 & 0.0 & 0.0 & 0.0 & 1.43 & 1.48 \\
\hline 0.0 & 0.0 & 0.0 & 100.0 & 0.0 & 100.0 & 0.0 & 0.0 & 0.0 & 0.0 & 1.43 & 3.94 \\
\hline 0.0 & 0.0 & 0.0 & 99.5 & 0.0 & 100.0 & 0.0 & 0.0 & 0.0 & 0.0 & 1.43 & 2.11 \\
\hline 13.7 & 36.4 & 0.0 & 45.6 & 0.6 & 73.6 & 26.4 & 0.0 & 0.0 & 0.0 & 0.37 & 0.78 \\
\hline 0.0 & 0.7 & 0.0 & 94.8 & 0.1 & 100.0 & 0.0 & 0.0 & 0.0 & 0.0 & 1.43 & 1.78 \\
\hline 10.9 & 32.3 & 0.0 & 49.6 & 0.6 & 76.4 & 23.6 & 0.0 & 0.0 & 0.0 & 0.51 & 1.02 \\
\hline 18.1 & 34.7 & 1.2 & 24.0 & 9.8 & 30.0 & 22.6 & 34.0 & 2.6 & 10.8 & 2.77 & 1.39 \\
\hline 21.8 & 43.4 & 34.5 & 0.2 & 0.1 & 100.0 & 0.0 & 0.0 & 0.0 & 0.0 & 0.19 & 0.21 \\
\hline 0.4 & 39.1 & 0.0 & 57.7 & 0.7 & 41.7 & 58.3 & 0.0 & 0.0 & 0.0 & 0.08 & 0.43 \\
\hline 17.4 & 55.8 & 2.9 & 0.1 & 15.8 & 46.2 & 4.7 & 13.0 & 0.5 & 35.6 & 0.07 & 0.85 \\
\hline 34.1 & 37.8 & 0.3 & 21.1 & 4.4 & 98.1 & 1.0 & 0.9 & 0.0 & 0.0 & 0.06 & 1.04 \\
\hline 29.3 & 42.9 & 1.7 & 17.0 & 5.2 & 91.3 & 1.4 & 2.3 & 0.0 & 5.0 & 0.27 & 1.28 \\
\hline 0.0 & 21.3 & 0.0 & 74.7 & 0.5 & 57.5 & 17.7 & 0.0 & 0.0 & 24.8 & 0.23 & 2.08 \\
\hline 22.0 & 43.5 & 1.2 & 25.3 & 3.9 & 91.1 & 2.3 & 1.7 & 0.6 & 4.3 & 0.24 & 1.52 \\
\hline 12.8 & 74.2 & 0.0 & 10.8 & 1.1 & 100.0 & 0.0 & 0.0 & 0.0 & 0.0 & 0.18 & 2.00 \\
\hline 6.1 & 55.0 & 0.0 & 26.1 & 0.6 & 75.3 & 20.8 & 0.0 & 1.1 & 2.8 & 0.23 & 2.36 \\
\hline 6.0 & 53.7 & 0.0 & 26.3 & 0.6 & 73.5 & 22.6 & 0.0 & 1.1 & 2.7 & 0.23 & 2.40 \\
\hline 20.9 & 43.2 & 1.1 & 26.6 & 3.7 & 89.1 & 3.9 & 1.6 & 0.9 & 4.4 & 0.24 & 1.55 \\
\hline 15.1 & 26.1 & 3.0 & 0.2 & 23.1 & 19.7 & 9.4 & 65.3 & 0.0 & 5.6 & 8.36 & 2.06 \\
\hline 24.9 & 28.1 & 4.4 & 0.9 & 20.2 & 45.6 & 9.3 & 41.9 & 0.0 & 3.2 & 3.92 & 1.77 \\
\hline 32.9 & 1.2 & 0.0 & 0.4 & 65.1 & 100.0 & 0.0 & 0.0 & 0.0 & 0.0 & 0.54 & 2.10 \\
\hline 33.1 & 26.5 & 1.7 & 0.2 & 31.5 & 57.1 & 12.7 & 30.2 & 0.0 & 0.0 & 0.57 & 1.72 \\
\hline 29.9 & 30.3 & 4.4 & 1.6 & 20.1 & 63.4 & 6.5 & 26.1 & 0.0 & 4.0 & 2.46 & 1.69 \\
\hline 47.8 & 29.4 & 9.1 & 0.0 & 13.1 & 98.7 & 0.0 & 1.3 & 0.0 & 0.0 & 0.53 & 0.48 \\
\hline 8.7 & 65.0 & 6.5 & 0.0 & 15.3 & 67.1 & 0.0 & 32.9 & 0.0 & 0.0 & 0.23 & 2.07 \\
\hline 32.3 & 38.7 & 10.7 & 0.1 & 14.3 & 79.8 & 0.0 & 20.2 & 0.0 & 0.0 & 0.34 & 1.24 \\
\hline 54.0 & 10.3 & 0.0 & 2.3 & 32.7 & 90.2 & 9.8 & 0.0 & 0.0 & 0.0 & 0.50 & 1.75 \\
\hline 33.8 & 36.5 & 3.1 & 3.3 & 15.4 & 80.4 & 3.5 & 13.8 & 0.0 & 2.3 & 1.39 & 1.47 \\
\hline 46.4 & 37.1 & 0.2 & 7.1 & 1.4 & 98.0 & 2.0 & 0.0 & 0.0 & 0.0 & 0.50 & 1.25 \\
\hline 33.2 & 38.7 & 2.7 & 4.3 & 13.5 & 82.3 & 3.7 & 12.1 & 0.0 & 2.0 & 1.27 & 1.43 \\
\hline
\end{tabular}


Appendix 1-1. Watershed characteristics for the U.S. Geological Survey streamgage network in the Upper Colorado River Basin.-Continued

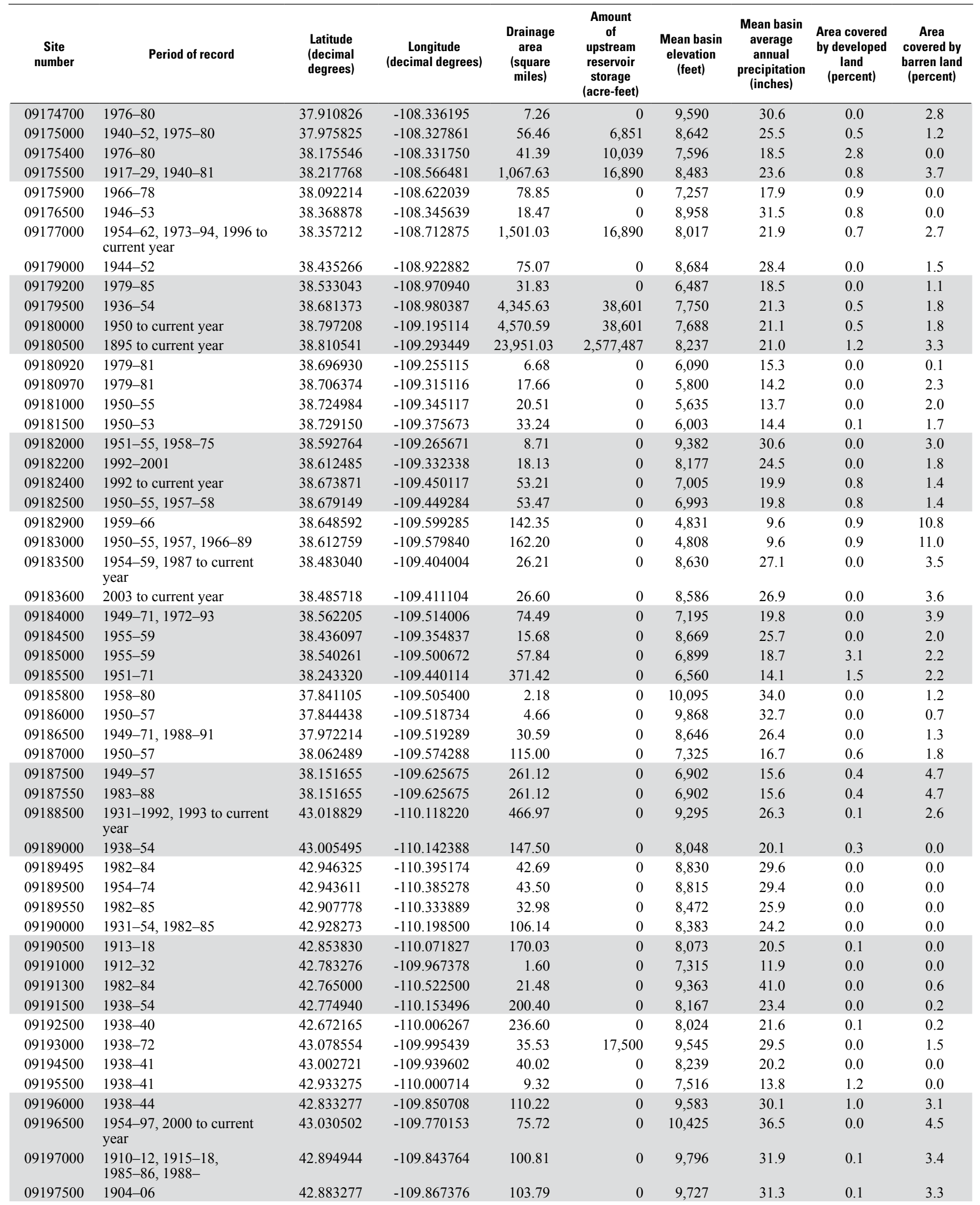




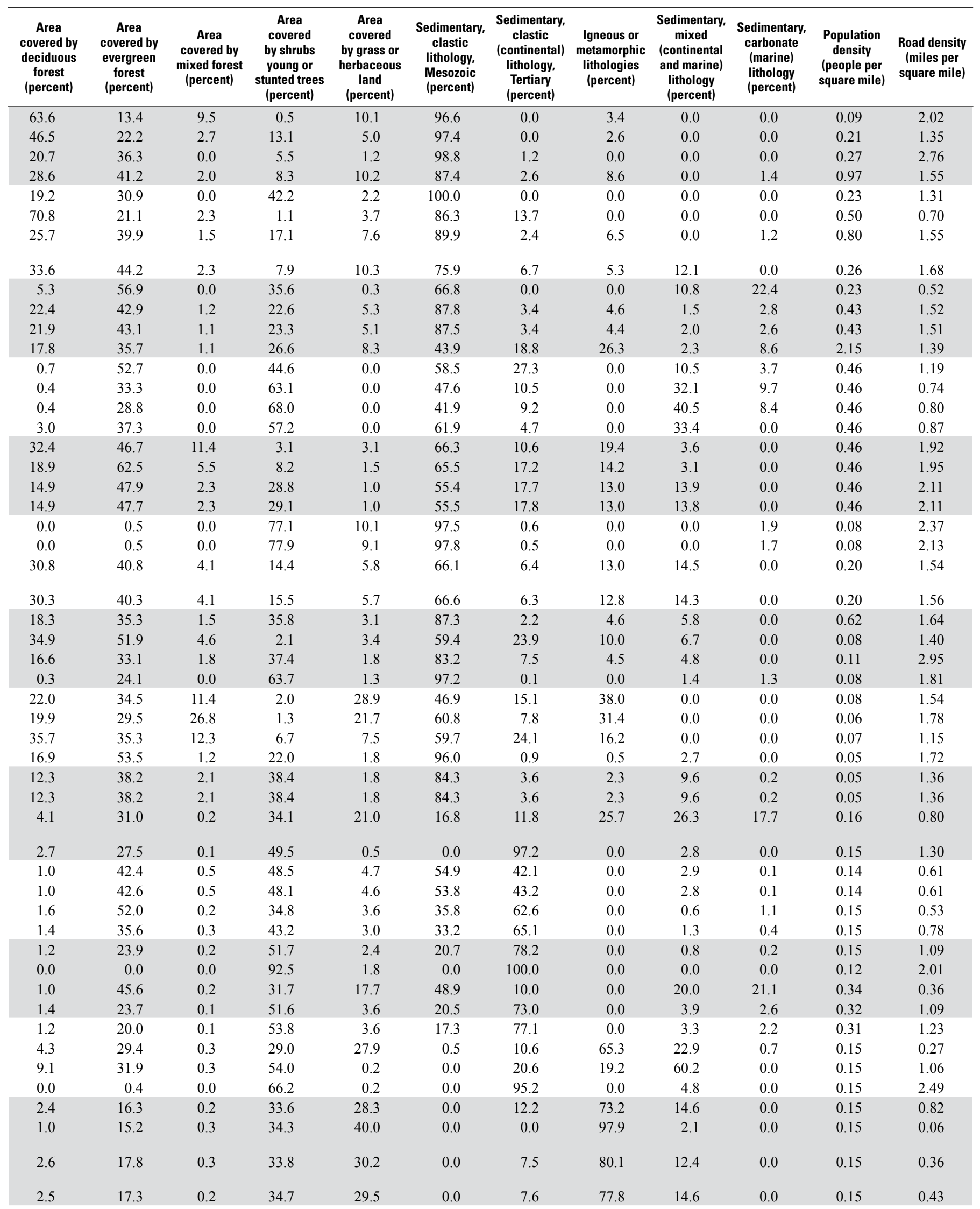


Appendix 1-1. Watershed characteristics for the U.S. Geological Survey streamgage network in the Upper Colorado River Basin.-Continued

\begin{tabular}{|c|c|c|c|c|c|c|c|c|c|}
\hline $\begin{array}{c}\text { Site } \\
\text { number }\end{array}$ & Period of record & $\begin{array}{l}\text { Latitude } \\
\text { (decimal } \\
\text { degrees) }\end{array}$ & $\begin{array}{c}\text { Longitude } \\
\text { (decimal degrees) }\end{array}$ & $\begin{array}{c}\text { Drainage } \\
\text { area } \\
\text { (square } \\
\text { miles) }\end{array}$ & $\begin{array}{c}\text { Amount } \\
\text { of } \\
\text { upstream } \\
\text { reservoir } \\
\text { storage } \\
\text { (acre-feet) }\end{array}$ & $\begin{array}{l}\text { Mean basin } \\
\text { elevation } \\
\text { (feet) }\end{array}$ & $\begin{array}{l}\text { Mean basin } \\
\text { average } \\
\text { annual } \\
\text { precipitation } \\
\text { (inches) }\end{array}$ & $\begin{array}{c}\text { Area covered } \\
\text { by developed } \\
\text { land } \\
\text { (percent) }\end{array}$ & $\begin{array}{c}\text { Area } \\
\text { covered by } \\
\text { barren land } \\
\text { (percent) }\end{array}$ \\
\hline 09198000 & $1903-04,1914-54$ & 42.866610 & -109.867376 & 104.40 & 0 & 9,713 & 31.2 & 0.2 & 3.3 \\
\hline 09198500 & $1938-71$ & 42.881389 & -109.711944 & 82.49 & 0 & 9,634 & 31.1 & 0.0 & 1.6 \\
\hline 09199000 & 1904-06 & 42.833278 & -109.750704 & 41.15 & 0 & 9,243 & 28.0 & 0.1 & 0.5 \\
\hline 09201000 & $1914-69$ & 42.750222 & -109.728758 & 535.52 & 40,130 & 8,678 & 23.2 & 0.8 & 1.0 \\
\hline 09201500 & $1938-39$ & 42.856337 & -109.617366 & 1.20 & 0 & 7,677 & 15.1 & 0.0 & 0.0 \\
\hline 09202000 & $1938-73$ & 42.819390 & -109.717092 & 136.45 & 22,280 & 9,634 & 30.7 & 0.0 & 1.5 \\
\hline 09203000 & 1938-92 & 42.672500 & -109.421667 & 81.96 & 0 & 9,763 & 30.3 & 0.0 & 1.5 \\
\hline 09204000 & $1938-71$ & 42.743611 & -109.510833 & 44.78 & 0 & 9,642 & 29.9 & 0.0 & 0.1 \\
\hline 09204500 & $1904-06,1914-24,1930-32$ & 42.699945 & -109.717367 & 0.11 & 0 & 6,932 & 9.8 & 24.4 & 0.0 \\
\hline 09207500 & $1938-42$ & 42.511051 & -110.309055 & 50.79 & 0 & 8,798 & 32.0 & 0.0 & 0.8 \\
\hline 09207700 & $1965-73$ & 42.390219 & -110.253219 & 67.96 & 0 & 8,361 & 23.3 & 0.3 & 0.2 \\
\hline 09208000 & $1940-42,1950-81$ & 42.506944 & -110.674722 & 6.59 & 0 & 9,003 & 36.6 & 0.0 & 0.0 \\
\hline 09208400 & $1982-84$ & 42.293827 & -110.440724 & 122.08 & 0 & 8,600 & 28.6 & 0.0 & 0.1 \\
\hline 09208500 & $1913-16,1940-49$ & 42.222163 & -110.320165 & 167.09 & 0 & 8,419 & 25.9 & 0.0 & 0.1 \\
\hline 09209400 & 1963 to current year & 42.192722 & -110.163214 & $3,824.58$ & 67,621 & 8,139 & 19.7 & 0.5 & 1.0 \\
\hline 09210000 & $1941-42$ & 42.161050 & -110.525726 & 60.90 & 0 & 8,379 & 26.5 & 0.0 & 0.1 \\
\hline 09210500 & 1951 to current year & 42.096053 & -110.416556 & 153.77 & 0 & 8,112 & 22.8 & 0.0 & 0.1 \\
\hline 09211000 & $1914-19,1931-53$ & 42.097167 & -110.222939 & 210.66 & 0 & 7,828 & 19.5 & 0.0 & 0.9 \\
\hline 09211200 & 1963 to current year & 42.021060 & -110.049876 & $4,197.74$ & 412,921 & 8,077 & 19.3 & 0.5 & 1.2 \\
\hline 09212500 & $1910-11,1939-87$ & 42.571339 & -109.283461 & 93.89 & 0 & 9,523 & 28.2 & 0.0 & 1.3 \\
\hline 09213500 & $\begin{array}{l}1914-17,1920-24,1926- \\
34,1953 \text { to current year }\end{array}$ & 42.316895 & -109.485687 & 322.71 & 0 & 7,862 & 15.9 & 0.5 & 0.4 \\
\hline 09216545 & $1975-81$ & 41.493018 & -108.513716 & 305.57 & 0 & 7,183 & 8.2 & 0.2 & 0.5 \\
\hline 09216562 & $1976-81$ & 41.647741 & -108.997896 & 973.63 & 0 & 7,011 & 8.2 & 0.7 & 0.6 \\
\hline 09216565 & $1976-81$ & 41.198850 & -108.998453 & 34.69 & 0 & 7,770 & 13.7 & 0.0 & 0.0 \\
\hline 09216576 & $1975-76$ & 41.206906 & -109.053177 & 35.90 & 0 & 7,597 & 12.9 & 0.0 & 0.0 \\
\hline 09216578 & $1976-80$ & 41.217184 & -108.916228 & 3.75 & 0 & 7,603 & 12.5 & 0.0 & 0.0 \\
\hline 09216750 & $1976-81$ & 41.630519 & -108.989007 & 522.63 & 0 & 7,262 & 11.1 & 0.2 & 0.2 \\
\hline 09217000 & 1951 to current year & 41.516354 & -109.449023 & $9,733.40$ & 460,121 & 7,455 & 13.9 & 0.6 & 1.3 \\
\hline 09217900 & $\begin{array}{l}1937-1939,1966-86,1992 \\
\text { to current year }\end{array}$ & 40.959113 & -110.580166 & 124.60 & 0 & 10,473 & 34.2 & 0.3 & 17.3 \\
\hline 09218500 & $1939-98$ & 41.031614 & -110.579332 & 137.71 & 32,470 & 10,338 & 33.4 & 0.3 & 15.7 \\
\hline 09219000 & $1913-24,1937-55$ & 41.349951 & -110.334046 & 274.54 & 32,470 & 8,953 & 24.1 & 1.4 & 7.9 \\
\hline 09220000 & $\begin{array}{l}1939-99,2001 \text { to current } \\
\text { year }\end{array}$ & 41.054114 & -110.398492 & 55.38 & 14,000 & 10,363 & 31.3 & 0.6 & 10.3 \\
\hline 09220500 & $1939-81$ & 41.022169 & -110.479329 & 38.12 & 0 & 9,786 & 28.6 & 0.7 & 0.7 \\
\hline 09221500 & $1941-57$ & 41.266617 & -110.334045 & 210.59 & 14,000 & 9,099 & 23.7 & 1.2 & 2.8 \\
\hline 09222000 & $1937-57,1962-83$ & 41.452176 & -110.172929 & 799.72 & 46,470 & 8,297 & 18.9 & 1.8 & 3.7 \\
\hline 09222200 & $1980-81$ & 41.560504 & -110.659061 & 53.81 & 0 & 7,287 & 13.3 & 0.0 & 0.0 \\
\hline 09222250 & $1980-81$ & 41.582778 & -110.568889 & 388.28 & 0 & 7,233 & 13.3 & 0.7 & 0.4 \\
\hline 09222300 & $1976-80$ & 41.581615 & -110.562391 & 470.56 & 0 & 7,186 & 12.8 & 1.1 & 0.4 \\
\hline 09222400 & $1975-81$ & 41.538008 & -110.229321 & 970.20 & 0 & 7,171 & 12.9 & 0.8 & 1.1 \\
\hline
\end{tabular}




\begin{tabular}{|c|c|c|c|c|c|c|c|c|c|c|c|}
\hline $\begin{array}{c}\text { Area } \\
\text { covered by } \\
\text { deciduous } \\
\text { forest } \\
\text { (percent) }\end{array}$ & $\begin{array}{c}\text { Area } \\
\text { covered by } \\
\text { evergreen } \\
\text { forest } \\
\text { (percent) }\end{array}$ & $\begin{array}{c}\text { Area } \\
\text { covered by } \\
\text { mixed forest } \\
\text { (percent) }\end{array}$ & $\begin{array}{c}\text { Area } \\
\text { covered } \\
\text { by shrubs } \\
\text { young or } \\
\text { stunted trees } \\
\text { (percent) }\end{array}$ & $\begin{array}{c}\text { Area } \\
\text { covered } \\
\text { by grass or } \\
\text { herbaceous } \\
\text { land } \\
\text { (percent) }\end{array}$ & $\begin{array}{c}\text { Sedimentary, } \\
\text { clastic } \\
\text { lithology, } \\
\text { Mesozoic } \\
\text { (percent) }\end{array}$ & $\begin{array}{c}\text { Sedimentary, } \\
\text { clastic } \\
\text { (continental) } \\
\text { lithology, } \\
\text { Tertiary } \\
\text { (percent) }\end{array}$ & $\begin{array}{l}\text { Igneous or } \\
\text { metamorphic } \\
\text { lithologies } \\
\text { (percent) }\end{array}$ & $\begin{array}{c}\text { Sedimentary, } \\
\text { mixed } \\
\text { (continental } \\
\text { and marine) } \\
\text { lithology } \\
\text { (percent) }\end{array}$ & $\begin{array}{c}\text { Sedimentary, } \\
\text { carbonate } \\
\text { (marine) } \\
\text { lithology } \\
\text { (percent) }\end{array}$ & $\begin{array}{c}\text { Population } \\
\text { density } \\
\text { (people per } \\
\text { square mile) }\end{array}$ & $\begin{array}{l}\text { Road density } \\
\text { (miles per } \\
\text { square mile) }\end{array}$ \\
\hline 2.5 & 17.2 & 0.2 & 34.6 & 29.4 & 0.0 & 8.0 & 77.3 & 14.7 & 0.0 & 0.15 & 0.48 \\
\hline 3.7 & 31.2 & 0.3 & 40.2 & 17.0 & 0.0 & 2.5 & 77.4 & 20.1 & 0.0 & 0.15 & 0.34 \\
\hline 2.2 & 15.2 & 0.4 & 58.8 & 14.0 & 0.0 & 7.4 & 70.5 & 22.1 & 0.0 & 0.15 & 0.45 \\
\hline 3.0 & 18.0 & 0.2 & 47.2 & 12.4 & 0.1 & 31.5 & 43.1 & 25.0 & 0.3 & 0.15 & 1.20 \\
\hline 13.0 & 48.4 & 0.2 & 38.0 & 0.0 & 0.0 & 0.0 & 89.2 & 10.8 & 0.0 & 0.12 & 2.77 \\
\hline 1.5 & 22.3 & 0.9 & 49.6 & 18.2 & 0.0 & 3.7 & 78.4 & 17.9 & 0.0 & 0.14 & 0.26 \\
\hline 4.5 & 45.6 & 0.7 & 33.3 & 12.5 & 0.0 & 1.8 & 75.4 & 22.7 & 0.0 & 0.12 & 0.14 \\
\hline 2.5 & 51.9 & 1.0 & 39.8 & 3.1 & 0.0 & 0.1 & 93.1 & 6.9 & 0.0 & 0.12 & 0.01 \\
\hline 0.0 & 0.0 & 0.0 & 0.3 & 3.2 & 0.0 & 100.0 & 0.0 & 0.0 & 0.0 & 0.12 & 0.33 \\
\hline 1.6 & 40.7 & 0.1 & 33.5 & 11.3 & 31.5 & 48.5 & 0.0 & 14.3 & 5.7 & 0.38 & 0.85 \\
\hline 0.3 & 24.4 & 0.1 & 67.6 & 5.8 & 0.7 & 74.6 & 0.0 & 0.0 & 24.7 & 0.12 & 2.71 \\
\hline 0.1 & 41.3 & 0.1 & 47.7 & 7.6 & 52.9 & 10.9 & 0.0 & 1.8 & 34.3 & 0.08 & 1.55 \\
\hline 0.5 & 48.3 & 0.0 & 36.4 & 14.3 & 73.1 & 2.1 & 0.0 & 10.1 & 14.7 & 0.10 & 1.05 \\
\hline 0.5 & 39.2 & 0.0 & 45.6 & 11.1 & 59.9 & 18.4 & 0.0 & 7.4 & 14.3 & 0.10 & 1.21 \\
\hline 1.6 & 17.6 & 0.1 & 58.1 & 8.5 & 8.9 & 60.7 & 15.9 & 10.3 & 4.0 & 0.18 & 1.30 \\
\hline 1.1 & 37.8 & 0.0 & 41.4 & 16.7 & 68.5 & 16.0 & 0.0 & 8.3 & 7.2 & 0.09 & 0.65 \\
\hline 1.1 & 27.8 & 0.0 & 48.2 & 21.3 & 75.2 & 15.2 & 0.0 & 3.6 & 6.0 & 0.10 & 0.92 \\
\hline 0.8 & 20.3 & 0.0 & 58.2 & 16.1 & 56.6 & 36.4 & 0.0 & 2.6 & 4.4 & 0.11 & 1.18 \\
\hline 1.5 & 17.0 & 0.1 & 59.1 & 8.6 & 11.1 & 60.8 & 14.5 & 9.5 & 3.9 & 0.17 & 1.32 \\
\hline 6.6 & 47.7 & 0.3 & 26.8 & 15.2 & 0.0 & 10.9 & 58.7 & 30.3 & 0.0 & 0.12 & 0.77 \\
\hline 2.2 & 14.2 & 0.1 & 70.8 & 10.3 & 0.0 & 68.9 & 19.5 & 11.6 & 0.0 & 0.12 & 1.46 \\
\hline 0.0 & 0.1 & 0.0 & 96.4 & 2.8 & 0.2 & 99.8 & 0.0 & 0.0 & 0.0 & 0.04 & 1.07 \\
\hline 0.0 & 0.1 & 0.0 & 94.8 & 3.6 & 32.1 & 67.9 & 0.0 & 0.0 & 0.0 & 0.04 & 1.51 \\
\hline 0.0 & 1.5 & 0.0 & 94.2 & 3.8 & 21.0 & 79.0 & 0.0 & 0.0 & 0.0 & 0.04 & 1.35 \\
\hline 0.1 & 0.5 & 0.0 & 87.1 & 9.9 & 37.6 & 62.4 & 0.0 & 0.0 & 0.0 & 0.04 & 1.45 \\
\hline 0.0 & 0.0 & 0.0 & 95.4 & 4.6 & 100.0 & 0.0 & 0.0 & 0.0 & 0.0 & 0.04 & 1.08 \\
\hline 0.0 & 0.4 & 0.0 & 91.9 & 6.7 & 50.9 & 49.1 & 0.0 & 0.0 & 0.0 & 0.04 & 1.24 \\
\hline 0.7 & 8.0 & 0.1 & 75.4 & 8.0 & 14.8 & 71.8 & 7.1 & 4.5 & 1.7 & 0.52 & 1.56 \\
\hline 0.7 & 60.3 & 0.8 & 12.9 & 6.6 & 2.9 & 8.0 & 0.0 & 82.8 & 6.3 & 0.12 & 0.55 \\
\hline 1.6 & 60.3 & 2.1 & 12.2 & 6.1 & 2.9 & 10.2 & 0.0 & 81.2 & 5.7 & 0.12 & 0.61 \\
\hline 2.9 & 35.8 & 2.2 & 27.6 & 6.8 & 4.5 & 45.2 & 0.0 & 47.5 & 2.9 & 0.19 & 1.28 \\
\hline 0.4 & 65.6 & 0.3 & 11.6 & 9.0 & 0.9 & 17.0 & 0.0 & 81.2 & 0.9 & 0.12 & 0.54 \\
\hline 2.3 & 79.2 & 2.1 & 7.6 & 6.2 & 15.4 & 42.5 & 0.0 & 38.0 & 4.0 & 0.13 & 1.98 \\
\hline 3.1 & 46.9 & 1.6 & 21.5 & 6.0 & 13.7 & 56.6 & 0.0 & 28.8 & 1.0 & 0.73 & 1.32 \\
\hline 2.3 & 27.4 & 1.2 & 41.6 & 5.4 & 7.8 & 67.0 & 0.0 & 23.9 & 1.2 & 1.01 & 1.46 \\
\hline 2.9 & 0.5 & 0.6 & 63.0 & 32.5 & 11.1 & 88.9 & 0.0 & 0.0 & 0.0 & 0.27 & 1.80 \\
\hline 2.4 & 0.9 & 0.9 & 67.7 & 25.9 & 34.5 & 65.4 & 0.0 & 0.0 & 0.1 & 0.22 & 1.77 \\
\hline 2.0 & 0.7 & 0.8 & 71.3 & 22.6 & 44.7 & 55.2 & 0.0 & 0.0 & 0.1 & 0.36 & 1.87 \\
\hline 2.0 & 3.4 & 0.8 & 77.3 & 13.2 & 25.7 & 72.7 & 0.0 & 1.5 & 0.0 & 0.28 & 1.80 \\
\hline
\end{tabular}


Appendix 1-1. Watershed characteristics for the U.S. Geological Survey streamgage network in the Upper Colorado River Basin.-Continued

\begin{tabular}{|c|c|c|c|c|c|c|c|c|c|}
\hline $\begin{array}{c}\text { Site } \\
\text { number }\end{array}$ & Period of record & $\begin{array}{l}\text { Latitude } \\
\text { (decimal } \\
\text { degrees) }\end{array}$ & $\begin{array}{c}\text { Longitude } \\
\text { (decimal degrees) }\end{array}$ & $\begin{array}{c}\text { Drainage } \\
\text { area } \\
\text { (square } \\
\text { miles) }\end{array}$ & 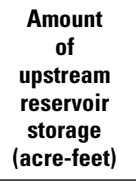 & $\begin{array}{c}\text { Mean basin } \\
\text { elevation } \\
\text { (feet) }\end{array}$ & $\begin{array}{l}\text { Mean basin } \\
\text { average } \\
\text { annual } \\
\text { precipitation } \\
\text { (inches) }\end{array}$ & $\begin{array}{c}\text { Area covered } \\
\text { by developed } \\
\text { land } \\
\text { (percent) }\end{array}$ & $\begin{array}{c}\text { Area } \\
\text { covered by } \\
\text { barren land } \\
\text { (percent) }\end{array}$ \\
\hline 09222500 & 1896-97 & 41.583289 & -110.000703 & $2,086.12$ & 46,470 & 7,510 & 14.6 & 1.1 & 2.4 \\
\hline 09223000 & 1952 to current year & 42.110494 & -110.709621 & 128.62 & 0 & 8,476 & 28.3 & 0.0 & 0.0 \\
\hline 09223385 & 2007 to current year & 41.963367 & -110.660106 & 239.92 & 42,393 & 8,177 & 24.9 & 0.2 & 0.0 \\
\hline 09224500 & $1896-1900$ & 41.583289 & -109.967369 & $2,725.16$ & 88,863 & 7,499 & 15.1 & 1.1 & 1.9 \\
\hline 09224700 & 1962 to current year & 41.546072 & -109.693475 & $2,980.53$ & 88,863 & 7,407 & 14.5 & 1.2 & 2.1 \\
\hline 09225000 & $1947-62$ & 41.379129 & -109.611529 & $3,651.87$ & 88,863 & 7,275 & 13.6 & 1.0 & 2.0 \\
\hline 09226000 & $1942-72$ & 41.006337 & -110.270988 & 56.82 & 0 & 10,318 & 30.8 & 1.1 & 9.0 \\
\hline 09226500 & $1948-70$ & 40.944393 & -110.179321 & 28.55 & 0 & 10,462 & 30.0 & 0.1 & 11.2 \\
\hline 09227000 & $1948-62$ & 40.944394 & -110.161821 & 7.22 & 0 & 9,352 & 23.2 & 0.5 & 1.5 \\
\hline 09230300 & 2007 to current year & 40.990278 & -109.654528 & 22.76 & 0 & 7,181 & 13.2 & 3.4 & 0.4 \\
\hline 09232000 & $1942-61$ & 40.886065 & -109.903485 & 42.45 & 0 & 10,065 & 27.6 & 0.4 & 6.1 \\
\hline 09232500 & $1946-61$ & 40.933292 & -109.656257 & 99.34 & 13,700 & 8,954 & 21.8 & 0.6 & 3.0 \\
\hline 09233000 & 1949-54 & 40.838844 & -109.831262 & 12.21 & 0 & 10,274 & 29.1 & 0.0 & 12.2 \\
\hline 09233500 & $1946-49$ & 40.845789 & -109.802650 & 9.25 & 0 & 10,160 & 29.0 & 0.0 & 8.4 \\
\hline 09234000 & $1946-55$ & 40.893014 & -109.592365 & 111.19 & 0 & 8,993 & 22.5 & 0.7 & 2.1 \\
\hline 09234500 & $1950-$ & 40.908293 & -109.422914 & $15,109.92$ & 562,684 & 7,431 & 13.9 & 0.8 & 1.6 \\
\hline 09234700 & $1971-76$ & 40.969682 & -109.237352 & 140.65 & 0 & 7,354 & 13.9 & 0.4 & 0.0 \\
\hline 09235000 & $1912-15$ & 40.862182 & -109.139570 & $15,412.28$ & $4,349,684$ & 7,425 & 13.9 & 0.8 & 1.6 \\
\hline 09235100 & $1986-90$ & 40.795238 & -109.091235 & 111.27 & 0 & 7,719 & 17.6 & 0.5 & 0.0 \\
\hline 09235300 & $1975-81$ & 41.014962 & -108.644831 & 195.94 & 0 & 7,364 & 12.5 & 0.4 & 0.1 \\
\hline 09237800 & $1965-73$ & 40.295815 & -106.801435 & 40.60 & 0 & 9,285 & 36.3 & 0.0 & 0.1 \\
\hline 09238000 & $1952-57$ & 40.243870 & -107.015328 & 13.45 & 0 & 8,750 & 26.3 & 0.2 & 0.3 \\
\hline 09238300 & $1972-75$ & 40.395536 & -106.649764 & 0.75 & 0 & 9,763 & 47.0 & 0.0 & 0.0 \\
\hline 09238350 & $1972-75$ & 40.429424 & -106.676710 & 6.14 & 0 & 10,071 & 52.2 & 0.0 & 0.0 \\
\hline 09238500 & $1920-22,1965-73,1978-87$ & 40.408035 & -106.786992 & 42.12 & 0 & 9,487 & 47.1 & 0.9 & 0.0 \\
\hline 09238700 & $1984-86$ & 40.473312 & -106.680044 & 0.73 & 0 & 10,074 & 52.9 & 0.0 & 0.0 \\
\hline 09238705 & $1987-95$ & 40.473590 & -106.680044 & 0.73 & 0 & 10,074 & 52.9 & 0.0 & 0.0 \\
\hline 09238710 & $1985-95$ & 40.476645 & -106.687544 & 0.96 & 0 & 10,134 & 53.0 & 0.0 & 0.0 \\
\hline 09238750 & $1985-95$ & 40.498312 & -106.692267 & 1.50 & 0 & 10,220 & 54.4 & 0.0 & 0.0 \\
\hline 09238770 & $1985-95$ & 40.493034 & -106.692545 & 2.99 & 0 & 10,165 & 54.1 & 0.0 & 0.1 \\
\hline 09238800 & 1984-94 & 40.497200 & -106.698934 & 0.03 & 0 & 9,863 & 52.4 & 0.0 & 19.4 \\
\hline 09238900 & $\begin{array}{l}1966-72,1982 \text { to current } \\
\text { year }\end{array}$ & 40.474978 & -106.786993 & 26.10 & 0 & 9,698 & 50.2 & 0.2 & 0.4 \\
\hline 09239400 & $1965-72$ & 40.493310 & -106.805327 & 6.46 & 0 & 8,715 & 39.9 & 2.0 & 0.1 \\
\hline 09239500 & $\begin{array}{l}1904-06,1909 \text { to current } \\
\text { year }\end{array}$ & 40.483588 & -106.832271 & 565.60 & 29,731 & 8,780 & 31.5 & 1.2 & 0.5 \\
\hline 09240500 & $1911-18$ & 40.755528 & -106.810046 & 63.56 & 0 & 9,763 & 46.4 & 0.0 & 7.6 \\
\hline 09240800 & $1966-73$ & 40.745251 & -106.807268 & 34.00 & 0 & 9,712 & 46.0 & 0.0 & 4.5 \\
\hline 09240900 & 1988-93, 1998-2003 & 40.743306 & -106.855325 & 123.23 & 0 & 9,517 & 43.7 & 0.0 & 5.2 \\
\hline 09241000 & $\begin{array}{l}\text { 1910-22, 1930-91, } \\
1998-2003\end{array}$ & 40.717473 & -106.915883 & 216.26 & 28,721 & 9,105 & 38.2 & 0.2 & 3.1 \\
\hline
\end{tabular}




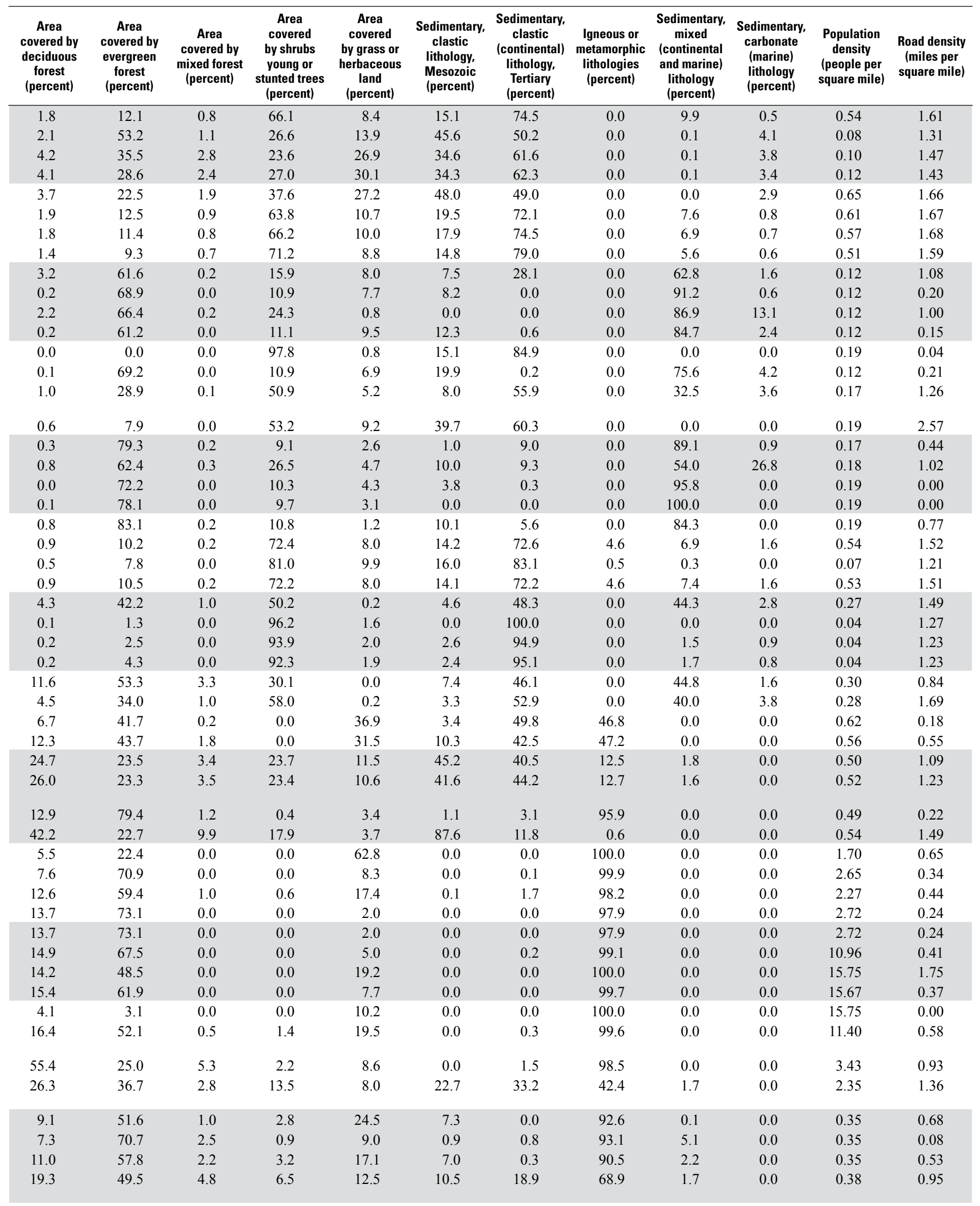


Appendix 1-1. Watershed characteristics for the U.S. Geological Survey streamgage network in the Upper Colorado River Basin.-Continued

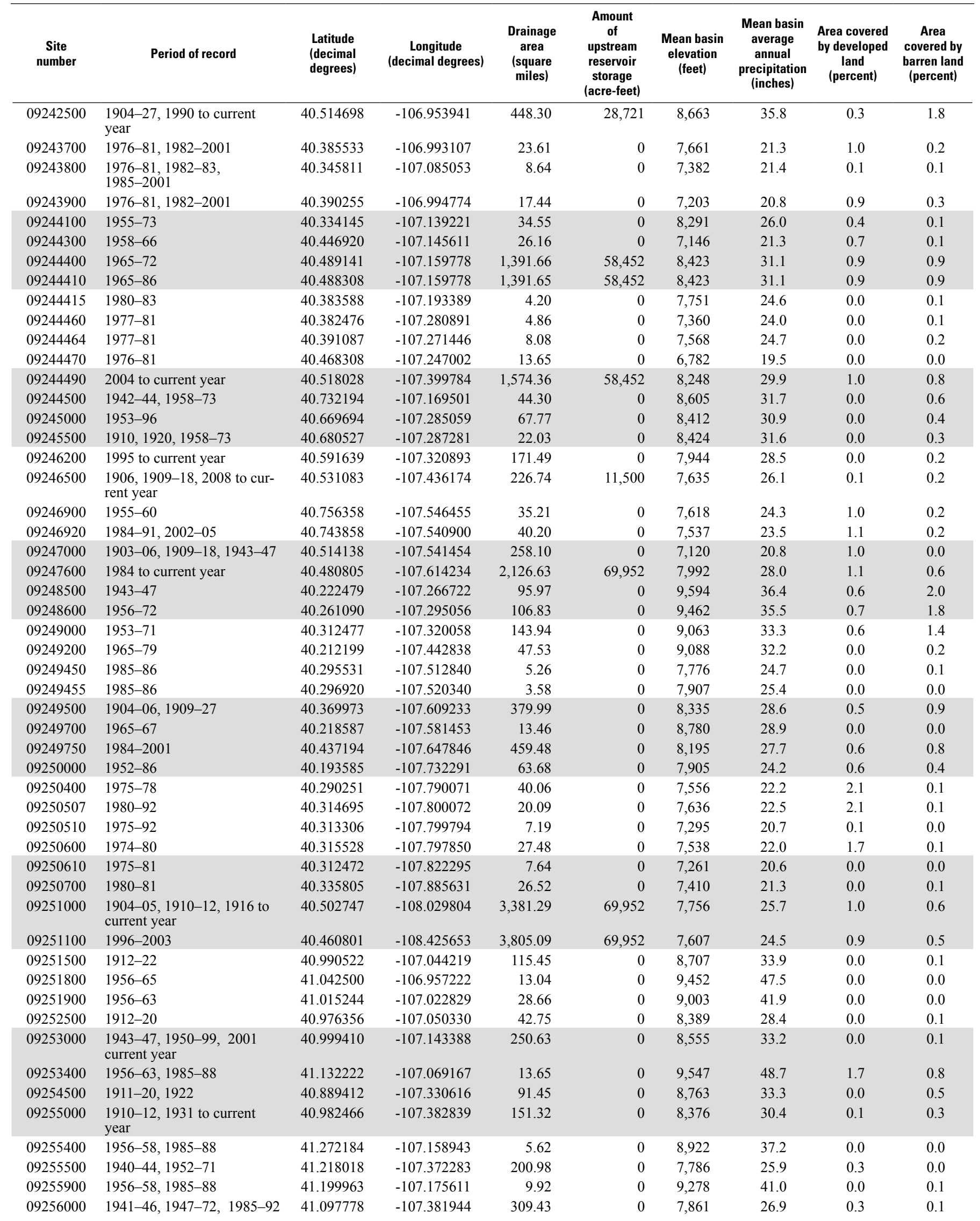




\begin{tabular}{|c|c|c|c|c|c|c|c|c|c|c|c|}
\hline $\begin{array}{c}\text { Area } \\
\text { covered by } \\
\text { deciduous } \\
\text { forest } \\
\text { (percent) }\end{array}$ & $\begin{array}{c}\text { Area } \\
\text { covered by } \\
\text { evergreen } \\
\text { forest } \\
\text { (percent) }\end{array}$ & $\begin{array}{c}\text { Area } \\
\text { covered by } \\
\text { mixed forest } \\
\text { (percent) }\end{array}$ & $\begin{array}{c}\text { Area } \\
\text { covered } \\
\text { by shrubs } \\
\text { young or } \\
\text { stunted trees } \\
\text { (percent) }\end{array}$ & $\begin{array}{c}\text { Area } \\
\text { covered } \\
\text { by grass or } \\
\text { herbaceous } \\
\text { land } \\
\text { (percent) }\end{array}$ & $\begin{array}{c}\text { Sedimentary, } \\
\text { clastic } \\
\text { lithology, } \\
\text { Mesozoic } \\
\text { (percent) }\end{array}$ & $\begin{array}{c}\text { Sedimentary, } \\
\text { clastic } \\
\text { (continental) } \\
\text { lithology, } \\
\text { Tertiary } \\
\text { (percent) }\end{array}$ & $\begin{array}{l}\text { Igneous or } \\
\text { metamorphic } \\
\text { lithologies } \\
\text { (percent) }\end{array}$ & $\begin{array}{c}\text { Sedimentary, } \\
\text { mixed } \\
\text { (continental } \\
\text { and marine) } \\
\text { lithology } \\
\text { (percent) }\end{array}$ & $\begin{array}{c}\text { Sedimentary, } \\
\text { carbonate } \\
\text { (marine) } \\
\text { lithology } \\
\text { (percent) }\end{array}$ & $\begin{array}{l}\text { Population } \\
\text { density } \\
\text { (people per } \\
\text { square mile) }\end{array}$ & $\begin{array}{c}\text { Road density } \\
\text { (miles per } \\
\text { square mile) }\end{array}$ \\
\hline 28.3 & 35.6 & 4.1 & 13.2 & 9.2 & 22.9 & 19.2 & 55.9 & 2.0 & 0.0 & 0.49 & 0.90 \\
\hline 58.0 & 5.0 & 2.0 & 29.7 & 0.1 & 100.0 & 0.0 & 0.0 & 0.0 & 0.0 & 1.34 & 1.16 \\
\hline 32.9 & 5.3 & 0.0 & 54.3 & 0.1 & 100.0 & 0.0 & 0.0 & 0.0 & 0.0 & 1.19 & 1.28 \\
\hline 47.4 & 16.1 & 7.5 & 18.5 & 4.1 & 77.2 & 14.3 & 8.4 & 0.0 & 0.0 & 0.39 & 0.93 \\
\hline 41.2 & 3.8 & 0.0 & 45.3 & 0.2 & 100.0 & 0.0 & 0.0 & 0.0 & 0.0 & 0.08 & 1.71 \\
\hline 30.5 & 29.1 & 2.9 & 19.0 & 6.9 & 37.1 & 23.6 & 37.8 & 1.4 & 0.0 & 1.80 & 1.26 \\
\hline 30.5 & 29.1 & 2.9 & 19.0 & 6.9 & 37.1 & 23.6 & 37.8 & 1.4 & 0.0 & 1.80 & 1.26 \\
\hline 82.3 & 1.2 & 0.0 & 13.6 & 0.3 & 100.0 & 0.0 & 0.0 & 0.0 & 0.0 & 0.08 & 1.64 \\
\hline 42.0 & 21.6 & 5.9 & 23.3 & 5.3 & 72.9 & 24.9 & 2.2 & 0.0 & 0.0 & 0.12 & 0.55 \\
\hline 48.5 & 16.0 & 4.7 & 24.3 & 4.3 & 76.9 & 21.7 & 1.5 & 0.0 & 0.0 & 0.12 & 0.51 \\
\hline 59.0 & 11.4 & 3.2 & 12.9 & 10.1 & 17.6 & 81.8 & 0.6 & 0.0 & 0.0 & 0.11 & 0.22 \\
\hline 43.0 & 10.4 & 2.8 & 36.4 & 3.8 & 78.7 & 20.5 & 0.8 & 0.0 & 0.0 & 0.12 & 0.80 \\
\hline 33.5 & 8.5 & 2.1 & 47.1 & 2.9 & 72.7 & 26.7 & 0.6 & 0.0 & 0.0 & 0.17 & 1.06 \\
\hline 30.9 & 10.8 & 1.9 & 49.7 & 1.1 & 0.0 & 99.7 & 0.3 & 0.0 & 0.0 & 0.08 & 0.84 \\
\hline 27.9 & 9.9 & 1.7 & 54.1 & 1.0 & 0.0 & 99.7 & 0.3 & 0.0 & 0.0 & 0.08 & 0.85 \\
\hline 16.9 & 4.2 & 0.6 & 69.9 & 0.8 & 2.8 & 96.8 & 0.4 & 0.0 & 0.0 & 1.93 & 1.46 \\
\hline 27.9 & 20.8 & 2.2 & 33.1 & 5.0 & 42.7 & 31.4 & 25.0 & 0.9 & 0.0 & 2.08 & 1.35 \\
\hline 35.4 & 40.3 & 3.4 & 2.8 & 13.1 & 59.6 & 26.2 & 14.2 & 0.0 & 0.0 & 0.18 & 0.33 \\
\hline 39.6 & 36.5 & 3.5 & 3.4 & 12.2 & 58.3 & 28.2 & 13.5 & 0.0 & 0.0 & 0.17 & 0.34 \\
\hline 44.4 & 8.2 & 0.0 & 38.7 & 1.0 & 100.0 & 0.0 & 0.0 & 0.0 & 0.0 & 0.09 & 1.39 \\
\hline 47.9 & 8.6 & 0.0 & 36.3 & 1.6 & 100.0 & 0.0 & 0.0 & 0.0 & 0.0 & 0.08 & 2.08 \\
\hline 23.5 & 4.9 & 0.0 & 70.5 & 0.0 & 100.0 & 0.0 & 0.0 & 0.0 & 0.0 & 0.04 & 2.71 \\
\hline 41.2 & 7.6 & 0.0 & 45.6 & 1.2 & 100.0 & 0.0 & 0.0 & 0.0 & 0.0 & 0.07 & 2.29 \\
\hline 19.2 & 9.7 & 0.0 & 70.2 & 0.3 & 100.0 & 0.0 & 0.0 & 0.0 & 0.0 & 0.04 & 2.09 \\
\hline 31.2 & 5.3 & 0.0 & 60.6 & 0.8 & 100.0 & 0.0 & 0.0 & 0.0 & 0.0 & 0.04 & 2.00 \\
\hline 27.2 & 16.7 & 1.8 & 41.2 & 4.0 & 52.6 & 30.2 & 16.4 & 0.6 & 0.2 & 1.38 & 1.33 \\
\hline 24.3 & 15.8 & 1.6 & 46.3 & 3.6 & 47.8 & 36.4 & 14.6 & 0.7 & 0.5 & 1.23 & 1.37 \\
\hline 32.6 & 44.0 & 7.4 & 6.6 & 6.9 & 11.5 & 31.7 & 56.1 & 0.6 & 0.0 & 0.13 & 0.89 \\
\hline 5.0 & 74.9 & 2.0 & 0.2 & 17.3 & 0.0 & 0.0 & 100.0 & 0.0 & 0.0 & 0.12 & 0.58 \\
\hline 19.1 & 60.1 & 7.6 & 1.8 & 11.0 & 0.0 & 1.9 & 97.9 & 0.1 & 0.0 & 0.12 & 0.56 \\
\hline 41.0 & 23.0 & 6.4 & 23.8 & 3.1 & 27.8 & 61.2 & 11.0 & 0.0 & 0.0 & 0.12 & 0.56 \\
\hline 33.7 & 37.3 & 6.7 & 12.7 & 6.1 & 11.5 & 38.1 & 49.4 & 1.0 & 0.0 & 0.12 & 0.80 \\
\hline 2.9 & 71.8 & 0.0 & 1.5 & 20.7 & 0.0 & 0.0 & 78.0 & 21.9 & 0.0 & 0.12 & 1.14 \\
\hline 35.8 & 32.9 & 8.6 & 14.6 & 6.4 & 17.5 & 78.5 & 4.1 & 0.0 & 0.0 & 0.11 & 0.86 \\
\hline 37.1 & 25.8 & 6.6 & 24.1 & 4.1 & 15.1 & 79.8 & 5.1 & 0.0 & 0.0 & 0.10 & 0.99 \\
\hline 1.9 & 86.1 & 0.1 & 6.5 & 5.5 & 0.0 & 0.0 & 65.4 & 34.6 & 0.0 & 0.12 & 1.42 \\
\hline 5.2 & 13.8 & 0.0 & 74.5 & 3.0 & 9.8 & 77.0 & 11.5 & 1.6 & 0.0 & 0.14 & 1.90 \\
\hline 3.3 & 90.6 & 0.0 & 0.7 & 5.2 & 0.0 & 0.0 & 89.9 & 10.1 & 0.0 & 0.12 & 0.92 \\
\hline 11.8 & 20.8 & 0.9 & 59.7 & 3.3 & 14.6 & 68.5 & 15.5 & 1.4 & 0.1 & 0.14 & 1.64 \\
\hline
\end{tabular}


Appendix 1-1. Watershed characteristics for the U.S. Geological Survey streamgage network in the Upper Colorado River Basin.-Continued

\begin{tabular}{|c|c|c|c|c|c|c|c|c|c|}
\hline $\begin{array}{c}\text { Site } \\
\text { number }\end{array}$ & Period of record & $\begin{array}{l}\text { Latitude } \\
\text { (decimal } \\
\text { degrees) }\end{array}$ & $\begin{array}{c}\text { Longitude } \\
\text { (decimal degrees) }\end{array}$ & $\begin{array}{c}\text { Drainage } \\
\text { area } \\
\text { (square } \\
\text { miles) }\end{array}$ & $\begin{array}{c}\begin{array}{c}\text { Amount } \\
\text { of }\end{array} \\
\text { upstream } \\
\text { reservoir } \\
\text { storage } \\
\text { (acre-feet) }\end{array}$ & $\begin{array}{l}\text { Mean basin } \\
\text { elevation } \\
\text { (feet) }\end{array}$ & $\begin{array}{l}\text { Mean basin } \\
\text { average } \\
\text { annual } \\
\text { precipitation } \\
\text { (inches) }\end{array}$ & $\begin{array}{c}\text { Area covered } \\
\text { by developed } \\
\text { Iand } \\
\text { (percent) }\end{array}$ & $\begin{array}{c}\text { Area } \\
\text { covered by } \\
\text { barren land } \\
\text { (percent) }\end{array}$ \\
\hline 09256500 & $1914-16,1918-22$ & 41.024687 & -107.444507 & 352.18 & 0 & 7,784 & 26.1 & 0.4 & 0.0 \\
\hline 09257000 & $1910-23,1938-98$ & 41.028298 & -107.549233 & $1,069.99$ & 0 & 7,996 & 27.8 & 0.3 & 0.1 \\
\hline 09258000 & $1953-93$ & 40.915522 & -107.521732 & 24.62 & 0 & 8,066 & 28.5 & 0.0 & 0.3 \\
\hline 09259700 & $1961-68$ & 41.003020 & -107.920356 & $3,011.69$ & 0 & 7,246 & 18.0 & 0.3 & 0.6 \\
\hline 09259950 & $1950-69$ & 40.607467 & -108.337039 & $3,688.10$ & 0 & 7,116 & 17.1 & 0.3 & 0.6 \\
\hline 09259990 & 1987-91 & 40.619967 & -108.368985 & 239.29 & 0 & 6,548 & 12.8 & 0.0 & 0.0 \\
\hline 09260000 & 1904,1921 to current year & 40.547189 & -108.424265 & $4,040.79$ & 0 & 7,060 & 16.7 & 0.3 & 0.6 \\
\hline 09260050 & $\begin{array}{l}1982-94,1996 \text { to current } \\
\text { year }\end{array}$ & 40.451634 & -108.525101 & $7,936.43$ & 69,952 & 7,313 & 20.4 & 0.6 & 0.6 \\
\hline 09261700 & 1979 to current year & 40.588848 & -109.465414 & 77.28 & 6,249 & 8,318 & 22.0 & 2.1 & 1.3 \\
\hline 09262500 & $1949-55$ & 40.758291 & -109.534029 & 9.24 & 0 & 9,287 & 26.7 & 0.5 & 0.0 \\
\hline 09263000 & $1946-52$ & 40.716070 & -109.505694 & 29.05 & 0 & 9,251 & 27.0 & 0.8 & 0.0 \\
\hline 09263500 & $1940-65$ & 40.408573 & -109.340963 & 259.01 & 32,249 & 7,276 & 17.4 & 1.5 & 2.0 \\
\hline 09264000 & $1944-54$ & 40.733290 & -109.678479 & 26.72 & 0 & 9,932 & 28.9 & 2.1 & 0.9 \\
\hline 09264500 & $1944-55$ & 40.733290 & -109.703480 & 20.39 & 0 & 10,458 & 31.8 & 0.7 & 10.3 \\
\hline 09265000 & $1946-69$ & 40.743290 & -109.622366 & 11.73 & 6,249 & 9,637 & 28.0 & 0.6 & 0.0 \\
\hline 09265300 & $1965-75$ & 40.679679 & -109.660978 & 56.11 & 0 & 10,015 & 29.6 & 1.4 & 4.2 \\
\hline 09265500 & $1941-45$ & 40.588847 & -109.622919 & 100.34 & 0 & 9,477 & 27.3 & 1.1 & 2.4 \\
\hline 09266000 & $1944-45,1954-55$ & 40.586069 & -109.622919 & 100.42 & 0 & 9,475 & 27.3 & 1.1 & 2.4 \\
\hline 09266500 & $\begin{array}{l}1911-12,1914-17,1919 \text { to } \\
\text { current year }\end{array}$ & 40.577458 & -109.622086 & 101.44 & 0 & 9,453 & 27.2 & 1.1 & 2.5 \\
\hline 09271000 & $1900-04,1939-65$ & 40.517181 & -109.596529 & 238.52 & 0 & 9,141 & 25.8 & 1.0 & 3.0 \\
\hline 09271400 & $2000-03$ & 40.433572 & -109.466246 & 335.47 & 38,170 & 8,189 & 21.3 & 2.9 & 3.3 \\
\hline 09271450 & $2000-03$ & 40.398017 & -109.429577 & 368.70 & 38,170 & 7,930 & 20.1 & 3.3 & 3.2 \\
\hline 09271500 & $1947-83$ & 40.374684 & -109.408188 & 379.62 & 38,170 & 7,851 & 19.8 & 3.4 & 3.2 \\
\hline 09271550 & $1991-2002$ & 40.358018 & -109.387631 & 380.79 & 38,170 & 7,841 & 19.7 & 3.4 & 3.2 \\
\hline 09272400 & 2009 to current year & 40.084686 & -109.676805 & $26,801.50$ & $4,501,905$ & 7,312 & 15.8 & 0.7 & 1.4 \\
\hline 09273000 & $1930-33,1935-54$ & 40.624945 & -110.889613 & 37.38 & 0 & 10,179 & 39.9 & 0.7 & 13.2 \\
\hline 09273200 & $1965-68$ & 40.622168 & -110.892390 & 41.32 & 0 & 10,114 & 39.6 & 0.7 & 12.4 \\
\hline 09273500 & $1950-68$ & 40.536055 & -110.867387 & 7.96 & 0 & 9,955 & 35.8 & 0.0 & 15.3 \\
\hline 09274000 & $1922-23,1929-30,1946-63$ & 40.533278 & -110.867387 & 79.92 & 0 & 9,835 & 37.1 & 0.5 & 9.8 \\
\hline 09274900 & 1989-94 & 40.450223 & -111.004332 & 37.05 & 0 & 9,216 & 32.1 & 0.6 & 0.1 \\
\hline 09275000 & $1950-68,1974-81$ & 40.448556 & -110.975720 & 43.81 & 0 & 9,149 & 31.6 & 0.5 & 0.1 \\
\hline 09275500 & $1945-94$ & 40.450223 & -110.884330 & 61.56 & 0 & 8,860 & 29.3 & 0.4 & 0.1 \\
\hline 09276000 & $1946-84$ & 40.471056 & -110.918775 & 10.70 & 0 & 9,159 & 31.7 & 2.7 & 0.2 \\
\hline 09276500 & $1922-23$ & 40.452723 & -110.882664 & 19.47 & 0 & 9,119 & 30.8 & 2.2 & 0.3 \\
\hline 09276600 & $1990-2003$ & 40.461612 & -110.836830 & 89.46 & 0 & 8,844 & 28.9 & 0.9 & 0.2 \\
\hline 09277000 & $1953-61$ & 40.415225 & -110.782662 & 236.54 & 0 & 9,101 & 30.6 & 0.6 & 3.9 \\
\hline 09277500 & 1918 to current year & 40.300230 & -110.602381 & 356.67 & 0 & 8,707 & 26.9 & 0.8 & 3.0 \\
\hline 09277501 & $1919-67$ & 40.300230 & -110.602381 & 356.67 & 0 & 8,707 & 26.9 & 0.8 & 3.0 \\
\hline 09277800 & $1965-84,1988-94$ & 40.557445 & -110.697941 & 99.07 & 0 & 10,368 & 37.4 & 0.0 & 16.1 \\
\hline
\end{tabular}




\begin{tabular}{|c|c|c|c|c|c|c|c|c|c|c|c|}
\hline $\begin{array}{c}\text { Area } \\
\text { covered by } \\
\text { deciduous } \\
\text { forest } \\
\text { (percent) }\end{array}$ & $\begin{array}{c}\text { Area } \\
\text { covered by } \\
\text { evergreen } \\
\text { forest } \\
\text { (percent) }\end{array}$ & $\begin{array}{c}\text { Area } \\
\text { covered by } \\
\text { mixed forest } \\
\text { (percent) }\end{array}$ & $\begin{array}{c}\text { Area } \\
\text { covered } \\
\text { by shrubs } \\
\text { young or } \\
\text { stunted trees } \\
\text { (percent) }\end{array}$ & $\begin{array}{c}\text { Area } \\
\text { covered } \\
\text { by grass or } \\
\text { herbaceous } \\
\text { land } \\
\text { (percent) }\end{array}$ & $\begin{array}{l}\text { Sedimentary, } \\
\text { clastic } \\
\text { lithology, } \\
\text { Mesozoic } \\
\text { (percent) }\end{array}$ & $\begin{array}{c}\text { Sedimentary, } \\
\text { clastic } \\
\text { (continental) } \\
\text { lithology, } \\
\text { Tertiary } \\
\text { (percent) }\end{array}$ & $\begin{array}{l}\text { Igneous or } \\
\text { metamorphic } \\
\text { lithologies } \\
\text { (percent) }\end{array}$ & $\begin{array}{c}\text { Sedimentary, } \\
\text { mixed } \\
\text { (continental } \\
\text { and marine) } \\
\text { lithology } \\
\text { (percent) }\end{array}$ & $\begin{array}{c}\text { Sedimentary, } \\
\text { carbonate } \\
\text { (marine) } \\
\text { lithology } \\
\text { (percent) }\end{array}$ & $\begin{array}{l}\text { Population } \\
\text { density } \\
\text { (people per } \\
\text { square mile) }\end{array}$ & $\begin{array}{l}\text { Road density } \\
\text { (miles per } \\
\text { square mile) }\end{array}$ \\
\hline 12.1 & 18.7 & 0.8 & 60.4 & 3.1 & 13.8 & 71.3 & 13.6 & 1.2 & 0.1 & 0.14 & 1.68 \\
\hline 22.4 & 23.6 & 3.2 & 42.0 & 4.0 & 17.8 & 60.1 & 20.6 & 1.4 & 0.0 & 0.12 & 1.23 \\
\hline 29.9 & 26.3 & 4.2 & 36.8 & 0.6 & 0.0 & 99.1 & 0.9 & 0.0 & 0.0 & 0.08 & 1.65 \\
\hline 8.2 & 8.9 & 1.2 & 76.1 & 2.0 & 16.6 & 75.0 & 7.3 & 0.8 & 0.0 & 0.11 & 1.21 \\
\hline 6.7 & 7.5 & 1.0 & 79.8 & 1.9 & 14.3 & 78.8 & 6.0 & 0.7 & 0.0 & 0.09 & 1.23 \\
\hline 0.0 & 2.0 & 0.0 & 95.9 & 2.0 & 1.8 & 98.2 & 0.0 & 0.0 & 0.0 & 0.04 & 1.01 \\
\hline 6.1 & 7.4 & 0.9 & 80.8 & 1.8 & 13.1 & 80.1 & 5.5 & 1.0 & 0.1 & 0.09 & 1.22 \\
\hline 14.8 & 11.8 & 1.2 & 64.0 & 2.7 & 30.1 & 58.7 & 9.8 & 0.9 & 0.5 & 0.64 & 1.29 \\
\hline 9.8 & 52.5 & 1.1 & 29.6 & 1.4 & 7.7 & 39.7 & 0.0 & 14.4 & 38.2 & 0.38 & 1.75 \\
\hline 0.1 & 70.3 & 0.3 & 13.8 & 7.5 & 4.4 & 37.2 & 0.0 & 58.4 & 0.0 & 0.35 & 1.25 \\
\hline 1.1 & 79.6 & 0.7 & 9.1 & 5.7 & 1.4 & 40.0 & 0.0 & 54.3 & 4.2 & 0.35 & 1.34 \\
\hline 5.9 & 38.6 & 0.6 & 47.0 & 1.1 & 42.3 & 27.8 & 0.0 & 10.4 & 19.4 & 0.44 & 1.78 \\
\hline 0.0 & 70.8 & 0.0 & 10.9 & 9.4 & 0.0 & 44.8 & 0.0 & 55.2 & 0.0 & 0.35 & 1.84 \\
\hline 0.0 & 65.1 & 0.0 & 12.1 & 8.4 & 0.0 & 0.5 & 0.0 & 99.5 & 0.0 & 0.35 & 0.24 \\
\hline 0.0 & 77.7 & 0.1 & 5.7 & 7.0 & 6.8 & 56.5 & 0.0 & 36.7 & 0.0 & 0.35 & 1.43 \\
\hline 0.1 & 72.5 & 0.2 & 9.9 & 7.7 & 0.0 & 30.7 & 0.0 & 69.3 & 0.0 & 0.35 & 1.03 \\
\hline 4.1 & 74.0 & 2.1 & 9.4 & 4.5 & 0.4 & 41.7 & 0.0 & 47.4 & 10.6 & 0.35 & 0.87 \\
\hline 4.1 & 74.0 & 2.1 & 9.4 & 4.5 & 0.4 & 41.7 & 0.0 & 47.3 & 10.6 & 0.35 & 0.87 \\
\hline 4.0 & 73.8 & 2.0 & 9.7 & 4.4 & 0.4 & 41.4 & 0.0 & 46.8 & 11.4 & 0.35 & 0.86 \\
\hline 4.6 & 66.7 & 1.6 & 16.0 & 4.7 & 10.2 & 28.4 & 0.0 & 44.9 & 16.6 & 0.35 & 1.00 \\
\hline 3.3 & 52.9 & 1.2 & 24.6 & 3.4 & 31.9 & 24.4 & 0.0 & 31.9 & 11.8 & 5.66 & 1.67 \\
\hline 3.0 & 48.3 & 1.1 & 26.5 & 3.1 & 37.3 & 22.9 & 0.0 & 29.0 & 10.7 & 6.18 & 1.83 \\
\hline 2.9 & 46.9 & 1.0 & 26.9 & 3.0 & 38.8 & 22.6 & 0.0 & 28.2 & 10.4 & 6.10 & 1.86 \\
\hline 2.9 & 46.8 & 1.0 & 26.9 & 3.0 & 38.8 & 22.7 & 0.0 & 28.1 & 10.4 & 6.08 & 1.86 \\
\hline 5.1 & 12.4 & 0.5 & 69.2 & 5.6 & 19.5 & 65.6 & 5.5 & 6.3 & 3.0 & 0.61 & 1.44 \\
\hline 0.5 & 73.4 & 0.5 & 5.5 & 4.4 & 0.0 & 0.0 & 0.0 & 100.0 & 0.0 & 0.08 & 0.93 \\
\hline 0.5 & 73.3 & 0.6 & 6.8 & 4.1 & 0.0 & 0.0 & 0.0 & 100.0 & 0.0 & 0.07 & 1.13 \\
\hline 3.5 & 66.7 & 1.9 & 8.8 & 3.5 & 8.2 & 0.8 & 0.0 & 84.7 & 6.2 & 0.08 & 0.54 \\
\hline 3.4 & 71.4 & 1.4 & 9.5 & 2.9 & 1.7 & 1.9 & 0.0 & 88.8 & 7.5 & 0.07 & 1.09 \\
\hline 42.4 & 32.8 & 5.9 & 17.9 & 0.2 & 42.9 & 57.1 & 0.0 & 0.0 & 0.0 & 0.01 & 1.50 \\
\hline 44.6 & 31.8 & 5.7 & 17.1 & 0.2 & 48.6 & 51.4 & 0.0 & 0.0 & 0.0 & 0.01 & 1.39 \\
\hline 43.5 & 28.1 & 4.2 & 23.4 & 0.2 & 62.1 & 37.9 & 0.0 & 0.0 & 0.0 & 0.01 & 1.30 \\
\hline 35.2 & 42.2 & 5.1 & 14.2 & 0.1 & 1.0 & 42.5 & 0.0 & 19.5 & 37.0 & 0.02 & 3.22 \\
\hline 31.7 & 42.2 & 4.3 & 18.7 & 0.4 & 3.7 & 26.2 & 0.0 & 17.5 & 52.6 & 0.04 & 2.62 \\
\hline 39.9 & 30.5 & 3.9 & 24.3 & 0.3 & 47.9 & 31.8 & 0.0 & 4.0 & 16.4 & 0.02 & 1.50 \\
\hline 22.8 & 45.1 & 2.3 & 21.6 & 2.5 & 29.9 & 14.8 & 0.0 & 33.9 & 21.4 & 0.05 & 1.25 \\
\hline 20.5 & 44.9 & 1.9 & 24.1 & 2.0 & 32.6 & 25.8 & 0.0 & 24.2 & 17.4 & 0.06 & 1.26 \\
\hline 20.5 & 44.9 & 1.9 & 24.1 & 2.0 & 32.6 & 25.8 & 0.0 & 24.2 & 17.4 & 0.06 & 1.26 \\
\hline 0.3 & 67.1 & 0.6 & 8.0 & 5.3 & 0.1 & 0.0 & 0.0 & 99.9 & 0.0 & 0.08 & 0.01 \\
\hline
\end{tabular}


Appendix 1-1. Watershed characteristics for the U.S. Geological Survey streamgage network in the Upper Colorado River Basin.-Continued

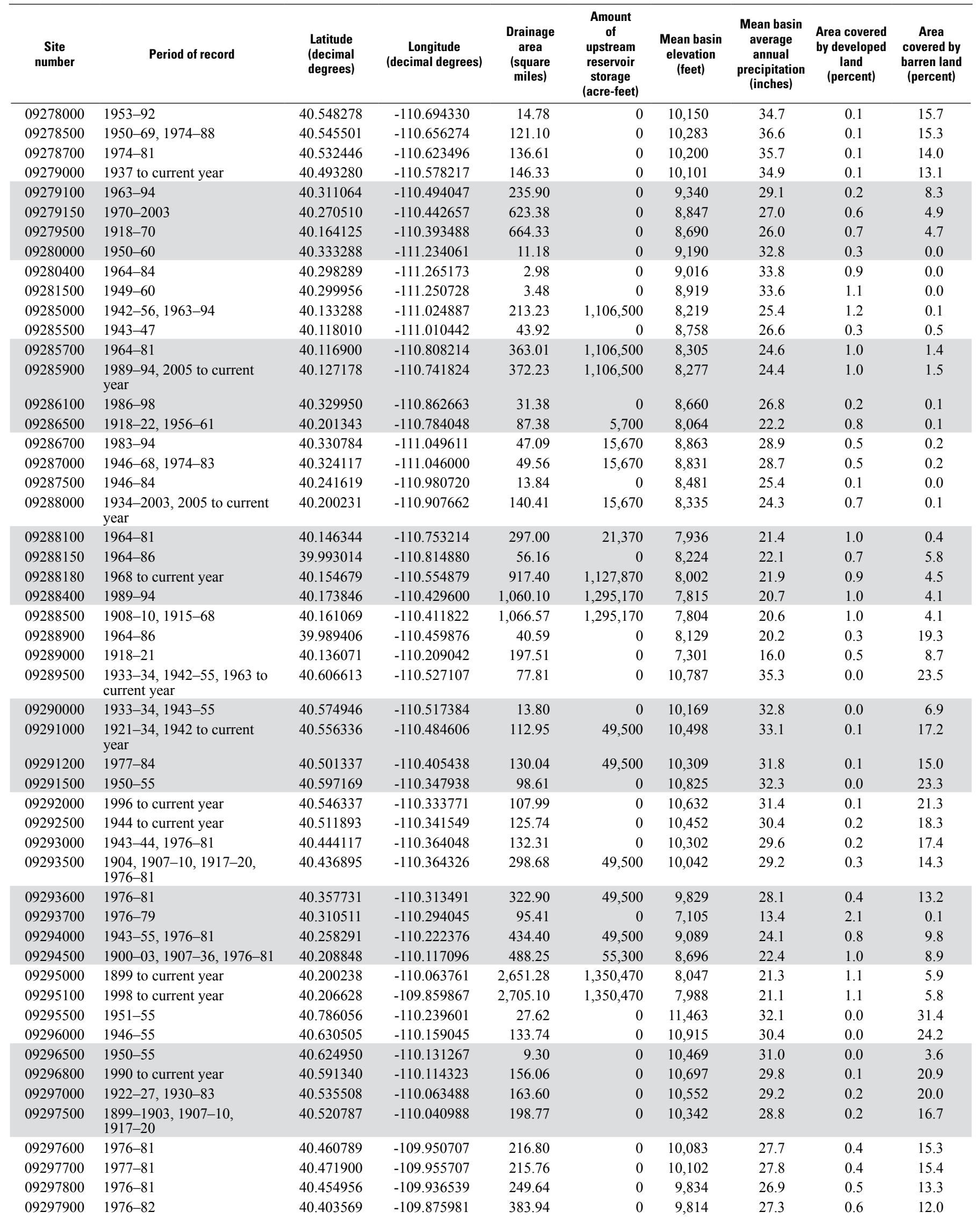




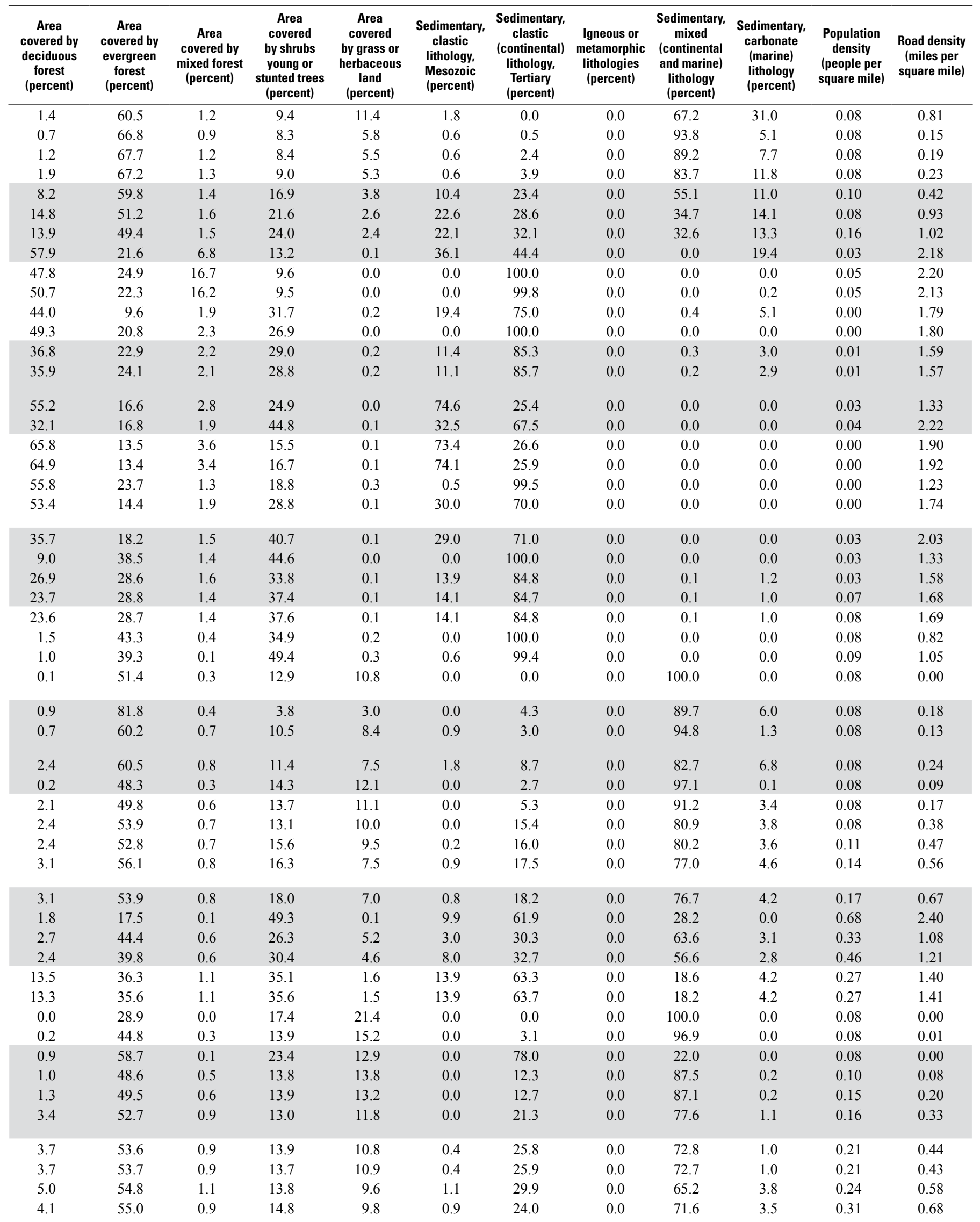


Appendix 1-1. Watershed characteristics for the U.S. Geological Survey streamgage network in the Upper Colorado River Basin.-Continued

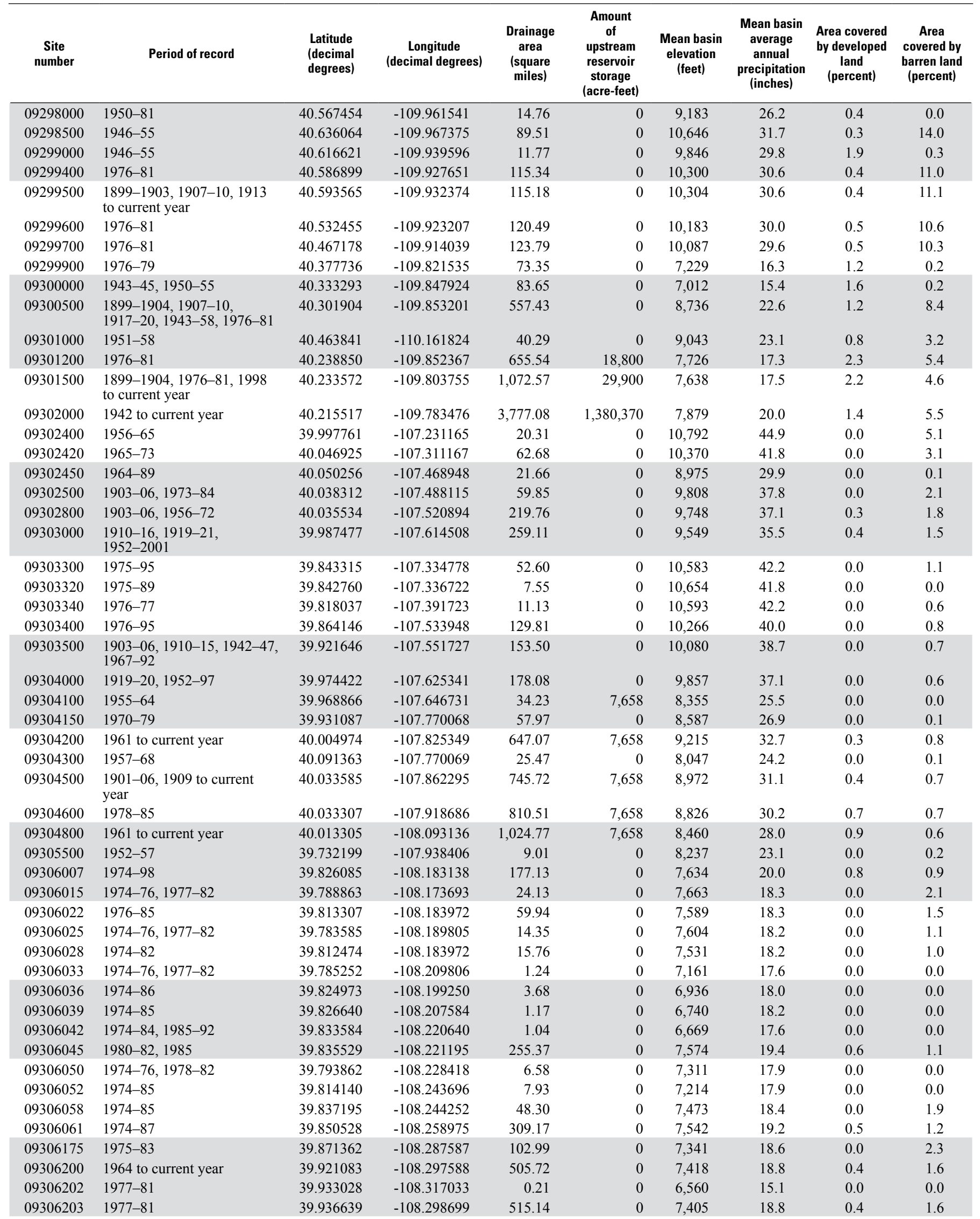




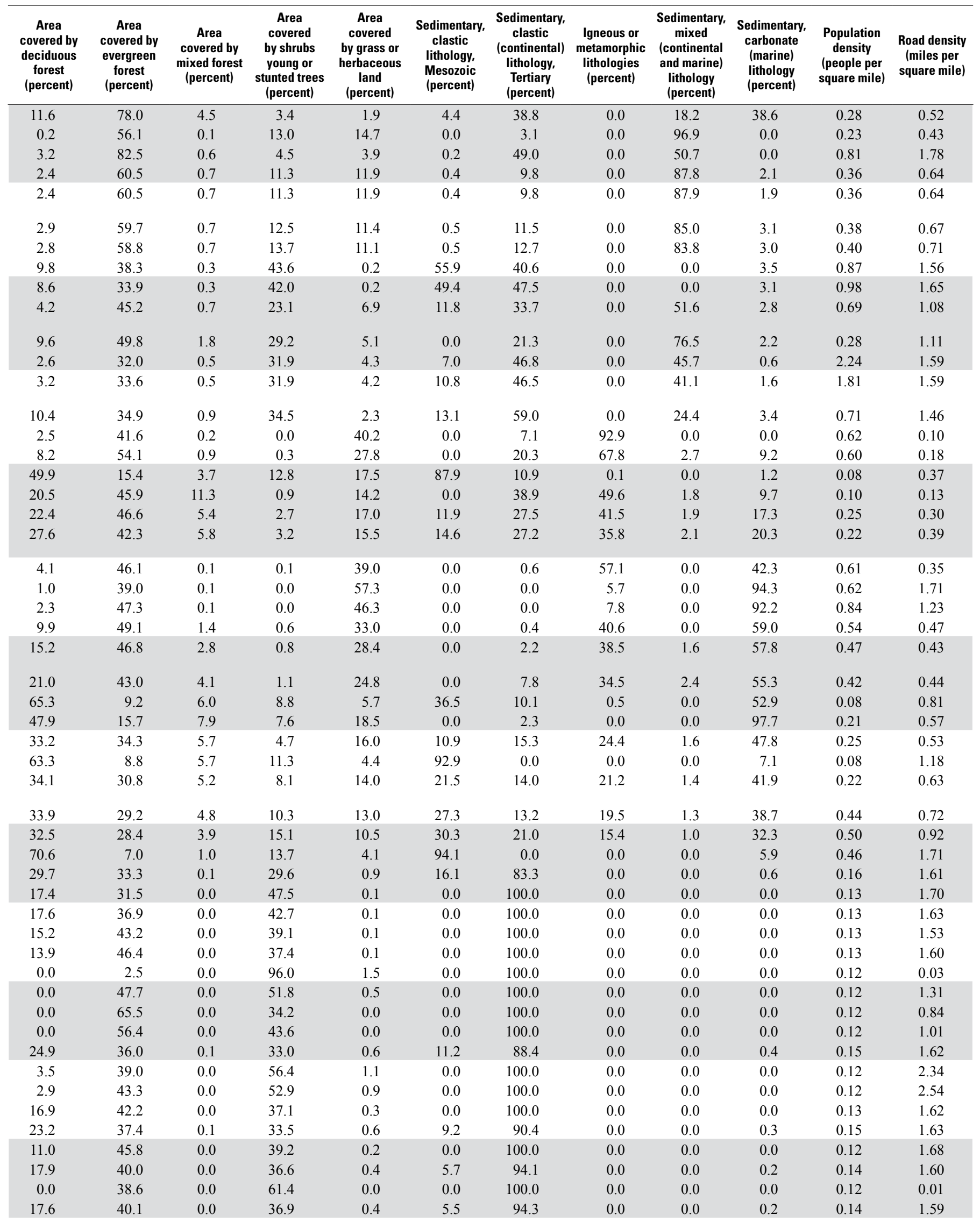


Appendix 1-1. Watershed characteristics for the U.S. Geological Survey streamgage network in the Upper Colorado River Basin.-Continued

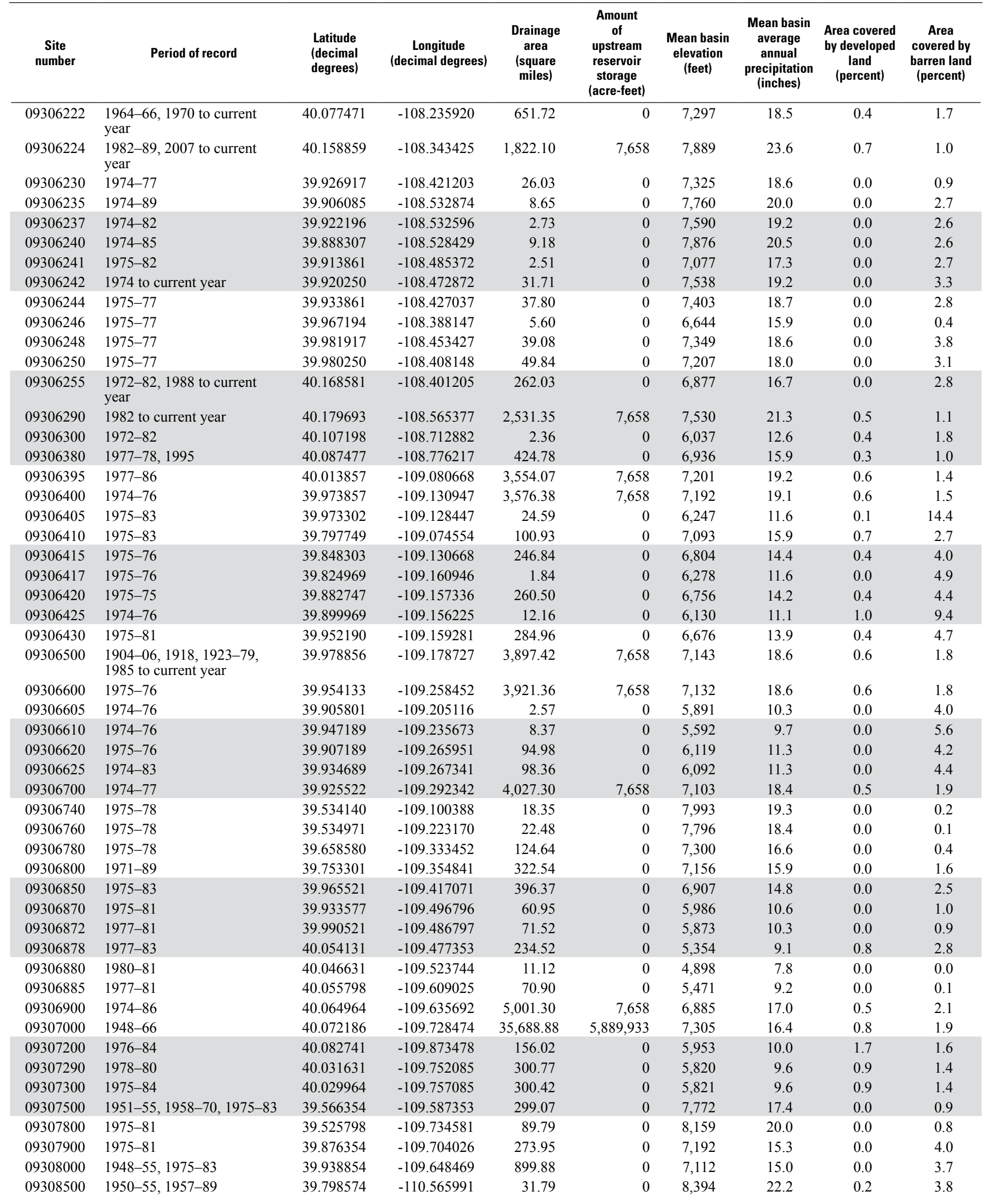




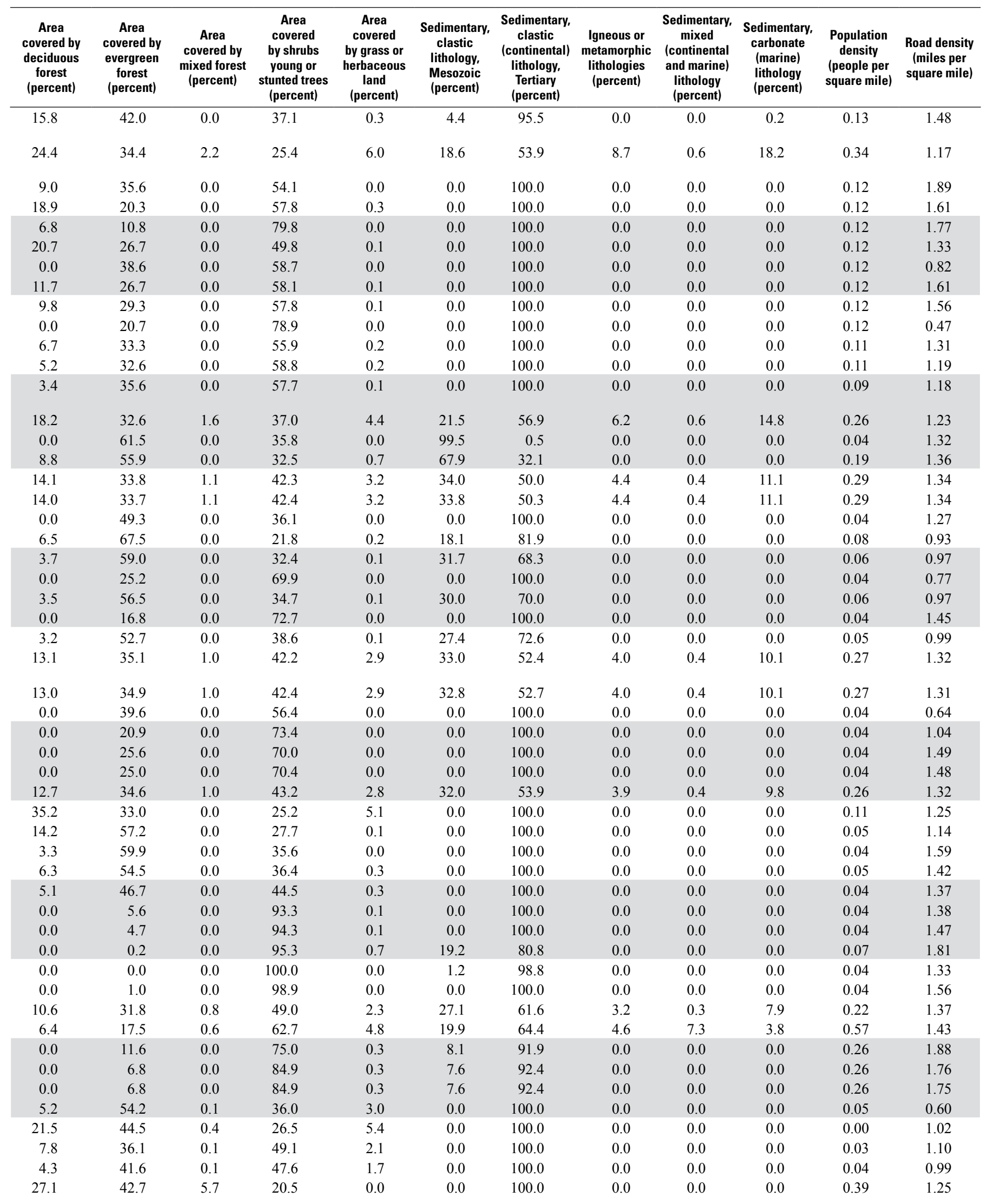


Appendix 1-1. Watershed characteristics for the U.S. Geological Survey streamgage network in the Upper Colorado River Basin.-Continued

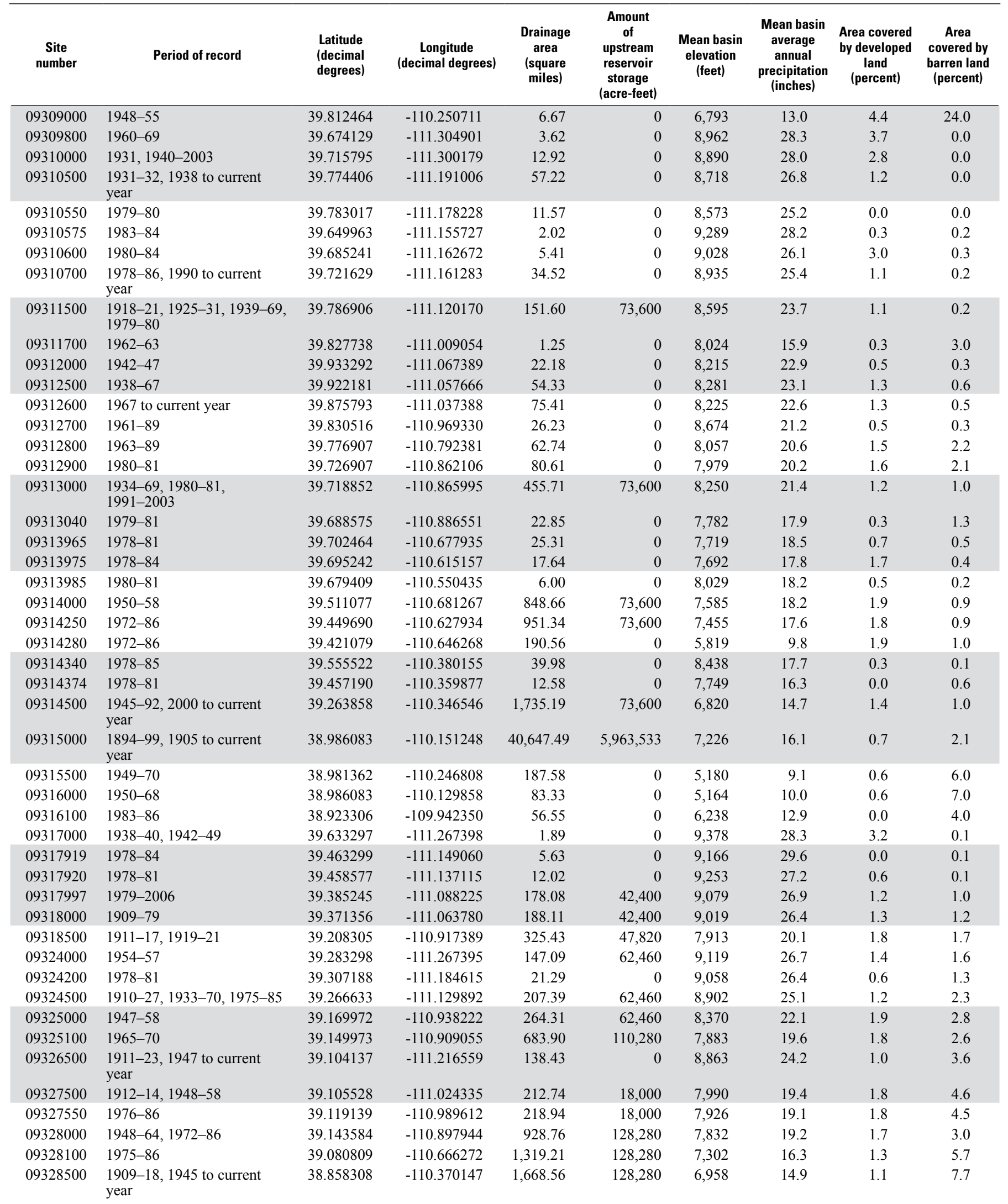




\begin{tabular}{|c|c|c|c|c|c|c|c|c|c|c|c|}
\hline $\begin{array}{c}\text { Area } \\
\text { covered by } \\
\text { deciduous } \\
\text { forest } \\
\text { (percent) }\end{array}$ & $\begin{array}{c}\text { Area } \\
\text { covered by } \\
\text { evergreen } \\
\text { forest } \\
\text { (percent) }\end{array}$ & $\begin{array}{c}\text { Area } \\
\text { covered by } \\
\text { mixed forest } \\
\text { (percent) }\end{array}$ & $\begin{array}{c}\text { Area } \\
\text { covered } \\
\text { by shrubs } \\
\text { young or } \\
\text { stunted trees } \\
\text { (percent) }\end{array}$ & $\begin{array}{c}\text { Area } \\
\text { covered } \\
\text { by grass or } \\
\text { herbaceous } \\
\text { land } \\
\text { (percent) }\end{array}$ & $\begin{array}{c}\text { Sedimentary, } \\
\text { clastic } \\
\text { lithology, } \\
\text { Mesozoic } \\
\text { (percent) }\end{array}$ & $\begin{array}{c}\text { Sedimentary, } \\
\text { clastic } \\
\text { (continental) } \\
\text { lithology, } \\
\text { Tertiary } \\
\text { (percent) }\end{array}$ & $\begin{array}{c}\text { Igneous or } \\
\text { metamorphic } \\
\text { lithologies } \\
\text { (percent) }\end{array}$ & $\begin{array}{c}\text { Sedimentary, } \\
\text { mixed } \\
\text { (continental } \\
\text { and marine) } \\
\text { lithology } \\
\text { (percent) }\end{array}$ & $\begin{array}{c}\text { Sedimentary, } \\
\text { carbonate } \\
\text { (marine) } \\
\text { lithology } \\
\text { (percent) }\end{array}$ & $\begin{array}{l}\text { Population } \\
\text { density } \\
\text { (people per } \\
\text { square mile) }\end{array}$ & $\begin{array}{l}\text { Road density } \\
\text { (miles per } \\
\text { square mile) }\end{array}$ \\
\hline 0.0 & 14.0 & 0.0 & 57.5 & 0.0 & 0.0 & 100.0 & 0.0 & 0.0 & 0.0 & 0.08 & 2.05 \\
\hline 42.6 & 2.8 & 2.3 & 47.5 & 0.2 & 1.3 & 98.7 & 0.0 & 0.0 & 0.0 & 0.97 & 4.80 \\
\hline 42.2 & 6.2 & 1.5 & 46.0 & 0.3 & 17.7 & 82.3 & 0.0 & 0.0 & 0.0 & 0.97 & 4.27 \\
\hline 59.5 & 18.9 & 0.6 & 20.8 & 0.1 & 75.4 & 24.5 & 0.0 & 0.0 & 0.0 & 0.41 & 2.20 \\
\hline 40.6 & 43.2 & 4.1 & 11.0 & 0.6 & 100.0 & 0.0 & 0.0 & 0.0 & 0.0 & 0.62 & 3.68 \\
\hline 42.0 & 37.8 & 6.7 & 10.1 & 0.1 & 100.0 & 0.0 & 0.0 & 0.0 & 0.0 & 0.62 & 2.59 \\
\hline 43.7 & 38.9 & 4.8 & 11.0 & 0.3 & 100.0 & 0.0 & 0.0 & 0.0 & 0.0 & 0.62 & 2.59 \\
\hline 43.4 & 19.5 & 2.4 & 30.4 & 0.4 & 71.1 & 28.9 & 0.0 & 0.0 & 0.0 & 0.64 & 2.69 \\
\hline 39.1 & 22.6 & 6.5 & 30.5 & 0.5 & 82.5 & 17.5 & 0.0 & 0.0 & 0.0 & 0.60 & 2.90 \\
\hline 11.5 & 22.4 & 1.5 & 60.8 & 0.0 & 0.0 & 100.0 & 0.0 & 0.0 & 0.0 & 0.43 & 1.26 \\
\hline 12.4 & 29.3 & 1.4 & 53.3 & 0.0 & 7.1 & 92.9 & 0.0 & 0.0 & 0.0 & 0.53 & 1.30 \\
\hline 29.2 & 24.2 & 2.2 & 41.2 & 0.2 & 33.7 & 66.3 & 0.0 & 0.0 & 0.0 & 0.44 & 2.30 \\
\hline 31.7 & 53.2 & 1.9 & 11.5 & 0.0 & 88.4 & 11.6 & 0.0 & 0.0 & 0.0 & 0.62 & 1.54 \\
\hline 20.3 & 24.3 & 0.5 & 53.7 & 0.0 & 11.1 & 88.9 & 0.0 & 0.0 & 0.0 & 0.97 & 1.54 \\
\hline 13.4 & 38.0 & 1.2 & 45.4 & 0.0 & 10.1 & 89.9 & 0.0 & 0.0 & 0.0 & 0.72 & 2.09 \\
\hline 20.4 & 52.6 & 2.2 & 24.2 & 0.0 & 22.7 & 77.3 & 0.0 & 0.0 & 0.0 & 0.42 & 2.35 \\
\hline 20.2 & 25.5 & 1.5 & 46.9 & 0.5 & 57.1 & 42.9 & 0.0 & 0.0 & 0.0 & 3.10 & 2.35 \\
\hline 18.2 & 24.7 & 1.4 & 49.0 & 0.7 & 61.2 & 38.8 & 0.0 & 0.0 & 0.0 & 2.91 & 2.32 \\
\hline 0.0 & 2.9 & 0.0 & 70.8 & 7.7 & 73.9 & 26.1 & 0.0 & 0.0 & 0.0 & 0.52 & 1.82 \\
\hline 2.2 & 41.7 & 0.0 & 51.0 & 0.5 & 63.1 & 36.9 & 0.0 & 0.0 & 0.0 & 0.08 & 0.53 \\
\hline 34.2 & 15.8 & 2.0 & 43.6 & 1.0 & 7.2 & 92.8 & 0.0 & 0.0 & 0.0 & 1.01 & 2.66 \\
\hline 39.5 & 45.0 & 6.4 & 8.7 & 0.1 & 66.3 & 33.7 & 0.0 & 0.0 & 0.0 & 0.54 & 0.17 \\
\hline 42.7 & 31.8 & 11.7 & 11.7 & 1.4 & 39.0 & 61.0 & 0.0 & 0.0 & 0.0 & 0.54 & 1.77 \\
\hline 31.4 & 44.3 & 6.1 & 14.6 & 0.6 & 65.7 & 28.0 & 0.0 & 6.3 & 0.0 & 0.72 & 1.52 \\
\hline 30.2 & 44.3 & 6.0 & 15.5 & 0.6 & 65.1 & 28.9 & 0.0 & 5.9 & 0.0 & 0.70 & 1.60 \\
\hline 17.8 & 31.9 & 3.6 & 34.0 & 2.2 & 72.0 & 24.5 & 0.0 & 3.4 & 0.0 & 1.71 & 1.72 \\
\hline 16.3 & 38.5 & 5.8 & 24.6 & 10.5 & 15.4 & 75.1 & 0.0 & 9.4 & 0.0 & 0.46 & 1.49 \\
\hline 20.9 & 50.9 & 5.6 & 20.6 & 0.0 & 47.3 & 52.7 & 0.0 & 0.0 & 0.0 & 0.33 & 1.72 \\
\hline 14.0 & 39.5 & 5.0 & 29.1 & 7.8 & 26.9 & 66.4 & 0.0 & 6.7 & 0.0 & 0.42 & 1.40 \\
\hline 11.3 & 33.0 & 4.1 & 35.0 & 6.9 & 38.0 & 56.7 & 0.0 & 5.2 & 0.0 & 1.96 & 1.67 \\
\hline 12.9 & 29.0 & 3.3 & 39.5 & 4.3 & 60.3 & 36.0 & 0.0 & 3.7 & 0.0 & 1.70 & 1.69 \\
\hline 12.0 & 35.4 & 6.9 & 35.1 & 5.7 & 25.6 & 65.0 & 0.0 & 9.4 & 0.0 & 0.68 & 1.29 \\
\hline 7.9 & 25.4 & 4.5 & 41.3 & 7.9 & 42.4 & 51.5 & 0.0 & 6.1 & 0.0 & 0.81 & 1.56 \\
\hline 7.7 & 24.7 & 4.4 & 42.2 & 8.0 & 43.6 & 50.5 & 0.0 & 5.9 & 0.0 & 0.80 & 1.55 \\
\hline 11.3 & 27.2 & 3.5 & 41.3 & 5.2 & 57.5 & 38.5 & 0.0 & 4.1 & 0.0 & 1.44 & 1.65 \\
\hline 8.0 & 19.6 & 2.4 & 49.5 & 8.3 & 68.1 & 29.0 & 0.0 & 2.9 & 0.0 & 1.06 & 1.51 \\
\hline 6.3 & 16.1 & 1.9 & 52.5 & 10.1 & 70.5 & 24.7 & 0.0 & 4.3 & 0.5 & 0.85 & 1.45 \\
\hline
\end{tabular}


Appendix 1-1. Watershed characteristics for the U.S. Geological Survey streamgage network in the Upper Colorado River Basin.-Continued

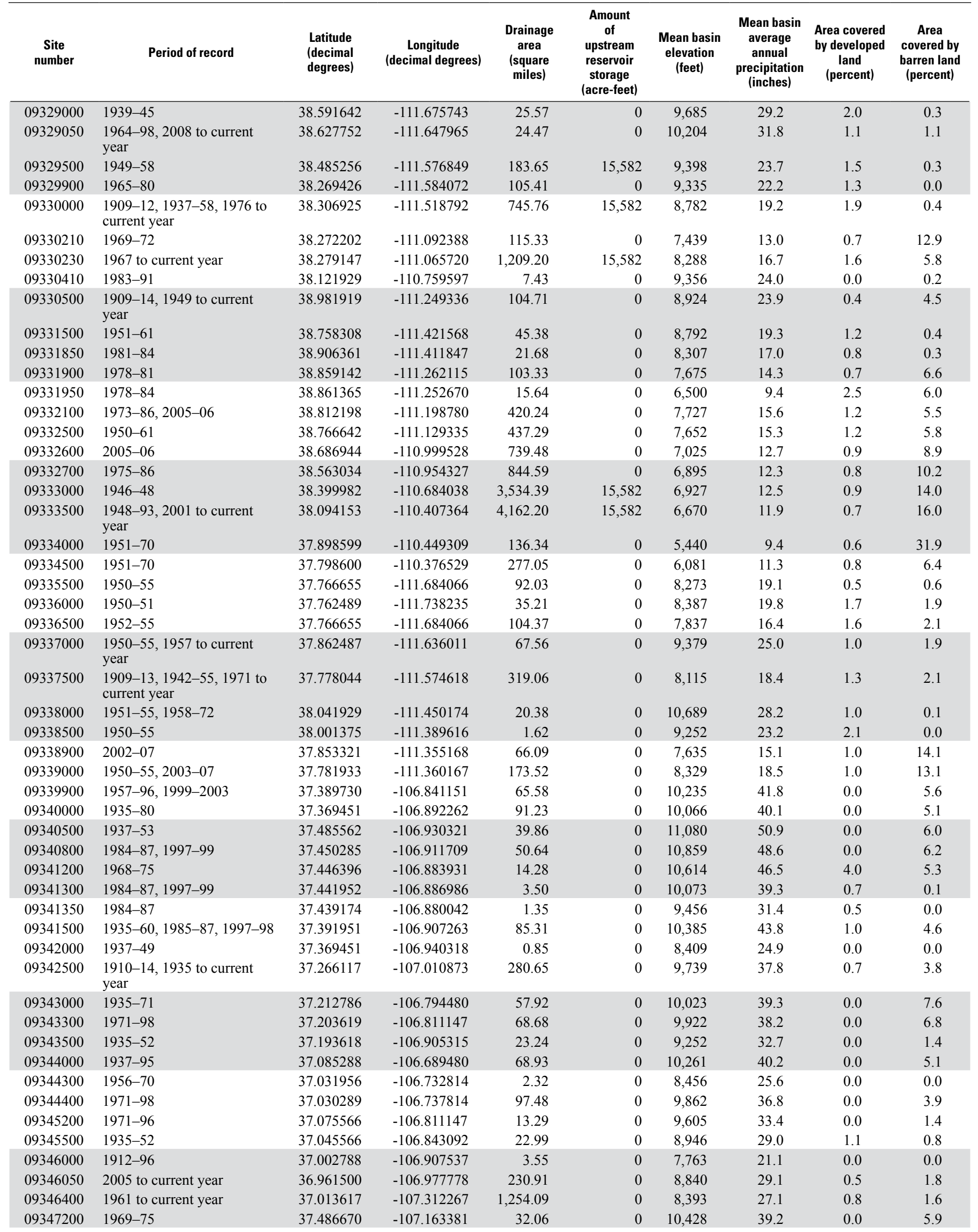




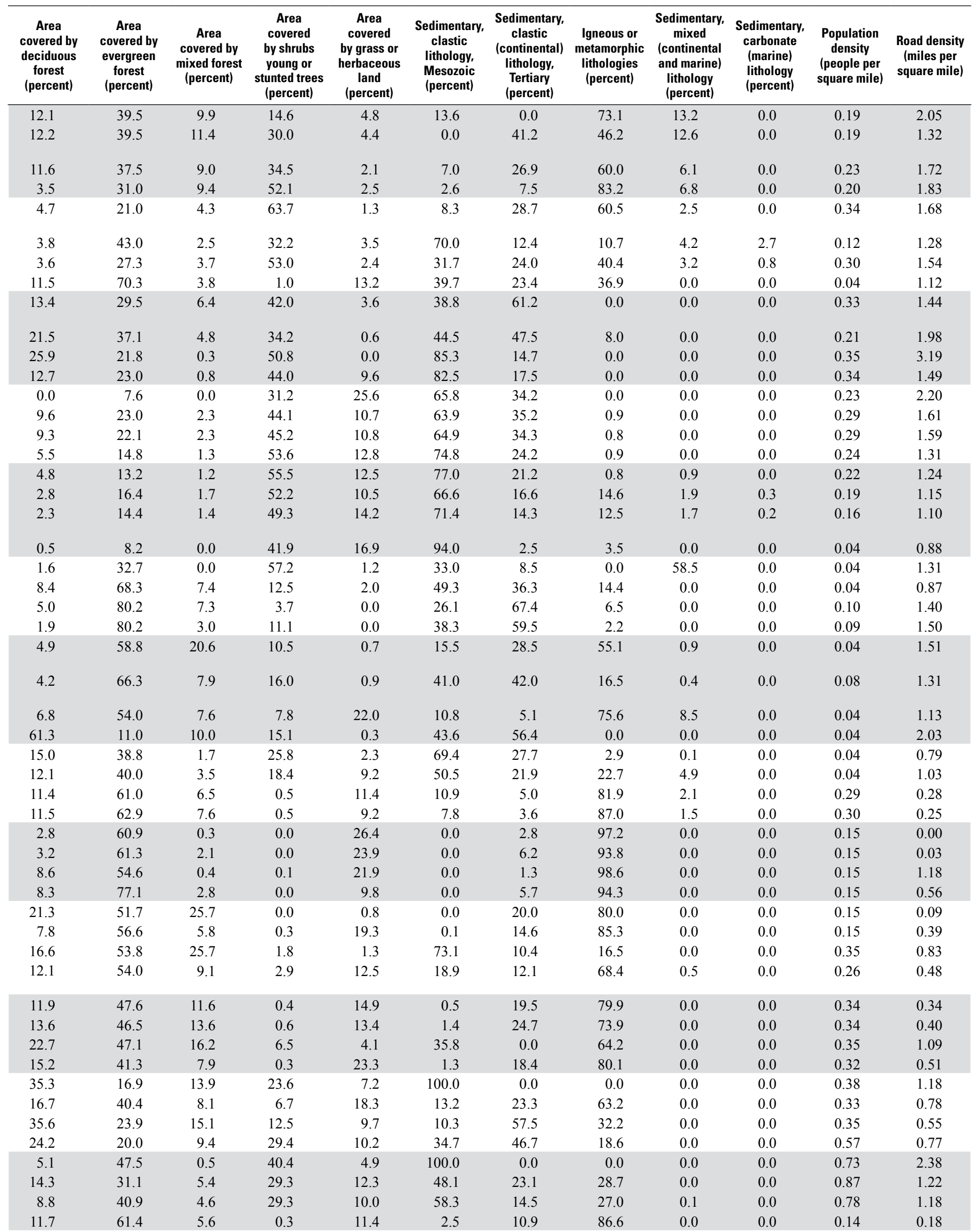


Appendix 1-1. Watershed characteristics for the U.S. Geological Survey streamgage network in the Upper Colorado River Basin.-Continued

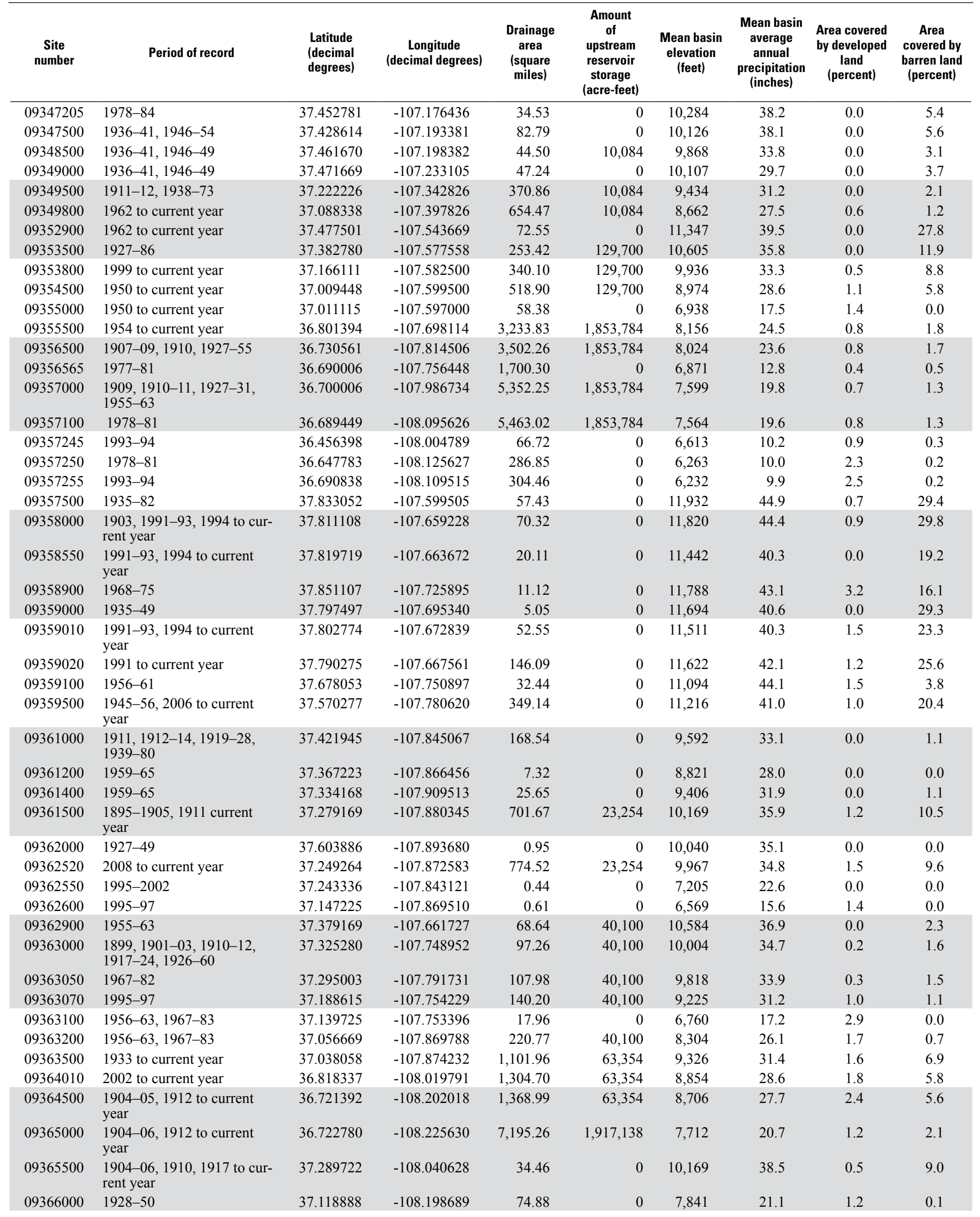




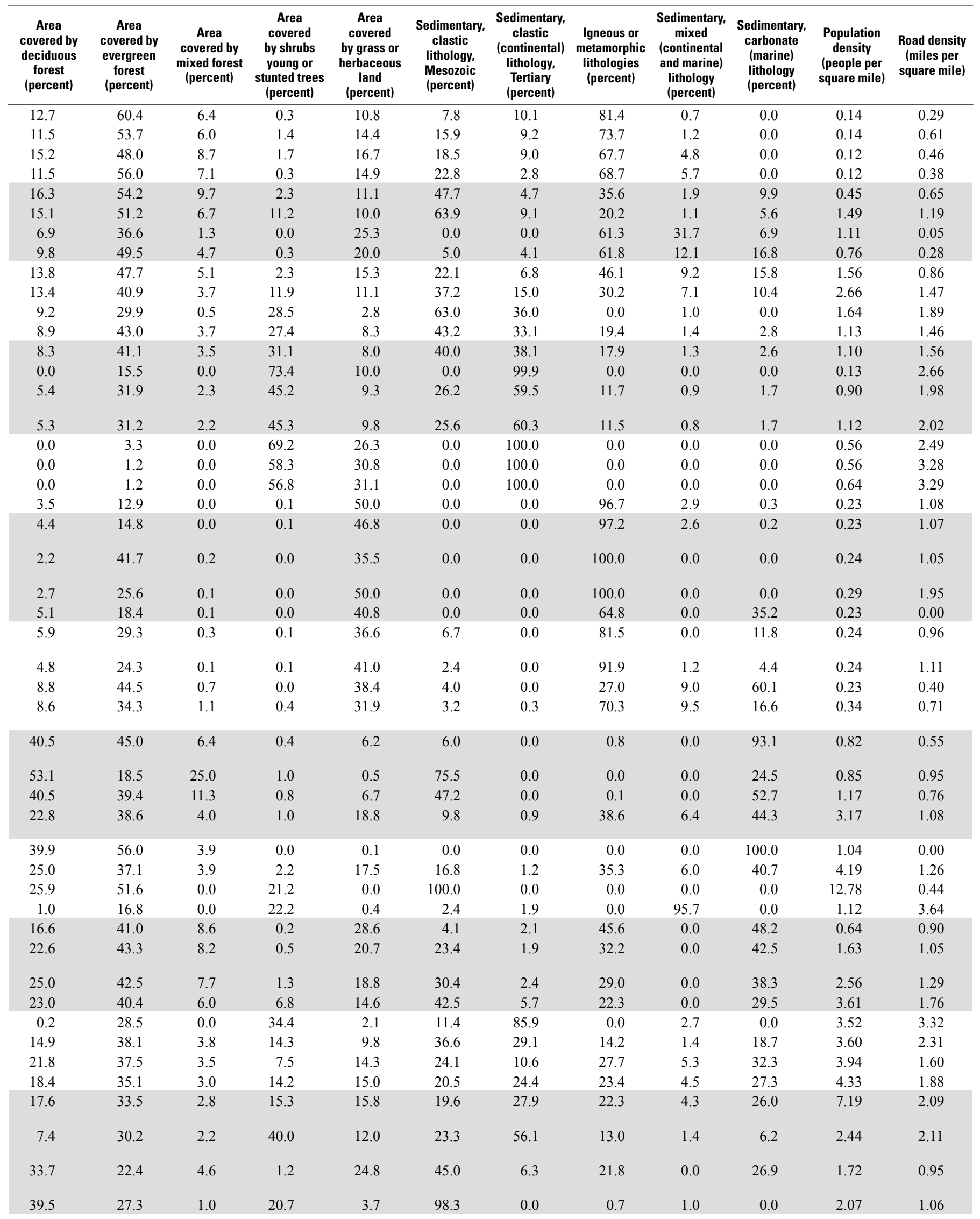


Appendix 1-1. Watershed characteristics for the U.S. Geological Survey streamgage network in the Upper Colorado River Basin.-Continued

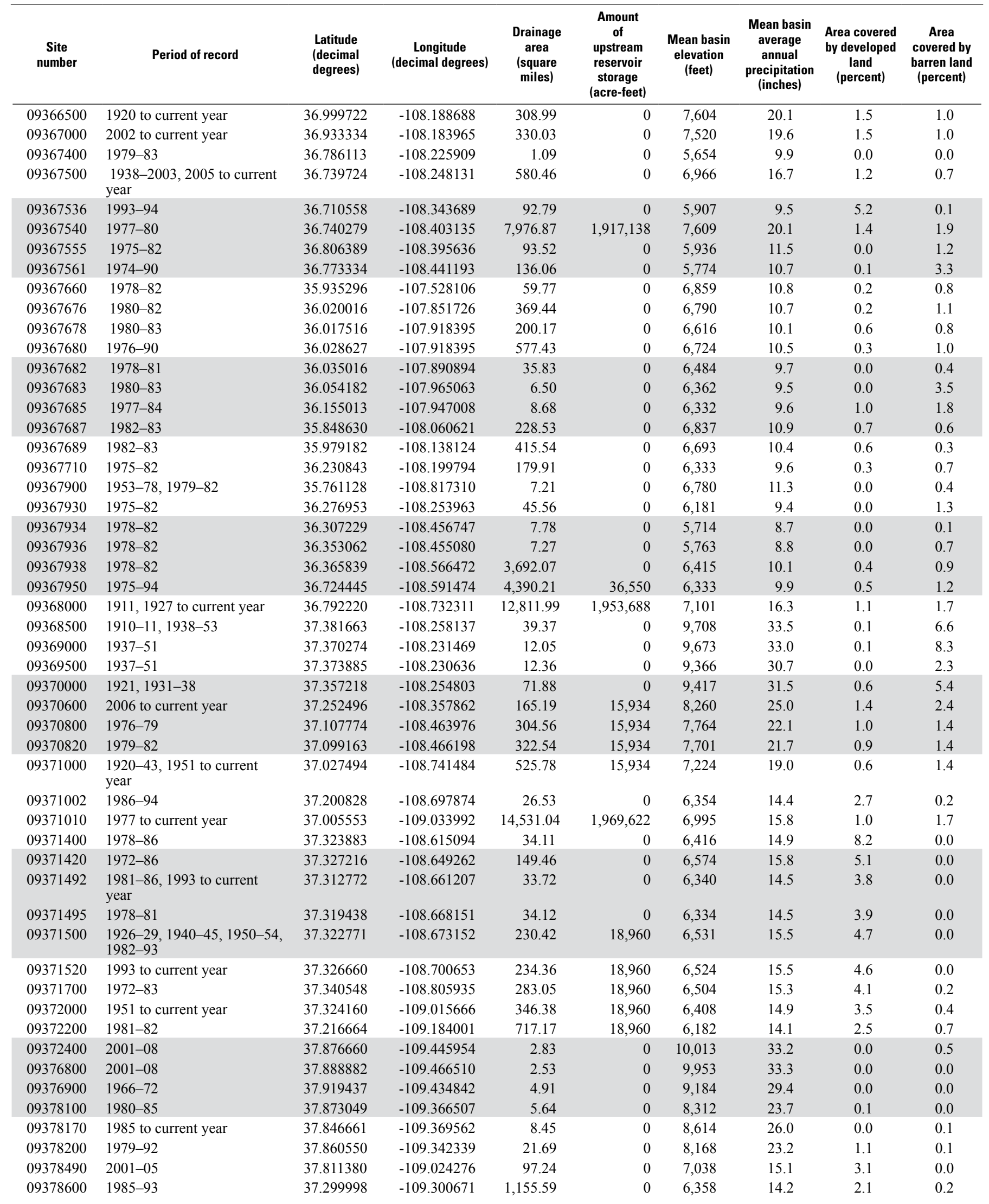




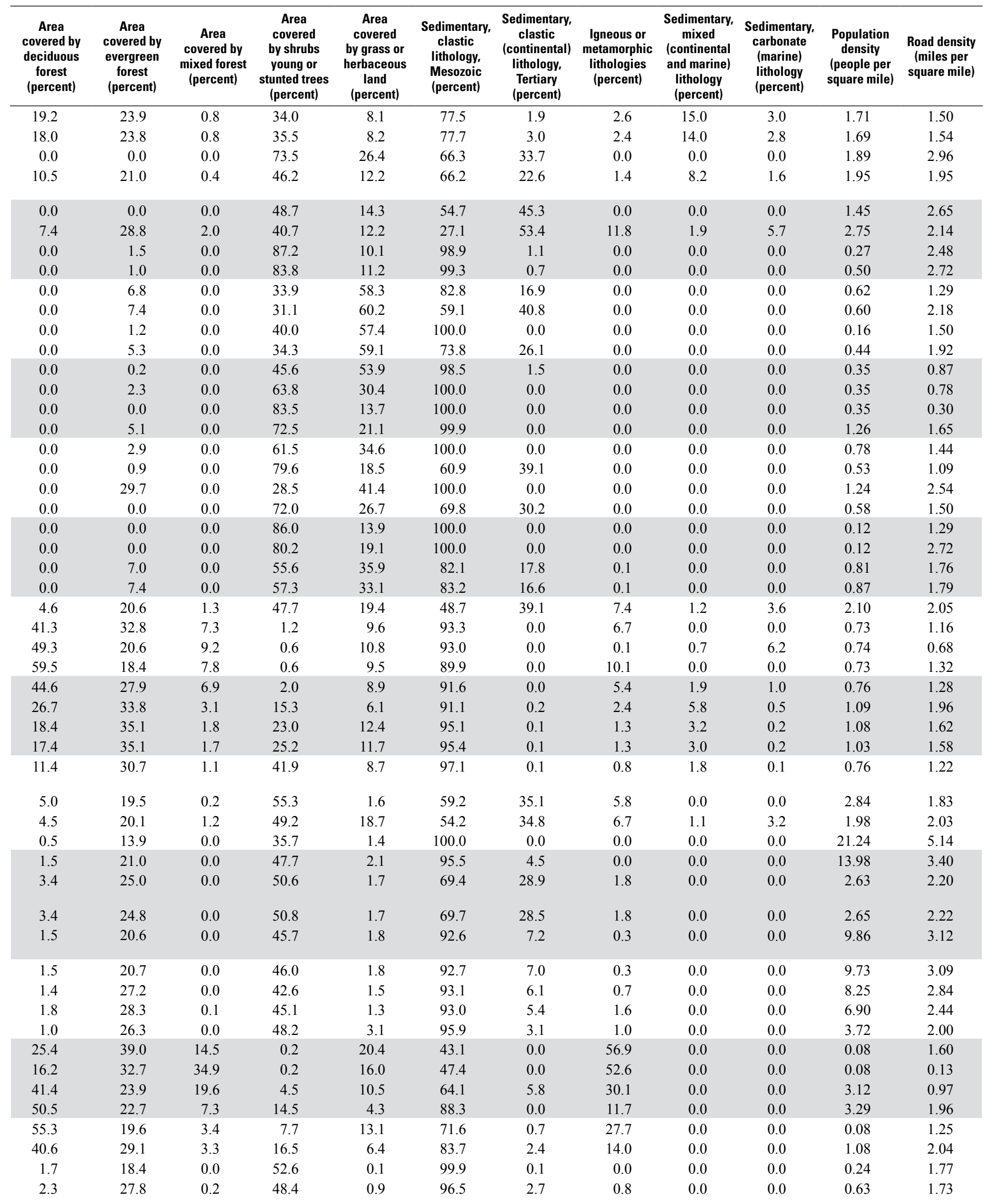


Appendix 1-1. Watershed characteristics for the U.S. Geological Survey streamgage network in the Upper Colorado River Basin.-Continued

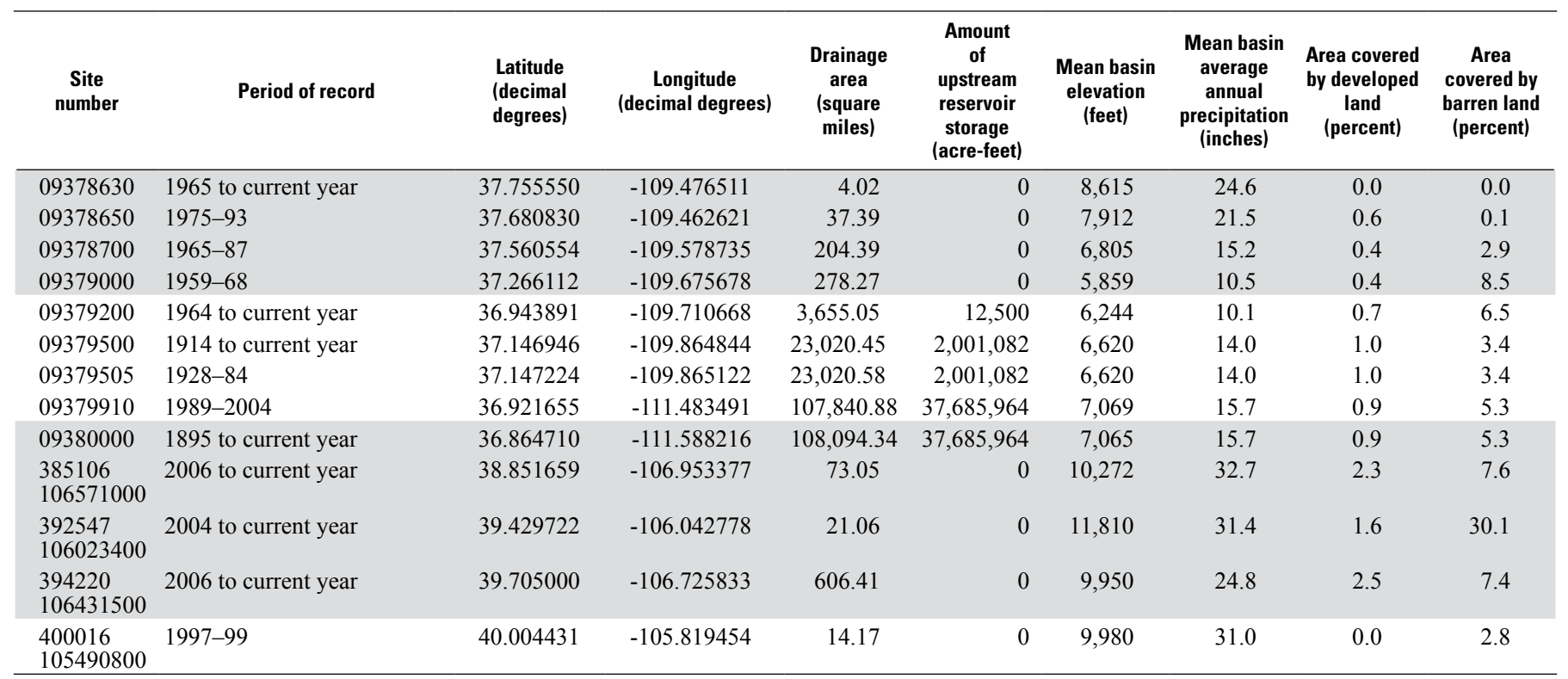




\begin{tabular}{|c|c|c|c|c|c|c|c|c|c|c|c|}
\hline $\begin{array}{c}\text { Area } \\
\text { covered by } \\
\text { deciduous } \\
\text { forest } \\
\text { (percent) }\end{array}$ & $\begin{array}{c}\text { Area } \\
\text { covered by } \\
\text { evergreen } \\
\text { forest } \\
\text { (percent) }\end{array}$ & $\begin{array}{c}\text { Area } \\
\text { covered by } \\
\text { mixed forest } \\
\text { (percent) }\end{array}$ & $\begin{array}{c}\text { Area } \\
\text { covered } \\
\text { by shrubs } \\
\text { young or } \\
\text { stunted trees } \\
\text { (percent) }\end{array}$ & $\begin{array}{c}\text { Area } \\
\text { covered } \\
\text { by grass or } \\
\text { herbaceous } \\
\text { land } \\
\text { (percent) }\end{array}$ & $\begin{array}{c}\text { Sedimentary, } \\
\text { clastic } \\
\text { lithology, } \\
\text { Mesozoic } \\
\text { (percent) }\end{array}$ & $\begin{array}{c}\text { Sedimentary, } \\
\text { clastic } \\
\text { (continental) } \\
\text { lithology, } \\
\text { Tertiary } \\
\text { (percent) }\end{array}$ & $\begin{array}{l}\text { Igneous or } \\
\text { metamorphic } \\
\text { lithologies } \\
\text { (percent) }\end{array}$ & $\begin{array}{c}\text { Sedimentary, } \\
\text { mixed } \\
\text { (continental } \\
\text { and marine) } \\
\text { lithology } \\
\text { (percent) }\end{array}$ & $\begin{array}{c}\text { Sedimentary, } \\
\text { carbonate } \\
\text { (marine) } \\
\text { lithology } \\
\text { (percent) }\end{array}$ & $\begin{array}{l}\text { Population } \\
\text { density } \\
\text { (people per } \\
\text { square mile) }\end{array}$ & $\begin{array}{l}\text { Road density } \\
\text { (miles per } \\
\text { square mile) }\end{array}$ \\
\hline 48.7 & 38.5 & 2.1 & 0.4 & 10.1 & 80.7 & 0.0 & 19.3 & 0.0 & 0.0 & 0.06 & 1.62 \\
\hline 38.0 & 43.1 & 1.7 & 7.4 & 6.0 & 90.5 & 0.7 & 8.3 & 0.5 & 0.0 & 0.56 & 1.85 \\
\hline 11.0 & 55.6 & 0.1 & 26.0 & 1.0 & 81.6 & 6.6 & 0.6 & 10.6 & 0.5 & 0.04 & 1.49 \\
\hline 2.4 & 29.2 & 0.0 & 56.6 & 1.5 & 9.1 & 1.6 & 0.0 & 88.0 & 1.2 & 0.04 & 0.94 \\
\hline 0.1 & 18.9 & 0.0 & 57.9 & 15.3 & 92.1 & 5.2 & 0.4 & 2.3 & 0.0 & 1.33 & 2.28 \\
\hline 3.2 & 19.3 & 0.7 & 51.6 & 16.6 & 65.8 & 23.6 & 4.5 & 3.7 & 2.4 & 1.68 & 2.04 \\
\hline 3.2 & 19.3 & 0.7 & 51.6 & 16.6 & 65.8 & 23.6 & 4.5 & 3.7 & 2.4 & 1.68 & 2.04 \\
\hline 7.4 & 21.6 & 0.8 & 50.2 & 9.4 & 46.4 & 35.2 & 9.0 & 5.5 & 3.9 & 1.11 & 1.47 \\
\hline 7.4 & 21.5 & 0.8 & 50.2 & 9.4 & 46.5 & 35.2 & 8.9 & 5.5 & 3.9 & 1.11 & 1.47 \\
\hline 18.2 & 34.9 & 0.4 & 1.5 & 27.9 & 63.8 & 8.6 & 27.6 & 0.0 & 0.0 & 4.45 & 2.29 \\
\hline 1.2 & 33.1 & 0.0 & 0.0 & 24.6 & 0.0 & 0.0 & 65.9 & 0.0 & 34.0 & 3.73 & 2.29 \\
\hline 16.6 & 40.3 & 1.9 & 13.7 & 14.3 & 11.5 & 5.3 & 38.9 & 1.8 & 42.4 & 5.33 & 1.78 \\
\hline 0.2 & 85.6 & 0.0 & 0.0 & 3.9 & 0.0 & 0.0 & 100.0 & 0.0 & 0.0 & 1.51 & 1.87 \\
\hline
\end{tabular}




